BALKÁNYI PÉTER TAMÁS

AZ E-LEARNING TANANYAGFEJLESZTÉS ÖKOSZISZTÉMÁJÁNAK DESIGN SCIENCE MÓDSZERTAN SZERINTI VIZSGÁLATA 


\section{INFOKOMMUNIKÁCIÓS TANSZÉK}

Témavezető: Nemeslaki András, PhD

(C) Balkányi Péter Tamás 


\section{BUDAPESTI CORVINUS EGYETEM}

GAZDASÁGINFORMATIKA DOKTORI ISKOLA

\section{AZ E-LEARNING TANANYAGFEJLESZTÉS ÖKOSZISZTÉMÁJÁNAK DESIGN SCIENCE MÓDSZERTAN SZERINTI VIZSGÁLATA}

Doktori értekezés

Balkányi Péter Tamás

Budapest, 2019 



\section{TARTALOMJEGYZÉK}

\section{BEVEZETÉS - PROBLÉMÁK FELVETÉSE, KUTATÁSI CÉLOK ÉS A dOLGOZAT FELÉPÍTÉSE 1}

1.1 PROBLÉMAFELVETÉS - VEZETŐKÉNT HELYT ÁLLNI A GYORSAN VÁLTOZÓ JOGI, TECHNIKAI, SZERVEZETI ERÖFORRÁS KÖRNYEZETBEN 1

1.2 KUTATÁSI CÉLOK AZONOSÍTÁSA - SZISZTEMATIKUS VÁLASZ A MEGOLDANDÓ PROBLÉMÁKRA A DIGITÁLIS TANANYAGOK FEJLESZTÉSÉN KERESZTÜL, AZ ÜZLETI ÖKOSZISZTÉMA KERETRENDSZERÉBEN 5

1.3 KUTATÁSI KÉRDÉSEK - A PROBLÉMAKÖRÖK ÁTTEKINTÉSE …………………………........... 8

1.4 A KUTATÁS ÉS A DOLGOZAT FELÉPÍTÉSE - RÖVIDEN A KUTATÁS KERETEIRÖL ÉS SZERKEZETÉRÖL

1.4.1 Dolgozat szerkezete, felépitése, tagolása - röviden az útról ........................................ 9

1.4.2 Az alkalmazott módszertani elemekröl - kutatási keret és kutatási stratégiák választásának okai és háttere

1.4.3 A dolgozat konkrét kutatás módszertani kereteinek meghatározása - a kutatás felépitése

1.5 DESIGN SCIENCE - AZ ALAPOK ISMERTETÉS ÉS A DISSZERTÁCIÓBAN ALKALMAZOTT SZEMPONTOK KIFEJTÉSE

1.5.1 Általánosan a Design elméletekröl - történeti háttér és a megoldhatatlan problémák 16

1.5.2 A kutatás szigora-módszertani kihivások, kritika és a legfontosabb szempontok...... 18

1.5.3 A kutatások csoportositása - avagy mi lehet ebböl az egészböl? ............................... 19

1.6 AKCIÓKUTATÁS ÉS ESETTANULMÁNY - A DISSZERTÁCIÓ HÁTTERÉBEN „MEGHÚZÓDÓ”

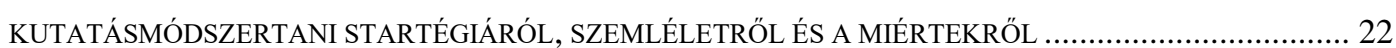

1.6.1 Részletesen az akciókutatási stratégiáról - cél a problémák megoldása .................... 22

1.6.2 Az esettanulmány kutatási stratégiáról - cél a problémák mély megismerése .............. 24

1.7 HÁROMSZÖGELŐ VIZSGÁLATOK - RÖVIDEN A DOLGOZAT ÉRVÉNYESSÉGÉVEL KAPCSOLATOSAN

1.8 KUTATÁSI KÉRDÉSEK - RELEVANCIA, CSOPORTOSÍTÁS ÉS AZ ADATOK AZONOSÍTÁSA.............. 27

1.9 HIPOTÉZISEK - SEJTÉSEK ÉS ELVÁRÁSOK ………….......................................................... 29

2 IRODALOMFELDOLGOZÁS, ELMÉLETI HÁTTÉR - ALAPVETŐ TERÜLETEK,

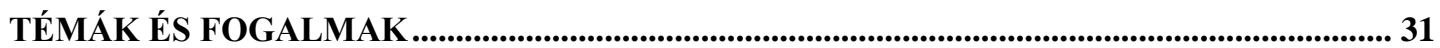

2.1 E-LEARNING „FOGALOMTÁR” - KUTATÁSHOZ NÉLKÜLÖZHETETLEN FOGALMAK

MAGYARÁZATA ÉS A SZAKSZAVAK ÖSSZEFOGLALÁSA ………................................................ 31

2.1.1 A ,tanuló- és tartalomközpontú" e-learning tananyag meghatározása-amiért érdemes dolgozni .............................................................................................................. 38

2.1.2 A tananyagok értékelési rendszere - szintek és keretek az értékelésekhez ................... 41

2.2 AZ E-LEARNING TÁRSTERÜLETEK AZONOSÍTÁSA ÉS ELEMZÉSE - AZ ÉRINTETT TERÜLETEK

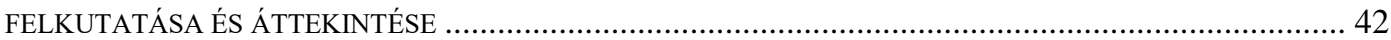

2.2.1 Az e-learning társterületeinek azonositása - a feltárás szövegelemzéses vizsgálata ... 42 
2.2.2 Kitekintés a társterületekre - a tágabb tudományos környezet összefoglalása

\section{KUTATÁS - A PROBLÉMÁK FELTÁRÁSA, A MEGOLdÁSI FOLYAMAT DEFINIÁLÁSA, MAJD AZ EREDMÉNYEK ÉRTÉKELÉSE ..................................................... 56}

3.1 A KUTATÁS HÁTTERÉNEK BEMUTATÁSA - A HAT FEJLESZTÉSI PROJEKT ADATLAPJAI ÉS A PROJEKTEK ÖSSZEFOGLALÁSA......

3.1.1 Irodai programokhoz tananyagok fejlesztése - a kezdeti ismerkedés a gyártási

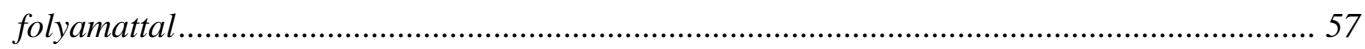

3.1.2 Jogszabályok és szervezetek ismertetése - egy speciális terület megismerése ............. 58

3.1.3 Továbbképzési rendszer - komplex és egyedi fejlesztési folyamat............................. 59

3.1.4 Közszféra szervezete számára szakmai tananyagok-szemléletformálás és játékos tartalom .

3.1.5 Területspecifikus alap-és termékismeretek átadása-tantermi képzés átalakitása, kiváltása......

3.1.6 Készségfejlesztö tananyagok-egyénre szabott nagyvállalati tananyagok 62

3.2 PROBLÉMÁK AZONOSÍTÁSA - A KUTATÁS ÁLTAL MEGVIZSGÁLNI KÍVÁNT TERÜLET PROBLÉMATÉRKÉPÉNEK FELRAJZOLÁSA

3.2.1 Gyakorlat és tudás - a problémafeltárás és bemutatása.. 63

3.2.2 Gondolattérkép technika - a megfigyelések és mélyinterjúk eredményeinek összegzése.

3.3 MEGOLDÁS KONSTRUÁLÁSA - (1.) A TANANYAGFEJLESZTÉSI FOLYAMAT FELÉPÍTÉSE, (2.) A TERMÉK, (3.) KAPCSOLÓDÓ SZEREPEK ÉS (4.) ESZKÖZÖK BEMUTATÁSA 70

3.3.1 Az öt-ciklus (5C) tananyagfejlesztés folyamata - Egy közel évtizedes kutatás eredménye 71

3.3.2 Termékek és tananyagtípus termékek összefoglalása - a fejlesztések ,,kézzelfogható”

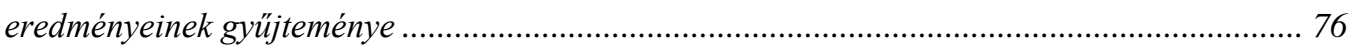

3.3.3 A fejlesztés kulcsszereplői - résztvevők és szerepek ............................................... 80

3.3.4 A fejlesztés eszközei és kapcsolódó technológiák-mivel készítünk e-learning tananyagokat?

3.4 PROJEKTEK ÖSSZEFOGLALÁSA ÉS ÉRTÉKELÉSE - AZ E-LEARNING ÖKOSZISZTÉMA TÜKRÉBEN....

3.4.1 Területspecifikus alap-és termékismeretek e-learning tananyag visszajelzéseinek vizsgálata - szövegbányászati kutatási elem ................................................................... 92

3.4.2 Projektek összefoglalás - szintetizálás és összekapcsolás..................................... 100

3.4.3 Projektek értékelése - a fejlesztésekkel kapcsolatos közvetlen és közvetett megfigyelések, visszajelzések elemzése 103

3.5 GYAKORLATI EREDMÉNYEK ÖSSZEFOGLALÁSA - AZ E-LEARNING BY DESIGN SZEMLÉLET ÉS AZ E-LEARNING TANANYAGFEJLESZTÉS VÍZIÓJA 106

3.5.1 „E-learning by design” - szemléletmód az e-learning fejlesztésekhez ..................... 106

3.5.2 Következtetések és alapvetések - egy e-learning vizió ............................................... 108 


\section{A KUTATÁS ÉRTÉKELÉSE ÉS A TUDOMÁNYOS EREDMÉNYEK -}

KÖVETKEZTETÉSEK ÉS KITEKINTÉS................................................................................... 111

4.1 A KUTATÁS ÉRTÉKELÉSE - DESIGN SCIENCE SZEMLÉLET ALAPJÁN A KUTATÁSRÓL ............... 111

4.2 A DISSZERTÁCIÓ TUDOMÁNYOS EREDMÉNYEINEK, TÉZISEINEK ÖSSZEFOGLALÁSA-

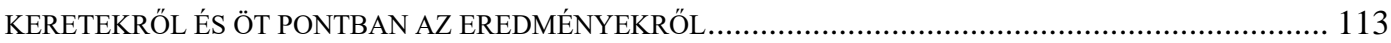

5 IRODALOMJEGYZÉK ………..................................................................................................... 116

6 MELLÉKLETEK................................................................................................................................. 137

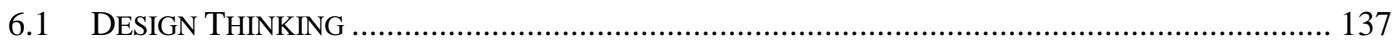

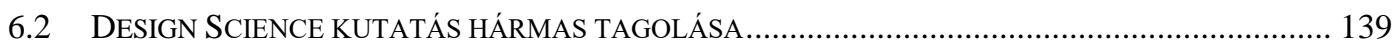

6.3 A DESIGN SCIENCE KUTATÁS HÁRMAS KUTATÁSI CIKLUSA ÉS ELLENŐRZŐ LISTÁJA ............. 140

6.4 AZ ACTION RESEARCH ÉS A CASE STUDY STRATÉGIÁK ÖSSZEHASONLÍTÁSA .......................... 142

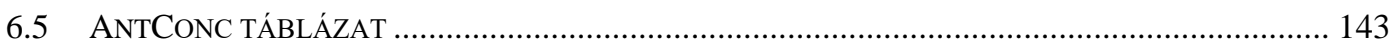

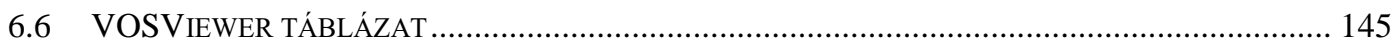

6.7 KUTATÁSBA BEVONT PROJEKTEK RÉSZLETES BEMUTATÁSA.................................................. 148

6.7.1 Irodai programokhoz tananyagok fejlesztése ........................................................... 149

6.7.2 Jogszabályok és szervezetek ismertetése ……………………………………….... 150

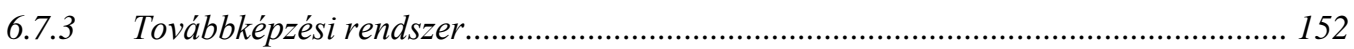

6.7.4 Közszféra szervezete számára szakmai és szemléletformáló tananyagai ................... 154

6.7.5 Területspecifikus alap- és termékismeretek átadása ................................................ 155

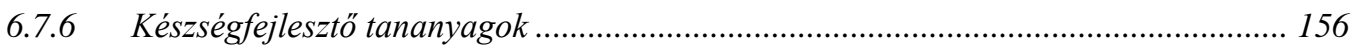

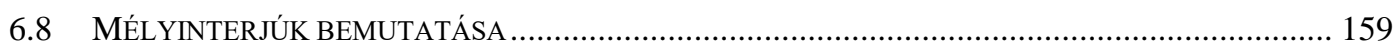

6.9 TANANYAGFEJLESZTÉS FOLYAMATÁNAK RÉSZEI RÉSZLETESEN …….................................. 161

6.10 TANANYAGFEJLESZTŐ ESZKÖZÖKRÖL RÉSZLETESEN ……................................................ 167

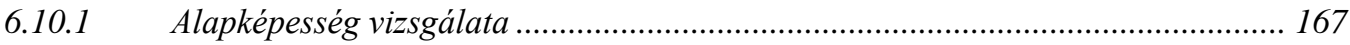

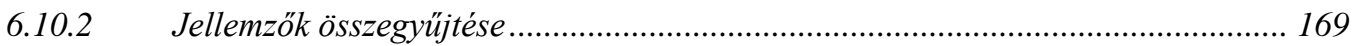

6.10.3 Tesztelés és kipróbálás ............................................................................... 170

6.10.4 Döntés ................................................................................................... 172

6.10.5 Tananyagfejlesztő szoftverek értékeléséhez iránymutatás ................................... 172

6.10.6 Tananyagfejlesztö szoftverek adatlapjai ........................................................ 174

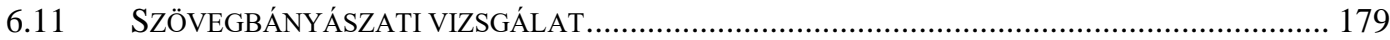

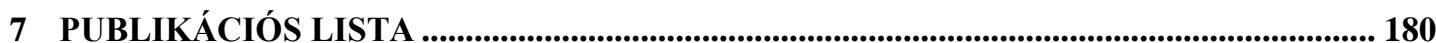




\section{ÁBRAJEGYZÉK}

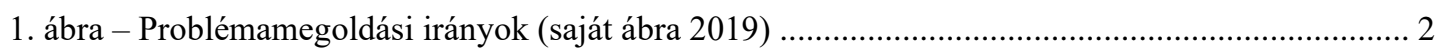

2. ábra - Kutatási területek és témák azonosítása (saját ábra 2018) ……………………................... 7

3. ábra - Kutatásmódszertani összefoglalás (saját ábra 2019) ............................................................. 11

4. ábra - DSR kutatás felépítése (Offermann és mtsai. 2009) alapján (saját ábra 2018)...................... 13

5. ábra - DSR tudáshozzájárulás keretrendszer (Vaishnavi és Kuechler, 2004) alapján (saját ábra 2018)

6. ábra - A kutatási kérdések (KKn) DSR kategóriák szerinti ábrázolása (saját ábra 2019)................ 27

7. ábra - Társterületek felkutatása, módszertani összefoglaló (saját ábra 2019) ………....................... 43

8. ábra - Hasonlósági kiszámítása (van Eck és Waltman, 2010) …………………………………....... 44

9. ábra - E-learning tananyagfejlesztéssel kapcsolatos publikációk kulcsszavai (forrás: VOSViewer 2019) .45

10. ábra - Keresőkifejezések összehasonlítása (Google Trends, 2019) …………………………..... 50

11. ábra - A kutatásba bevont e-learning tananyagfejlesztések idővonala (saját ábra 2018) ................ 56

12. ábra - Problémák beágyazott feltárása (Wieringa, 2009) alapján (saját ábra 2019)........................ 64

13. ábra - Szervezetfejlesztési és működtetési problématérkép (saját ábra 2019) ………………....... 65

14. ábra - E-learning tananyagfejlesztés ökoszisztéma (saját ábra 2019) ............................................. 70

15. ábra - E-learning tananyagfejlesztés folyamata és belső ciklusai (saját ábra 2019) ........................ 74

16. ábra - Kulcsszereplők bemutatása és hatásuk (saját ábra 2019) ………………………............... 81

17. ábra - Résztvevők elemzése Newcomb (2003) nyomán (saját ábra 2019) .................................... 85

18. ábra - E-learning fejlesztő eszközök összehasonlítása (saját ábra 2018) ……………………….... 87

19. ábra - E-learning tananyagfejlesztés eszközeinek kiválasztása (saját ábra 2019) .......................... 89

20. ábra - Értékelő kérdőív pontdiagram (saját ábra 2019) ………………………………............... 95

21. ábra - E-learning tananyagfejlesztés hatásai (saját ábra 2019) ……………………….............. 103

22. ábra - Kutatási eredmények értékelése (Vaishnavi és Kuechler, 2004) alapján (saját ábra 2019)111

23. ábra - Design Scienc kutatási ciklusok és kapcsolódó ellenőrzőlista elemek (1-8-ig számozással) (Hevner és Chatterjee, 2010) alapján (saját ábra 2018).................................................................. 141

24. ábra - Alkalmazott tananyagfejlesztési folyamat (saját ábra 2019) ........................................... 158 


\section{TÁBLÁZATJEGYZÉK}

1. táblázat - Kutatási kérdésekhez alkalmazott módszertanok és időrendje (saját táblázat 2019) ......... 9

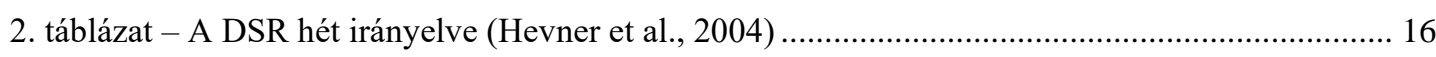

3. táblázat - A DSR hét irányelvének tervezett kapcsolódása (saját táblázat 2019) ………………..... 21

4. táblázat - Tananyagelemek (saját táblázat 2018) …………………………………………........ 38

5. táblázat - A tanulóközpontú e-learning tananyag jellemzői (saját táblázat 2019) ........................... 39

6. táblázat - A tartalomközpontú e-learning tananyag jellemzői (saját táblázat 2019) ......................... 40

7. táblázat - Publikációs kategóriák szókapcsolati elemzés alapján (saját kutatás 2018) ..................... 44

8. táblázat - Kapcsolódó fejlesztési modellek összefoglalása (Despa, 2014) alapján ........................... 49

9. táblázat - Szervezeti, innovációs és tanulási modellek Lam (2000) és Csizmadia (2015) alapján, e-

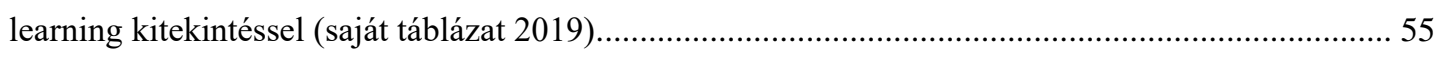

10. táblázat - Megfigyelt projektek és az új, $5 \mathrm{C}$ folyamattal kapcsolatos következtetések összefoglalása (saját táblázat 2019) 71

11. táblázat - Az e-learning tananyagfejlesztés folyamatának összefoglalása (saját táblázat 2019).... 72

12. táblázat - Az e-learning tananyagfejlesztés eredménytermékei (saját táblázat 2019) ..................... 77

13. táblázat - Eredménytermékek a tanulási célok nézőpontjából (saját táblázat 2019) ....................... 78

14. táblázat - Terméktípusok összefoglalása (saját táblázat 2019) ………………………………...... 80

15. táblázat - E-learning tananyagfejlesztés kulcsszerepeinek összefoglalása (saját táblázat 2019) ... 82

16. táblázat - Alkalmazott regressziós modellek és kapcsolódó (saját táblázat 2019)......................... 96

17. táblázat - Belső motiváció és a tanulási környezet (Aguilar et al., 2015; Niemiec és Ryan, 2009)

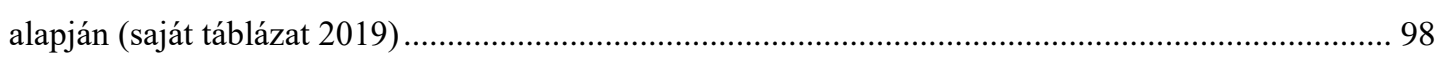

18. táblázat - A kutatásba bevont fejlesztések összefoglaló táblázata (saját táblázat 2019) ………... 100

19. táblázat - Projektek összefoglalása a megoldás konstruálása tükrében (saját táblázat 2019) ...... 101

20. táblázat - Projektek és társterületek kapcsolódása (saját táblázat 2019) ........................................ 103

21. táblázat - Projektek közvetlen és közvetett hatásainak összefoglalása (saját táblázat 2019) ....... 105

22. táblázat - A DSR hét irányelvének érvényesülése Hevner (2004) alapján (saját táblázat 2019) . 113

23. táblázat - Action Research és Case Study módszertanok összehasonlítása (Baskerville, 1997;

Blichfeldt és Andersen, 2006) alapján (saját táblázat 2019) ……………………………............. 143

24. táblázat - Alapképességvizsgálat tényezői és szempontjai (saját táblázat 2018) ………………. 169

25. táblázat - Fejlesztő eszközök jellemzői (saját táblázat 2018) ………………………………....... 170

26. táblázat - Pontozási szorzók szoftverek értékelése során (saját táblázat 2018) .......................... 171

27. táblázat - Értékelési segédlet (saját táblázat 2018) …………………………………............. 174 


\section{KÖSZÖNETNYILVÁNÍTÁS}

Szeretnék köszönetet mondani mindazoknak, akik idejükkel, gondolataikkal, kritikájukkal és tanácsaikkal támogattak és segítették e dolgozat elkészítését. Köszönettel tartozom feleségemnek és két gyermekemnek a türelmükért és szeretetükért. Köszönöm értékes tanácsait és folyamatos segítségét édesapámnak és a családom többi tagjának támogatását.

Külön köszönettel tartozom Nemeslaki András témavezetőmnek, mentoromnak, aki elindított és kísért ezen a hosszú úton. Folyamatosan támogatott egyfelől bölcs meglátásokkal, másfelől pedig lényegre törő ötletekkel.

Köszönöm Arany Zsuzsának, aki ugyanazzal a végtelen türelemmel válaszolt minden kérdésemre több tucat alkalommal, és köszönöm az Infokommunikációs Tanszéken és Informatikai Intézetben dolgozó munkatársaim folyamatos támogatását is.

Ezúton is köszönettel tartozom minden kollégámnak és megbízónak, akikkel együtt dolgoztam az elmúlt évek során, hiszen nélkülük nem valósultak volna meg azok a fejlesztések, amelyek a kutatáshoz nélkülözhetetlenek voltak. Külön köszönöm Csuvár Fruzsina és Mongyi Zsolt kollégáim sok-sok éves közös munkáját és aktív támogatásukat a dolgozat megírásával kapcsolatosan. Köszönöm interjúalanyaimnak, hogy időt szántak rám, és tapasztalataikkal, tanácsaikkal segítették munkámat.

Köszönöm a Magyar Nemzeti Bank Kutatási Kiválósági ösztöndíjának támogatását, és Schnellbach Máté munkáját a szövegelemzési vizsgálatokkal összefüggésben.

Végül, de nem utolsó sorban szeretnék köszönetet mondani Orbán Zsoltnak, aki kollégaként, szerzőtársként mellettem volt, támogatott a doktori képzésem és a közös munkák során. 


\section{BeVEzetéS - PROBlÉMÁK FELVETÉSE, KUTATÁSI CÉLOK ÉS A DOLGOZAT FELÉPÍTÉSE}

\subsection{Problémafelvetés - vezetőként helyt állni a gyorsan változó jogi, technikai, szervezeti erőforrás környezetben}

Szakmai életutam során számos esettel találkoztam, amikor egy (jellemzően nagy) szervezetben az emberi erőforrásokat és a szervezet általános folyamatait, működését érintő problémák megoldására, mint egyik lehetőséget, az e-learning rendszerek, eszközök, tananyagok bevezetését, fejlesztését választották. Az ilyen irányú fejlesztéseket helyes iránynak tekintem, hiszen az e-learning számos lehetőséget, eszközt és megoldást kínál egy szervezet számára a fenti problémák megoldására, de az e-learning sem csodafegyver önmagában. Vezetői támogatás, stratégiai elköteleződés, megfelelö erőforrások nélkül egy e-learninges megoldás kontraproduktívvá is válhat.

Egy mai vállalat-, emberi erőforrás-, IT-vezető munkája során folyamatosan változó piaci és szervezeti igényekkel szembesül: minden gyorsan változik (környezet, jogszabályok, ismeretek, termékek, eszközök, technológiák, emberek, belső és külső szervezetek stb.) - ugyanakkor a változások sebessége nincs összhangban (1.) sem egymással, sem korábbi folyamatokkal. A folyamatos változás egyre több meglévő tudást és egyre több új ismeret megszerzését igényli (2.). A folyamatos változás (is) komoly szervezeti fluktuációt eredményez (3.). Ezzel kapcsolatosan az Y-generáció megváltozott munkavállalási stratégiái (Gibson et al., 2009) és az Z-generáció munkaeröpiacra történő aktív belépése (GKI, 2016) további kérdéseket, nehézségeket vetnek fel. Mindezek miatt ismétlődő tudásfelhalmozási, tudásrendszerezési, tudásátadási igény (és kényszerhelyzet) keletkezik (4.), amely ismét újabb változásokat generál (1.). Pozitív visszacsatolással a jelenség tovább erősödik.

A fent vázolt problémakörre sok tudományterületről érkezhet válasz és megoldási alternatíva. Kutatások (Boroujerdi és Hasani, 2013; Akbari és Ghaffari, 2017) is igazolják a tudásmenedzsment és emberi eröforrás problémák kezelése közötti összefüggést. Igazolt a pozitív kapcsolat a tudásmenedzsment és az e-learning megoldások között is (Kö, 2011; Y1lmaz, 2012; Griggs et al., 2002; I-Chin Wu és Wen- 
Shan Chen, 2013). E megoldások támogathatják, hogy a tudás szervezeti szokássá váljon, és a rejtett tudás explicitté alakuljon (Kö, 2004).
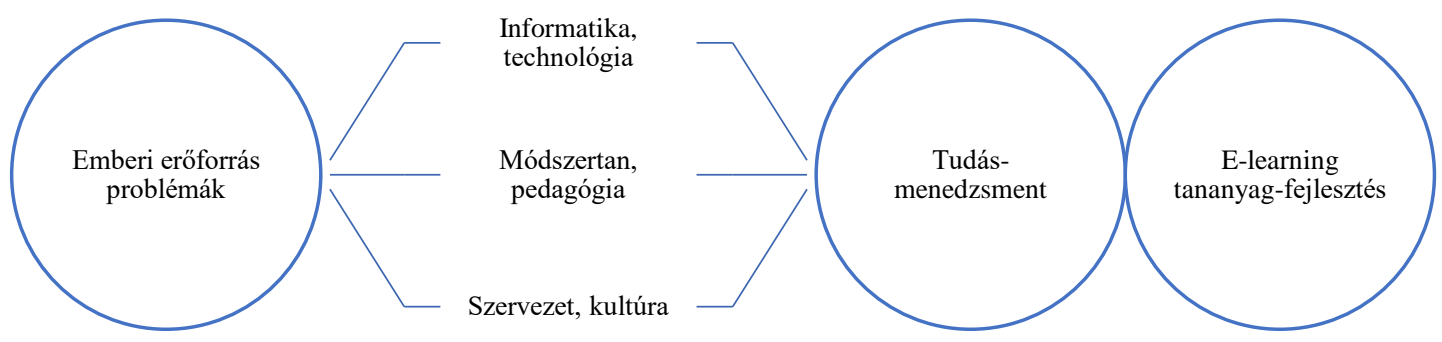

1. ábra-Problémamegoldási irányok (saját ábra 2019)

Célom, hogy összefoglaljam azokat a problémákat, amelyek az e-learning tananyagfejlesztés által kezelhetők. Azonosítani szeretnék egy új, tervezési és fejlesztési ciklusokra épülő folyamatot is, amely által az ,e-learning by design” szemléletben készülő tanuló- és tartalomközpontú tananyag jöhet létre.

A tudásmenedzsment körfolyamatként értelmezése (Probst et al., 2006) alapján nyolc elem azonosítóható: „a tudásprioritás meghatározása, a tudás azonosítása, a tudás megszerzése, a tudás fejlesztése, a tudás szétosztása, a tudás hasznosítása, a tudás rögzítése, és a tudás ellenőrzése" (Bencsik, 2014, p.30). Ezek tekintetében az elearning tananyagok a tudás megszerzésében, fejlesztésében, rögzitésében és ellenőrzésében játszhatnak döntő szerepet. A folytatásban (lásd 2.2 .2 fejezet) a tudásmenedzsment és az e-learning kapcsolódásának további értelmezését is kifejtem. A lehatárolás okán, jelen disszertáció fókuszában - részben terjedelmi korlátok kapcsán is - azért kerül fókuszba a tananyagok fejlesztése, mert e tananyagok azok, amelyekkel a tanulók (munkatársak) találkoznak, ezekkel kerülnek elsősorban kapcsolatba, ezek jellemezhetik a „megoldásokat”. E tananyagok jelentik sokszor a kapcsolódási pontot a problémák és a megoldások között. Továbbá e digitális termékek kialakítása során az 1. számú ábrán jelzett problémamegoldási irányok mindegyike kulcsszerepet kap, és a tananyag eredménytermékként, a teljes problémamegoldási út végpontjaként prezentálható. Úgy, hogy minden tudásrendezési és -tárolási vagy akár alkotási fázisok fontos szempontjait is figyelembe vette a szervezet.

A problémák megoldási lehetőségeit módszertani és technológiai oldalról is számos irányból érdemes kutatni és megvizsgálni. A vizsgálódás egyik fókuszát tehát azok a 
módszertani elemek adják, amely a technológiai kérdések mellett környezetet és keretet adnak a fejlesztéseknek. Ebbe beleérthetők az online felületekre támaszkodó újszerü tanulási, tudásátadási módszertanok (Bodnár és Sass, 2015; Bodnár et al., 2017). Továbbá betekintést, további fókuszt adnak a tanulást a szervezeti innováció részeként értelmező elméletek. Ezek egy része ellentétes fogalomként tekint a tanulásra és az innovációra. Más elméletek összemossák a kettőt, de akad olyan is, mely egyértelmü összefüggést mutat ki. Eszerint a tanulás feltétele az innovációnak (Hámori, 2012).

A fentiek komplex keretrendszereket és kapcsolódó informatikai megoldásokat vetítenek előre. Az is látható, hogy ezek a keretrendszerek nem kizárólag technológiai eszközök, hanem szorosan kapcsolódnak a vállalati kultúra és a szervezet alakításához is (Kő és Klimkó, 2009). A komplex rendszerek kialakítása során számos szempontot szükséges érvényesíteni a környezeti tényezőktől kezdve a vállalati folyamatok ismeretén, a technológiai szempontok figyelembevételén át, a célok azonosításáig (Klimkó, 2001). E megközelítések együttes szem előtt tartása pedig nem csak a teljes szisztémára érvényes, de annak minden egyes eleme kialakítására és fejlesztésére külön-külön is igaz lehet. Ez függetlenül attól, hogy megoldásunkat csak egy digitális tananyag-tartalom fejlesztésével vagy akár egy összetett, ontológia alapú, e-learning rendszerhez (Learning Management System: LMS) kapcsolt tudásmenedzsment környezetben hozzuk létre, amely támogatja a vállalatok kodifikációs törekvéseit (Kö, 2011).

A gyakorlati tapasztalat azt mutatja, hogy miközben a fent, az 1. ábrán szemléltetett, területek sok esetben és sok módon és sok szálon kapcsolódik egymáshoz, ugyanakkor egyik sem élvez elsőbbség a többivel szemben. Mindegyik terület kereteket és alapokat helyez el a fejlesztési projekt „alatt” és „körül”. Jó esetben ezek összeegyeztethető, szabványos építőelemek (pl. videós tartalmak esetén rendelkezésre áll vagy bővíthető a tárhely, és a tartalmak kiszolgálják a téma pedagógiai igényeit is, és a szervezett is nyitott az ilyen tartalmak fogyasztása irányába), rossz esetben komoly akadályozó tényezők (pl. nincs hangszóró a végfelhasználói gépeken, miközben a módszertani igény hanganyag alkalmazása, és a kulcsszereplők nem döntenek).

Az informatikai oldal, amely a technológiai alapokat (pl. szerver, tárhely stb.) és a lehetőségek tárházát nyújtja: virtuális valóság (Tretsiakova-McNally et al., 2017), 
kiterjesztett valóság megoldások (Balkányi és Orbán, 2011), fejlett animációk stb. Továbbá számos, a felhasználói élményt csorbító korlátot is jelent (pl. IT biztonsági elvárások, tárhely korlátok stb.), másfelől pedig komoly anyagi kereteket (pl. adott technológia fejlesztési költségei) határozhat meg. Jó példa erre a Cranfield Egyetem két szerzőjének meglátásai, akik rámutatnak, hogy az e-learning keretrendszerekre éppen úgy szükséges tekinteni, mint bármilyen más informatikai rendszerre, és éppen ezért ugyanúgy szükséges a megfelelő biztonsági kereteket kialakítani (Mohd Alwi és Fan, 2010).

A szervezet és a kultúra alapvető hozzáállást határoz meg mind a technológia, mind a módszertan irányába (pl. mennyire nyitott vagy elzárkózó egy szervezet egy-egy új technológiai vagy módszertani megoldásokra). A támogató környezet megteremtésének fontosságát empirikus kutatások is igazolják. (Yoo et al., 2012) De ugyanitt gondolhatunk a szervezet felépítésére is, amely kereteket határoz meg a fejlesztési projektek lefutásával kapcsolatosan (pl. erőforrások hatékony biztosítása, döntéshozatal struktúrája stb.). Szervezeti oldalról a legjelentősebb nehézséget a képzési terület „mostoha” szerepe jelenti leginkább. Jellemző, hogy míg a (magyar) vállalatok életében a pénzügyekkel és a dokumentumok kezelésével kapcsolatos rendszerek szinte mindenhol megtalálhatók, addig az e-learning tananyagok befogadását támogató keretek (pl. LMS) vagy a tudásmenedzsmentet támogató megoldások kevéssé érhetők el (Szabó és Fehér, 2010).

A módszertani és pedagógia oldal pedig - mivel az egész folyamat ennek a területnek az eredményeit alapoz - minden fejlesztésre vagy proaktív megoldásokat nyújt (pl. ha nem lehet videókat lejátszani, akkor olyan módszertani megoldást alkalmaz, amely animált képekkel dolgozik) vagy gáncsolja az elörehaladást, olyan elvárásokkal, amelyeket a másik két „oldal” nem tud kiszolgálni. Erre példa egy olyan hosszú fejlesztési folyamat, amelyre nincs anyagi keret. Vélhetően e kérdéskörre nem találhatunk fekete és fehér megoldásokat (Burbules és Callister, 1999), de a pedagógia és annak módszertana fontos tényező, amely alapjaiban határozhatja meg egy fejlesztés, projekt sikerességét.

Egy e-learninggel támogatott képzési keretrendszer, jelentős integráló erőként tud müködni vállalati vagy intézményi térben. A képzések teljes rendszerének tudatos, több szempontú megtervezése, kialakítása, majd alkalmazása sikeres válaszokat adhat 
a fent vázolt problémákra (Griggs et al., 2002; Chang, 2016). A teljes keretrendszerben pedig szerepe kell, hogy legyen az e-learning rendszereknek, tananyagoknak, egy olyan digitális eszköztárnak, amely hatékonyabbá, gyorsabbá, elérhetőbbé, (közép vagy hosszú távon) olcsóbbá teheti a meglévő vállalati és lehívható külső tudás használatát. Előbbiek összessége pedig segíthet a folyamatosan és gyorsan változó környezet és struktúrák adta problémák leküzdésében, a visszacsatolási „örvény” csillapításában.

\subsection{Kutatási célok azonosítása - szisztematikus válasz a megoldandó problémákra a digitális tananyagok fejlesztésén keresztül, az üzleti ökoszisztéma keretrendszerében}

A kutatás rendező elve az, hogy a Design Science módszertani iránymutatása alapján, a tézis felépítési keretei mentén gyüjtsem össze azokat a problémákat, amelyekre a digitális tananyagok fejlesztése nyújthat megoldást. A disszertációban az igen széles eszközzárral dolgozó teljes e-learning területén belül a tananyagfejlesztésre kívánok fókuszálni.

A kutatás során szisztematikusan dolgozom fel azokat a számomra mérföldkőnek tekinthető projekteket, amelyekben részt vettem, amelyeket dokumentáltam és megfigyeltem. A kutatás módszertani kereteket és az alkalmazott technikákat a 1.4.2 fejezetben foglalom össze.

A kutatás során megvizsgálom és feltárom az e-learning tananyagfejlesztés ökoszisztémáját, amelynek fontos része a társterületek feltárása is. A kutatásokat nagy szervezetekre vonatkozóan végzem el, amelyek jellemzője (saját meghatározás szerint), hogy legalább 100 munkatárssal, önállóan működő emberierőforrás irodával és jellemzően 1 milliárd forint feletti árbevétellel vagy működési költséggel rendelkezik. E keretek szükségesek ahhoz, hogy egy szervezet számára szükséges legyen megfelelő minőségű és mennyiségű e-learning alapú képzéssel számolni. Továbbá az ekkora szervezetek rendelkeznek akkora személyi és anyagi erőforrás kerettel, amely elégséges egy-egy ilyen típusú fejlesztés elvégzéséhez.

Az üzleti ökoszisztéma fogalmi kerete James F. Moore (1996) munkáiban megjelenő gazdasági rendszerszemléletére tekintek. Az üzleti ökoszisztéma szervezetek és az egyének interakciója müködteti, miközben árukat és szolgáltatásokat hoznak létre 
egymásnak. A közös rendszer pedig együttes fejlödést, közös evolúciót jelent a résztvevőknek. Ezen ökoszisztéma fogalmi keret jelenti kutatásom során az e-learning tananyagfejlesztés tágabb értelmezését.

Javaslatot teszek egy olyan e-learning tananyagfejlesztési folyamat modelljére, amely magánban foglalja a legfontosabb kapcsolódó területek elemeit is. Elsődleges célom a kutatás eredményeként azonosítani és részletesen leírni egy ciklusokból felépülö tananyagfejlesztési folyamatot és annak eredményeit, másodlagosan a lehetséges fejlesztési eszközöket és a fejlesztés résztvevöit is. Harmadsorban célom az is, hogy megismerjem a fejlesztések eredményét, a részevők szöveges visszajelzéseinek elemzése és további mélyinterjúk alapján. Így választ kapok arra, hogy az összegyüjtött problémák közül, a leírt e-learning tananyagfejlesztés melyekre nyújt(hat) megoldást. Zárásként pedig összegyüjtöm, a Design Science nézőpontból is fontos, gyakorlati meglátásokat, amelyek segíthetik az e-learning tananyagfejlesztés folyamatát.

A képzések szisztematikus fejlesztése, kialakítása számos témát és megoldandó szervezeti kérdést vet fel. Sokszor az e-learning rendszer világít rá egy szervezet addig lappangó információtechnológiai problémáira, pl. amikor a felhasználói adatokat tartalmazó háttéralkalmazásban uralkodó „káosz” kerül napvilágra a minden munkavállalót érintő e-learning alkalmazás bevezetése előtt. A háttéralkalmazás(ok) kényszerü tisztítása ilyenkor más területeken is megoldást nyújt. Maga az e-learning rendszer is egy információ- és kommunikációstechnológia (ICT) alkalmazás, amely újra-értelmezheti az üzleti folyamatokat is (Davenport és Short, 1990). Találkoztam olyan szervezettel is, ahol egy szakterületi téma digitális tananyaggá történő feldolgozása során átalakult a teljes szervezet hozzáállása és szemléletmódja az addigi képzési modelljükkel szemben. Az anyagok építőelemeire szétszedését követően vált világossá, hogy számos értelmetlen, elavult vagy a tanulók által haszontalannak tartott tartalmat oktatnak. Ez a jelenség nem ismeretlen a nemzetközi szakirodalom számára sem (Moisio és Smeds, 2004). Hasonló problémák ismertek más informatikai eszközök implementálása kapcsán: „,... hogy alakítsunk ki taktikát egy olyan játékhoz, amit még nem is játszottunk?” (Orlikowski, 1993, p.243). Ezt a kérdést tette fel a szerző egy csoportmunka alkalmazás bevezetése kapcsán, miközben rámutatott, hogy 
a sikeres ICT bevezetések során a szervezet technológiai keretei és munkamódszerei is változtatást kívánnak (Orlikowski, 1993).

Minden esetben alapvető nehézség az informatikai és módszertani ismeretek, területek összehangolatlansága. Ez sokszor ered a magas szintü tudásmenedzsment rendszerek kiépítését korlátozó adott technológia határaiból, illetve az alkalmazni kívánt módszertani ismeretek és a jelenléti tréning megoldások hiányosságaiból. A kutatott e-learninges képzésnek és annak elemeinek kialakítása során fontos megérteni, hogy ez a folyamat nem egy tipikus ICT fejlesztés, továbbá nem is a meglévő ismeretek egyszerü digitális lefordítása, lenyomata, hanem új minőség: a „tudásfogyasztás”, az ismeretek átadásának és megszerzésének egy új megközelítése. Az „e-”, mint ahogy sok más iparágnál láthattuk (Cassidy, 2002; Nemeslaki, 2012; Hanelt et al., 2015; Degryse, 2016), teljesen új folyamatokat és teljesen új megoldásokat vár el, és kínál is egyben.

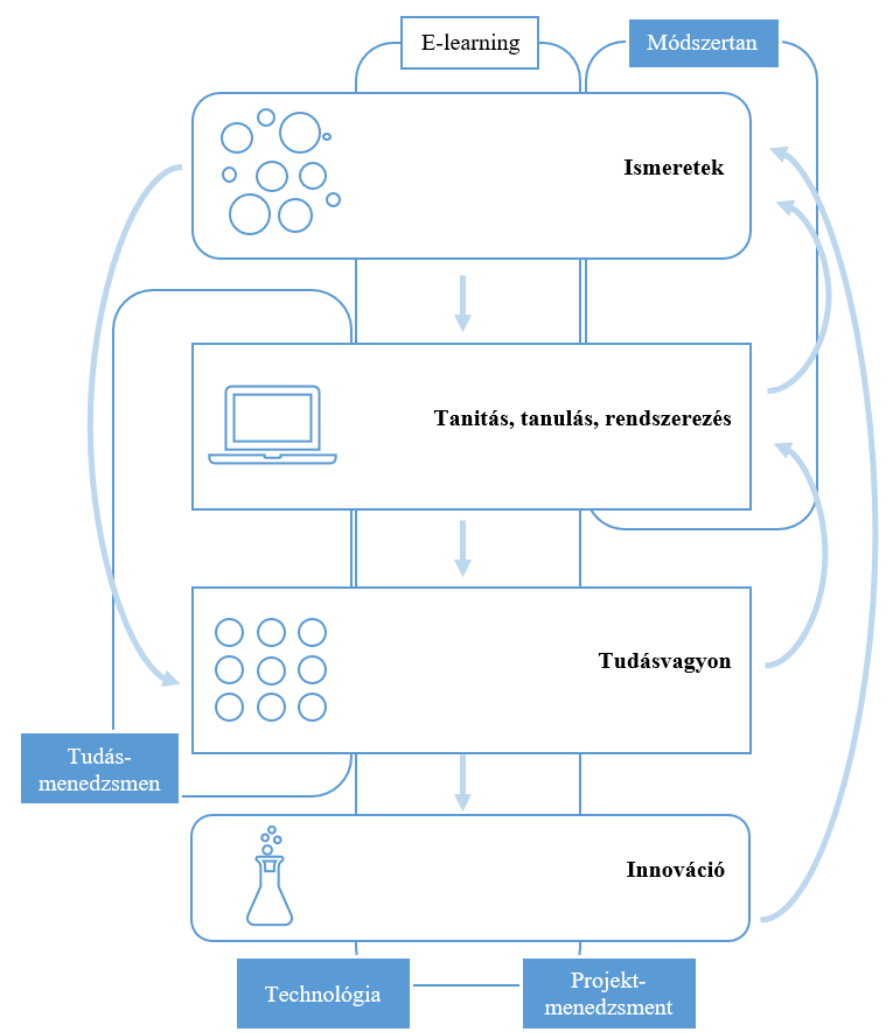

2. ábra-Kutatási területek és témák azonositása (saját ábra 2018)

A termékek (e-learning tananyagok) ugyan végül csak adott ICT környezetben értelmezhetők (hiszen digitális tartalmak), de a lényeg mégis a tartalom és annak reprezentációja. 
Ezért is állítom dolgozatom fókuszába az e-learning tananyagfejlesztési folyamatot, amelyben sok, szerteágazó tudású szakértő dolgozik együtt.

Ahogy a 2. ábrán is látható, kiemelten fontos, hogy egy érvényes, jól strukturált, projektmenedzsment módszertannal megtámogatott fejlesztés során már a legelső pillanatban tudjuk, hogy olyan képzést, olyan tananyagokat hozzunk majd létre, amely vagy teljes egészében vagy részben, de képernyő(k) előtt zajlik majd. Ez pedig számos esetben új tudás feltárását, új ismeretek beemelését, régiek elvetését jelenti: az ismeretek tanítása, tanulása és rendszerezés által. Ez igaz nem csak szakterületi, szakértői szempontból, hanem ICT és módszertani oldalról is. Az eredmény pedig a tudásvagyon összefogásával, rendszerben történő kezelésével olyan innovatív folyamatok alapja lehet, amely végső soron a vállalat versenyképességének egyik elemévé vállhat (Bencsik, 2014). Az új ismeretek beemelésével új tanulási ciklus is indulhat.

\subsection{Kutatási kérdések - a problémakörök áttekintése}

A fentiek alapján a kutatás során az alábbi fő kérdésekre keresem a válaszokat:

1. Hogyan rendszerezhetők az e-learning ökoszisztéma elemzéséhez szükséges társterületek?

2. Milyen jellegzetes - nagy szervezetekre jellemző - problémák, illetve problémacsoportok megoldásában alkalmazható az e-learning tananyagfejlesztés?

3. Hogyan jellemezhető és írható le az e-learning fejlesztés során kialakuló fejlesztési ökoszisztéma?

4. Milyen közvetlen és közvezetett eredményei, hatásai lehetnek egy kifejezetten a képernyő előtti tanulásra fejlesztett, e-learning tananyag alapú vagy azokkal támogatott képzésnek?

\subsection{A kutatás és a dolgozat felépítése - röviden a kutatás kereteiről és szerkezetéről}

E fejezetben ismertetem a dolgozat felépítését, tagolását, és röviden bemutatom a kutatás módszertani elemeit és kerettervét. 


\subsubsection{Dolgozat szerkezete, felépítése, tagolása - röviden az útról}

A kutatás kerethez alapként Hevner és társai (2010; 2004) „alapműveit” és annak módszertani kereteit tovább részletező feldolgozását, továbbá Offermann és társai (2009) rendszerét használom fel. A folytatásban részletes taglalásra kerülö design science, és annak kutatás módszertani kibontása az elmúlt közel 15 évben számos irányból vizsgálat tárgyát képezte. Jelen dolgozatomban ezeket a kutatási eredményeket és a kapcsolódó, iskolateremtő gondolatokat is fel kívánom használni (Peffers et al., 2007; Nemeslaki, 2011c, 2011b).

\begin{tabular}{|c|c|c|}
\hline $\begin{array}{l}\text { Kutatási } \\
\text { kérdés }\end{array}$ & Kutatási módszertan, technika & Fejezet, időrend \\
\hline KK1 & $\begin{array}{l}\text { irodalomfeldolgozás, szövegelemzés, } \\
\text { akciókutatás }\end{array}$ & $\begin{array}{l}2.2 \text { Az e-learning társterületek azonosítása és } \\
\text { elemzése - az érintett területek felkutatása és } \\
\text { áttekintése }\end{array}$ \\
\hline KK2 & $\begin{array}{l}\text { mélyinterjú, beágyazott probléma } \\
\text { megoldás, esettanulmány feldolgozás } \\
\text { (gondolattérkép) }\end{array}$ & $\begin{array}{l}\text { 3.2 Problémák azonosítása - a kutatás által } \\
\text { megvizsgálni kívánt terület } \\
\text { problématérképének felrajzolása }\end{array}$ \\
\hline KK3 & $\begin{array}{l}\text { mélyinterjú, akciókutatás } \\
\text { (dokumentáció feldolgozása, } \\
\text { empirikus tapasztalatok), } \\
\text { irodalomfeldolgozás }\end{array}$ & $\begin{array}{l}\text { 3.3 Megoldás konstruálása - (1.) a } \\
\text { tananyagfejlesztési folyamat felépítése, (2.) a } \\
\text { termék, (3.) kapcsolódó szerepek és (4.) } \\
\text { eszközök bemutatása }\end{array}$ \\
\hline KK4 & $\begin{array}{l}\text { akciókutatás, szövegbányászat, } \\
\text { mélyinterjú }\end{array}$ & $\begin{array}{l}\text { 3.4 Projektek összefoglalása és értékelése - } \\
\text { az e-learning ökoszisztéma tükrében }\end{array}$ \\
\hline
\end{tabular}

A disszertációban felvetett kérdéseket elsősorban azokon a projekteken keresztül kívánom kutatni, amelyekben személyesen is részt vettem az elmúlt évek során. Az általam vizsgált e-learning tananyagfejlesztés területe gyakorlatorientált, hiszen valamilyen konkrét vállalati problémára keres megoldást. A fejlesztések során tapasztalható kísérletezés, problémakeresés alapvető lehetőséget nyújt akciókutatási (action research - AR) szemléletü, aktív részvételen és változtatási igényre alapuló kutatások folytatására (Adelman, 1993). Az AR mellett az esettanulmány (case study - CS) alapú kutatási stratégiát alkalmazom az egyes a vizsgálatokba beválogatott projektek esetében az elemzések elmélyítése érdekében. (A kutatásmódszertani szakszavak esetében a folytatásban az angol kifejezéseket és rövidítéseket alkalmazom, elsősorban a könnyebb követhetőség, és a magyar fordítások 
esetlegessége okán.) Míg az AR és az CS módszertan is kutatási stratégiaként és szemléletmódként jelennek meg a disszertáció elkészítése során, addig a konkrét kutatási technikák tekintetében irodalomfeldolgozásra, mélyinterjúkra, megfigyelésekre, szövegelemzési és szövegbányászati módszerekre kívánok támaszkodni az adott kutatott kérdéshez illeszkedően az 1. táblázatban leírtak alapján. A kutatások elvégzését követően összefoglalom a tudományos eredményeket és következtetéseket. Rendszerbe foglalok egy fajta tananyagfejlesztési folyamatot, amely iránymutató modellje kíván lenni az olyan típusú fejlesztéseknek, amelyek a „privacy by design” (Cavoukian, 2011) elvéhez hasonlóan az e-learning by design elvét valósítják meg, és céljuk, hogy a feltárt, valós problémákra keressenek valós, a gyakorlatba ültethető megoldásokat.

\subsubsection{Az alkalmazott módszertani elemekről - kutatási keret és kutatási stratégiák választásának okai és háttere}

Az előzőekben összefoglalt kutatási célok eléréséhez - ahogy fent jeleztem - Hevner és kollégái (2004) által bemutatott „,design science” (DS - konstruálás tudománya) modelljét kívánom alkalmazni, amely az ICT kutatások között igen jelentős irányzat. Erre erősen reflektál a Nemeslaki (2011c) által a gazdaságinformatikai képzésekhez kapcsolódóan a komplex rendszerfejlesztések esetében hangsúlyozott kettősség, amely szerint az egyik oldalon kifejezetten pragmatikus kérdések, és az azokra adható innovatív, gyakorlati ICT megoldásokat állnak, míg a másik oldalon ennek tudományos igényü reprezentációja, amely illeszkedik a szakma nemzetközi fejlődési vonalához is (Sein et al., 2011). A szakirodalomban is találhatunk DS megközelítésü kutatásokat (design science research - DSR) kifejezetten a tanítás és tanulás perspektívájából is (Laurillard, 2013). Számosan alkalmazták a módszert oktatási rendszerek, eszközök fejlesztésével összefüggésben is (Oyelere et al., 2018; NorthSamardzic, 2015). A design (a tervezési) szemlélet és a gyakorlatban alkalmazott kutatás az oktatás világához is igen közel áll. Schoenfeld (2006) 10 évig folytatott „design kísérletei” (design experiments) során egyértelmű eredményre jutott azzal kapcsolatosan, hogy a laboratóriumi oktatás módszertani kísérletek lefolytatása teljesen más eredménnyel zárulnak a gyakorlati, oktatótermi vizsgálódással szemben. Meglátása szerint ezeket a típusú vizsgálódásokat nem is szükséges laboratóriumi körülmények között végezni, hanem kifejezetten gyakorlati helyzetek alapján lehet 
megfelelö kutatási eredményhez jutni. A DSR megközelítés jól illeszkedik a kutatás egyik céljaként meghatározott, olyan újszerü megoldás felkutatásához is, amely elsősorban müködőképes, a piacképes, kielégítő megoldást keres. A DSR megoldás nem minden dimenziójában mérhető, több tudományterület határán mozgó kérdéseket vet fel, viszont szigorú és objektív módszerekkel kutatható (Sargent, 1991).

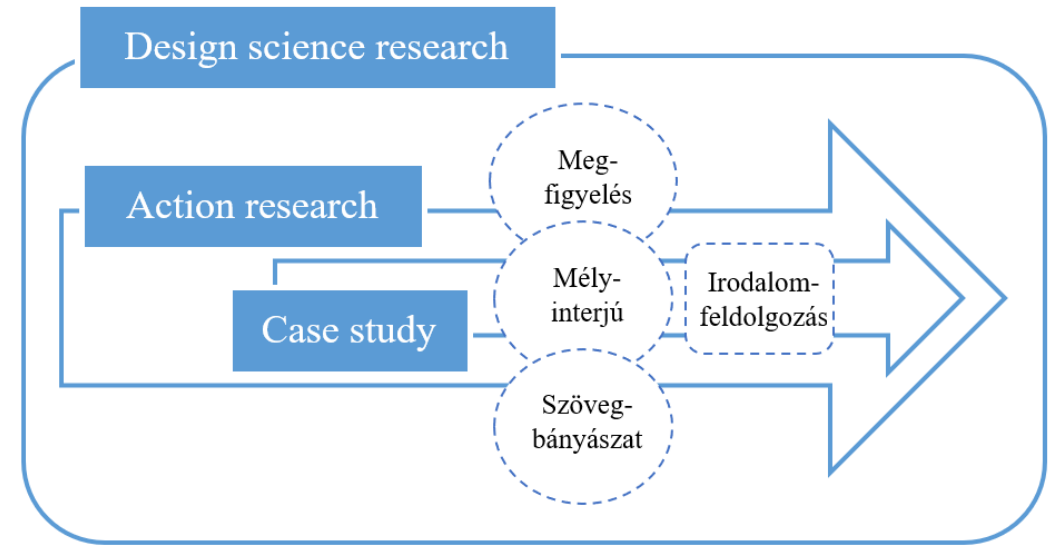

3. ábra - Kutatásmódszertani összefoglalás (saját ábra 2019)

A kutatási keretet összefoglaló 3. ábrán látható, hogy a dolgozat személyes és gyakorlati aspektusa hogyan jelenik meg az (elsősorban participatív) „action research" (AR - akciókutatás) nézőpont alkalmazása során. Ilyen nézőpont pl. a kooperatív szemlélet, mely alapja a kutatási és fejlesztési folyamatban való aktív részvétel, de ilyen az elméleti szempontok mellett hangsúlyos tényező a gyakorlati eredmények kutatása, elemzése is (Csillag, 2016). A szakirodalom szerint igen erőteljes kapcsolat és támogató aspektusok mutathatók ki az AR és a DS között (Järvinen, 2007; Cole et al., 2005). Mindkét megközelítés proaktív és a kutatás aktív, beavatkozó tagjaként tekint a kutatóra. A szerzők ugyan azonosítanak ismeretelméleti különbségeket, de mindkét alkalmazott módszertan esetében a kutatás és a problémák megközelítés igen pragmatikus alapokon nyugszik. Ezt a gyakorlatorientált szemléletet kívánom én is alkalmazni, és beépíteni jelen dolgozatom kutatás módszertani megközelítésébe, alapvetően a DS által meghatározott szigorú kutatási keretek és feltételek között.

E kutatásmódszertani megközelítésekhez közel áll - bizonyos kutatási szempontok szerint más-más fókusszal alkalmazható - a „case study” (CS - esettanulmány) módszer. E módszer egyik oldalról ismert megközelítés a Gazdaságinformatika és Gazdálkodástudományi Doktori Iskolák müködésén belül is (Szabó, 2000; Klimkó, 
2001; Fehér, 2004; Varga, 2014; Török, 2014; Bartis, 2014; Monda, 2018), másik oldalról pedig jól kiegészíti jelen disszertáció holisztikus AR nézőpontját. (A két kutatási stratégia összehasonlítása a 6.4 fejezetben található.) A CS szemléletü vizsgálódás esetében a kutatás elemi része, hogy megfigyeljük és elemezzük a helyzeteket, keressük a válaszokat a „hogyan” és „miért” kérdésekre, de önmagában (és környezet ismerete nélkül) a kutatás nem nyújt, és nem is megoldást keres, hanem szisztematikus vizsgálatot jelent egy kifejezetten gyakorlatorientált kérdéskörben (Yin, 1984; Benbasat et al., 1987; Zolnai, 2016). Az esettanulmány alapú kutatás „szükséges és elégséges módszer” (Flyvbjerg, 2006, p.241), és megállja a helyét a jellemző kritikákkal szemben, amelyeket Bent Flyvbjerg (2006) foglalt össze.

\subsubsection{A dolgozat konkrét kutatás módszertani kereteinek meghatározása - a kutatás felépítése}

A fenti tagolás alapján a dolgozat következő fejezeteiben a DSR kutatáshoz kapcsolódó alapvető háttérismerteteket és kutatásmódszertani elméleteket ismertetem. A disszertáció gerincét adó kutatást, egyfelöl design science research ciklusokra (DSRC) (Hevner, 2007), valamint DSR ellenőrző listájára (Hevner és Chatterjee, 2010) másfelől Offermann és társai (2009) által leírt DSR kereteire támaszkodva viszem végig. A Hevner és Offerman által felvázolt kutatási folyamatot követve vizsgálom és mutatom be a válaszokat a felvetett kérdésekre, és folytatom le a DS alapelveinek megfelelő kutatást, amelyet összefoglalva az alábbi, 4. ábra szemléltet. 


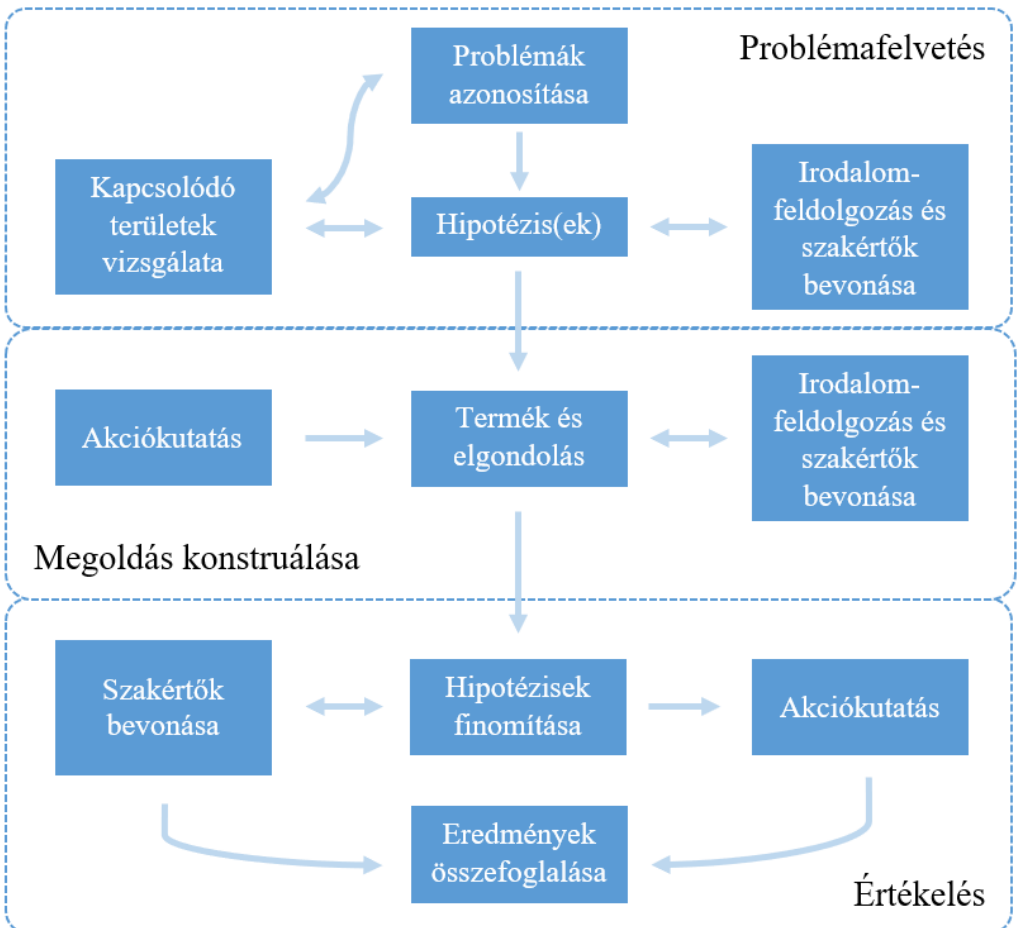

4. ábra-DSR kutatás felépitése (Offermann és mtsai. 2009) alapján (saját ábra 2018)

Offermann (2009) munkája alapján a kutatási kérdéseket, és az azokra adott válaszokat, továbbá a kapcsolódó elemzéseket a kutatási kérdések hármas tagolása mentén valósítom meg.

I. A problémafelvetés során a kapcsolódó területek vizsgálata mellett szükséges megismerni a problémák konkrét és szisztematikus azonosításával azokat kérdéseket, az e-learning tananyagfejlesztés által kezelt fájdalmas pontokat, amelyek léte alapozzák meg a kutatást. Ehhez a szakaszhoz már konkrét kutatási kérdések is kapcsolódhatnak. A problémák azonosítása az a kiinduló pont, amelyhez hozzá füzhető a társterületek tanulmányoza, valamint a szakirodalom áttekintése.

II. A megoldás konstruálása során megvizsgálom a felvetett problémákra tervezett válaszok alapján azokat a gyakorlatban alkalmazott megoldásokat, amelyek az e-learning tananyagfejlesztés folyamatát, termékeit, résztvevőit és eszközeit jelentik, szigorú kutatásmódszertan alkalmazása mellett. 
III. A kutatás záró szakaszában, az értékelés során szükséges finomhangolni a téziseket, akár a problémafelvetések újragondolásával, majd összefoglalni a különböző kutatás-módszertani keretek között az eredményeket, a gyakorlatban is alkalmazott megoldások bemutatásával.

A hármas tagolása részletesebben a melléklet 6.2 fejezetében olvasható, amely tükörképként és vonalvezetőként támogatja a fő kutatási kérdések által felírt ívet is (lásd 1.2 pont). Ez nyújt lehetőséget a szisztematikus és szigorú, tudományos vizsgálatok, elemzések elvégzésére egy gyakorlatorientált, termék és eredmény központú multidiszciplináris terület vizsgálata kapcsán (Holmström et al., 2009).

A disszertáció írása során a tagolást a tananyagfejlesztés nézőpontja alapján vezetem végig. A problémafelvetés kapcsán az emberi erőforrás és a bevezető fejezetben felvetett egyéb kérdéseket kibontva és szisztematikusan vizsgálva haladok. Minden esetben célom a tananyagfejlesztéshez jól kapcsolható elemeket azonosítani. A disszertációban a problémafelvetések között példaként mélyebben az új belépők képzésének lehetőségeit mutatom be (ehhez kapcsolódó tananyagok okán), szemben pl. az adminisztrációs feladatokkal kapcsolatos nehézségekkel, mert azok sokkal inkább az e-learning rendszerek oldaláról megfoghatók. A megoldás konstruálása során már kifejezetten az e-learning tananyagok fejlesztése áll a vizsgálódás fókuszában, hiszen a problémafelvetés által kijelölt irányokat ilyen megoldások konstruálása felé kívánom terelni - megvizsgálva a szervezeti innovációhoz és a problémák megoldásához való hozzájárulást. Az értékelési fázisban pedig a tananyagfejlesztések eredményeit kívánom megvizsgálni, amelyek az előző két fázisban felmerül hipotézisek újra gondolását, és átformálását is eredményezhetik. Egy tananyagfejlesztés, annak tudásreprezentációs funkcióján túl, egy egész szervezet számára minőségi változást jelent és választ adhat a felmerül problémákra vagy legalábbis egy részükre.

A folytatásban az e-learning tananyagfejlesztési folyamathoz kapcsolódó kutatásmódszertani kereteket és a mögötte álló tudományos eredményeket és meghatározásokat kívánom részletesen bemutatni. Minden későbbi kutatási elem, vizsgálat és eredmény, amely jelen disszertáció része, az elmúlt évek gyakorlati 
szakmai tapasztalatainak szigorú, a DSR személetmódjához illeszthető elemeinek összefoglalása, szintézise és (remélhetőleg) eredménye, terméke. Kiemelten fontosnak tartom a háttér relevanciájának részletes bemutatását.

\subsection{Design Science - az alapok ismertetés és a disszertációban alkalmazott szempontok kifejtése}

A DSR két fontos szempontját tartom szem előtt: a tudományos szigor a megfelelő módszertanok kiválasztásával érhető el, a kutatás relevanciáját pedig a megfelelő környezetbe illesztett termékkel összefüggésben érkező visszajelzések adják (Hevner et al., 2004). A tudományos szigorúság az eredmények hatékonyságával, használhatóságával és megbízhatóságával értékelhető, amelyhez megfelelő értékelési metódus kiválasztása kulcsfontosságú. Ilyen pl. a Design Science Értékelési Keretrendszere (FEDS) (Venable et al., 2016). A tudományos művek relevanciája elérhető cél. Egy kutatás releváns, ha (1.) fontos gyakorlati kérdésekre keresi a választ, (2.) maga a kutatás elérhető a gyakorlatban alkalmazó szakértők által is (nem csak a tudományos folyóiratokban), és ha (3.) elöre definiált és megtervezett alkalmazhatósági ellenőrzésen esik át, amely egyébként ciklikusan ismétlődik is (Rosemann és Vessey, 2008).

A disszertáció kutatási keretként alkalmazott rendszer (Offermann et al., 2009) alapjait tekintve a Hevner (2004) által lefektetett hét irányelvből fakad, amelyek az alábbiak.

Irányelv

1. Tervezés, mint termék

2. Releváns probléma

3. Értékelés

4. Kutatási érték

5. Kutatási szigor

6. Tervezés, mint keresési folyamat
Leírás

A DSR-nek eredményeznie kell egy müködő terméket a tervezés, modellezés, eljárás formájában.

A DSR célja, hogy egy technológia alapú megoldást fejlesszünk fontos és releváns üzleti problémák megoldására.

A tervezett termék hasznosságát, minőségét és hatásosságát szigorúan kell értékelni egy jól végrehajtott értékelési eljárás alapján.

A hatásos DSR-nek világos és igazolható eredményeket kell felmutatnia a tervezett termék, a tervezés alapjai és módszerei esetében.

A termék kialakításában és értékelésében egyaránt szigorú módszereket kell alkalmazni.

A hatásos eredmény megtalálása érdekében a keresés során szükséges a rendelkezésre álló eszközök olyan 
A következő fejezetekben részletesen ismertetem a design science (DS), az action resarch $(A R)$ és a case study $(C S)$ elméleti alapjait, jellemzőit és részleteit alkalmazhatóságát keresve és megtalálva az e-learning tananyagfejlesztés terültén.

\subsection{1 Általánosan a Design elméletekről - történeti háttér és a megoldhatatlan problémák}

Az 1990-es évek elején az információrendszerek és az informatika tudományterületét komolyan foglalkoztatta annak megértése, hogy hogyan tud egy adott információtechnológiai termék (IT artefact) megoldást adni egy valós üzleti problémára. Ebbe a diskurzusba hoztak, nem kizárólag, de elsősorban Nunamaker (1990) valamint March és Smith (1995) áttörést a DS bevonásával. Hevner és munkatársai (2004) pedig a Management Information Systems Quarterly hasábjain megjelent publikációjában már konkrét iránymutatást adtak az olyan kutatások terén, amelyek esetében nagyon is „kézzel fogható” és gyakorlati problémákra, „kézzel fogható" és gyakorlati, (itt már) infokommunikációs technológiákat kiaknázó megoldásokat kívántak alkalmazni a kutatók. A korábbi, az üzleti folyamatok elemzésével dolgozó szemlélettel szemben, a DS alapvetése szerint egy termék (artefact) készitése során ismerhetjük meg pontosan a problémákat és az azokra adott válaszokat (Hevner et al., 2004; Genemo et al., 2016). E problémák többségében komplexek, végesek és normatívak (Farrell és Hooker, 2013). Sokszor lehetetlen szétválasztani az egyéni elemek következményeit az összetett, egymással összefüggő hatásoktól. Ez a probléma megértés megfelelő terepet jelenthet a DS szempontú kutatáshoz (Hellmuth és Stewart, 2014). Ezeket nevezzük „,wicked problems”-nek, (March és Smith, 1995), amelyeket a magyar szakirodalom „ördögi”, „komisz”, „kacifántos”, „elvetemült” vagy „megoldhatatlan” problémaként ír le (Devins és Jones, 2016; Slézia, 2012; Herendi, 2017). A „wicked problems”-nek tekinthetö kérdéskörök Hevner és munkatársai által az alábbi öt jellegzetességgel rendelkeznek: „(1.) rosszul meghatározott és instabil környezetben meghatározott követelmények és korlátok. (2.) komplex kölcsönhatások találhatók a probléma és a megoldás részei 
között, (3.) a tervezési folyamatok és termék alapvető rugalmassága (pl. képlékeny folyamatok és termékek), (4.) a hatékony megoldás esetében kritikus függés a részvevők kognitív képességeivel (pl. kreativitás) kapcsolatosan, (5.) kritikus függőség az emberek szociális képességivel kapcsolatosan.” (Gleasure, 2013,p.1) Más szerzők további tíz szempontot azonosítottak, amelyek közül kiemelendő, hogy a megoldhatatlan problémák: nincs egyértelmű megoldás és egyediek, „nem igazak vagy hamisak vagy jók és rosszak”, az esetükben „nincs azonnali és mindenható vizsgálat" (Farrell és Hooker, 2013, p.692).

A DS gyökerei a müszaki tudományok területére nyúlnak vissza, és olyan problémákra keresi a választ, amelyek eseténben sem a problémákat, sem az azokra adható válaszokat nem lehet jól definiáltan meghatározni, és általában számos puha tényező befolyásolja ezeket (pl. kreativitás, csapatmunka). A DS alapvetően a „good enough”, a „müködő” megoldást keresi, amely folyamatosan javítható (Rodgers és Yee, 2014). A megközelítés szerint egy tudományos kutatást a gyakorlati következményei alapján lehet értékelni (Hevner és Chatterjee, 2010). Myers és Venable összehasonlításképpen az informatikai kutatások terén népszerü viselkedéstudományi megközelítéshez képest határozza meg a DS lényegét, mely szerint az ilyen típusú kutatások alapvető célja, hogy új technológiát vagy terméket hozzanak létre, amelyek „megváltoztathatják” a világot. Érdemes megemlíteni Margolin (2002) meglátásait, aki a müszaki, tervezői irányból hasonló folyamtokról és szempontokról ír, de „projektorientált kutatásnak” nevezi a megközelítést. Itt a sikeres termékfejlesztésnek egyaránt része az alapvető szakirodalom ismerete, és a különböző tudományterületek, szakértők integrált közös munkája. A szerző a siker alatt kifejezetten piaci sikert ért. Az eredménytermékek nem nagy elméletekből fakadnak, hanem a különböző szakértők közös munkájából: a „legfőbb célkitüzés ..., hogy a különböző tudományágakból összegyüjtött tudás a használati tárgyak tervezésében hasznosuljon.” (Margolin, 2014, p.53) A fenti szemléletet kiegészítve, érdemes megemlíteni a Design Thinking (DT) területét, amelynek számos fontos üzente van az e-learning tananyagfejlesztések tekintetében is: emberközpontú megoldások keresése, komplex problémák átvilágítása, a problémamegoldása folyamatos iterációk sorozata. A DT részletei a melléklet 6.1. fejezetben találhatók. 


\subsubsection{A kutatás szigora - módszertani kihívások, kritika és a legfontosabb szempontok}

A DSR során az iteratív megközelítés igen fontos, és sok esetben a sikeres, innovatív termék - esetünkben az e-learning tananyagok - e folyamatos vizsgálódás és a vizsgálatokra adott válaszok eredményeinek visszacsatolásának köszönhetően jön létre. Ez a szemlélet sok elemében találkozik a nyilt-innováció 2.0 Martin Curley és Bror Salmelin (2017) által megfogalmazott javaslatával, amely kiindulási alapként az európai innovációt kívánta serkenteni, egy a kísérletezésen alapuló, egészen Schumpeter „teremtő rombolás” gondoláig visszanyúló modellel. E szerint az innováció az érintettek minél szélesebb körü bevonásával, a folyamatos kísérletezéssel, és általánosan nagy fokú nyitottsággal érhető el. Többek között hangsúlyozni érdemes három gyors szempontot, a startup világból ismert elvek szerint: (1.) gyors cselekvés árán jusson el egy termék akár (2.) gyors bukáshoz, vagy siker esetén a (3.) gyors növekedéshez. (Herselman és Botha, 2015; Curley és Salmelin, 2017). Ez az elv és a nyitott innováció is számos kritikát is kapott az elmúlt évek során (Banks, 2016; Kelley, 2012; Fallon, 2016; Birkinshaw et al., 2010). Ennek oka a szigorú, tudományos megközelítés hiánya, hogy nem az iteratív és sokat kísérletező folyamatba épülnek be a fenti „gyors és innovatív” szempontok, hanem pont a DSR szigorú kereteitől függetlenül, önmagukban állnak.

A fentiek alapján egyszerü lenne úgy tekinteni a DS-re, mint ami a gyakorlati megközelítés mentén mellőzi a tudományos igényességet, ennek pontosításához Juhani livari (2007) két fontos meglátását szükséges kiemelni: A végeredmény lehet azonos a két megközelítés esetében (pl. egy termék), de az egyszerü gyakorlati megvalósitást és a DS alapú megvalósitást az különbözteti meg, hogy a DS estében (1.) tudományos igényességű a termék értékelése, minősítése és (2.) a DS kutatásnál nem csak a fejlesztések értékelése szempont, hanem az is, hogy a kutatás új termékek fejlesztése irányába tereljen. Fontos, hogy maga a termék fejlesztésének folyamata is egy szigorú kutatási keretben történjen.

A DS kutatások nézőpontja a meglévő környezeti tényezők, a ,jól bejáratott” folyamatok, az ismerős struktúrák felülvizsgálatára, megkérdőjelezésére bíztat, lehetőséget kínálva arra, hogy párba állítsuk a szigorú kutatási elveket és a gyakorlati életből vett problémákra adandó, gyakorlat-orientált válaszokat. Az új termékek, az új tudás „készítése” során, e környezeti elemek újra értelmezése, átalakítása, 
felülvizsgálata része lesz magának a kutatási és termékfejlesztési folyamatnak (Herselman és Botha, 2015). Fontos továbbá, hogy a DSR közelebb hozza a kutatókat és a szakértő felhasználókat (Gallupe, 2007). Amennyiben a vizsgálódás fókuszát az oktatás világára fordítjuk, úgy láthatjuk azt is, hogy ezen a területen is van hatása a design szemléletnek, többek között a „laboratóriumi körülmények” elvetése, a gyakorlatorientált kutatási logika erösödése mentén (Burkhardt és Schoenfeld, 2003). E jelenséget igen fontosnak tartottam kiemelni, hiszen jelen disszertáció is határterületen mozog, de nem fókusza e megközelítések részletes kibontása. Azonban az érdeklődők számára számos további szakirodalmi forrás (Collins, 1992; Steffe és Thompson, 2000; Cobb et al., 2003; Burkhardt és Schoenfeld, 2003; Prediger et al., 2015 ) áll rendelkezésére, amelyek ezt a területet vizsgálják.

Maga a DSR is fontosnak tartja, hogy kritikusan közelítsük meg a kutatás egyes elemeit. Ennek tükrében jogosnak tartom, hogy magával a DSR-rel kapcsolatosan is bemutassam a szakirodalomban található fenntartásokat, pozitív kritikákat. A kritikusok alapvető problémaként tekintenek a DSR túlzottan gyakorlatias nézőpontjára, és sok esetben hiányolják a teóriaalkotó képességét, illetve nem kidolgozott folyamatként tekintenek rá. Magának a design folyamatnak köszönhetően egyfelöl előfordulhat, hogy nem az eredeti felvetések vizsgálatával végződik a kutatás (vagy maga a termék konstruálása). Másfelől a DSR sajátos nyelvezetet alkalmaz (ez lehet pl. vizuális), amely gátja lehet a közös megértésnek, pl. az „elvetemült problémák” esetében, amelyek - már definíció szerint - sem kezelhetők átláthatóan (Zimmerman et al., 2010; Cobb et al., 2016).

\subsubsection{A kutatások csoportosítása - avagy mi lehet ebből az egészből?}

A DS kutatásokat több dimenzió szerint osztályozhatjuk. Ezek közül ez egyik a generalizálási szemszög, amely alapján a DSR lehet gyakorlat vagy elmélet-vezérelt. Egy másik nézőpont az eredményre tekint, amely szerint a DSR lehet termék vagy folyamat-központú (Gleasure, 2013). Az e-learning tananyagfejlesztés területre inkább a jellemző a gyakorlati és termék központú szemszög. A DSR további jellemzői az alábbiak: a gyakorlat vezérelt és inkább termékközpontú kutatások a termék hasznosságát emelik ki, míg az elmélet-vezérelt és folyamat-központú kutatások az általános jellegzetességeket vizsgálja, hogy a termék milyen módon old meg egy általánosabb problémát. Az eredmény szempontjából a pragmatikus, gyakorlat 
vezérelt kutatások „azonosított problémákat, kezdetleges tervezési elveket és szabályokat" (Gleasure, 2013, p.2) pl. bevezetési folyamatok, modelleket, technológiai szabályokat nyújtanak, míg az elmélet-vezérelt kutatások közepesen vagy igen részletes kidolgozott elméleteket prezentálnak (Gregor és Hevner, 2013; Gleasure, 2013). Az ICT irányából nézve egy terméket, pl. egy e-learning tananyagot, olyan alkalmazásként lehet definiálni, amelyet nem csak azért hoztunk létre, hogy egy speciális oktatási, képzési feladatot ellássunk, hanem beágyazzuk a vállalati környezetbe, a vállalat müködésébe, munkavállalói elkötelezettséget és hatékonyságot növeljünk (Benbasat és Zmud, 2003). Maga a termék a DS megközelítés szerint végeredményképp lehet akár egy koncepció, egy módszer, egy modell, egy elmélet, konstrukció vagy ezek bizonyítéka (Herselman és Botha, 2015). Az eredmény, a termék esetében első körben azt szükséges meghatározni, hogy milyen típusú a meglévő ismeretek vonatkozásában, milyen hozzájárulást ad. A tipizálást a 5. ábrán mutatom be.

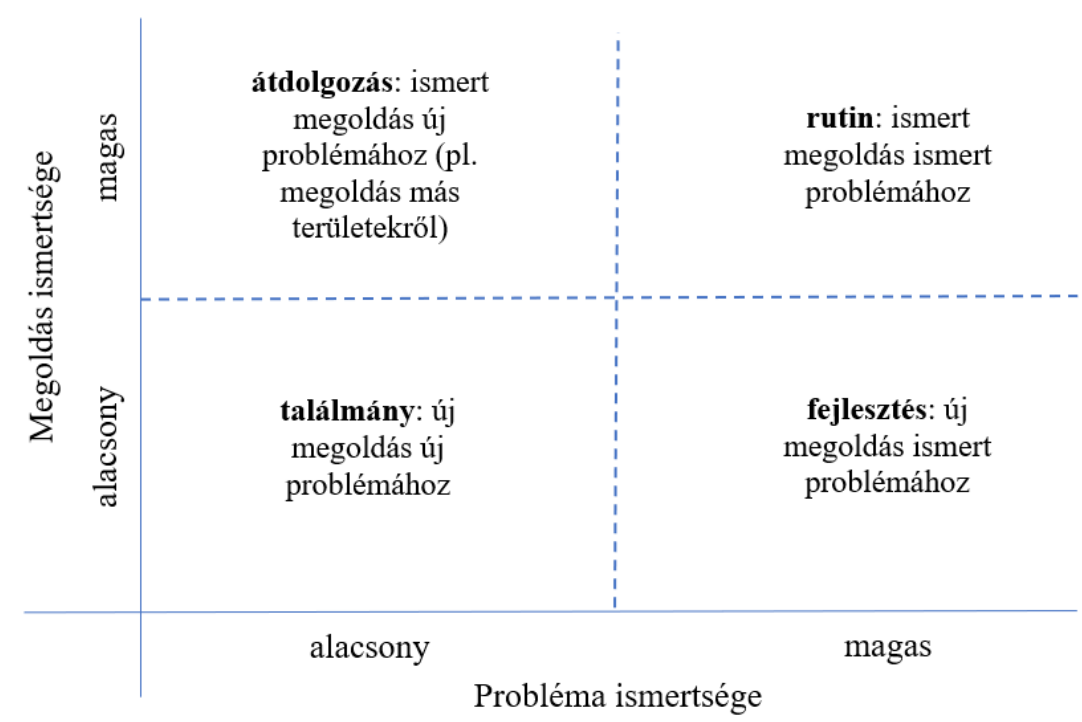

\section{5. ábra-DSR tudáshozzájárulás keretrendszer (Vaishnavi és Kuechler, 2004) alapján (saját ábra} 2018)

Amennyiben az eredmény tekintetében magas szinten ismert a megoldás és probléma, úgy rutinszerű tervezésről (routine design) van szó, abban az esetben ha mindkét szempont szerint alacsony, úgy találmánynak (invention) tekinthető, amely esetében alacsony az általánosítható tudás és az elvonatkoztatás lehetősége. Ha inkább az egyik vagy másik irányba tolódik a tipizálás, akkor magas szintü általánosításra és elvonatkoztatásra is van lehetőség, amely esetben a megoldás ismert, akkor átdolgozásról (adaptation), míg ha inkább a probléma ismert, akkor erre az 
eredményre fejlesztésként (improvement) tekinthetünk rá (Vaishnavi és Kuechler, 2004).

A DSR (fent ismertetett) hét irányelvét az alábbiak szerint kívánom érvényesíteni a disszertációban.

Irányelv

1. Tervezés, mint termék

2. Releváns probléma

3. Értékelés

7. Kutatás kommunikációja

\section{Disszertáció megfeleltetés}

A kutatás egyik eredménycélja, egy általános folyamatmodell az elearning tananyagfejlesztés tekintetében. Lásd 3.3 fejezet.

A releváns üzleti problémákat a disszertáció egy külön fejezetében tárom fel szisztematikusan. Lásd 3.2 fejezet.

A disszertáció része a fejlesztések értékelésének elemzése. Lásd 3.4.3 fejezet.

A problémák azonosítását követően, azokat problématérkép formában ábrázolni kívánom, az e-learning tananyagok fejlesztési folyamatának leírása világos és egyértelmüen követhető eredménytermék lesz, míg az értékelések elemzése pedig a jelentős elemszámú kutatási forrásnak köszönhetően igen értékes tartalom. Lásd 3.3 és 3.4 fejezetek.

A háttér tekintetében az esettanulmány, az akciókutatás, a megfigyelés és a mélyinterjúk módszertani elemeit kívánom alkalmazni, a DSR szigorú keretei között. A módszertani keretekről részletesen: 1.6 és 1.7 fejezetek.

A problémák szisztematikus azonosítása, és azokra adható válaszkeresés iteratív és akciókutatásban fakadó alapjai biztosítják a kutatási környezetből érkező folyamatos visszacsatolást, kapcsolódást. Lásd 3.2 fejezet.

Problématérkép ábrázolása, a tananyagfejlesztés folyamatának leírása, grafikus megjelenítése, a szövegelemzési eredmények vizualizálása mind-mind olyan eszköz, amely a megértést és az eredmények kommunikációját kívánják segíteni.

3. táblázat - A DSR hét irányelvének tervezett kapcsolódása (saját táblázat 2019)

A kutatás generalizálási szempontból gyakorlati és eredményét tekintve inkább folyamat központú. A folytatásban az egyes eredmények kapcsán meg kívánom határozni az előző fejezet csoportosítása alapján azok helyét az DS kutatások között. Az előzőekben is sokat idézett Hevner és társai (2010) nem csak a DS kutatás kapcsán tettek a 2000-es évek során döntő megállapításokat, hanem további, a kutatás során alkalmazható megoldásokat is mutattak be. Ezek között megtalálható egyfelöl egy nyolc elemű ellenőrzőlista, amely biztosítja az alapvető DS kutatási szempontok érvényesülését, és lehetőséget teremt a kutatás értékelésére. Másfelől pedig bemutatták a DSR hármas kutatási ciklusát. E szempontrendszert és kutatási ciklus részleteit a melléklet 6.2 fejezete tartalmazza. Ezek, mint a kutatást támogató keretként tekintek, 
elsősorban iránymutatásként. Másodsorban azonban a teljes kutatás értékelése során fontosnak tartom, hogy az itt megfogalmazott kérdésekre is választ tudjak adni a disszertáció lezáró szakaszában (4. fejezet).

\subsection{Akciókutatás és esettanulmány - a disszertáció hátterében „meghúzódó” kutatásmódszertani startégiáról, szemléletről és a miértekről}

\subsubsection{Részletesen az akciókutatási stratégiáról - cél a problémák megoldása}

A DSR keretek és irányelvek (lásd 1.5.3 fejezet hét irányelve) mellett a disszertáció kutatásai nagy mértékben támaszkodnak az AR szempontjaira, így ennek fényében a folytatásban bemutatom az AR lényeges tartalmi elemeit. Az AR-t is sok irányból definiálja a tudományos közösség. A társadalomtudományokban legtöbb esetben Rapoport (1970) definíciója, a valós gondok pozitív megváltoztatásának igényével számít mérvadónak. Én Hilary Bradbury-Huanggal (2010) értve egyet úgy fogalmaznék, hogy az akciókutatás során fontosabbak a gyakorlati tényezők azonosítás és elemzése, mint a megvalósulás mögött húzódó elméletek vizsgálata, igazolása, elvetése stb. Az AR lefolyása éppen ezért akár nehezen összeegyeztethető vizsgálódási folyamatokat is jelenthet, és eszményképe Kurt Lewin-től ered, amely szerint akkor lehet megérteni valamit, ha változtatunk rajta, és aktívan részt is veszünk ebben folyamatban (Adelman, 1993). Cooper és Argyris nyomán Kaplan (1998) írta le az innováció akciókutatási ciklusát, amely jól mutatja meg a folyamatos visszacsatolásokon alapuló és „végtelen” ciklusként jellemezhető kutatási folyamatot. Ezt a folyamatot maga is a menedzsment tudományok területén alkalmazta, megfigyelve, dokumentálva, szakértőkkel egyeztetve a részfolyamatokat, miközben ezeket tanította és aktív diskurzust folytatott róluk, cikkeket és könyveket írt. Ezt követően az így felépített új elveket beépítette új szervezetek esetében, és a korábbi tapasztalatok mentén újra kezdte a ciklust, megfigyelve és dokumentálva a megváltozott folyamatot. Az AR alkalmazása az információrendszerek területén talán legalaposabban Baskersville önállóan (2001, 1999, 1997) és munkatársaival közösen (1996, 1998; 1999; 2004) dolgozta fel számos cikkben. Jelen disszertáció számára fontos gondolatokat egyfelől a legtöbbször Baskersville-től idézett, de valójában Susman és Evered (1978) által leírt, öt fázisból álló ciklus jelenti, amely ciklus a következő: (1.) diagnózis, (2.) akció tervezés, (3.) cselekvés, (4.) kiértékelés, (5.) eredmény meghatározása a kliens és a kutató vonatkozásában. Másfelől ugyanilyen 
fontos a ciklus szempontjából, a valóban Baskerville és Myers (2004) által összefoglalt négy akciókutatási feltétel:

1. Pierce elve: a következmények határozzák meg az ember felfogását. Ez az AR pragmatikus mivoltára mutat rá, egyfelől hangsúlyozva, hogy a következtetések összessége alkotja meg koncepció jelentését. Másfelől pedig azt mondja Pierce, hogy egy intellektuális koncepció megértéséhez figyelembe kell venni annak praktikus következményeit. Ezek alapján mondja Baskerville, hogy szükséges a cselekvés céljának meghatározását. Az elméletnek világosnak kell lennie már a cselekvés előtt is, ellenkező esetben lehetséges, hogy a cselekvés céltalan és értelmetlen lesz.

2. James elve: „Az igazság a praktikus eredményekben ölt testet.” (Baskerville és Myers, 2004, p.331) - mely az AR gyakorlatiasságának egy újabb alátámasztása. Vagyis Baskerville feltétele, hogy gyakorlati cselekvést is tartalmaznia kell a folyamatnak.

3. Dewey elve: az a kontrollált vizsgálat, melyben a cselekvést vegyítjük a racionális gondolatokkal, mely feltétel alapján az elméletet a cselekvés gyakorlati eredményei alapján kell formálni.

4. Mead elve: az emberi felfogás szociális visszatükrözödés, és az emberi cselekvés társadalmi környezetben értelmezhetö. E feltétel azt jelenti, hogy társadalmi környezetbe kell helyezni a cselekvést és az érvelést, a megfigyelő legyen része a megfigyelt területnek. (Baskerville és Myers, 2004)

A fenti feltételek és a több szerző által is kifejtett ciklikusság számomra az e-learning tananyagok fejlesztési folyamatának elemzése és megértése során kiemelten fontosnak bizonyult. Maga a disszertáció is a saját - nehezen számszerüsíthető - ciklusaim egyikének dokumentálása és publikálása.

Három szempont alapján lehet egy vizsgálódást akciókutatásként leírni: (1.) a kutatás tárgya egy változtatásra szoruló gyakorlati, közösségi kérdés, probléma; (2.) a kutató részese a folyamatoknak; (3.) a kutatás a fenti ciklikusság szerint müködik: tervez, cselekszik, megfigyel, visszacsatol. Ezt dokumentálja szisztematikusan Swann (2002). Az AR ciklikusság és elemeiből következtetve az akciókutatás könnyen tekinthető egy tervezési (design) folyamatnak is. Az akciókutatás stratégiai célja, hogy megoldjon egy problémát és hatásos megoldási iránymutatásokat is adjon (Denscombe, 2010). Hilary Bradbury-Huang (2010) is rámutat arra, ami meglátásom szerint ugyancsak 
fontos, hogy az akciókutatás lehetőséget ad arra, hogy a kifejezetten gyakorlati kérdések is tudományos igényességgel mérettessenek meg, de emellett a tudomány is haszonélvezője az ilyen vizsgálódásoknak. A kutató a gyakorlatban is releváns kérdésekkel foglalkozhat, és ráirányítja a figyelmet olyan összefüggésekre, amelyeknek gyakorlati és nem csak elméleti hatásai is vannak vagy lehetnek.

Jelen disszertáció folytatásában az akciókutatás az előzőekben részletezett szempontjai és megközelítéseit alkalmazom, és a DSR kutatás szigora, valamint az általa biztosított keretek mentén folytatom a tudomány területén a gyakorlatban gyökerező problémákra adandó válaszok keresését. Az AR és a DSR szemléletének közelségét Pertti Järvinen (2007) hét szempont szerint írja le, amelyek az alábbiak:

1. hasznossági kritérium;

2. gyakorlati dolgok megváltozása;

3. központi elemek: cselekvés és értékelés;

4. együttmüködés a résztvevőkkel és helyi problémák megoldása;

5. problémák megoldása új megoldás konstruálása, fejlesztése vagy módosítása által;

6. aktív kutatói részvétel;

7. ismeret ciklus (létrehozás, használat, értékelés).

A jelen disszertációban felvázolt több rétegű kutatási megközelítésben a két szemlélet kompatibilitásának köszönhetően a DSR szigorú kereteket, míg az AR érett módszertani lehetőségeket ad (Cole et al., 2005).

Az akciókutatás fontos tulajdonsága, hogy szisztematikusa feldolgozva, kritikus szemmel írja le a megfigyelt eseményeket, még ha a végeredmény tartalmaz szubjektív és személyes tartalmat is. Ehhez a szemléletmódhoz illeszkedik jól az esettanulmányok „mélységi megfigyelő” hozzáállása, amely adott esetben innovatív, új megoldásokat is eredményezhet (Swann, 2002).

\subsubsection{Az esettanulmány kutatási stratégiáról - cél a problémák mély megismerése}

Az AR mellett a kutatási stratégiaként a Case Study (CS) azaz esettanulmány megközelítést is alkalmaztam a disszertáció gerincét adó adatgyüjtés során. Az esttanulmány módszer egy adott esettel kapcsolatos mélységi vizsgálatot tesz lehetővé, amely leginkább a „hogy” és „miért” kérdésekre keresi a választ. Leginkább azokban 
az esetekben javasolt alkalmazni, amikor a kutatás központi kérdése nem választható le egyértelműen a környezettől és annak hatásaitól. Sok esetben a kutatónak kis hatása van az eseményekre, és az esettanulmányokat - oktatási területen - programok értékelésére használják (Yin, 1984; Babbie, 2008; Yazan, 2015). Stake (1995) négy szempontot ír le:

1. Az esettanulmány gyakran ,holisztikus”, vagyis a megfigyelés tárgya és a környezet közötti összefüggéseket is vizsgálja a kutató.

2. Az esettanulmány „empirikus”, vagyis a kutató a saját tapasztalatot szerez.

3. Az esettanulmány „tolmácsoló”, hiszen a kutató elsősorban a saját megfigyeléseire támaszkodik.

4. Az esettanulmány „empatikus”, mert bizonyos határokon átnyúlva értelmezi az eseményeket. (Yazan, 2015)

A határokon átnyúlás nem minden szerző esetében azonos. Merriam (1998) kifejezetten egy adott helyzetre, jól körül határolható keretek kezeli csak az esettanulmányokat, és kifejezetten nem hipotézis tesztelésre, hanem értelmezésre és felfedezésre kívánják alkalmazni (Noor, 2008; Yazan, 2015).

Számos más tudományterületen is alkalmazzák az esettanulmány módszert többek között az üzleti kutatástól, a politikatudományon át, az archeológián keresztül, az oktatás és az informatika és természetesen az e-learning területén is. Lásd még (Lee, 1989; Gerring, 2006; Liaw, 2008; Brady et al., 2010). A tananyagfejlesztés szerteágazó tevékenység, amelynek minden esetben része egy komoly ICT fejlesztés is, amely technológiai (lásd pl. flash vs. html5 szabványok) és arculati (lásd webdesign trendek) részei is egy dinamikusan változó környezetben értelmezhető gyakorlatorientált kérdéskörök, amelyek remek táptalajai az esettanulmány szempontú elemzésnek (Benbasat et al., 1987). A CS megközelítés esetében elönyként írható le a mélységi vizsgálódás lehetősége, a széles nézőpont alkalmazása és az összefüggések jó azonosíthatósága (Babbie, 2008). Hátránya, hogy nincsenek jól meghatározott eljárásrendek, tervezési és kivitelezési megoldások, amelyek alapján felépíthető egyegy kutatás (Yazan, 2015).

Jelen disszertációban a mintába felvett projektek sokszínüsége okán alkalmaztam több fajta kutatási stratégiát, és a két megközelítés közül mindig az adott projekthez jobban illeszkedő módszertani megközelítést választottam. A melléklet 6.4 fejezetében összehasonlítóm az AR és CS kutatási stratégiákat. 


\subsection{Háromszögelő vizsgálatok - röviden a dolgozat érvényességével kapcsolatosan}

A disszertációhoz kapcsolód kutatások esetében lényeges módszertani megközelítés, hogy háromszögelő vizsgálatokkal érvényesítem az egyes megfigyeléseket, eredményeket. Többségében különböző kvalitatív módszereket használok, amelyek segítségével más-más nézőpontok szerint tudok megközelíteni egy-egy kérdést. Miles és Huberman nyomán a kutatás autentikusságát négy forma vizsgálatával illetve alkalmazásával növelhetjük (Flick, 2004; Sántha, 2007):

1. az adatok háromszögelése, amikor különböző idöben, térben és más személyektől érkeznek az adatok;

2. a megfigyelök háromszögelése, amely esetében más-más interjúalanyok bevonása történik meg ugyanazzal a kérdéssel kapcsolatosan.

3. az elméletek háromszögelése, amely során különböző teóriák ütközhetnek.

4. a módszertanok háromszögelése, amikor különböző eljárásokat állít a kutató egymással szembe.

Flick nyomán a szerző így fogalmaz: a különböző triangulációs formákat „ötvöző, szisztematikus perspektív trianguláció meghatározását is indokolt [..] Ennek alkalmazása sok tekintetben előnyös, hiszen a kvalitatív kutatási perspektívákat kombinálva összeadódnak azok erősségei, valamint határaik is jobban kirajzolódnak és megszilárdulnak" (Sántha, 2007, p.172).

A disszertáció elkészítése során elsősorban a második és a negyedik forma érvényesül. Egyik oldalról törekszem, hogy a saját megfigyelések mellett, félig strukturált interjúk eredményeit is felhasználjam, valamint - ahol a kutatási kérdés és a -körülmények lehetővé teszik ott pedig - az irodalom feldolgozás mellett pl. szövegbányászati módszertanokat is beemeljek.

A témakör feldolgozásához azért választottam a félig strukturált interjú formáját a sok lehetséges interjú-technika közül, mert irányítottan vagyok kíváncsi az alanyok véleményére, de a szakmai tudásom és a megfigyelésekből fakadó korábbi ismereteknek köszönhetően az interjúk során tudom pontosítani a kérdéseket. Az érdekesebbek részek esetén mélységi kérdésekkel alakítom a beszélgetést, illetve addig fel nem merült témák is felszínre kerülhetnek, így szélesítve az interjú által adott 
adatok, ismeretek körét. A félig strukturált interjúk kötetlenek, kódolása nem szükséges, ám jegyzetek készítése javasolt (Lengyelné Molnár, 2013).

A megfigyelés, mint kutatási technika elsősorban a témához füződő személyes kapcsolat okán releváns módszer, hiszen a kutatási időszak során számos releváns projektben vettem részét, és figyeltem meg az e-learning tananyagok fejlesztését.

A teljes kutatásra tekintve sok esetben alkalmaztam a megfigyelést, mint kutatásmódszertani technikát. „A megfigyelés nem más, mint irányított észlelés, amelynek alapján valamilyen megállapításra jutunk.” (Szokolszky, 2004, p.250). E folyamat megtervezett, céltudatos és van valamilyen eredményelvárás is. Általánosan elmondható, hogy feltárni és leírni lehet által a megfigyelteket. A kulturális antropológiában az etnográfiai terepmunka egyik alapvető eszköze a megfigyelés, amelyben a kutató részese lesz a megfigyeltek csoportjának. Jelen disszertációra a résztvevő-strukturálatlan típusú megfigyelés lesz jellemző, amely egy kötetlen megfigyelési forma, kevésbé behatárolt előzetes tervek által, és épp ezért iteratív folyamatként lehetőséget ad, hogy a későbbi megfigyelésekbe beépítsük a korábbiak eredményeit (Savage, 2000; Szokolszky, 2004).

\subsection{Kutatási kérdések - relevancia, csoportosítás és az adatok azonosítása}

Az irodalom feldolgozása a 1.5-es fejezetében részletesen kifejtésre került, ott bemutattam a DS-t és annak kutatás elméleti metódusát. Ezek alapján a kutatások (kutatási kérdések) az 6. ábrán látható tengelyek mentén jellemezhetők.

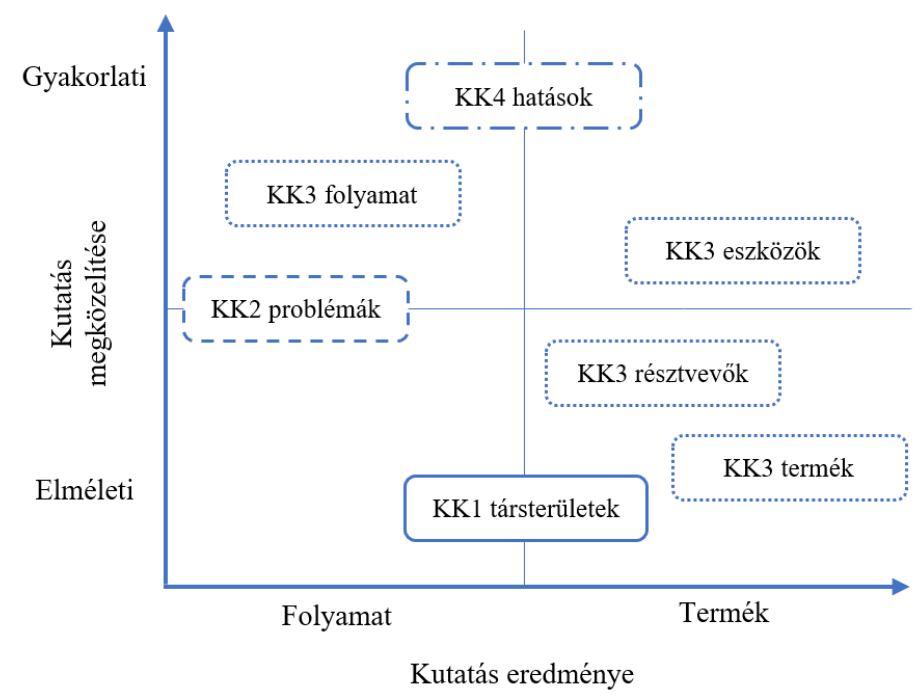

6. ábra - A kutatási kérdések (KKn) DSR kategóriák szerinti ábrázolása (saját ábra 2019) 
Az 6. ábrán is látható, hogy mind a folyamat, mind a termék esetében gyakorlati és elméleti területen jelentkező kérdéseket is vizsgálok. A folyamat jelen disszertáció esetében egyértelműen a tananyagfejlesztés komplex, sok résztvevős folyamatát jelenti, a termék pedig egy e-learning tananyag (lásd 3.3.2 fejezet), amelyet a meghatározott eszközökkel és technológiákkal lehet elöállítani.

A kutatási kérdések szervesen illeszkednek a DSR - 6. ábrán bemutatott - kereteihez. Míg az első két kutatási kérdés (KK1 és KK2) a probléma-felvetéshez, a harmadik kutatási kérdés (KK3) a megoldás konstruálásához, a negyedik kutatási kérdés (KK4) pedig az értékelése lépéséhez illeszkedik.

\section{Hogyan rendszerezhetők az e-learning ökoszisztéma elemzéséhez szükséges társterületek?}

A probléma-felvetéshez nélkülözhetetlennek tartom azt megvizsgálni, hogy a tananyagfejlesztések milyen tudományos környezetben zajlanak, azok milyen társterületek ismeretét feltételezik, és ezeknek milyen kapcsolódási pontjai vannak egymáshoz. Ez a vizsgálat, amelyet irodalomfeldolgozásra, saját megfigyelésekre és szövegelemzésre építek, jó alapot képez a problémafelvetés tudományos megalapozásához, annak koncepcionális elmélyítéséhez.

2. Milyen jellegzetes - nagy szervezetekre jellemző - problémák, illetve problémacsoportok megoldásában alkalmazható az e-learning tananyagfejlesztés?

A második kutatási kérdés célja, hogy azonosítani tudjam azokat a kereteket, amelyek között már olyan gyakorlati, komplex problémák azonosíthatók, amelyekre - az általános képzési tevékenységen belül - e-learning tananyagok fejlesztése (rész)megoldást kínál. A kutatás háttereként - a kutatások érvényességéhez a háromszögelő vizsgálatoknak (Sántha, 2007) megfelelően - irodalomfeldolgozást, mélyinterjúk eredményeit és a saját megfigyeléseimet (pl. gondolattérkép technika alkalmazásával) használom fel (Habók, 2009).

3. Hogyan jellemezhető és írható le az e-learning fejlesztés során kialakuló fejlesztési ökoszisztéma? 
A harmadik kutatási kérdés - és kiegészítő kérdései - a megoldás konstruálása szempontjából vizsgálják az e-learning tananyagfejlesztési folyamatot és annak eredménytermékeit. A folyamat, a termékek, a szerepek és az eszközök vizsgálatán keresztül keresem a választ a kérdésekre, amelyek mindegyike esetében szisztematikusan lefolytatott kvalitatív kutatásokra és szakértői mélyinterjúkra támaszkodom a szakirodalom feltárása mellett.

4. Milyen közvetlen és közvezetett eredményei, hatásai lehetnek egy kifejezetten a képernyő elốtti tanulásra fejlesztett, e-learning tananyag alapú vagy azokkal támogatott képzésnek?

E kutatási kérdéskör a DSR harmadik fázisa alapján a konstruált megoldások értékeléséhez kapcsolódik. Egyfelől egy-egy tananyagfejlesztés eredményeinek vizsgálatával, amelyekre szakértői interjúk és szövegbányászati kutatásokkal keresem a válaszokat. Másfelöl pedig a gyakorlati megfigyelések összefoglalására saját empirikus tapasztalataim feldolgozására, az interjúalanyok válaszainak elemzésére és a szakirodalom vizsgálatára támaszkodom. Míg megoldás konstruálása során a tananyagfejlesztés „bemeneti” (input) elemeit, magát a „folyamatot” (process) és a fejlesztés jól mérhető „termékeit” (output) vizsgáltam, addig e kutatási kérdések során az „eredményeket” (outcome) és azok tágabban értelmezett „hatásokait” (impact) kutatom (Millard et al., 2006; Parsons et al., 2013).

\subsection{Hipotézisek - sejtések és elvárások}

Az alábbiakban összefoglalom, hogy a fenti kutatási kérdésekkel összefüggésben milyen hipotéziseket állítottam fel.

H1.: Az irodalmi áttekintés alapján feltételezhető, hogy az e-learning tananyagfejlesztés ökoszisztémájának releváns társterületei három nagy csoportba rendszerezhetők. Az első a tananyagfejlesztéshez, mint projekthez kapcsolódó menedzsment ismeretek pl. vízesés modell, agilis elvek. A második a tananyagfejlesztés során alkalmazott módszertanok pl. konstruktivizmus, webfejlesztési elvek. A harmadik pedig a szervezeti tudásához kapcsolódó tudományos területek pl. tudásmenedzsment.

H2.: Amennyiben a hagyományos, szük megközelítéssel szemben, az e-learning tananyagfejlesztésre nemcsak mint tanagyagkészítésre tekintünk, hanem tágan 
értelmezzük, mint egy ökoszisztéma, úgy az ún. elvetemült (wicked) szervezeti problémák egy része is kezelhető a nagyvállalati emberi eröforrás menedzsment területen.

H3.: Feltételezésem szerint az e-learning tananyagfejlesztés ökoszisztéma megközelítése módszertanilag is támogatható. Ebben a vonatkozásban a design megközelités keretrendszerében, tetszőleges belépési ponton indítható tervezési ciklusokkal, folyamatos visszacsatolásokkal tudunk eredményeket elérni.

H4.: Feltételezem, hogy empirikusan alátámasztható az, hogy az e-learning tananyagfejlesztés tág - ún. ökoszisztéma szemléletü - megközelítésével új közvetlen és közvetett eredményeket és hatásokat tudok azonosítani, a szüken értelmezett tananyagfejlesztési eredményeken túlmenően.

H5.: Elvárásként azt is kitüztem a kutatás céljaként, hogy az elméleti eredmények összegzéseként kialakítsak egy koncepcionális és gyakorlati útmutatót is, amely rendszerezi az eredményeket vezetői ajánlások formájában. 


\section{IRODALOMFELDOLGOZÁS, ELMÉLETI HÁTTÉR - ALAPVETŐ TERÜLETEK, TÉMÁK ÉS FOGALMAK}

Az alábbiakban összefoglalom és definiálom azt a fogalomkészletet, amely a kutatási tartalmak kibontásának nem a módszertani, hanem az e-learning szakmai alapjait jelentik, és segítséget nyújtanak a disszertáció további értelmezésében.

\subsection{E-learning „fogalomtár” - kutatáshoz nélkülözhetetlen fogalmak magyarázata és a szakszavak összefoglalása}

Jelen disszertáció nem kíván definíciós lexikonná, vagy az e-learninghez kapcsolódó szakszavak gyüjteményévé válni, azonban a folytatáshoz nélkülözhetetlen, hogy áttekintsem azokat az alapvető „e-learninges” szakkifejezések, amelyek meghatározók lesznek jelen kutatás során. A dolgozat keretein túlmutat a különböző definíciós nézetek és vélemények összevetése, elemzése, éppen ezért a folytatásban azokat a meghatározásokat ismertetem, amelyek tükrözik a saját szakmai véleményemet is.

Maga az „e-learning” (elektronikus tanulás) kifejezés szorosan kapcsolódik a távoktatás (távtanulás, távoktatás stb.) fogalmához, amely gyökerei a '70-es évekre nyúlnak vissza. „Az e-learning magába foglalja a távoktatás minden ismérvét, ugyanakkor az interaktivitást elektronikus kommunikációs eszközökkel biztosítja." (Harangi és Kelner, 2003, p.7). A távoktatást Kovács Irma (1996) klasszikus irodalmi idézete jól határozza meg: „A távoktatás fedi mind a tanulási tevékenység, mind pedig a tanítási (oktatási-nevelési) tevékenység összes elemét, amelyeket a távolság (-ok) legyőzésének igényével létrehozott igen dinamikus és komplex pedagógiai kapcsolategyüttes füz össze egyetlen közös folyamattá.” (Kovács, 1996, p.34) Ugyanitt meghatározásra kerülnek a legfontosabb ismérvek is:

- bármikor, bárhonnan elérhető,

- más (új) tanulói és oktatói szerepek,

- dinamikus tanulási-tanítási közeg,

- önálló tanulás,

- sokszínű kommunikáció (elektronikus csatornák, tanuló-tanuló interakció stb.),

- csoportos oktatási lehetőségek,

„... A távoktatás megszervezése hasonlít az ipari folyamatok megszervezéséhez.” (Kovács, 1996, p.44). A több, mint 20 éve megfogalmazott alapvetések a mai napig 
érvényesek, kiegészítést hozott a széleskörü a multimédiás (audiovizuális) lehetőségek becsatornázása, amely esetében a látható és hallgató verbális és nonverbális kommunikációs elemek is segíti a tanulást, tanítást (Csoma, 2003). Mindemellett nem összekeverendő a két fogalom, az e-learning kiegészülhet olyan elemekkel, amelyek túlmutatnak a fentieken elsősorban a tanári szerepek megváltozásának köszönhetően. Összességében olyan tanulási, tanítási és ezek szervezési feladatainak összességéről beszélhetünk az „e-learning” esetében, amely ICT eszközök (elsősorban internet vagy intranet) alkalmazásával valósul meg, és fontos, hogy az informális és formális elemek is ötvözhetők a tanulási, tanítási folyamatban (Kovács, 2011; Zhang és Nunamaker, 2003). A fogalmi megközelítésekre tekintve láthatjuk ahogy a technológia interaktív módon összekapcsolja az oktatókat a tanulókkal a tartalmak és eszközök által. A folyamat esetében kiemelten fontos a didaktikai tervezés (optimalizálás), a modularitás és a rendszerszemlélet (környezetbe illesztés) (Zhang, 2005; Komenczi, 2006). Az elearning három „klasszikus” terület metszeteként is értelmezhető:

1. Számítógéppel segített tanulás (computer based learning - CBL), ahol megvalósul az adattárolás, -feldolgozás, multimédiás tartalmak és a virtualitás;

2. Hálózat alapú tanulás (web based learning - WBL), amely kiterjesztett, nyitott információszerzést és kommunikációt jelent;

3. Távoktatás (distance leraning - DL), amely alapján időben és térben bármikor elérhetők a tartalmak, tanuló központú az oktatás és önirányított a tanulás (Komenczi, 2006).

Egyes szerzők az oktatás forradalmaként tekintetettek a 2000-es évek elején az elearningre (Galagan, 2000; Zhang és Nunamaker, 2003), amely megfogalmazásában túlzónak tünhetett, de közel 20 év távlatából valóban jelentősnek mondható a már lefolyt és a jövőben várható változás. Az online tanulás világa az alábbiakban azonosított három alapvető változást hozta:

1. „filozófiai” váltás az objektivizmustól a konstruktivizmus felé;

2. teoretikus váltás az oktatás behaviorizmus nézete felől a szocio-kognitív irányába;

3. pedagógiai váltás az utasítás alapú oktatástól az együttmüködésen alapuló oktatás felé." (Shea, 2006, p.35)

Az e-learning elönyei: 
- Bármikor, bárhonnan elérhető tartalom

- A tanuló a saját tempójában haladhat

- Sok esetben költséghatékony a tanulók számára (pl. nem kell utazni)

- Könnyen megosztható és újra meg újra elérhető a tartalom (lásd tartalomtárak).

- Interaktív és multimédiás lehetőségek

- Különböző tanítási-tanulási stratégiák, stílusok alakíthatók ki

- A tanulás mérhető (pl. eredményesség, ráfordítás stb.)

Az e-learning hátrányai:

- Azonnali visszajelzés hiánya vagy alacsony száma az aszinkron oktatási helyzetekben

- Informatikai ismereteket igényel

- A bevezetés költsége magas (lehet)

- A tényleges peer-to-peer aktivitás elérésnek magas az erőforrás igénye

- Könnyen összekeveredik az e-learning által az információ szerzés (olvasás) és a képzés (pl. tréning) $)^{1}$

- A rosszul bevezetett e-learning elveszi a felhasználók kedvét a tanulástól és az informatikai eszközöktől is.

A szakirodalom is a fentiekben találhatókhoz hasonló elönyöket gyüjt csokorba: a tanulás idejének és helyének szabad meghatározása, az oktatótól való időbeli függetlenség, az aszinkron haladás lehetősége, kérdések és elgondolások határtalan megfogalmazásának lehetősége, együttmüködési lehetőségek, a tanuló saját maga dönthet a hozzáférésről és egy örök klasszikus: az e-learning gazdaságosan kivitelezhető. A tanulás gyorsabb lehet, könnyebben frissíthető a tartalom, és nagy tömegeket is elérhet a tudásanyag (Capper, 2001; Cantoni et al., 2004; Bouhnik és Marcus, 2006; Sinclair et al., 2016). Illetve megemlítésre kerül a multimédiás tartalmak fontossága is, amely segíti a megértést és visszaemlékezést (Lee, 2010).

Gunasekaran (2002) nyomán Bondarouk és Ruël (2010) négy motivációt írnak le a szervezetek esetében:

\footnotetext{
${ }^{1}$ Elsősorban a rossz e-learninges implementációnak köszönhetően csak az információ átadás valósul meg, és a gyakorlási lehetőségek, a visszajelzés adása és a támogatás elmarad, amelyek mind-mind kulcs elemi lennének a hatékony tanulásnak.
} 
1. a tanulás minöségének javítása,

2. a tanuláshoz történő hozzáférés javítása,

3. képzési költségek csökkentése és

4. képzési programok költséghatékonyságának növelése.

Ennek kapcsán tapasztalatomhoz hasonló hátrányokról is számolnak be: mivel az induló költségek magasak, ezért alacsony lehet a menedzsment elkötelezettsége, azért is, mert egy hosszú távú befektetésről van szó (Bondarouk és Ruël, 2010).

\section{Meglátásom szerint a legfontosabb szempont, hogy az e-learning esetében az} oktató helyett a tanuló kerülhet a középpontba, amely egyszerre jelenti azt, hogy az oktató szerepét át kell alakítani (pl. sokkal inkább támogató, moderátori szerep kerül előtérbe), másfelől pedig a tanulók hozzáállása is megváltozhat. „Az átalakulás a tanítási paradigmáról a tanulás paradigmájára abból adódik, hogy az IT eszközök széleskörü használata tanulási hálózatokat és fogyasztói hozzáállást alakít ki. [...] Az e-learning pedig rendelkezik egy egyedi terméktulajdonsággal (unique selling point USP), ez a hozzáférhetőség. [...]" (Blass és Davis, 2003, p.229). A hozzáférhetőségnek két aspektusa van, az egyik a „klasszikusnak” tekinthető elearning előny, amely szerint bármikor, bárhonnan elérhető a tartalom. A másik pedig maga a tanulási élmény, amely ugyancsak elérhetővé válhat a tanulók számára, hiszen nem csak „olvasási élményről” kell a tanulásnak szólnia. Nagyon helyes Blassnak és Davisnek (2003) meglátása, mely szerint a meglévő, szövegalapú (és szöveg túlsúlyú) tananyagok egyszerü feltöltése az online térbe még nem jelent valódi e-learninget. A disszertáció egy későbbi szakaszában részletesen kifejtem (lásd 2.1.1 fejezet), hogy mit tekintek tanuló- és tartalomközpontú e-learning tananyagnak.

Főként a költségcsökkentésből fakadó „e-learningesítés” kapcsán, sok vállalati képzés esetében találkoztam azzal, hogy a menedzsment számára az e-learning egyenlő a már rég óta meglévő előadások (vagy szöveges anyagok) online térbe történő betöltésével. Fontos annak megértése, hogy az e-learning-re nem szabad úgy tekinteni, mint egyszerűen a meglévő ismeretek, tananyagok konvertálására a digitális térbe. A szakirodalomban jól dokumentált, hogy ez a hozzáállás nem megfelelő tartalmakat generál, és egy általános ellenérzést okoz a tanulókban (Mandinach, 2005; Dror, 2008). 
A nagyvállalatok esetében is megfigyelhető, hogy fontos tényező a költséghatékonyság, valamint a munkatársak számára a képzési lehetőségek biztosítása ilyen formában (Poór et al., 2016).

Az e-learning legtöbb esetben az aszinkron tanulásról szól, tehát elöre rögzített, leírt stb. tartalmakról beszélünk, ám számos e-learning megoldás létezik szinkron oktatási helyzetek kezelésére is. Jelen disszertáció fókuszában lévő tananyagfejlesztés az előbbi területen értelmezhető, ám fontos a megkülönböztetés, ráadásul a vállalkozások (egyébként nagyon helyesen) keverve alkalmazzák a módszereket. További „keverés”, hogy a képzések egymás mellett tartalmaznak online és jelenléti elemeket is. E kevert megközelítés az ún. blended (vagy hibrid) learning, amely az egyik legígéretesebb képzési irány, hiszen ötvözi a legjobb lehetőségeit a két iránynak: személyre szabható és differenciálható tartalom, miközben a tanuló határozhatja meg a haladási tempóját, idejét, kiegészül a tanulási élmény az oktatók személyes jelenlétén alapuló támogatásával. Fontos, hogy a blended learning esetében a jelenléti és online, technológiai környezet tudatosan van összekapcsolva. A blended learning újra gondolja és újra értelmezi a teljes tanítási, tanulási helyzetet (Garrison és Kanuka, 2004; T. Osguthorpe és Graham, 2003). A kevert képzések esetben kiemelendő azok pedagógia elönyei: a tanulási aktivitás emelkedése, a tanulók közötti együttmüködés erősítése, a tanuló központúság. További előnyök a képzések hozzáférhetőségének és rugalmasságának lehetőségei és a képzések költséghatékonyság (T. Osguthorpe és Graham, 2003). A blended learning hatékony és a tanulók által is preferált képzési forma (Margolis et al., 2017).

Welsh és munkatársai (2003) számost kutatás eredményeit elemezve az alábbi fontos meglátásokat tették, amelyekkel szakmai tapasztalatom is egybevág: (1.) valóban hatékonyabban lehet e-learning-es megoldásokkal tanulni; (2.) a képzések költsége valóban csökkenthető a digitális eszközök használata által, ha nagy a tanulók létszáma vagy sokszor megismétlésre kerül a kurzus vagy sok helyszínen szükséges oktatni; (3.) az opcionális kurzusokat sok esetben nem fejezik be a résztvevők, és sok esetben nem is szükséges teljes mértékben befejezni azokat, hiszen a részeiből is kinyerhető az igényelt tudás; (4.) összességében pedig a kutatások azt jelzik, hogy a digitális eszközökkel támogatott tanulási formák felé pozitívan állnak a tanulók, amennyiben sikerül a „zavaró” technikai problémákat feloldani. 
A fentiek alapvető információkat adhattak az e-learninggel kapcsolatosan, azonban fontosnak tartom lehatárolni, hogy mit is értek a folytatásban e-learning tananyag alatt. Saját meghatározásom szerint az e-learning tananyag nem csupán tartalom, hanem egy önállóan értelmezhető, modulárisan felépített, interaktív tanegység, amely amellett, hogy szabványos, interaktív és multimédiás tartalmakban gazdag, reflektálni képes a tanuló korábbi ismereteire és támogatja az egyéni tanulást, valamint visszajelzést is ad a résztvevő számára. Továbbá a „tananyag” adatokat szolgáltat legalább az előrehaladásról és a teljesítettségről. A ,jó” e-learning tananyag általam meghatározott jellemzőit a következő, 2.1.1 fejezetben fejtem ki részletesen.

Magát az e-learningben rejlő lehetőségeket már ennél egyszerübb megoldásokkal is meg lehet valósítani (pl. előadások rögzítésével), és sok szervezet számára már a meglévő tudás prezentációkká alakítása is nagy előrelépés, ezeket mégsem tekintem e-learning tananyagnak. Ezek a tananyagelemek mindössze „digitalizált tartalmak”, „elektronikusak”, de nem felelnek meg az e-learning by design elvének. A valódi elearning tananyagok tanulásra tervezett (pl. kerettörténetbe ágyazott, tanulótárssal kiegészített stb.), interaktív keretben több fajta, az adott ismerethez (információhoz, tudáselemhez stb.) módszertanilag legjobban illeszkedő tananyagelemböl (learning object - LO) épülnek fel. A szakirodalomban több klasszifikáció is elérhető (Wiley, 2000; Churchill, 2007), a folytatásban az alábbiakat tekintem LO-nak: szöveges, multimédiás tartalom (videó felvétel, kép, hang, kisfilm); minijáték (összetett interaktív feladat); tudásmérés és visszajelzés; szimulációs tartalom (szoftver vagy egyéb videóalapú interaktív tartalom); szakanyag.

Típus

Meghatározás

Szöveg

\begin{abstract}
A szöveges tartalom az alapja minden tananyagnak, mely videó tartalom esetében is biztosítja az indexelhetőséget (kereshetőséget), és a tudás alapvető átadására alkalmas. Fontos, hogy képernyő előtti tanulásra alkalmas szövegekről legyen szó, tehát nem klasszikus tankönyvi elemekről. E szöveges tartalmak megjelenítése interaktív formában is megvalósulhat (pl. kattintás után érhető elé mélyebb ismeret stb.).
\end{abstract}

\section{Megtekintési}

idö $^{2}$

3-5 perc

\footnotetext{
${ }^{2}$ Egy egységre eső javasolt megtekintési idő (pl. egyszeri elolvasás ideje, megnézés vagy meghallgatás, „végig kattintás” stb. ideje).
} 
Multimédia Multimédiás gyüjtőtartalomként hivatkozom minden 3-7 perc

illusztrációra, képre, hangra vagy videós tartalomra, legyen az képernyővideó, előadásfelvétel, stúdióban rögzített tartalom vagy kisfilm (hagyományos filmes technikákkal készített oktatási tartalom).

Minijáték Minjátéknak az olyan komplex interaktív, és elvárhatóan játékos elemeket, logikát is tartalmazó megoldásokat nevezem, amelyek túlmutatnak az egyszerű kattintás alapú tartalombemutatáson (lásd szöveges tartalom).

Tudásmérés Fontos tartalmi elem egyfelöl a visszacsatolás, másfelől a tanulási 3-5 perc útvonalak kialakítása kapcsán is a tanulók meglévő vagy megszerzett ismereteinek mérése, visszamérése. Legtöbbször elgondolkoztató vagy zárt, feleletválasztó kérdésekkel. Ez kombinálható adaptív megoldásokkal, ahol a korábban értékelt ismeretek alapján változhatnak a kérdések, és ezzel hatékonyabb visszajelzések nyújthatók a tanulók számára. (Weber és Vas, 2015) A tudásmérés további módozata az opcionális zárótesztek (vagy kvíz) is, amelyek a teljes anyag elsajátításával kapcsolatosan adhatnak visszajelzést, azonban sosem egyeznek meg a keretrendszerbe javasolt vizsgával, tanúsítást biztosító, komplex, időben is hosszabb tesztekkel. Mind a tanulást „megszakító”, kiegészítő tesztek, mind a zárófelmérések esetében azonnali visszajelzés adása elvárt.

Szimuláció A szimulációs tartalmak egyik ágát a szoftverszimulációk jelentik, 5-10 perc ${ }^{3}$ amelyek hatékony megoldások szoftverhasználat oktatásával kapcsolatosan, ahol szimulált környezetben ismerhetők meg funkciók, folyamatok. A másik ágat pedig az olyan inkább szemléletformáló, helyzetalapú, legtöbb esetben videós tartalommal készült objektumok, amelyek döntési helyzeteket szimulálnak. Ez utóbbi komplex megvalósítása esetén önálló tananyagként is definiálható.

Szakanyag Részben az eltérő tanulási szokások miatt (lásd nyomtatási nem lehetőség), részben pedig a „kötelező”, kisbetűs tudástartalmak értelmezhető okán elkerülhetetlen sok esetben letölthető szakanyagok implementálása is.

\footnotetext{
${ }^{3}$ Komplex megvalósítás, önálló tananyag esetén több óra is lehet.
} 


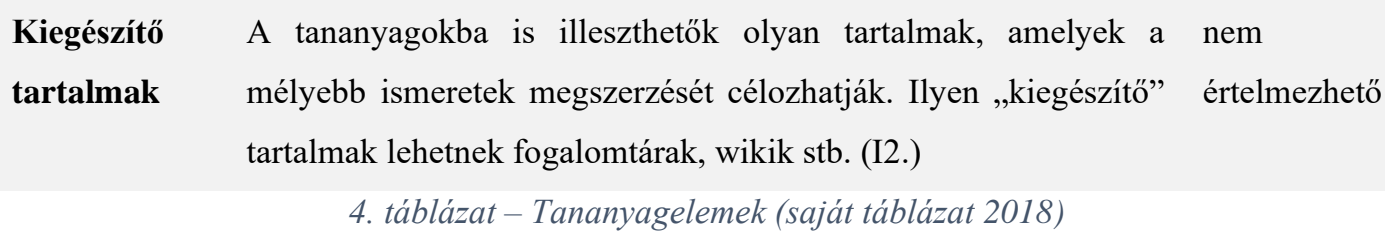

A fenti meghatározások során már fontos tényezőként kiemeltem a „megtekintési” időt. Saját megfogalmazás szerint ez az idő az, ami egyszeri elolvasást, megnézést, meghallgatást, „végig kattintást”, vagyis „klasszikus” tartalomfogyasztást jelent. Azonban ez nem egyezhet meg a „tanulási” idővel, amely már a kognitív képességek és a környezeti hatások által befolyásolt időtartam. (Részben már az olvasási idő is ilyen, de ezzel kapcsolatosan megfelelö átlagok meghatározhatók.)

\subsubsection{A „tanuló- és tartalomközpontú” e-learning tananyag meghatározása - amiért érdemes dolgozni}

Ebben a fejezetben áttekintem a szakirodalom által és saját megfigyeléseim által megfogalmazott elvárásokat, amelyek jellemzőit tekintve definiálja az egyszerre tanuló- és tartalomközpontúnak tekinthető e-learning tananyagot, amely később hivatkozási alap is lesz.

A tanulóközpontúság arra utal, hogy a termék esetében és a fejlesztés teljes folyamatában figyelembe szükséges venni, hogy a tananyagból végeredményképpen különböző alapképzettségü, szociális hátterü, személyiségü és képességü emberek tanulnak majd. A tanulóknak egyenként különböző a tanulási stílusuk, bemeneti kompetenciájuk, hangulatuk, és az is, hogy mennyi rendelkezésre álló idejük van van.

A tartalomközpontúság pedig összefoglalóan arra utal, hogy úgy pedagógiai mint elearning módszertani és szakmai tartalmat tekintve is kifogástalan termékek készüljenek, függetlenül attól, hogy mi a tanítás célja az ismeretek átadásától a szemléletformáláson keresztül vagy a készségek gyakoroltatásán át. Összefoglalva a „jó” e-learning tananyag az alábbi szempontoknak felel meg.

Tanulóközpontú
szempontok
Reflektál a különböző
tanulótípusokra,
tanulási stílusokra

Kifejtés

A különböző tanulótípusok különböző megjelenítési és módszertani megközelítéseket igényelnek (Bodnár, 2007). Ez támogatható az által, hogy pl. ugyanazt az LO-t több fajta módon tesszük elérhetővé (pl. a szövegek felolvasásával stb.) vagy a különböző stílusoknak megfelelö feladatokat dolgozunk ki, egyedi tanulási útvonalakat nyújtunk. 
Reflektál a különböző tanulási

körülményekre

Könnyen kezelhető, egyértelmű a navigáció

Megjelenítése, arculata
megfelel a
célcsoportnak és a
trendeknek

Megragadja és

fenntartja a tanuló

figyelmét

Kollaborációs

lehetőségeket nyújt
Az e-learning egyik „klasszikus” előnye, hogy bárhol és bármikor elérhető a tananyag. Ez sok olyan nem konvencionális tanulási helyzetet, körülményt jelenthet pl. tanulás egy tömegközlekedési eszközön utazva, nem pedig egy íróasztal mellett. De épp így ismérve lehet a tanulásra szánt idők eltérő volta: 10 perces sorba állás szemben a több órás elmélyült tanulással. Ezeket a helyzeteket egyfelöl a több stílusban előállított tartalmak, másfelől a tananyag moduláris felépítése támogathatja.

Mint más webes technológiákkal készülő digitális terméket, úgy, az elearning tananyag esetében is fontos, hogy használata intuitív legyen, a tanulónak ne azzal kelljen foglalkoznia, hogy a tananyag használatát tanulja (hacsak nem épp ez is cél), hanem a trendeknek megfelelö, átlátható, kezelhető felhasználói felületeken keresztül tanulhasson.

A vizuális megjelenítés számos szempont miatt kiemelkedően fontos: az első benyomás, a tanulási motiváció és a reflexió a tanulótípusokra is. A megjelenítés illeszkedjen a megszokott arculatokhoz (pl. vállalati stb.). A kutatásba bevont interjúalanyok mindegyike ezt az egyik legfontosabb szempontok között emelte ki.

Részben az előző vizuális megjelenítés ponthoz kapcsolódik, de a látványon kívül fontos része az a tényező, amellyel a tanulót be lehet vonni és bent lehet tartani a tanulási szituációba. Ez épp úgy lehet egy videós tartalom esetében egy látványos, meglepö felütés, vagy egy izgalmas kerettörténet, amely a tovább haladásra sarkallja a tanulót. További eszköz lehet, egy a történethez illeszkedő tanulótárs alkalmazása is. Kutatások bizonyították a multimédiás és interaktív tartalmak pozitív hatását (Zhang, 2005; Lee, 2010). Valamint itt említhetők meg a játékosítással összefüggő (gamification) törekvések is, amelyeknek ugyancsak ismertek a pozitív hatásai (Urh et al., 2015; Varannai et al., 2017).

A tanuló-tanuló és az tanár-tanuló együttmüködésre inkább a keretrendszerek nyújtanak eszközöket (pl. fórum stb.), de e kollaborációs lehetőségeket integrálhatjuk is az e-learning tananyagokba: akár technológiai oldalról (pl. beépített csevegési lehetőség), akár módszertani szempontok szerint (pl. együttmüködésre sarkalló feladatok által) (Balkányi és Orbán, 2012). 


\author{
Tartalomközpontú \\ szempontok
Reflektál a különböző
tudásszintü, készségü
tanulókra

A tartalom lektorált

E-learning by design

tartalom

Módszertani

szempontból megfelelő

Technológiai

szempontból megfelelő
Kifejtés

Az e-learning tananyagokat sokszor nagylétszámú képzések során alkalmazzák. Kutatások (Gilbert et al., 2007) is igazolták, hogy ezekben az esetekben igen ritka, hogy minden tanuló azonos szintről lépjen be a folyamatba és azonos tempóban haladjon. Ezt alapvetően a képzési program szintjén érdemes kezelni, de bizonyos mértékben lehetőség van a tananyagok szintjén is foglalkozni a kérdéssel, pl. a magasabb szinten lévők számára kitekintő ismeretek beépítésével, vagy az alacsonyabb ismeretekkel rendelkezőknek fogalomtárak kialakításával.

Mind szakmailag, mind nyelvhelyesség szempontjából lektorált tartalmakat érdemes gyártani. Talán nem is szükséges részletesen megmagyarázni ennek jelentőségét.

Szerencsés, de nem minden esetben elvárható, hogy már a forrásanyag készítése során is tisztában legyen azzal a szerző, hogy kifejezetten képernyő előtti tanuláshoz készít szakmai tartalmat. A fejlesztés további szakaszaiban pedig már elvárás is. Ezt jelenti a célcsoport számára megfelelő hosszúságú szövegek, videók stb. alkalmazása, illetve a hagyományos tananyagoktól eltérő - moduláris felépítése.

Minden esetben elvárás lenne a tartalom módszertani feldolgozása, hogy olyan pedagógia és e-learning technikai megoldásokat alkalmazzon a tananyag, amely egyfelől megfelel a célközönségnek, másfelől pedig megfelel a kitüzött tanítási célnak.

Ahhoz, hogy a megfelelö tartalom el is jusson a tanulókhoz, ahhoz érdemes szabványos, a célcsoportnak megfelelő eszközökre optimalizált tananyagokat fejleszteni. Érdemes a célcsoporttól is folyamatos visszajelzéseket gyüjtve tesztelni a terméket.

6. táblázat - A tartalomközpontú e-learning tananyag jellemzői (saját táblázat 2019)

A tanuló- és tartalomközpontú e-learning tananyag 5. táblázat és 6. táblázatokban összefoglalt jellemzőiből az alábbi szempontokat érdemes szem előtt tartani a fejlesztések során:

A tananyag tartalom szempontból:

- vegyesen alkalmazzon lektorált tartalomtípusokat,

- módszertani és technológiai szempontból legyen kifogástalan.

A tananyag kialakítási szempontból:

- legyen moduláris felépítésű és képernyő előtti tanulásra tervezett, 
- alkalmazzon könnyen kezelhető és intuitív felületeket,

- legyen látványos (pl. multimédiás tartalmak) és interaktív.

A tanulási folyamat szempontjából:

- tartalmazzon egyedi tanulási útvonalakat,

- tartalmazzon kerettörténetet és/vagy tanulótársat és erős indítást.

\subsubsection{A tananyagok értékelési rendszere - szintek és keretek az értékelésekhez}

A digitális tananyagok nem értelmezhetők a képzési környezet, azok rendszere nélkül. Ennek megfelelően az tananyagértékelés is egy nagyobb képzésértékelés egy szelete. A felsőoktatási minőség-ellenőrzése általában regionális, nemzeti ajánlásokra vagy tudományterülethez kapcsolódó akkreditációs szervezetekhez kapcsolódik (pl. AACSB). Vállalati környezetben a tréningek értékelése során megkerülhetetlen a Kirkpatrick (1977) féle négy szintü értékelési rendszer, amelyben a „legegyszerübb” a reakciók értékelése (pl. kurzust követő kérdőív, résztvevői szint), ezt követi a tanulás értékelése (pl. vizsga, tanulási környezet szintje), majd a magatartás(változás) értékelése (pl. 3 hónapos utókövetés, a munkakörnyezet szintje), végül a legkomplexebb elem az eredmények értékelése (pl. 6 hónappal később a menedzsment bevonásával, szervezeti szint). Ehhez kapcsolódik Philips ötödik szintje, amely a megtérülést (ROI) is az értékelés részévé emeli, amely „e-learning szempontból” mindig kulcskérdésnek tekinthető. E megközelítés azért is fontos, mert a képzéseknek egy olyan helyet adhat a nagyvállalati környezetben, amely valóban összekapcsolja a tréningeket az üzleti elvárásokkal és mérhető eredményekkel (Galloway, 2005).

Közelítve a távoktatási megoldások értékelési rendszerekhez, a szakirodalom alapján a legfontosabb értékelési területnek a szervezet elkötelezettségét, támogatását és vezetést tekinthetjük. Ezeket követi a tanítás és tanulás értékelésének területe, a hallgatói elégedettség vizsgálata kevésbé jellemző (Shelton, 2011). Említésre méltó még Shelton (2010) 70 elemü minőségi mutatószámrendszere, amely 9 területen belül, 210 pontos skálán értékeli a felsőoktatási távoktatási képzési programokat. A képzési és távoktatási rendszer értékelése mellett a technológiai szempontok a Technológia Elfogadás Modellje (Technology Acceptance Modell - TAM) alapján értékelhetők a felhasználói attitüdök. „A TAM és a hozzá hasonló, a technológiával szemben tanúsított attitüdök mérését támogató modellek (Theory of Planned Behavior - TPB, Unified Theory of Acceptance és Usage of Technology - UTAUT) olyan indikátorokat 
dolgoztak ki, mint a felhasználó által észlelt hasznosság, a használhatóság, a játékosság, a számítógépes énhatékonyság, a szociális és környezeti hatások, valamint a felhasználót segítő, támogató feltételek repertoárja.” (Csedő et al., 2014, p.11). Kifejezetten a tanulói perspektívát vizsgálta Jung (2011), az ő kutatása alapján, és a digitális tananyagok szintjéhez érve Busstra (2007) és Diederen (2003) cikkeire támaszkodva is elmondható, hogy az alábbiak az értékelések legfontosabb szempontjai: (1.) a tanulási célok teljesítése; (2.) a hallgatók motivációjának kialakítása és fenntartása; (3.) az aktív tanulás és a tanuló támogatása; (4.) a tananyagok olyan vizuális megjelenítése, amely ösztönzi és támogatja az előbbieket. Ahogy egyik interjúalanyom fogalmazott: „Fúr, farag, csicsereg.” (I7.), de ezt a szempontot szinte kivétel nélkül fontosnak tartotta minden szakértő; (5.) a szervezet támogatása és részvétele.

Jelen disszertációnak nem célja egy komplex értékelési keretrendszer kialakítása a fenti szempontok figyelembevételével, de nem elhagyható szempont a minőségbiztosítás. Az e-learning tananyagok fejlesztésének komplex folyamatában épp ezért fontosnak tartom, hogy egy kialakított értékelési rendszer mentén, mérhető fejlesztések valósuljanak meg, lehetőség szerint a fentiekben vázolt $4+1$ szinten (reakció, tanulás, változás, eredmény, ROI). A kutatásba bevont projektek (lásd 3.1 fejezet) adatlapjain jelzem, hogy az egyes projektek esetében milyen értékelési elemek valósultak meg.

\subsection{Az e-learning társterületek azonosítása és elemzése - az érintett területek felkutatása és áttekintése}

A DS szigorú kutatási elveinek megfelelően mind a problémafelvetés, mind a megoldás konstruálása kapcsán széleskörü háttérismeretekre, a kurrens irodalom feldolgozására is szükség van. Az e-learning tananyag fejlesztési folyamata sem értelmezhető a kapcsolódó tudományos környezet és az érintett területek vizsgálata nélkül. A folytatásban szisztematikusan ismertetem a kapcsolódó területeket, amely alapja lehet az tananyagfejlesztési ökoszisztéma felvázolásának.

\subsubsection{Az e-learning társterületeinek azonosítása - a feltárás szövegelemzéses vizsgálata}

Számos olyan terület azonosítható, amelyek ismeretei és eredményei szervesen illeszkednek az e-learning tananyagfejlesztés folyamatába. Ezek nélkül az ismeretek 
nélkül hiányt szenvedne a fejlesztés. A fentiekben összefoglalt területek mélységi elemzése és ismertetése túlmutat jelen disszertáció keretein, de mégis fontosnak tartom e területek kapcsolódását röviden áttekinteni. A kapcsolódó területeket nem csak saját szakmai tapasztalatomra alapozva kívántam bevonni a disszertációba, hanem egy szövegelemzési eljárással elemzem, hogy mely területek vizsgálata releváns. Ezzel választ adok az első kutatási kérdésre (KK1). E területeket az alábbi, 7. ábrán olvasható kulcsszavak elemzésére alapuló módszertan segítségével azonosítottam (Nemeslaki, 2018).

\begin{tabular}{|c|c|c|c|}
\hline \multicolumn{5}{|c|}{ Kulcsszavak keresése } \\
\hline e-learning & content & development \\
\hline \multicolumn{5}{|c|}{ Corpus kialakítása } \\
\hline Google Scholar & Microsoft Academic & Crossref \\
\hline \multicolumn{5}{|c|}{ Scopus } \\
\hline egyezésvizsgálat & kollokáció gyüjtés & kategórizáció \\
\hline 7. ábra - Társteriuletek felkutatása, módszertani összefoglaló (saját ábra 2019)
\end{tabular}

Hartzing Publish or Perish ${ }^{4}(\mathrm{PoP})$ alkalmazása segítségével rákerestem a Google Scholar, a Microsoft Academic, Scopus és a Crossref keresőben 2014-2018 közötti időszak összes olyan publikációjára, amely kapcsolatos lehet jelen disszertációval (minden szó: „e-learning” és bármely szó a következők közül: „content”, „material”, „curriculum”, „content development”, „material development”).

Az eredményeket exportáltam, majd kiszürtem az egyező tartalmakat. Ezt követően corpust alakítottam ki az összesen 1407 darab publikáció címéből.

Majd a Laurence Anthony által fejlesztett AntConc ${ }^{5}$ elnevezésü, ingyenes corpus analízishez, egyezésvizsgálathoz és szövegelemzéshez használható alkalmazás segítségével kigyüjtöttem a leggyakrabban előforduló szavakat szókapcsolati (kollokáció) vizsgálat alapján. A vizsgálat során legalább 7 szókapcsolati gyakoriságot

\footnotetext{
${ }^{4}$ https://harzing.com/resources/publish-or-perish/

${ }^{5}$ http://www.laurenceanthony.net/software/antconc/
} 
vizsgáltam az „elearning” szó esetében, 5-5 szó távolságra jobbra és balra. Az eredménye 75 típus, azonban ezeket szükséges volt még megszürni (pl. „of” vagy „research” szavak), ezek alapján 44 érdemi szó maradt a listában, amelyeket az alábbi kategóriákba soroltam. (Az AntConc eredménytáblázata a mellékletben, a 6.1 fejezetben található.)

\begin{tabular}{|c|c|}
\hline Kategória & Elemszám \\
\hline Módszertan & 17 \\
\hline Technológia & 15 \\
\hline Szakmai & 5 \\
\hline Szervezet/környezet & 4 \\
\hline Tudásmenedzsment & 3 \\
\hline
\end{tabular}

7. táblázat - Publikációs kategóriák szókapcsolati elemzés alapján (saját kutatás 2018)

Az AntConc kollokációs elemzése mellett a fent ismertetett corpuson - az ugyancsak publikus, és hazai kutatásokban is alkalmazott (Nemeslaki, 2018; Demeter et al., 2018; Gajdács, 2019) - VOSViewer ${ }^{6}$ nevü vizualizációs szoftver segítségével is vizsgálatot folytattam. A VOSViewer a hasonlóságokat vizualizálja (VOS), a térképet az együttes előfordulási mátrix alapján számolja. A térkép kialakításhoz az alábbi három lépést teszi meg a program:

1. Hasonlósági mátrix kiszámítása: az előfordulási mátrix normalizálásából kerül kiszámításra, az előfordulások és az együttes előfordulások teljes számának különbségéből. A normalizáláshoz az „asszociációs erősség” hasonlósági mérést alkalmazza a program. A hasonlóság $\left(\mathrm{s}_{\mathrm{ij}}\right)$ számítását mutatja be a 8. ábra két elem (i és j) között, ahol c $c_{i j}$ az együttes megjelenés, $W_{i}$ és $w_{j}$ pedig i és j összes száma vagy összes együttes száma.

$$
s_{i j}=\frac{c_{i j}}{w_{i} w_{j}}
$$

\section{8. ábra - Hasonlósági kiszámitása (van Eck és Waltman, 2010)}

2. Térkép kialakítása: a program egy kétdimenziós térképet készít az előző pontban kiszámítottak alapján. A nagyobb hasonlósági számmal rendelkezők közelebb kerülnek egymáshoz, míg a kisebb számok távolabb. „A VOS leképezési technikája minimalizálja az összes elempár közötti négyzet alakú

\footnotetext{
${ }^{6}$ http://www.vosviewer.com/
} 
euklideszi távolságok súlyozott összegét.” (van Eck és Waltman, 2010, p.531).

3. Fordítás, forgatás, reflexió: mivel az előző lépés eredményei nem jelentenek egyedi globális megoldást, ezért az alkalmazás az eredményt transzformálja három szempont szerint: a középpontba helyezi, fökomponens elemzés alapján elforgatja és a medián értékek alapján tükrözi (van Eck és Waltman, 2010).

A VOSViewer vizsgálathoz szükséges volt az adatbázist átalakítani importálható formátumra (RIS), majd ezt követően megfelelő módon paraméterezni. A VOSViewer 3073 kifejezést azonosított, majd a küszöbérték (itt is legalább 7 megjelenés) beállítását követően kiszürtem az irreleváns kulcsszavakat. Az eszköz ezek alapján nyolc klasztert azonosított, és az alábbi ábrát rajzolta fel a szavak összefüggései alapján.

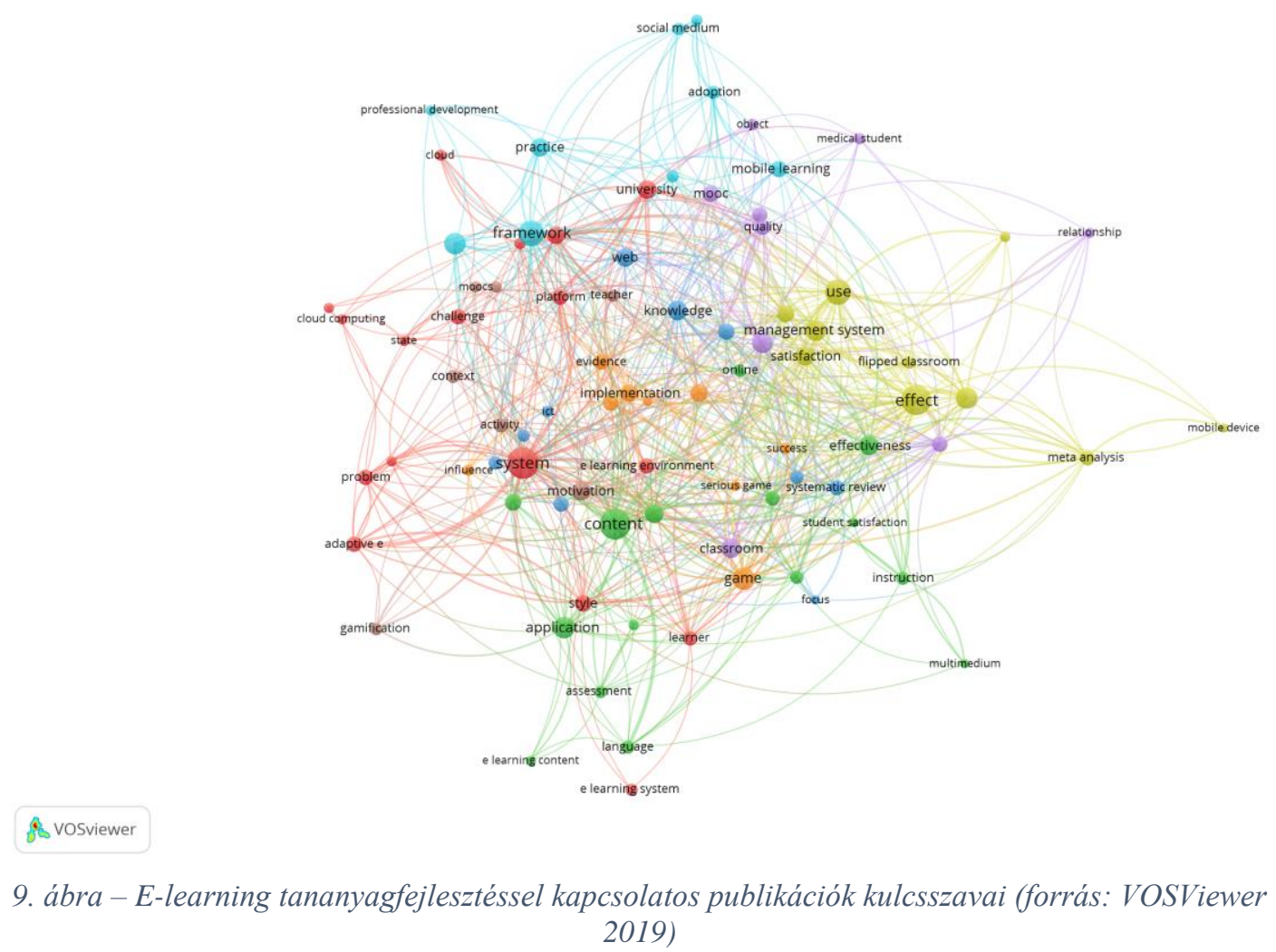

A két vizsgálat eredménye alapján az alábbi kategóriákat azonosítottam: módszertani témák, szervezetre vagy környezetre vonatkozó publikációk, technológiai kérdések 
vizsgálata. Érdekesség, hogy a szakmai területek közül az egészségügy kiemelkedő számossággal szerepelt a publikációkban.

A szakirodalmat áttekintve számos publikációt találhatunk, amelyek górcső alá helyezték az e-learning kutatási területeit, és a releváns témákat keresték. Az irodalmi irányok pl. szakértői véleményekre alapoznak (Zawacki-Richter, 2009), vagy bibliometrikus kutatásra épülnek pl. a SCOPUS adatbázisában (Tibaná-Herrera et al., 2018). Vannak közlemények az e-learning kutatás taxonómiáját megalkotva (Adkins et al., 2017), szövegelemzést végezve (Hung, 2012). A felsoroltak mind-mind hozzátesznek a terület pontosabb értelmezéséhez. Az e-learning területén népszerü kutatási témákról évről-évre átfogó és szisztematikus elemzést készít a katalóniai Oberta Egyetem (Molas-Castells és Fuertes-Alpiste, 2018), amely alapján a legnépszerübb kutatási kategóriák:

- a tanulási erőforrások tervezése, fejlesztése és értékelése,

- innovatív pedagógia technikák, eszközök,

- tanulás elemzése és automatizálása.

Jelen disszertáció az első kategóriába sorolható, az e-learning és multimédiás tananyagok fejlesztése az erőforrások része. Emellett egyéb általam „technológiainak” nevezett témák tartoznak ide:

- e-learning eszközök, platformok,

- kurzusfejlesztés,

- multimédia (pl. videó), közösségi média, MOOC-ok, digitális könyvtárak.

Az innovatív pedagógia technikák között a tanulmány (az első helyen szereplő) mobil tanulás mellett a tükrözött osztálytermet, a játékosítást, a virtuális- és kiterjesztett valóság és a történetmesélést említi. Ezeket a folytatásban „módszertani” területként hivatkozom.

Míg az elemzés, automatizálás területén a big data, az adatvizualizáció, az adaptív tanulás és tanitást, az ajánlórendszerek és intelligens tutorok, az érzelmek és gesztusok felismerése szerepelnek, melyekre „tanuláselemzésként” tekintek a továbbiakban. A fentiek mellett a szerzők még számos egyedi kategóriát elkülönítettek, amelyek egy részét én a saját elemzés alapján a „szervezet, környezet” átfogó témakörbe soroltam, ilyenek: a hallgatók a pszichológiai változói, a hallgatói teljesítmény, a tanári szerep 
vagy a „módszertani” kategóriába értelmezem: a kollaboráció, az értékelés, az tanítás tervezés (instructional design) (Molas-Castells és Fuertes-Alpiste, 2018). Greg Blackburn (2016) publikációjában, miközben az e-learningről szőtt nagy álmok, és a valóság közötti eltérést elemezte, az e-learning terület mozgatórugóit mutatta be, amelyek az ő megközelítése szerint három kategóriába sorolhatók: fentről-lefelé haladó (pl. jogi környezet, pénzügyek, kormányzás stb.), lentröl-felfelé haladó (pl. tartalmak, tudás, kutatás, visszajelzés, kurzusfejlesztés stb.) és kereskedelemi (nyereségorientált, pl. verseny, gazdaság, vásárlók stb.), amelyek mindegyikére vonatkoznak az „univerzális e-learning hatások”: pedagógia, technológia, politika, földrajzi elhelyezkedés, kultúra. Ez a szerző helyezi el az elemzés során az egész rendszert olyan tudásmenedzsment megközelítésbe, amely megfigyelésem szerint is fontos: „A tudásmenedzsment (KM) magában foglalja egy szervezet tudásának széles értelemben vett azonosítását, megőrzését, fejlesztését és hasznosítását, mintha csak adatbázis kezelésről lenne szó. Egy szervezet átlagos munkanapján, minden szinten, [...] minden alkalmazott kihívásokkal találkozik és old meg, és ezáltal pragmatikus ismereteket szerez. Ez a tudás kinyerhető és szelektálhatók azok az elemek, amelyek a szervezet egésze számára fontosak, és társadalmi tőkéként a jövedelmezőséghez kapcsolható.” (Blackburn, 2016, p.93)

A fentiek tükrében a folytatásban a disszertáció későbbi fejezeteihez és az e-learning tananyagfejlesztés ökoszisztémájának kialakításához értelmezési keretet nyújtva, az alábbi területeket fejtem ki bővebben:

a) projekt- és szoftverfejlesztésmenedzsment,

b) tananyagfejlesztési pedagógiai és technológiai módszerei,

c) tudásmenedzsment és szervezeti innováció.

\subsubsection{Kitekintés a társterületekre - a tágabb tudományos környezet összefoglalása}

Általában egy e-learning tananyagfejlesztés projekt jellegű feladat. Kifejezetten ritkák azok a megbízások, munkák, ahol nem egy-egy projekt valósul meg, hanem az elearning tananyagfejlesztés új folyamatként beépül a szervezetbe. Ennek megfelelően az egész folyamaton átívelő szempont a projekt-szerü technológiai megvalósítási kérdések, amelyeket a webes technikák és a szoftverfejlesztés ismeretei, a megfelelő projektmenedzsment biztosításhat. Ezek közül is az IT területén megvalósuló 
szemléletek és technikák dominálnak, hiszen a végtermék digitális termék. A projektek mibenlétével, kérdéseivel és kihívásaival a szakirodalom pl. Schwalbe (2015) igen részletesen foglalkozik. Napjaink modern szemléletei (pl. agilitás, scrum stb.) pedig azért is érdekesek, mert számos olyan technikát, szemléletet foglal össze, amelyek közül egy adott e-learning tananyagfejlesztés esetében érdemes lehet megvizsgálni a leginkább releváns metódust (Abrahamsson et al., 2002; Schwaber, 2004; Despa, 2014). Az e-learning világban elfogadott, bár valójában idejét múlt szabvány a $\mathrm{SCORM}^{7}$, amely valójában az amerikai Advanced Distributed Learning (ADL) kezdeményezése. A SCORM szabványos keretként szolgál a tananyagokba betölthető szöveges, interaktív és multimédiás tartalom tekintetében. A szabvány alkalmazása két gyakorlati szempont miatt lényeges: (1.) a kompatibilitás és (2.) a kommunikáció. Míg az előző a különböző szerkesztő-eszközök és rendszerek közötti átjárhatóságot kívánja szolgálni, addig az utóbbi a tananyag és a rendszerek közötti kapcsolatra vonatkozik. Ez a kapcsolat az alapja az előrehaladás monitorozásának és a pontszámok átadásának. A klasszikus webes technológiák irányából még az Adobe által fejlesztett, de időközben folyamatosan kivezetésre kerülö, Flash szabvány méltó még említésre, hiszen a HTML5 szabvány ${ }^{8}$ elterjedéséig a tananyagokba kerülő interaktív és multimédiás tartalmak legtöbb esetben e technológia szabványa szerint készültek. A modern böngészők és a mobil eszközök robbanásszerü elterjedése pedig kikényszerítette az új HTML és CSS szabványok alkalmazását, amelyek így alap nyelvei a tananyagok fejlesztésének is. Kitekintésként megemlíthető a mobil alkalmazások fejlesztése, mint e-learning megoldás (Balkányi, 2015), bár ennek helyettesítésére az ún. reszponzív megoldások nyújtanak alternatívát. A gyakorlati, gyártási szinten az e-learning tananyag is egy szoftver, és ennek megfelelően a szoftverfejlesztésekre jellemző módszertanok müködhetnek ebben a fázisban. A disszertáció fókuszát ebben a témában sem kívánom elfordítani a tananyagfejlesztés irányából. Ezen a területen is a leginkább elterjedt a klasszikus „vízesés” metódus és a „V-modell” alkalmazása, ami jól illeszkedik egy lineáris tananyagfejlesztési folyamathoz is, de egyre elterjedtebbek (részben a trendeknek való megfelelés miatt) a sprint alapú, agilis megoldások is. Ezek közül a tananyagfejlesztés szemszögéböl a

\footnotetext{
${ }^{7}$ https://www.adlnet.gov/scorm/

${ }^{8}$ https://www.w3.org/TR/html5/
} 
„prototípus készítés”, „iteratív és inkrementális” (I\&I) és a „scrum” modellek jól alkalmazható megközelítéseket adhatnak, de mellettük is számos más metódus ismert (Despa, 2014).

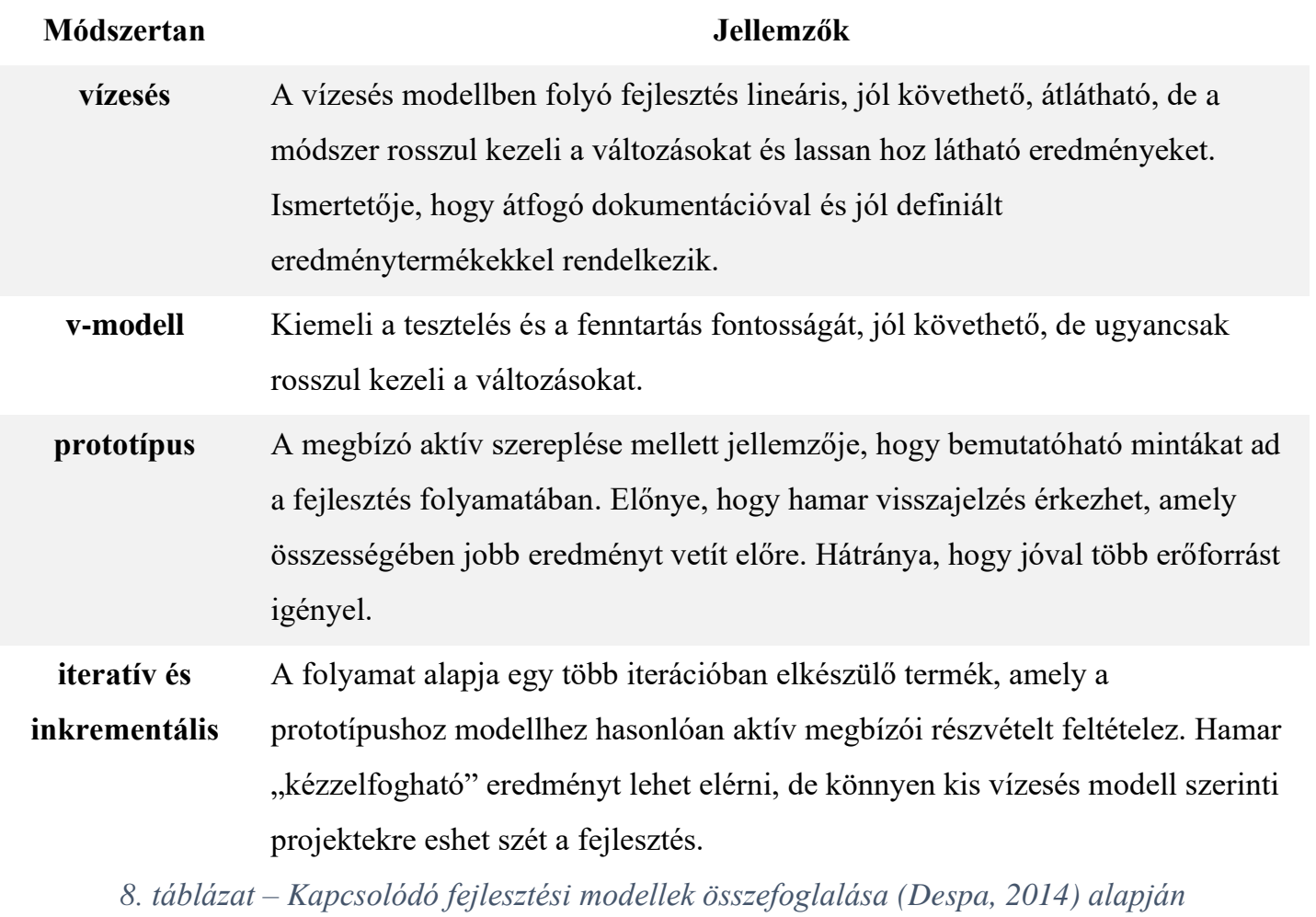

A megfelelő technológia és projektmenedzsment szemlélet tehát megfigyelésem szerint csak egy-egy szempont a sok közül, amelyet egy e-learning tananyagfejlesztés során mérlegelni szükséges. Hasonló kérdéskör a „megfelelő” módszertanok kiválasztása és alkalmazása. Ez egyik oldalról szükségét jelenti az alapvető tanulási elméletek ismeretének: behaviorizmus, kognitivizmus, konstruktivizmus. Másfelől pedig e teóriák különböző kombinációi és felhasználási módjai meg is határozzák azokat a konkrét tananyagfejlesztési kereteket, amelyek mint „oktatás tervezési” (instructional design - ID) kérdések jelennek meg (Alonso et al., 2005). Az elméletek mind saját szemszögükből a különböző ismeretek, készségek megtanulásának és a tanulási élmény kialakításának megértését tüzik ki célként. Ebbe, tágan értelmezve, beletartozik a megfelelő tudáselemek, tanulási aktivitások kiválasztása, a tanulók tudáselsajátításának támogatása, az előrehaladás ellenőrzésének és a visszajelzési rendszernek a pedagógiai, módszertani kialakítása is (Merrill et al., 1996). E kérdéskör kutatása sok évtizedes múltra tekint vissza. Hatása, kapcsolódása a digitális technológiákhoz ugyancsak egy folyamatosan vizsgált terület. Lásd instructional design és technology - IDT (Reiser és Dempsey, 2012). Az ID modellek közül 
mindenképp kiemelendő az ADDIE (Analysis, Design, Development, Implementation, Evaluation), amely az előző évszázad hetvenes éviből datálódik, de a mai napig alapvetése a tanulástervezésnek (Kurt, 2017). Az ADDIE mellett még számos módszertani megközelítés nyert teret, a teljesség igénye nélkül: Merrill's Principles of Instruction (MPI), Gagne's Nine Events of Instruction, Bloom's Taxonomy, Successive Approximation Model (SAM), CCAF (Context, Challenge, Activity, Feedback) (Khalil és Elkhider, 2016; Allen, 2016).

Saját kutatásként a Google Trends eszközzel megvizsgáltam, hogy mely keresési kifejezések voltak népszerüek egy bizonyos időszakban.

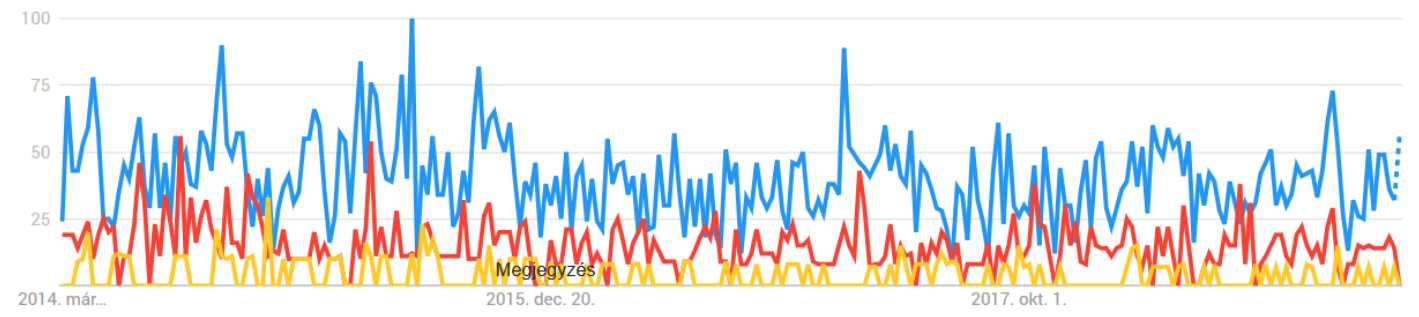

10. ábra-Keresökifejezések összehasonlitása (Google Trends, 2019)

A fenti modelleket vizsgálva, egyértelmüen az ADDIE modell, Bloom taxonómiája és a SAM modell tart számot a legnagyobb érdeklődésre. A 10-es ábrán a fenti (kék) vonal a legtöbbet keresett kifejezést mutatja, amely az „ADDIE model”. A második (piros) a „Bloom’s Taxonomy”, míg a legalsó (sárga) vonal a „Successive Approximation Model” kifejezést jelöli. A beállításokat ${ }^{9}$ tekintve az elmúlt 5 év keresési eredményei láthatók, az Egyesült Államokra szükítve, minden keresési kategóriát választva. Érdekesség, hogy ha „csak” a tudományos területre szükítjük a kereséseket ${ }^{10}$, akkor Bloom elmélete számít a legkeresettebbnek. A fenti modellek mellett - a teljesség igénye nélkül - további fontos tanulságok vonhatók le a tananyagfejlesztést tekintve az alábbi hazai kutatásokból is. A kutatásokban megjelent ismeretek az alábbiak:

\footnotetext{
${ }^{9}$ https://trends.google.hu/trends/explore?date=today\%205-

y\&geo=US\&q=\%22ADDIE $\% 20$ Model $\% 22, \% 22$ Bloom $\%$ E2\%80\%99s $\% 20$ Taxonomy $\% 22, \% 22$ Successive $\% 20 \mathrm{~A}$ pproximation $\% 20$ Model $\% 22$

${ }^{10} \mathrm{https}: / /$ trends.google.hu/trends/explore?cat=174\&date=today\%205-

y\&geo=US\&q=\%22ADDIE\%20Model $\% 22, \% 22$ Bloom $\%$ E2\%80\%99s\%20Taxonomy $\% 22, \% 22$ Successive $\% 20 \mathrm{~A}$ pproximation $\% 20$ Model $\% 22$
} 
- az online tartalmak fejlesztése a különböző tanulótípusok elemzése (Bodnár, 2007),

- az e-learning tananyag felhasználók mentális és érzelmi állapotát vizsgáló kutatások (Hercegfi et al., 2009),

- a sikertényezők elemzése (Veress, 2008),

- az online kurzuskészítés (Szimkovics, 2016),

- az általános felsőoktatási összefoglalások (Harangi és Kelner, 2003).

A magyar tudományos müvek szinte kivétel nélkül vagy felsőoktatási vagy közigazgatási fókuszúak. Piaci tapasztalatokra alapozó elemzést a Google Scholar keresőben nem találtam magyar nyelven, 2010-et követő időszakról. E tekintetben is a jelen disszertáció pótolni kívánja e hiányt.

Egy komplex e-learning tananyagfejlesztés estében nélkülözhetetlennek gondolom a különböző tudásmenedzsment (knowledge management $-\mathrm{KM}$ ) ismeretekkel kapcsolatos elméletek beépítését, figyelembevételét. Többek között azért is, mert a KM adhatja a forrását, az alapinformációit a tanulásnak és így az e-learning tananyagoknak is. A KM szakirodalom is erre a következtetésre jut. Wild és munkatársai (2002) rámutatnak, hogy az e-learning abban segíthet, hogy a sokat változó szervezetekben állandó, mindig elérhető felületet ad a tudás megszerzésének és elosztásának. „Az e-learning előnyei kiegészítik és megerősítik a KM tevékenységeket.” (Wild et al., 2002, p.378) Továbbá King (2009) alapján, a KM egyik céljaként is megfogalmazható a szervezti tanulás (organizational learning - OL) (Aly, 2017), amelyek erősítik és támogatják egymást, valamint pozitívan hatnak a szervezeti hatékonyságra is (Liao és Wu, 2009). Egyes szerzők szinte egyenlőségjelet is tesznek a KM és OL közé (Firestone és McElroy, 2004). A szervezeti tanulás iskoláinak elemzése alapján Dierkes és kollégái (2003) az alábbiakra jutottak:

1. A tanulás a gyakorlatban dolgozók részvételen alapul.

2. Mivel a különböző tevékenységek kusza rendszereként lehet a szervezetekre tekinteni, ezért ezeken belül e tevékenységek mutatják meg a tudást.

3. A szervezti tudás a társas-materiális kapcsolatokban található.

4. A ,tudás elfogadott; megtalálható; rugalmas, ideiglenes; nyilvános és meghatározott” (Dierkes et al., 2003, p.51).

5. A nem emberi és emberi tényezők a gyakorlat során, idölegesen egymáshoz igazodnak a kapcsolatok hálózatában. 
Amikor az OL-re, mint dinamikus folyamat gondolunk, akkor figyelembe kell venni, hogy konfliktusokat is generál a tanulási folyamat az egyének és csoportok között, valamint a már meglévő tudás folyamatos felhasználása és az új ismeretek megjelenése között. Két dimenzió mentén jelenik meg a tanulás. Az egyik dimenzió mentén elöre mutat a folyamat az egyénektől, a csoportokon át jutunk el a szervezeti szintre, míg a másik dimenzió mentén „fentről lefelé” halad a tudás: a szervezeti szintről jut el az egyénhez. Mindkét esetben négy egymással folyamatos interakcióban lévő szakaszt azonosíthatunk: megérzés, megértés, beillesztés, intézményesítés. A szervezeti tanulást e két ellentétes irányú, dinamikusan változó környezet alakítja (Crossan et al., 1999). Hámornik és Juhász (2010) összefoglalása alapján a KM folyamat során a tudástőke:

- „kibontakozik, termelődik, részletezésre, megőrzése, megosztásra és integrálásra kerül”" (Hámornik és Juhász, 2010, p.105)

- az információk gyüjtése, a szervezet átalakítása, a feladatmegosztás kialakítása a képzések köré szerveződik.

A szakirodalom rámutat arra is, hogy a tudásmenedzsment és az e-learning értéklánca több ponton is fedésben van egymással. Az előbbi a KM igények meghatározásával kezdődik (KM1), majd a tudáshiányok meghatározásával folytatódik (KM2), és a hiányosságok megszüntetését (KM3) követően, a megszerzett tudás terjesztésével és alkalmazásával (KM4) zárul. Az utóbbi a szervezet felmérésével, felkészültségének vizsgálatával és megteremtésével (EL1) indul, a megfelelő tartalom tervezésével (EL2) folytatódik, majd ennek megfelelő bemutatásával (EL3) és az e-learning bevezetésével (EL4) zárul. Vegyük észre, hogy az EL1 immanens része a KM1 és KM2, míg a KM3 és KM4 pedig az e-learning értéklánc további három eleméhez kapcsolódik (Griggs et al., 2002). Egy szervezet felkészültsége az e-learning bevezetésére feltételez számos KM területével kapcsolatos elem meglétét is pl. rendelkezik-e a szervezet KM megoldással, gyüjtik-e az ismereteket valamilyen formában stb. Itt említendők ennél „,puhább” tényezőket is, mint pl. a munkatársak hozzáállása a tudásátadással kapcsolatosan, vagy éppen az informatikai felkészültségük. Jól látható az is, hogy pl. egy ontológia által támogatott KM megoldás segíthet a hiányzó tudásterületek meghatározásában, de akár a meglévő kompetenciák, ismeretek felmérésében is. Az illeszkedő szakterületi ontológiai kialakítására szükség van a megfelelő tudástartalom kiválasztásához és további IT fejlesztések alapja is 
lehet, a tudás megosztásával, átadásával (Kö, 2004; Vas, 2007). A tudásmenedzsment körfolyamatként értelmezése (Probst et al., 2006) mellet a szakirodalom számos életciklus megközelítést is ismer (Wiig, 1993; Bukowitz és Williams, 1999; McElroy, 2002; Kayani és Zia, 2012), az egyik ezeket komplexen összegző megközelítés Evans és Ali (2013) Tudásmenedzsment Ciklusa (Knowledge Management Cycle - KMC).

Az EL3 és részben az EL4 lépések koncentrálnak a tudás reprezentációjára és az elearning megoldások bevezetésének körülményeire, amelyek esetében fontos a hiányzó tudás „feltöltése” (KM3) és terjesztése (KM4). Az értékláncon túl a felmerülő problémák, kihívások kapcsán is kéz a kézben jár az e-learning és a $K M$ területe, hiszen mindkettő informatikai fejlesztést feltételez, szemléletmódváltást, stratégiai gondolkodást és legtöbbször jelentős befektetés. „Világos, hogy az e-learning előnyei kiegészítik és megerősítik a tudásmenedzsment folyamatokat [...]" (Griggs et al., 2002, p.378).

A tudás előállításával és felhasználásával kapcsolatosan érdemes kitérni a SECI modell ismeretére, amely a tacit és explicit tudás egymásra hatásaként írja le a tudás megjelenését, és egy spirális folyamatként értelmezi 4 fázis alapán: (1.) „Szocializáció” (Socialization), amelyet a tacit tudás megosztása jellemez a munkatársak társas érintkezései alapján, amelyből mások számára is tacit tudás alakul ki. (2.) „Externalizáfció” (Externalization), amely a tacit tudás kifejezését jelenti, amely a megértést támogatja, és explicit tudást jelent már a másik félnél. (3.) „Kombináció” (Combination), amely során az explicit tudás formálódik, rendszerré áll össze és komplex explicit tudás lesz belöle. (4.) „Internalizáció” (Internalization), amely esetében az explicit tudás gyakorlati felhasználása újabb tacit tudást eredményez (Nonaka és Toyama, 2003; King, 2009). E körkörös „tudáselőállítás” pedig az innováció lehetőségét hordozza, és a vállalat által nyújtott hozzáadott érték előállításához nélkülözhetetlen folyamatként határozható meg (Hámornik és Juhász, 2010). A szervezeti innováció azt jelenti, hogy a szervezet a külső és belső változások hatására új szokásokat és elképzeléseket épít be a müködésébe (Lam, 2004). Az előzőekben már bemutatott tudásgyarapítás (Nonaka et al., 1995) meghatározható, mint innovációs tevékenység. Egy szervezet tanulási orientációja pedig szorosan kapcsolódik innovatív képességéhez (Lee és Tsai, 2005). A szervezeti tanulás és a szervezti innováció pedig együttesen nyújtják a szervezet teljesítményének és versenyképességének növelését szervezeti mérettől függetlenül (García-Morales et al., 
2006). Ugyanis amikor a tudás elérhetővé válik és kifejezhető, akkor a minőség és a hatékonyság növelhető a képzések által (Dierkes et al., 2003). A szervezti innováció kognitív megközelítése szerint is lényeges tényező a tanulás, amelyeket az irodalom, igen szerte-ágazóan, a tanuló szervezetek kifejezéssel hoz összefüggésben. Anders Örtenblad (2013) nyomán Csizmadia (2015) négy szempontot ismertet a tanuló szervezetekkel kapcsolatosan:

1. szervezeti tanulás: kollektív cselekvés, potenciálisan hasznos változást eredményez, amely esetében a szemlélet az, hogy a tanulásnak csak pozitív eredményei lehetnek.

2. munkahelyi tanulás: egyéni, „on-the-job” tanulás, amely a kompetenciák fejlesztését jelentheti és a legújabb nézőpontok Engeström (2004) szerint ,_[...] a tanulók, a tanulási folyamat és a környezet folyamatos kölcsönhatása révén konstruál új tudásokat [...]" (Csizmadia, 2015).

3. tanulási környezet: tanulást ösztönző szervezti kultúra.

4. a tanulást támogató munkaszervezeti megoldások: Lam (2000) nyomán négy féle szervezti modell kapcsolódik a tanuláshoz: (1.) „szakértői bürokrácia”, (2.) „adhokrácia”, (3.) „J-szervezet” (Jellemzően japán vállalatok.), (4.) „gépi/ipari bürokrácia”. Míg az első kettőben a szabványos munkafeladatok szintje magas, addig utóbbiakban alacsony. A tudás hordozója a „szakértői bürokráciában” és az „,adhokráciában” az egyén, míg a „gépi/ipari bürokráciában” és a „Jszervezetekben” maga a szervezet (Csizmadia, 2015).

\begin{tabular}{|c|c|c|c|c|}
\hline $\begin{array}{l}\text { Szervezet } \\
\text { modell }\end{array}$ & $\begin{array}{l}\text { Innováció } \\
\text { és tanulás }\end{array}$ & Tudás & Jellemző & $\begin{array}{l}\text { E-learning } \\
\text { kapcsolódás }\end{array}$ \\
\hline $\begin{array}{l}\text { szakértői } \\
\text { bürokrácia / } \\
\text { szakértői modell }\end{array}$ & $\begin{array}{l}\text { gátolt és } \\
\text { szűk }\end{array}$ & $\begin{array}{l}\text { explicit, egyéni, } \\
\text { tudományos tudás }\end{array}$ & $\begin{array}{l}\text { a tudás magas } \\
\text { szinten formalizált }\end{array}$ & $\begin{array}{l}\text { közös tudásbázis } \\
\text { kialakítása, } \\
\text { repozitórium }\end{array}$ \\
\hline $\begin{array}{l}\text { adhokrácia / } \\
\text { munkavállalók } \\
\text { közössége modell }\end{array}$ & $\begin{array}{l}\text { radikális és } \\
\text { dinamikus }\end{array}$ & $\begin{array}{l}\text { rejtett, egyéni, } \\
\text { környezethez } \\
\text { kapcsolódó, } \\
\text { gyakorlati tudás }\end{array}$ & $\begin{array}{l}\text { tacit tudás } \\
\text { kiemelkedik, erős } \\
\text { közösségi hatás }\end{array}$ & $\begin{array}{l}\text { emelt szintű } \\
\text { lehetőségek (pl. } \\
\text { kollaboráció, } \\
\text { peer-review, } \\
\text { játékok stb.) }\end{array}$ \\
\hline $\begin{array}{l}\text { J-szervezet / } \\
\text { szervezetek } \\
\text { közössége modell }\end{array}$ & $\begin{array}{l}\text { kapcsolódó } \\
\text { és } \\
\text { halmozódó }\end{array}$ & $\begin{array}{l}\text { rejtett, kollektív, } \\
\text { szervezeti } \\
\text { folyamatokban } \\
\text { rejlő tudás }\end{array}$ & $\begin{array}{l}\text { decentralizált és } \\
\text { együttmüködő } \\
\text { probléma megoldás, }\end{array}$ & $\begin{array}{l}\text { tudás- } \\
\text { reprezentáció } \\
\text { tananyagok által }\end{array}$ \\
\hline
\end{tabular}




\begin{tabular}{|c|c|c|c|c|}
\hline & & & $\begin{array}{l}\text { tacit tudás átvétele } \\
\text { és gyüjtése }\end{array}$ & \\
\hline $\begin{array}{l}\text { gépi/ipari } \\
\text { bürokrácia / } \\
\text { bürokratikus } \\
\text { modell }\end{array}$ & $\begin{array}{l}\text { lehatárolt és } \\
\text { felszínes }\end{array}$ & $\begin{array}{l}\text { explicit, kollektív, } \\
\text { kodifikált tudás }\end{array}$ & $\begin{array}{l}\text { tanulás felületes } \\
\text { megközelítése, tacit } \\
\text { tudás ellenőrzése }\end{array}$ & $\begin{array}{l}\text { vizsgáztatás, } \\
\text { „egyszerü” } \\
\text { tananyagok }\end{array}$ \\
\hline
\end{tabular}

A fent bemutatatott négy szervezeti forma különböző tanulási és innovációs képességekkel rendelkeznek, és e formák szorosan kapcsolódnak a tudás átadás (és a tanulás) különböző típusaihoz is. Ezt a 9. táblázatban foglaltam össze. (Lam (2000) magasabb szintü összehasonlításra alkalmazta a modellt, azonban szervezeti szinten is ismert jellemzőket és tudásfelhasználást határoz meg.) Az e-learning alkalmazásának szempontjából elmondható, hogy a bürokratikus szervezetektől indulva, a Jszervezeteken át, az adhokráciák irányába haladva, egyre magasabb szintü elearninges támogatás képzelhető el. Ennek megfelelően pedig egyre komplexebb tananyagok fejlesztésével támogathatók a szervezetek képzései.

A folytatásban (többek között) a fenti rövid társterületeket érintő kitekintések is segít megismerni és megérteni az e-learning tananyagfejlesztés ökoszisztémáját, valamint támogatja az egyes, a kutatásba bevont projektek értékelését, értelmezését. 


\section{KutATÁs - A PROBLÉMÁK FELTÁRÁSA, A MEgOLdÁSi FOLYAMAT DEFINIÁLÁSA, MAJD AZ EREDMÉNYEK ÉRTÉKELÉSE}

Az alábbiakban szisztematikusan definiálom a problémakört, amelyre hipotézisem szerint választ adhat a digitális tananyagok fejlesztése. A DSR elvárt tudományos módszertani szigorával mutatom be a ciklikus tananyagfejlesztés folyamatát, a fejlesztési folyamat részvevőit, az eszközöket és az eredménytermékeket.

Az elmúlt közel 10 év során, amióta e-learning tananyagok fejlesztésével foglalkozom több száz digitális tananyag elkészítésében vettem részt. Részvételem kiterjedt a tananyagfejlesztésekkel kapcsolatos szakértői paletta szinte minden elemére (lásd 3.3.3 fejezetben részletesen): A kezdetekben voltam tananyagok forrásanyagának vagy forgatókönyvének szerzője, tananyagok szerkesztője HTML kódban vagy tananyagfejlesztő szoftverrel (3.3.4 fejezetben részletesen), vagy egyszerübb grafikai feladatok végrehajtója. Később sok esetben pedig a fejlesztési projektek vezetője voltam és komplex képzési programokhoz kapcsolódó fejlesztések irányításáért is feleltem. Számos más esetben technológiai és e-learning módszertani szakértőként támogattam fejlesztéseket. E projektek összessége adja a kvalitatív kutatásom mintáit, amelyek kontextusba való beágyazottsága igen magas, míg elemszáma alacsony (Szokolszky, 2004).

Az alábbi ábrán időrendbe foglalva láthatók a beválogatott projektek.
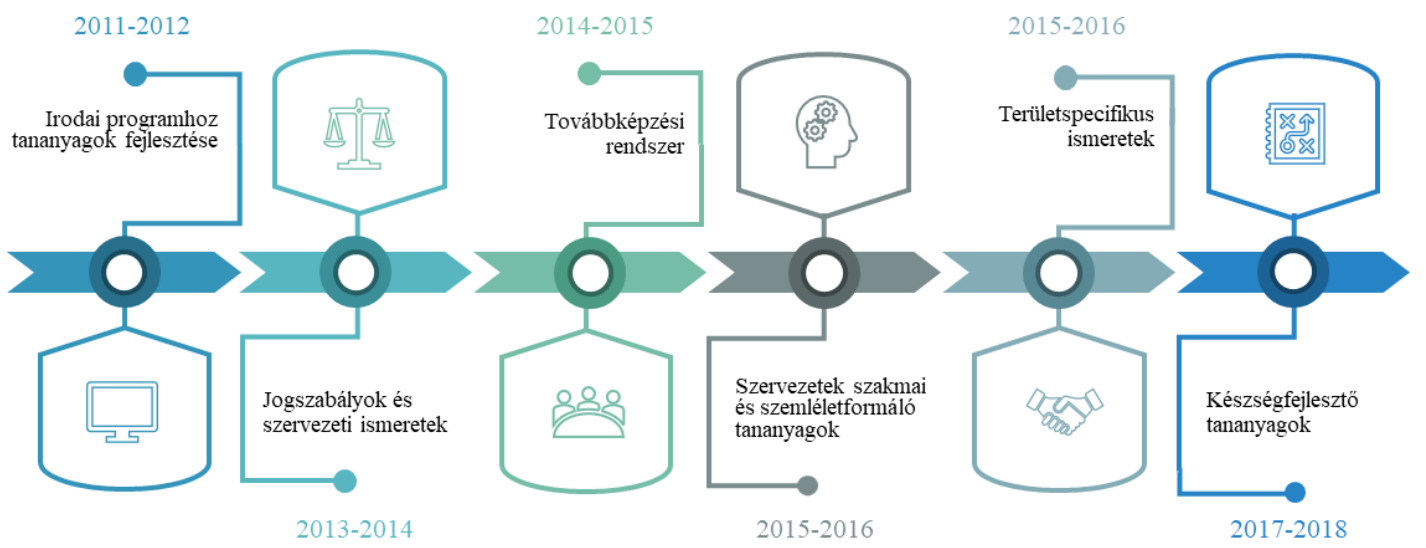

11. ábra-A kutatásba bevont e-learning tananyagfejlesztések idővonala (saját ábra 2018) 
A 11. ábrán időrendben összefoglalt projektek mintába emelése kapcsán az alábbi szempontokat vizsgáltam a disszertáció tükrében. (A titoktartási kötelezettségek miatt a projektek többségénél a partnerek nevének megjelölésére nincs lehetőségem.)

1. Az első az adott fejlesztés ,érdekessége”, vagyis az a tényező, amely kutatási (pl. akciókutatás) relevanciát adott a folyamat kialakításához és tovább gondolásához.

2. A második annak meghatározása, hogy a fejlesztési folyamat mely eleméhez kapcsolódó ismeretet nyújtott az adott projekt. Az ismétlődések elkerülése végett az azonos területeken történt fejlesztéseket nem válogattam be.

3. A harmadik szempont a kapcsolódás a disszertáció problémafelvetéshez, amely a kérdéskör vizsgálati lehetőségét adja.

4. A negyedik pedig a kutatási kérdésekhez kapcsolódás, vagyis, hogy milyen adatokat és konkrét ismereteket gyüjtöttem az adott projektből.

\subsection{A kutatás hátterének bemutatása - A hat fejlesztési projekt adatlapjai és a projektek összefoglalása}

Az e-learning új narratívaként ad eszközöket és platformot a tanítási és tanulási szituációknak olyan helyzetekben, amelyeket a hagyományos - jellemzően oktató termi - képzések már nem tudnak kezelni. Az új szervezeti és egyéni igények egy olyan keretet követelnek meg, amely túlmutat az eddigi gyakorlatokon és a képzéstervezés, képzésfejlesztés alapegységeként tekint az e-learning tananyagokra. Az e-learning a tanítási, tanulási problémákra nem csak digitalizált megoldásokat, hanem teljesen új megközelítéseket és módszereket nyújt.

Az alábbiakban egy-egy ,projektadatlap” olvasható a kutatásba bevont projektek esetében, ebben általánosan információk vannak a projektről, környezetéröl, eredményeiről. Ugyanitt mutatom be az adott projekthez kapcsolódó kutatásmódszertani elemeket is. Majd röviden összefoglalom az adott projekttel kapcsolatos következtetéseket. A projektek részletes, AR és/vagy CS szemléletü, leíró elemzése a mellékletben (6.1 fejezet) található.

\subsubsection{Irodai programokhoz tananyagok fejlesztése - a kezdeti ismerkedés a gyártási folyamattal}

A kutatásba bevont első projekt a tananyagfejlesztés egy szük területén, a gyártási szakaszban volt vizsgálható, az e-learning tananyagfejlesztési ökoszisztémájában 
elsősorban a kapcsolódó projektmenedzsment emelhető ki. E fejlesztés jó alapokat nyújtott a gyártás és az ezekhez köthető technológiákkal összefüggő megfigyelésekkel kapcsolatosan. A projektre szánt rövid határidő kapcsán már érzékelhetővé vált a tananyagfejlesztés sok résztvevős, komplex folyamatának nehézségei, lehetőségei. Összességében jellemző volt a „manufaktúra rendszer” szerinti gyártási folyamat kialakítása, amelyet a szakértök is kiemeltek, de saját megfigyelésem is ezt erősíti meg. Ez a gyártástechnika egyszerre teremt lehetőséget a nagy mennyiségü, de mégis az egyedi tartalomhoz igazodó gyártás levezényléséhez, fontos módszertani kötöttségek mellett (pl. teljesen azonos felépítésü tartalmak).

Projektadatlap - 2011-2012

Feladat leírása: $\quad$ Nagy mennyiségü, ugyanakkor eltérő típusú, előre gyártott tartalmi elemből volt szükséges összeállítani a tananyagokat. Összetett fejlesztési folyamat kialakítására és menedzsmentjére volt szükség, egyfelől az idő rövidsége, másfelől a résztvevők nagy száma miatt is.

Terület: versenyszféra

Tananyagok száma: $\quad 65+$

Részvevők száma ${ }^{11}$ :

15-20 fö

Célközönség: több ezer fö

PM modell:

vízesés

Eredménytermék(ek): scorm csomagok

Időtartam: 4 hónap Projekt értékelése: sikeres

Kutatói szerep: aktív részvétel, mint projektvezető

Kutatási módszerek $^{12}$ : megfigyelés, projektkommunikáció feldolgozása, mélyinterjú (I11.)

Újdonság: $\quad$ manufaktúra $\quad$ Megfigyelt $\quad$ szervezeti bürokratikus

Értékelési rendszer A tanulás értékelése valósult meg (beépített tudáspróbák által). szintje, megvalósítása:

\subsubsection{Jogszabályok és szervezetek ismertetése - egy speciális terület megismerése}

A kutatásba másodikként bevont projekt több speciális érdekességgel szolgált. Egyfelől lehetőséget adott, hogy egy egyedi - kifejezetten jogszabályismeretre vonatkozó - képzési területen készítsünk tananyagokat, másfelöl pedig a tananyag

\footnotetext{
${ }^{11}$ A résztvevők száma a teljes fejlesztési folyamatban résztvevő szakértők számát jelöli.

12 A mélyinterjúk esetében zárójelben találhatók az adott projekthez kapcsolódó interjúalany(ok) azonosítója. Lásd a melléklet 6.8 fejezete.
} 
jelentős mennyisége kapcsán a tananyagfejlesztési folyamat már kiegészült forgatókönyvírással. A feladatok jelentős része e projekt kapcsán is a gyártással volt kapcsolatos. Az ökoszisztéma tekintetében az eszközök, technológiák és a szereplök új körei emelhetők ki. Kifejezett érdekessége a projektnek, hogy noha maguk a tananyagok - a speciális téma kapcsán - „száraznak” mondhatók, mégis igen pozitív fogadtatásban részesültek. E pozitív fogadtatás kifejezetten az e-learning általános, „klasszikus” előnyeivel voltak összefüggésbe hozhatók: a tananyag időben és térben rugalmasan elérhető, nem volt szükséges az utazás, munkából kevesebb kieső időt igényelt. Összefoglalóan látható volt, hogy egy olyan szervezet esetében, ahol nincs korábbi e-learninges tapasztalat/tudás, ott a legkisebb ilyen irányú lépések is komoly előrelépést jelentenek az addigi merevebb, hagyományosabb képzési struktúrával szemben.

\section{Projektadatlap - 2013-2014}

\begin{tabular}{|c|c|c|c|}
\hline Feladat leírása: & $\begin{array}{l}\text { A jogszabályi tartalo } \\
\text { kidolgozása, és a tanany }\end{array}$ & $\begin{array}{l}\text { om szó szerinti alkalm } \\
\text { yagok teljeskörü fejlesztés }\end{array}$ & zásának módszertani \\
\hline Terület: & közszféra & Tananyagok száma: & $10+$ \\
\hline Részvevők száma: & $15-20$ fö & Célközönség: & több ezer fö \\
\hline PM modell: & vízesés & Eredménytermék(ek): & scorm csomagok \\
\hline Időtartam: & 6-9 hónap & Projekt értékelése: & sikeres \\
\hline Kutatói szerep: & aktív részvétel, mint pro & ojektvezető & \\
\hline Kutatási módszerek: & projekt dokumentáció f & feldolgozása, megfigyelés & \\
\hline Újdonság: & $\begin{array}{l}\text { „snippletek”, előre } \\
\text { legyártott tartalmi } \\
\text { elemek széleskörü } \\
\text { alkalmazása }\end{array}$ & $\begin{array}{l}\text { Megfigyelt szervezeti } \\
\text { modell }\end{array}$ & bürokratikus \\
\hline $\begin{array}{l}\text { Értékelési rendszer } \\
\text { szintje, megvalósítása: }\end{array}$ & $\begin{array}{l}\text { A tanulás értékelése } \\
\text { kérdések beépítésével). }\end{array}$ & valósult meg (egyszer & a tananyagba épített \\
\hline
\end{tabular}

\subsubsection{Továbbképzési rendszer - komplex és egyedi fejlesztési folyamat}

A kutatási ciklus egyik legjelentősebb, és legszélesebb körben megfigyelt, és dokumentált projektje volt egy kreditalapú továbbképzési rendszer számára készített száznál is több tananyag fejlesztése, amely esetében egy automatizált gyártási folyamat kialakításának lehetősége volt az újdonság. Továbbá - a projektben is résztvevő interjúalanyok (I4., I5. és I12.) által is kiemelten - egy jó együttmüködés 
modell alakult ki a módszertani megfontolások és a technológiai keretek kialakítása között: nem billent egyik irányba sem a fejlesztés, hanem szoros együttmüködés alakult ki. E projekt megfigyelése továbbá igen sok információval szolgálta ahhoz, hogy egy komplex és igazán szerteágazó e-learning tananyagfejlesztéshez milyen széleskörü résztvevői kört is szükséges, hogy mozgósítson az ökoszisztéma a módszertani szakértőktől, a programozókon át, a kreatív szakemberekig (pl. filmes kompetenciák stb.).

Projektadatlap - 2014-2015

\begin{tabular}{|c|c|c|c|}
\hline Feladat leírása: & $\begin{array}{l}\text { A több tízezres } \\
\text { tananyagmodul gyártá }\end{array}$ & $\begin{array}{l}\text { célközönség számára, töl } \\
\text { sa, rövid időtávon. }\end{array}$ & b tucat e-learning \\
\hline Terület: & közszféra & Tananyagok száma: & $100+$ \\
\hline Részvevők száma: & $35-40$ fö & Célközönség: & több tízezer fó \\
\hline PM modell: & prototípus & Eredménytermék(ek): & $\begin{array}{l}\text { egyedi videós } \\
\text { tananyagok }\end{array}$ \\
\hline Időtartam: & 12 hónap & Projekt értékelése: & sikeres \\
\hline Kutatói szerep: & aktív részvétel, mint e & -learning szakértő & \\
\hline Kutatási módszerek: & $\begin{array}{l}\text { projekt dokumentác } \\
\text { megfigyelés, mélyinte }\end{array}$ & $\begin{array}{l}\text { ó feldolgozása, zárótanu } \\
\text { rjúk (I5., I12.) }\end{array}$ & lmány feldolgozása, \\
\hline Újdonság: & $\begin{array}{l}\text { a gyártás } \\
\text { automatizálásához } \\
\text { kapcsolódó } \\
\text { standardizálás és } \\
\text { sablonok kialakítása }\end{array}$ & $\begin{array}{l}\text { Megfigyelt szervezeti } \\
\text { modell }\end{array}$ & bürokratikus \\
\hline $\begin{array}{l}\text { Értékelési rendszer } \\
\text { szintje, megvalósítása: }\end{array}$ & $\begin{array}{l}\text { A tanulás értékelése } \\
\text { kérdőívek) valósult m }\end{array}$ & $\begin{array}{l}\text { vizsgával), és az eredménye } \\
\text { g. }\end{array}$ & értékelése (interjúk, \\
\hline
\end{tabular}

\subsubsection{Közszféra szervezete számára szakmai tananyagok - szemléletformálás és játékos tartalom}

A kutatásba bevont negyedik projekt esetében kifejezetten a szerteágazó módszertani lehetőségek megfigyelésére, továbbá az ökoszisztéma „termék” ágának elemzésére volt lehetőség. Olyan multimédiás anyagok készültek a projekt keretében, amelyek mind-mind az adott témához kapcsolódóan lettek kiválasztva, és már megjelentek részben tartalmi elemei az e-learning by design szemléletnek is. Ugyanakkor a későbbiekben egyértelmủen zsákutcát jelentő eszközök, technológiák megfigyelésére is lehetőség nyílt. 
Projektadatlap - 2015-2016

\begin{tabular}{|c|c|c|c|}
\hline Feladat leírása: & $\begin{array}{l}\text { Szemléletformáló, } \\
\text { fejlesztése. }\end{array}$ & tékosos elemeket felv & nultató tananyagok \\
\hline Terület: & közszféra & Tananyagok száma: & 4 \\
\hline Részvevők száma: & 10-15 fó & Célközönség: & Több ezer fö \\
\hline PM modell: & v-modell & Eredménytermék(ek): & scorm csomagok \\
\hline Időtartam: & 3 hónap & Projekt értékelése: & részben sikeres \\
\hline Kutatói szerep: & \multicolumn{3}{|c|}{ aktív részvétel, mint módszertani szakértő } \\
\hline Kutatási módszerek: & \multicolumn{3}{|c|}{ megfigyelés, projekt dokumentáció feldolgozása } \\
\hline Újdonság: & $\begin{array}{l}\text { tananyagtípusok } \\
\text { keverése, } \\
\text { indítópultok } \\
\text { kialakítása }\end{array}$ & $\begin{array}{l}\text { Megfigyelt szervezeti } \\
\text { modell }\end{array}$ & bürokratikus \\
\hline $\begin{array}{l}\text { Értékelési rendszer } \\
\text { szintje, megvalósítása: }\end{array}$ & \multicolumn{3}{|c|}{ A tanulás értékelése (beépített tudásfelmérés és vizsga által) valósult meg. } \\
\hline
\end{tabular}

\subsubsection{Területspecifikus alap- és termékismeretek átadása - tantermi képzés átalakítása, kiváltása}

A nagyon általános „,erületspecifikus” ismeretek cím a titoktartási kötelezettség miatt ilyen, de a tananyag tartalmáról annyi elmondható, hogy egy szakmai terület, ügynöki értékesítésével kapcsolatos termék és tágabb alapismereteket átadását célozta meg a fejlesztés. Ez a projekt számos részében megfeleltethető az e-learning by design szemléletnek, és csak kevés ponton tért vissza „hagyományos” mederbe a fejlesztés. Jól strukturált tervezési ciklusok jelentek meg a folyamatban, és a szerteágazó résztvevői kör (pl. trénerek, e-learning szakértők széles köre stb.) lehetőséget adott egy innovatív fejlesztési folyamat kibontására. Kisebb nehézséget az jelentett, hogy kizárólag e-learninges formában tervezete a megbízó bemutatni az eredményeket, pedig a tartalom tekintetében voltak kifejezetten konzultációt és személyes képzést igénylő elemek. Emellett azonban mind e-learning módszertani, mind technológiai oldalról jól felépített, a különbözö tartalmakat jól kombináló végeredmény született. A fejlesztést pedig egy részletes kérdöíves felmérés követetett, amelynek eredményeit szövegbányászati módszerre vizsgálom a folytatásban.

Projektadatlap - 2015-2016 


\begin{tabular}{|c|c|c|c|}
\hline Feladat leírása: & $\begin{array}{l}\text { Több napos napos } \\
\text { fejlesztése, nagy menn }\end{array}$ & $\begin{array}{l}\text { enléti tréninget kiváltó, } \\
\text { ségű interaktív és multim }\end{array}$ & $\begin{array}{l}\text { komplex tananyag } \\
\text { iás tartalommal. }\end{array}$ \\
\hline Terület: & versenyszféra & Tananyagok száma: & 18 \\
\hline Részvevők száma: & 10-15 fó & Célközönség: & Több száz fó \\
\hline PM modell: & v-modell és prototípus & Eredménytermék(ek): & scorm csomagok \\
\hline Időtartam: & 3 hónap & Projekt értékelése: & sikeres \\
\hline Kutatói szerep: & passzív, megfigyelői ré & vétel & \\
\hline Kutatási módszerek: & megfigyelés, szövegbá & ászat & \\
\hline Újdonság: & $\begin{array}{l}\text { prototípusok } \\
\text { széleskörü } \\
\text { alkalmazása, komplex } \\
\text { tananyagokon átívelő } \\
\text { kerettörténet } \\
\text { alkalmazása }\end{array}$ & $\begin{array}{l}\text { Megfigyelt szervezeti } \\
\text { modell }\end{array}$ & $\begin{array}{l}\text { munkavállalók } \\
\text { közösségi modell }\end{array}$ \\
\hline $\begin{array}{l}\text { Értékelési rendszer } \\
\text { szintje, megvalósítása: }\end{array}$ & $\begin{array}{l}\text { A reakciók értékelése } \\
\text { tudásfelmérés és vizsg. }\end{array}$ & $\begin{array}{l}\text { nline kérdőív), a tanul } \\
\text { ltal) valósult meg. }\end{array}$ & rtékelése (beépített \\
\hline
\end{tabular}

\subsubsection{Készségfejlesztő tananyagok - egyénre szabott nagyvállalati tananyagok}

E fejlesztés egyik különlegessége, hogy belső elhatározásra, megbízó nélkül indult meg a fejlesztés, ezáltal számos kötöttségtől mentesen lehetett dolgozni. Maguk a forrásanyagok ugyan még nem az e-learning by design szemléletben készültek, azonban a termékek minden további eleme magán hordozta a kizárólag képernyő előtti tanulás lehetőségét. Az eredmények blended képzésekhez illeszthető, alapozó tudást átadó tananyagok, melyek teljes mértékben megállják önmagukban is a helyüket. A különböző „puha” készségek fejlesztését célzó tananyagok egységes kerettörténet szerint, számos játékos feladat mentén bontották ki a szakmai tartalmat, amely bőven lehetőséget adott a tanuló- és tartalomközpontú tananyag létrehozására.

Projektadatlap - 2017-2018

\begin{tabular}{|c|c|c|c|}
\hline Feladat leírása: & $\begin{array}{l}\text { Személyes és } \\
\text { digitális tanan }\end{array}$ & $\begin{array}{l}\text { készségeket fejlesztő, } \\
\text { id fejlesztése. }\end{array}$ & rettörténetbe ágyazott \\
\hline Terület: & versenyszféra & Tananyagok száma: & 8 \\
\hline Részvevők száma: & $<10$ fó & Célközönség: & Több száz fó \\
\hline PM modell: & I\&I & Eredménytermék(ek): & scorm csomagok \\
\hline Időtartam: & 15 hónap & Projekt értékelése: & sikeres \\
\hline
\end{tabular}




\begin{tabular}{|c|c|}
\hline Kutatói szerep: & $\begin{array}{l}\text { koncepcióalkotási szakaszban: aktív, szakértői részvétel, folytasában: } \\
\text { passzív, megfigyelői részvétel }\end{array}$ \\
\hline Kutatási módszerek: & projekt dokumentáció feldolgozása, megfigyelés, mélyinterjú (I2.) \\
\hline Újdonság: & $\begin{array}{llll}\text { standardizált } & \text { Megfigyelt } & \text { szervezeti } & \text { munkavállalók } \\
\text { gyártási folyamat, modell } & & \text { közössége modell } \\
\text { ellenőrzőlisták } & & \end{array}$ \\
\hline $\begin{array}{l}\text { Értékelési rendszer } \\
\text { szintje, megvalósítása: }\end{array}$ & $\begin{array}{l}\text { A reakciók értékelése (online kérdőív), a tanulás értékelése (beépített } \\
\text { tudásfelmérés alapján). }\end{array}$ \\
\hline
\end{tabular}

\subsection{Problémák azonosítása - a kutatás által megvizsgálni kívánt terület problématérképének felrajzolása}

A problémák azonosításához figyelembe vettem a fent bemutatott projektek eredményeit, megfigyeléseit, kiemelten ezek közül a „Területspecifikus alap- és termékismeretek" c. fejlesztéshez (lásd 3.1.5 fejezet) kapcsolódó DS szemléletủ problémafeltárás és megoldáskeresés eredményei. Ezen túl, 12 mélyinterjút folytattam (részletek a melléklet 6.8 fejezetében) - részben a projektek által megismert szervezetek - közepes vagy magas beosztású, emberi-erőforrás vagy képzési területen dolgozó munkatársaival, részben e-learning területén dolgozó szakemberekkel. Továbbá áttekintettem a kapcsolódó szakirodalmat, amelyet pár kivételtől (Sullivan, 2005) eltekintve jellemzően marketing anyagnak tekinthető blog bejegyzések (Andriotis, 2015; Gutierrez, 2017; Lipman, 2019) dominálják. Ezen ismereteket is beépítettem a gondolattérkép megrajzolása során kialakított eredménybe (3.2.2 fejezet).

Jelen pont a második kutatási kérdéshez (KK2) kapcsolódik, és ez adja a probléma relevanciáját, és a keresési folyamat első szakaszát is a DSR irányelvei mentén (lásd 1.5.3 fejezet hét irányelve).

\subsubsection{Gyakorlat és tudás - a problémafeltárás és bemutatása}

A DS szakirodalomban a problémákat (és a kapcsolódó megoldások keresését) Wieringa (2009) két típusba sorolja: gyakorlati problémák és tudás problémák. Míg az előbbi a „világ megváltoztatására törekszik a résztvevők igényei által” (Wieringa, 2009, p.2), addig az utóbbi esetében a résztvevők szeretnének valamit megtudni a világról. Az előbbire megoldásokat lehet keresni, míg az utóbbi esetében válaszokat. 


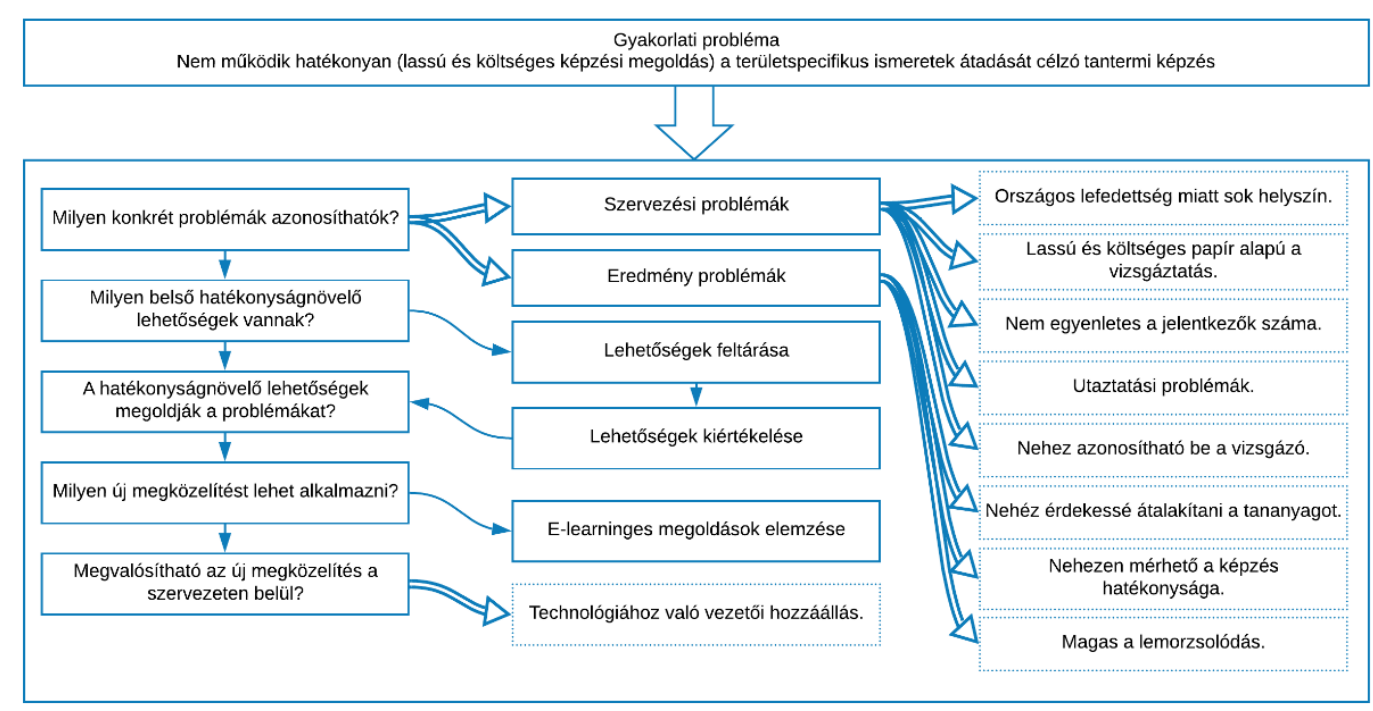

12. ábra - Problémák beágyazott feltárása (Wieringa, 2009) alapján (saját ábra 2019)

March és Smith (1995) nyomán a DS folyamatot gyakorlati problémák megoldásának tudományának tekintem. Ezért az egyik kutatásba bevont projekt által kidolgozott beágyazott problémamegoldási metódust követtem (Wieringa, 2009). Ennek vizualizációja a 12. ábrán látható. Ebben a szabályozó ciklus első lépésben megvizsgálja a problémát, több alkérdésre bontja, majd második lépésben megoldási javaslatot nyújt. A folyamat a javaslatot a harmadik lépésben pedig validál.

Jelen ponthoz a problémák alkérdésre bontása a lényeges lépés, a megoldási javaslat ezekre érkezett az e-learning tananyagfejlesztés képében. A harmadik, validációs lépés eredményeiről egy későbbi fejezetben számolok be, amikor a képzéshez kapcsolódó eredményeket és visszajelzéseket vizsgálom. A fenti elemzés mindemellett jó mintákat és problémaköröket azonosított egy konkrét fejlesztés kapcsán, amely jobb megközelítést ad a teljes problématérkép felrajzolásához.

\subsubsection{Gondolattérkép technika $\quad-\quad$ a megfigyelések és mélyinterjúk eredményeinek összegzése}

Az alábbi, 13. ábrán látható, a kutatás eredményeként felrajzolt térkép, amely 6 nagyobb problématerületen, összesen 23 problémát azonosít. Az ábrán a folyamatos nyíl elsődleges, közvetlen kapcsolatot jelent, míg a szaggatott nyíl az egymásra hatás eredményeként, másodlagos kapcsolatot jelent. A problémák pedig általános szintről indulnak (folytonos vonallal rajzolt négyzetek), és egyre konkrétabb nehézségeket, kihívásokat jelentenek (szaggatott, majd pontozott vonalakkal rajzolt négyzetek). 


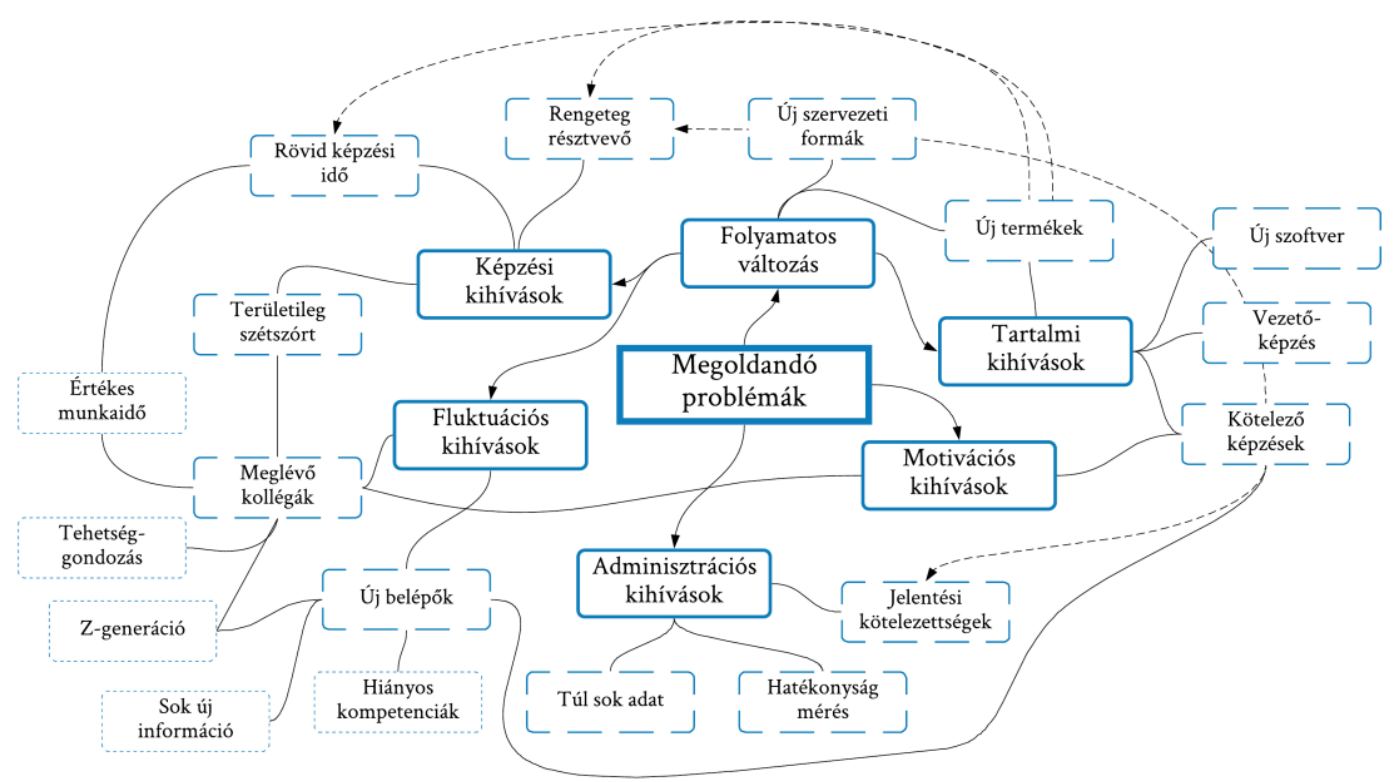

13. ábra - Szervezetfejlesztési és müködtetési problématérkép (saját ábra 2019)

A problémák azonosításához és kategorizálásához a gondolattérkép technikát alkalmaztam a saját megfigyelések és a mélyinterjúk során is. A gyüjtés során célom volt, hogy olyan problémákat tárjak fel, amelyekre az e-learning tananyagfejlesztés nyújthat (rész vagy egész) megoldást. Ehhez ennek megfelelő kérdéseket fogalmaztam meg az interjúk során.

A gondolattérkép készítése bevett módszer a tananyagfejlesztések során is, hiszen az átadni kívánt tudás a legtöbb esetben nem lineáris, egymást követő témák sorozata, hanem sokkal inkább egy központi elemre felfüzhető körkörös témagyüjtemény. Maga a gondolattérkép technika arra épít, hogy olyan kognitív eszközként tud müködni, amely mindkét agyféltekét megmozgatja (Mahmud és Veneziano, 2011).

„A gondolattérképek szervezett, az adott téma szempontjából strukturált kulcsszavakból épülnek fel, a középpontban áll a téma, mely köré csoportosulnak a részterületek, a fő témától a részletek felé haladva." (Habók, 2009, p.78). Alapvetően elég kevés konkrét szabállyal rendelkezik a gondolattérkép készítésének folyamata. Ennek köszönhetően is a kutatók széles körben alkalmazzák arra, hogy összetett információkat gyüjtsenek össze és mutassanak be. Emellett hatékony tanulási módszertanként is ismert (Crowe és Sheppard, 2012; Farrand et al., 2002).

Az elemzés során hat nagyobb kategóriát hoztam létre: 
1. Képzési kihívások: olyan problémák, amelyek kifejezetten a képzési területet érintik, mint a rövid képzési idő, rengeteg és területileg szétszórt résztvevő. Ezek a legtöbb esetben költségproblémaként merülnek fel. Több interjúalanyom (I2., I3., I8.) is kiemelte, hogy az egyik jelentős képzési probléma az egy före eső magas költsége a jelenléti képzéseknek sok terület esetén. A másik általános problémakör - amelyet megerősített egy nemzetközi nagyvállalat képzési vezetője is (I10.) - a nagy létszámú képzések. Az ö esetükben pl. e-learning tananyagfejlesztés csak a több száz, inkább ezres célcsoport számára készülhetnek. Gyártási területen a géptermi kapacitások is igen korlátozottak lehetnek (I9.), valamint a sok helyszín magában is korlátozó faktor (I3.).

2. Fluktuációs kihívások: itt a munkavállalókkal kapcsolatos nehézségeket tüntettem fel. Ezeket között kiemelt helyet foglal el a képzett munkaerő hiánya és a fluktuáció, mint ahogy arra rámutatott egyik interjú alanyom: „[...] a technológia maximálisan hatékony, a folyamatok tökéletesítve vannak, még az emberi erőforrást lehet kifeszíteni.” (I6.) A munkaerő megtartásában mindig fontos szerepet játszottak a vállalatok által kínálat továbbképzési lehetőségek (Demeter, 2009; Wentworth, 2014; Hámornik és Nagy, 2018). Ezekből pedig egyre több van, amelyet e-learning formátumban érnek el a munkatársak (De Smet et al., 2016). Az emberi erőforrás hatékonyságát pedig képzésekkel, egyéni fejlesztésekkel lehet növelni. Ezt a multinacionális telekommunikációs vállalatnál dolgozó alanyom (I3.) is fontosnak tartotta, kiemelte, hogy szükség lenne a tehetséggondozásra, jobban kiaknázni az egyéni képességeket. Ez nem csak a munkaerő megtartása tekintetében lényeges szempont, de a kimagasló eredményeket mutató munkatársak elismerésének és motivációjának is fontos hajtóereje lehet (Wong és Sixl-Daniell, 2017).

3. Adminisztrációs kihívások: azokat a kérdéseket gyüjtöttem itt össze, amelyek relevánsak lehetnek egy-egy tananyagfejlesztés kapcsán is. Ezekkel fontos tisztában lenni még akkor is, ha csak közvetett hatást lehet elérni. A kötelező képzések kapcsán - amelyek sok esetben az első lépések az e-learning tananyagok fejlesztésének világában - egy japán autóipari vállalat képzési munkatársa (19.) fejtette ki, hogy azt sem szabad elfelejteni, hogy új típusú kihívások jönnek elő pl. lesznek olyan munkatársak, akik ismételten nem végzik el az online elérhető képzéseket. 
4. Motivációs kihívások: leginkább a tanulókhoz, de az oktatókhoz, trénerekhez is kapcsolódó általános problémakör. A „life long learning” nem általános jelenség a magyarországi nagy szervezetek munkavállalói körében, így jelentős hangsúlyt kell fektetni a tanulási (és tanítás) motiváció megtalálásra, fejlesztésére. Direkt módon, a tananyagfejlesztés által szükséges és lehetséges kezelni ezeket a problémákat. Ezt az egyik e-learning szakértő interjúalanyom (I11.) úgy fogalmazta meg, hogy ahogy az audiovizuális ingerek iránti kereslet nő, úgy csökken a személyes interakciók igénye a fiataloknál.

5. Tartalmi kihívások: rengeteg tartalom képződik egy nagy szervezetben folyamatosan, az ezekkel kapcsolatos lehetőségek feltárása, a tartalmi ismeretek operatív tudássá váltása is fontos feladata lehet az e-learning tananyagfejlesztésnek. Egy interjúalanyom (I7.) az informatikai rendszerek használatával kapcsolatos nehézségeket emelte ki, hiszen egy-egy munkavállaló akár több tucat rendszert kellene, hogy ismerjen. Sok időt vesz igénybe, míg „belerázódik” valaki a munkába. Ezekhez kapcsolódott másik alanyom is, aki a felsőoktatásban dolgozik, és puha készségek fejlesztésének nehézségeit emelte ki. A multinacionális környezetben nagyvállalati képzési vezető pedig a törvényi előírás által kötelező képzéseket emelte még ki, amelyeket „nem kell túlcizellálni” (I10.). További, alapvető kihívást jelent a tartalom szakmai minősége, amelynek értékelése állandó feladat (pl. szakmai lektorálás).

6. Folyamatos változás: ez maga nem egyszer a mozgatórugója a problémáknak, mint ahogy a bevezető fejezetben is ismertettem. Manapság ez jól ismert jellemzője egy nagy szervezet müködésének.

E nagyobb kategóriák folyamatosan hatással vannak egymásra, és ezt kívánja reprezentálni az is, hogy a második szinten megfogalmazott problémák sok helyen összekapcsolódnak (szaggatott nyilak). A disszertáció fókusza miatt elsősorban azokat a problémákat, kihívásokat szerepeltettem az ábrán, amelyeknek közvetlen vagy közvetett kapcsolata lehet az e-learning tananyagfejlesztéssel, ezeken felül termesztésen számos egyéb kérdésre is választ szükséges keresni egy-egy nagy szervezet esetében.

Probléma E-learning tananyagfejlesztési megoldások összefoglalása 


\begin{tabular}{|c|c|}
\hline & $\begin{array}{l}\text { Az e-learning „klasszikus” előnyei érvényesíthetők digitális tananyagok } \\
\text { fejlesztése és a képzésbe történő bevezetése által, mint pl. az időtől és tértől } \\
\text { függetlenül elérhető tartalom, egyszerre végezheti a képzést akár több ezer fő. } \\
\text { Több szervezet esetében pl. (alsó) létszámkorláthoz van kötve az e-learning } \\
\text { tananyagfejlesztés vagy vásárlás. }\end{array}$ \\
\hline $\begin{array}{l}\text { Fluktuációs } \\
\text { kihívások }\end{array}$ & $\begin{array}{l}\text { Két direkt megoldást is kínálhat a tananyagfejlesztés: } \\
\text { 1. az új belépők tekintetében az e-learning tananyagok által átadhatók a } \\
\text { nagyvállalattal kapcsolatos általános ismeretek, illetve a területspecifikus } \\
\text { tudásanyagok is, mint pl. alkalmazott szoftverek stb. } \\
\text { 2. a meglévő kollégák esetében képzési lehetőségeknek lehet motivációs } \\
\text { tényezője - bár ez vagy a ,life long learning” nem nagyon jellemző a } \\
\text { magyarországi vállalatok munkavállalóira. A tananyagokból kinyerhető adatok } \\
\text { révén a tehetséggondozásban is lehetőség megtalálni a kimagaslóan teljesítő } \\
\text { munkatársak, valamint számukra új lehetőségeket nyitni (pl. magasabb szintű } \\
\text { tartalmak által). } \\
\text { Indirekt módon a tananyag pedig pl. a Z-generáció által elvárt formákban } \\
\text { reprezentálhat tanulási formákat: ilyenek pl. a multimédia túlsúlyú és } \\
\text { személytelenebb megoldások. }\end{array}$ \\
\hline $\begin{array}{l}\text { Adminisztrációs } \\
\text { kihívások }\end{array}$ & $\begin{array}{l}\text { Ezekhez a kihívásokhoz indirekt módon kapcsolódik a tananyag, azonban a } \\
\text { fejlesztés során fontos szempontokat jelentenek ezek kezelése, pl. a releváns } \\
\text { mérési pontok azonosítása, beépítése, és az ütemezett és átgondolt } \\
\text { hatékonyságmérés kialakítása. A jelentési kötelezettségek pontos ismerete és } \\
\text { akár automatizálása is olyan megoldások, amelyek, ha nem is számolják fel, de } \\
\text { segítenek enyhíteni a problémákat. } \\
\text { Itt említhetők még a költségekkel kapcsolatos hatékonysági elvárások is, pl. } \\
\text { ahogy egyik interjúalanyom rámutatott, a jelenléti képzéseken töltött „kieső } \\
\text { munkaidő költsége összehasonlítható az e-learning tananyagfejlesztés } \\
\text { költségével” (I11.), valamint további „klasszikus” tényezők, mint útiköltség, } \\
\text { teremköltség, tréner napidíj stb. is része lehet a költség-haszon elemzéseknek. }\end{array}$ \\
\hline $\begin{array}{l}\text { Motivációs } \\
\text { kihívások }\end{array}$ & $\begin{array}{l}\text { Általánosan megfigyelhető, hogy a kötelező képzések esetében - sokszor a } \\
\text { témák miatt is, pl. munka- és tűzvédelem - rendkívül alacsony a tanulói (és } \\
\text { oktatói) motiváció. Sajnos hasonlóan alacsony motiváció figyelhető meg pl. a } \\
\text { „puha” képességek fejlesztésével kapcsolatos, sok szervezetben elérhető } \\
\text { képzések tekintetében is. Éppen ezért a tananyagok fejlesztése során direkt } \\
\text { módon szükséges törekedni a célközönséghez illeszkedő megoldások } \\
\text { implementálására, amelyet adott esetben a tantermi képzésekhez képest már } \\
\text { önmagában az e-learning tananyaggal is elérhetünk, pl. szoftveroktatások } \\
\text { esetében. }\end{array}$ \\
\hline
\end{tabular}




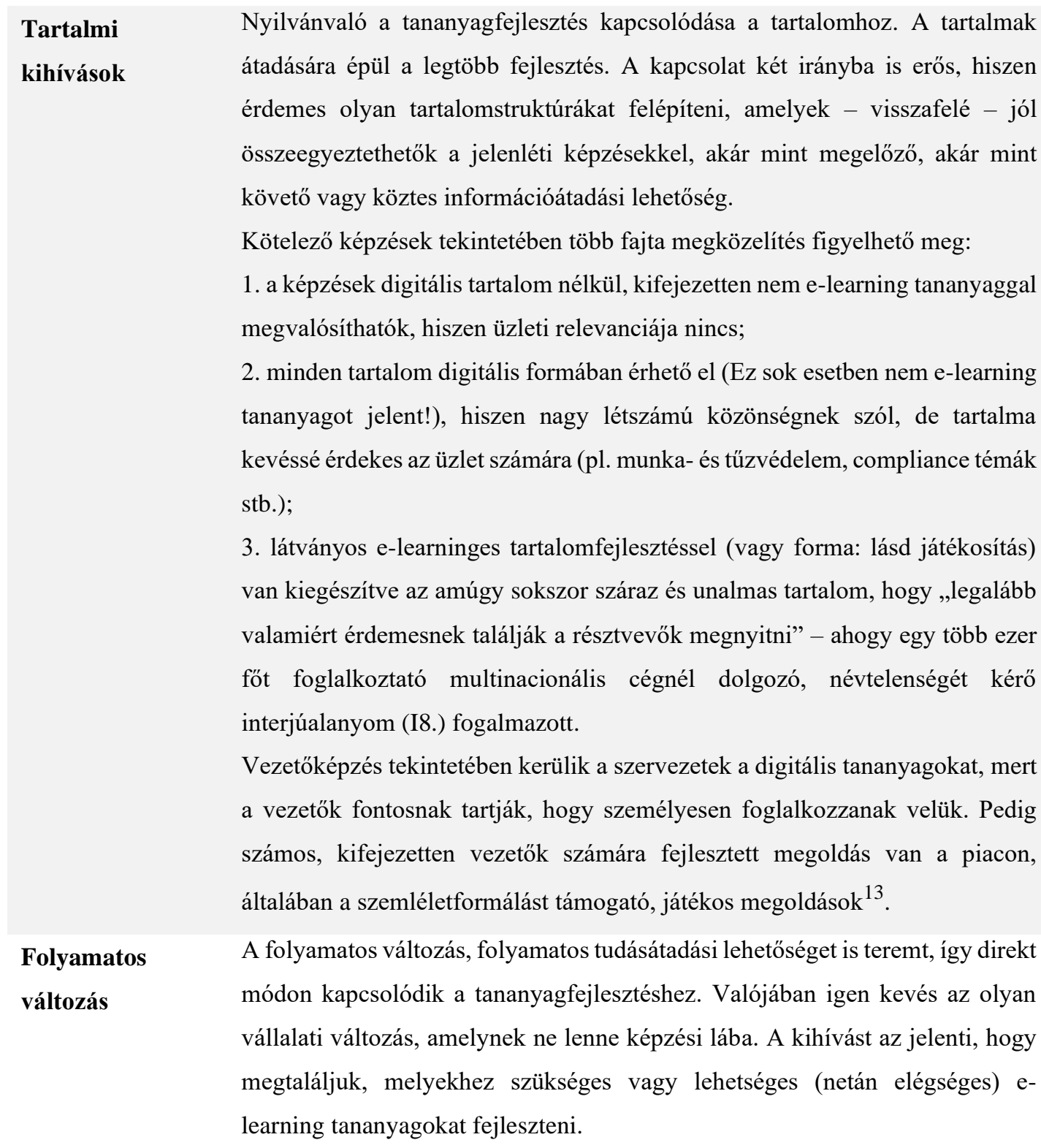

A fent részletezettek egy része kifejezetten az ún. elvetemült problémák táborát erősítik, amelyeket a DSR relevancia ciklusában találhatunk meg. A válaszok keresése vagy a megoldások tervezésében, már a design ciklusban, fontos szerepet játszhatnak a váratlan megoldások. Ezek kreatív, interaktív, sok tervezéssel járó folyamat eredményeként segíthetnek, ebben pedig része lesz a termékeknek, a kulcsszereplőknek és a technológiának is.

\footnotetext{
${ }^{13}$ Pl. a magyar fejlesztésü Fligby: https://www.fligby.com/ vagy a LabX által fejlesztett Extreme Event: https://labx.org/extreme-event/
} 


\subsection{Megoldás konstruálása - (1.) a tananyagfejlesztési folyamat felépítése, (2.) a termék, (3.) kapcsolódó szerepek és (4.) eszközök bemutatása}

A DSR módszertani elvei a megoldás konstruálása során csak irányelveket, útmutatókat tudnak megfogalmazni, konkrét megoldási javaslatok vagy folyamatelemek erre a szakaszra nincsenek (Offermann et al., 2009). A disszertáció e részében a közel egy évtizedes, a tananyagok fejlesztésében szerzett tapasztalatomra és az akciókutatási szemlélettel kikristályosodott, alkalmazott módszertanokra támaszkodom. Emellett az ezzel párhuzamosan folyó doktori képzésemre és a disszertáció készítése során kialakuló kutatásokra és eredményekre alapozom az alábbi megállapításaimat, reflektálva a szakirodalomban található jó gyakorlatokra. Ez az a tervezési folyamat, amely a DSR keret, mint terméket és kutatási értéket definiál (lásd 1.5.3 fejezet hét irányelve).

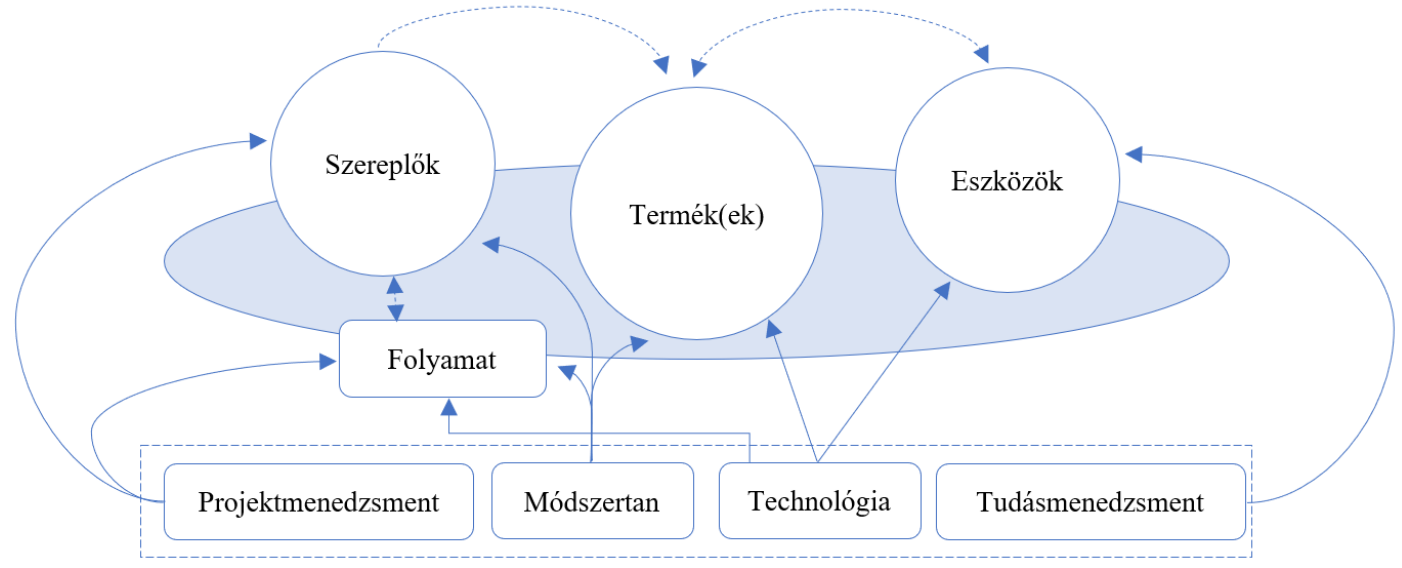

14. ábra - E-learning tananyagfejlesztés ökoszisztéma (saját ábra 2019)

A 14. ábrán látható ökoszisztémát jelen fejezetben az alábbi tagolása mentén mutatom be: folyamat, termékek, szereplők, eszközök. Ezek a megoldáshoz vezető legfontosabb elemek, amelyek ciklikus egymásra hatásai, és annak folyamatosan változó tartalmi és formai megújulásai mozgatják azt az ökoszisztémát, amelyet elearning tananyagfejlesztésként írhatunk le. Fontos kiemelni, hogy e négy elem, réteg vagy terület folyamatos kölcsönhatásban van egymással, és közben „önmagunkon belül” is folyamatos iterációt szükséges végrehajtani. Ezen egymásra hatások és ismétlődések, visszatérések (iterációk) müködtetik az ökoszisztémát, és alakítanak ki végül egy adott pillanatban, egy adott stabil eredményterméket. 


\subsubsection{Az öt-ciklus (5C) tananyagfejlesztés folyamata - Egy közel évtizedes kutatás eredménye}

A tananyagfejlesztés komplexitását már több szemszögből vizsgáltam a disszertációban. Ebben az alfejezetben részben e kutatási elemek összefoglalásaként, a KK3 kutatási kérdésre adandó válaszként foglalom össze az általam öt-ciklus (5C) e-learning tananyagfejlesztési folyamatnak elnevezett új tananyagfejlesztési modellt. Fontos lehatárolás, hogy az alábbi folyamat nem egy (teljes) képzés fejlesztésére vonatkozik, hanem kifejezetten egy e-learning tananyag fejlesztésére.

Ssz. Fejlesztés megnevezése

1. Irodai programokhoz tananyagok fejlesztése

2. Jogszabályok és szervezetek ismertetése

3. Továbbképzési rendszer

4. Közszféra szervezete számára szakmai tananyagok

5. Területspecifikus alap- és termékismeretek

6. Készségfejlesztő tananyagok

10. táblázat - Megfigyelt projektek és az új, 5C folyamattal kapcsolatos következtetések összefoglalása (saját táblázat 2019)

\section{Következtetések összefoglalása}

Világossá vált a koncepció készítésének, megismerésének fontossága, amely választ adhatott volna nem csak módszertani, hanem technológiai kérdésekre, nehézségekre is.

A folyamat vezetői szintről volt vezérelve, a tanulói szempontok háttérbe szorultak, rámutatva arra, hogy azok megismerésének fontosságára.

Több elöremutató tapasztalat alapján a kutatások és visszamérések területén, a ciklusok fontossága ebben a projektben jelent meg markánsan, és vált egyértelmüvé fontosságuk.

A ciklikus és iteratív fejlesztés előnyei itt is kiemelkedtek. Ugyancsak egyértelművé vált, hogy a prototípuskészítés is folyamatos, a fejlesztési folyamat során vissza-visszatérö feladat.

A projekt mutatott rá, hogy az utólagos felmérés már a következő fejlesztési ciklus előkészítése (lehetne), és ezért a tananyagfejlesztési folyamat nem lineáris.

A pontos tanulói igények felmérése és a kapcsolódó kutatások hiánya mutatott rá ezek fontosságára.

Az új, 5C tananyagfejlesztési folyamat konstruálásához elsősorban a 3.1 fejezetben bemutatott esettanulmányként feldolgozott és a megfigyelések tárgyát képező projektek tapasztalatait (lásd 10. táblázat), valamint a mélyinterjúk eredményeit és a tervezői szemlélethez kapcsolód szakirodalmat használtam fel. Az új folyamatot ezen kutatási elemek szintetizálása nyomán alakítottam ki. 
Összefoglalva az egyes szakaszokat és a legfontosabb információkat az alábbi, 11. táblázat tartalmazza.

\begin{tabular}{|c|c|c|c|}
\hline Szakasz & $\begin{array}{l}\text { Kapcsolódó } \\
\text { ciklusok }\end{array}$ & Kulcsszerepek $^{14}$ & Eredménytermék(ek) ${ }^{15}$ \\
\hline megismerés, feltárás & kulcsszereplö ciklus & tanuló & kutatási jelentés \\
\hline $\begin{array}{l}\text { megértés, földre } \\
\text { hozás }\end{array}$ & koncepció ciklus & e-learning szakértő & $\begin{array}{l}\text { tananyagfejlesztési } \\
\text { koncepció }\end{array}$ \\
\hline kitalálás, tervezés & design ciklus & $\begin{array}{l}\text { e-learning } \\
\text { designer }\end{array}$ & prototípus(ok) \\
\hline alkalmazás, gyártás & tanulási ciklus & gyártásvezető & tananyag (adott változtata) \\
\hline mérés, előkészítés & értékelési ciklus & tanuló & kutatási jelentés \\
\hline
\end{tabular}

A fejlesztési folyamat során a megoldandó problémákat, fejlesztési igényeket szükséges felmérni, akár a teljes szervezetről diagnózist készíteni (I6.), e lépés alkalmával feltérképezzük a képzés célját, azonosítjuk azokat az eszközöket és (akár módszertani, akár technológiai vagy projekt) korlátokat, amelyek megszabják a képzési célok teljesülését és végül felmérjük a tanulók nézőpontjait. E szakasz része a fejlesztéshez nélkülözhetetlen forrásanyagok beszerzése és ezek megismerése. Ez a megismerés, feltárás (1.) fázisa.

A következő lépésben kialakítjuk a fejlesztés koncepcióját, amelyben kitaláljuk és meghatározzuk az előzők alapján a módszertani és technológiai megvalósíthatóságára vonatkozó terveket, ez a megértés, földre hozás. (2.) Továbbá itt már mélyebb feldolgozásra kerül a forrásanyag, itt van lehetőség további szakanyagok bevonására, a fejlesztési koncepció kialakítására.

Ezt követi a kitalálás, tervezés (design) fázisa (3.). Ezen a ponton kiemelten fontos szempont az „e-learning by design” szemlélet. Ez egy kifejezetten kreatív fázis, amely során különböző lehetséges megoldási variánsokból kiválasztása kerülnek azok az elemek, amelyek megoldást nyújtanak a problémára, és beleférnek a módszertani, technológiai keretekbe. A kreativitás oldalirányú és divergens gondolkodással jellemezhető, amely lehetőséget ad arra, hogy a tervezők és a fejlesztők kilépjenek a

\footnotetext{
${ }^{14}$ Részletesen a 3.3.3 fejezetben.

${ }^{15}$ Részletesen a 3.3.2 fejezetben.
} 
meglévő keretek közül. Így teljesen új gondolatok mentén oldják meg a problémákat (Robinson, 2011).

A következő szakasz az alkalmazás, gyártás (4.), amely forgatókönyvírással, kiviteli tervek készítésével, a lehetséges szakmai tartalom módszertani, technikai és grafikai feldolgozásának különböző részleteinek kidolgozásával lehetséges megoldásokat alakít ki a különböző tananyagkomponensekre, akár darabonként, típusonként eltérő formában. A forgatókönyvek alapján indulhat meg a fejlesztői, gyártói munka, amely során az előzőekben létrehozott iránymutatások alapján elkészülnek a tartalmi és tanulást támogató elemek. E szakasz egyik kulcs-eleme a minél korábban elkészülő prototípus vagy prototípusok, amelyek egyfelől vizuálisan megjelenítik a tananyagot, másfelől pedig vizsgálják a technológiai megvalósíthatóságot (pl. LMS kompatibilitás). A prototípus készítése egy iteratív, kreatív, a megrendelővel szoros kapcsolatban zajló folyamat.

A fejlesztési szakasz zárásaként észrevételezési és átadási, visszamérési folyamatok következnek, és a következő ciklussal kapcsolatos előzetes tervezés is megindul: ez a mérés, előkészítés (5.). Az itt kapott visszajelzések alapján lesz lehetőségünk a problémák újra definiálására, további értelmezésére, majd a folytatásban újabb megoldási lehetőségek kidolgozására.

Az egyes szakaszok között és a szakaszokon belül fejlesztési ciklusok azonosíthatók. A fenti leírt szakaszok együtt egy idealizált folyamatot írnak le, amely egy következő szintje lehet a tananyagfejlesztésének. Jellemzője, hogy nem hagyományos véghatáridős, konkrét pénzügyi és egyéb erőforráskerettel határolt projektként tekint a fejlesztésre, amelynek jól meghatározott, és éppen ezek miatt minőségi korlátjai vannak. A leírt lépésegyüttes egy idealizált szemléletmódot képvisel, amelyben az egész képzés, és benne az e-learning tananyagok fejlesztése egy folytonos, ciklikusan fejlődő rendszer, és a szervezet szövetébe hatolóan vagy annak egyik fundamentumaként folyamatosan van jelen. Lásd még a tanuló szervezetekről szóló müveket (Senge, 1991; Slater és Narver, 1995; Serrat, 2017; Aly, 2017). E fenti szemléletben elmondható, hogy nincs kész tananyag, csak aktuális állapot.

A kutatásba bevont legutolsó projekt esetében felrajzolható egy lineáris folyamat, amely egy a gyakorlatban is megvalósuló fejlesztési folyamatot reprezentál, és az már összevethető az idealizált folyamattal. (A lineáris folyamat bemutatását lásd a melléklet 6.7.6 fejezetében, vizuálisan megjelenítve pedig ugyanott, a 24. ábrán.) 


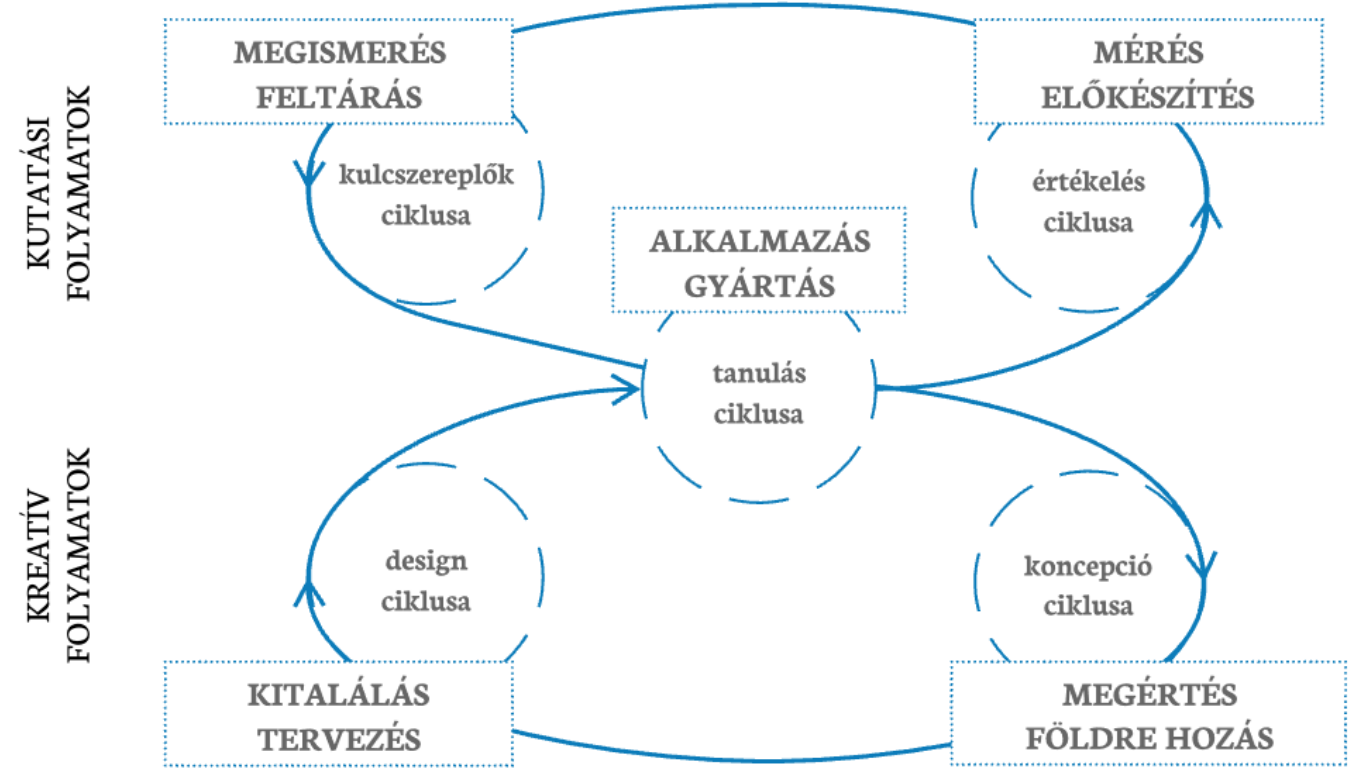

15. ábra - E-learning tananyagfejlesztés folyamata és belsö ciklusai (saját ábra 2019)

Ahogy a 15. ábrán látható, az általam meghatározott, 5C tananyagfejlesztési folyamat szakít a lineáris szemlélettel, és több, önmagába visszatérő ciklust definiál (kulcsszereplők, koncepció, design, tanulás és értékelés ciklusai). A fentiekben már rámutattam, hogy az egész tananyagfejlesztés egy olyan ökoszisztémában képzelhető el, amely folyamatos mozgásban van, és a fejlesztési ciklusok egymást követik. Ugyanez a ciklikusság a folyamat egyes fázisaiban is fontos hajtóerő és egymást mozgásban tartó folyamatokat kell, hogy eredményezzen. A központi ciklus - lehet, hogy magától értetődően, de a gyakorlatban mégsem - maga a tanulás kell, hogy legyen. Szándékosan nem szerepeltettem számozást az ábrán, mert az ökoszisztémán belül a különböző hatások akár indíthatják is a folyamatot a megismerés és feltárás fázisánál. Ugyanakkor megfigyelhető, hogy van már valamilyen adott tanulási ciklus, akkor először értékelni szükséges, hogy pontos információk birtokában lehessen megismerni és feltárni, kutatási folyamatok által, a problémákat, és elindítani egy új kreatív folyamatot. Ez a folyamat a koncepció és a konkrét termék(ek) tervezése, prototípusainak kialakítása, majd tesztelése. A kutatásba bevont fejlesztések esetében is látható, hogy általános belépési pont a kitalálás, tervezés szakasza, de éppúgy lehet belépési pont már a gyártás, alkalmazás szakasz is. Ezekben az esetekben általános, hogy a többi szakasz sem a projekt múltjában, sem jövőjében nem valósul meg. 
A fejlesztési folyamatot érdemes több szempont szerint szisztematikusan megvizsgálni. A folytatásban minden szakasz esetében az alábbi szempontokat fejtem ki:

1. gyakorlati megvalósítás nehézségei,

2. részfolyamatok és tevékenységek,

3. résztvevők és kulcsszerepek (további részletek a 3.3.3 fejezetben),

4. általános átfutási idő,

5. jellemző kockázatok és azok kezelési módjai,

6. köztes átadás-átvételi pontok és eredménytermék,

7. sikerkritériumok.

A folytatásban röviden összefoglalom a kutatások (megfigyelések, mélyinterjúk) eredményeként összegyült tapasztalatokat, a mellékletben (lásd 6.9 fejezet) pedig részletesen bemutatom az egyes szakaszokat a fenti nézőpontok szerint.

Összeségében elmondható a fenti folyamattal kapcsolatosan, hogy a gyakorlati megvalósítás tekintetében általános az erőforrás- és időhiány, ami nehézséget jelent a kreatív és sokszor többszörös iterációkból álló folyamatok számára. A részfolyamatok tekintetében jól definiálhatok azok a lépések, amelyek szükségesek, azonban fontos itt is meg-megújítani a berögzött megoldásokat. Számos résztevékenységet olyan kreatív tervezési technikák támogathatnak, amelyeket az ICT fejlesztések és felhasználói felülettervezések során alkalmazunk. Támogatás érkezhet a társadalomtudományos kutatások irányából is pl. interjú technikák, fókuszcsoportos kutatások stb. További eszköztár a webes tervezésböl származhat pl. a drótváztervezés, a felhasználói szereplők tervezése, a felhasználói felületek tervezése, hiszen „A technikai eszközök uralása szükséges a kreatív munkához, de önmagában nem elegendők.” (Robinson, 2011). A résztvevőket egy későbbi fejezetben (3.3.3 fejezet) külön is bemutatom, de fontos kiemelni, hogy közülük is az egyik legfontosabb szereplö az e-learning szakértő. Ő az, aki mind módszertani, mind technológiai oldalról tudja támogatni a fejlesztést, ért mind a tervezési, mind a gyártási fázis lépéseihez. A jellemző kockázatok között sokszor felmerül a nem elégséges idő ráfordítás, a szakterületek közötti együttmüködés nehézségei (pl. a módszertani oldal nem érti a technológiai kihívásokat, míg a fejlesztő nem tudja értelmezni a pedagógiai igényt) (I6.). Ezek kezelésére olyan megoldási lehetőségeket lehet alkalmazni, mint a részletekre kiterjedő dokumentálás, és komoly átadás-átvételi pontok rögzítés. Hasonlóan fontos 
minél több terület beemelése a megértési fázistól a tervezésig. Összességében pedig akkor tekinthetjük a tananyagfejlesztési folyamatot sikeresnek, hogy ha egyik oldalról megoldást kínál az azonosított szervezeti problémára, másik oldalról pedig olyan felhasználói élményt nyújt (legyen az tudásátadás, szemléletformálás, változás) a tanulók számára, amely az ő nézőpontjuk szerint is egyéni és szervezeti fejlődést jelent. Az egyes folyamatlépések részletes elemzése a melléklet 6.1 fejezetében találhatók.

\subsubsection{Termékek és tananyagtípus termékek összefoglalása - a fejlesztések „kézzelfogható" eredményeinek gyüjteménye}

A termékek szempontjából egyik oldalról a tananyagfejlesztésnek vannak kiemelendő rész termékei, amelyek nélkülözhetetlenek az eredményes $5 \mathrm{C}$ folyamathoz. A másik oldalról pedig a fö termék maga a fejlesztési folyamat végén az e-learning by design szemléletben elkészített tananyag. A folytatásban először a fejlesztési folyamat részeredménytermékeit veszem sorba, ezt követően pedig összefoglalóan bemutatom azokat a tananyagtípusokat, amelyek a különböző (a korábbi fejezetekben azonosított) problémák megoldásaként, mint a fejlesztések célja, „kigördülhetnek” a tananyagfejlesztési folyamatból, választ keresve a KK3-ra.

Az e-learning tananyagfejlesztési folyamat legfontosabb eredménytermékei:

\begin{tabular}{|c|c|c|}
\hline Elnevezés & Leírás & $\begin{array}{l}\text { Kapcsolódó } \\
\text { folyamatszakasz }\end{array}$ \\
\hline $\begin{array}{l}\text { Feltáró kutatási } \\
\text { jelentés }\end{array}$ & $\begin{array}{l}\text { A különböző - az adott körülményhez legjobban } \\
\text { alkalmazható - kutatási technikák eredményeit } \\
\text { összefoglaló jelentés, amely feltárja és azonosítja } \\
\text { a háttérben meghúzódó problémákat, segít a } \\
\text { fejlesztés céljainak azonosításában. }\end{array}$ & megismerés, feltárás \\
\hline $\begin{array}{l}\text { Tananyagfejlesztési } \\
\text { koncepció }\end{array}$ & $\begin{array}{l}\text { A felmérésekből, kutatásokból kialakított } \\
\text { igényeket és a tananyaggal szemben támasztott } \\
\text { követelményeket tartalmazó dokumentum, amely } \\
\text { azonosítja a fejlesztés céljait. }\end{array}$ & $\begin{array}{l}\text { megértés, földre } \\
\text { hozás }\end{array}$ \\
\hline $\begin{array}{l}\text { Forrásanyag } \\
\text { gyűjtemény }\end{array}$ & $\begin{array}{l}\text { A szakmai tudásanyag egy olyan jól strukturált } \\
\text { gyüjteménye, amely alapja tudás átadásának, a } \\
\text { szemléletformálásnak. Pl. korábbi előadások, } \\
\text { tankönyvi tartalmak, jegyezetek stb. }\end{array}$ & $\begin{array}{l}\text { megismerés feltárás } \\
\text { és megértés, földre } \\
\text { hozás }\end{array}$ \\
\hline
\end{tabular}




\begin{tabular}{|c|c|c|}
\hline Prototípus(ok) & $\begin{array}{l}\text { Olyan tervdokumentumok összessége, amely } \\
\text { terveket alakít ki a tananyag arculati, módszertani } \\
\text { és technológiai elvárásainak megfelelően a } \\
\text { koncepció mentén. (Pl. látványtervek, } \\
\text { drótváztervek, tananyag prototípusok stb.) }\end{array}$ & kitalálás, tervezés \\
\hline Forgatókönyv & $\begin{array}{l}\text { A prototípusok tapasztalatai alapján kialakítandó, } \\
\text { konkrét fejlesztési tartalmakkal ellátott } \\
\text { dokumentumok, amelyek a különböző típusok } \\
\text { esetében különböző formai megkötéseknek kell, } \\
\text { hogy eleget tegyenek. }\end{array}$ & alkalmazás, gyártás \\
\hline E-learning tananyag & $\begin{array}{l}\text { A forgatókönyvek alapján kialakított (aktuális) } \\
\text { tananyag, amelyből a tanulók már „éles” } \\
\text { környezetben is alkalmaznak (vagyis tanulnak). }\end{array}$ & alkalmazás, gyártás \\
\hline $\begin{array}{l}\text { Eredményesség } \\
\text { felmérő kutatási } \\
\text { jelentés }\end{array}$ & $\begin{array}{l}\text { A koncepcióban lefektetettek szerint felméri a } \\
\text { tananyag eredményességét és értékelését, és már } \\
\text { előkészíti a következő fejlesztési ciklushoz } \\
\text { kapcsolódó - korábban a feltárás során } \\
\text { azonosított eredményekhez hasonló - } \\
\text { problémákat, lehetőségeket stb. }\end{array}$ & mérés, előkészítés \\
\hline
\end{tabular}

Ahogy látható a 12. táblázatból a fejlesztési folyamat számos fontos - a tananyagon kívüli - eredményterméket is generál, amelyek egy része szorosan kapcsolódik a tananyagfejlesztéshez (pl. prototípusok, forgatókönyvek), más része pedig túlmutat azon (pl. feltáró és felmérő kutatási jelentések). Minden eredménytermék esetében kialakíthatók sablonok, és elkészítésükhöz különböző módszertanok és technikák köthetők (pl. a kutatási jelentések tekintetében: interjú technikák, kérdőív, fókuszcsoportos vizsgálat, megfigyelés stb. vagy a koncepcióalkotás esetében ötletelési technikák, a prototípusok esetében drótvázak és látványtervek készítése).

A Bloom-féle (1956) taxonómiát (melyet keretként lehet alkalmazni a tanítás módszertani megközelitése kapcsán) elöszeretettel alkalmazzák e-learning fejlesztések esetében is (Govindasamy, 2002; Halawi et al., 2009). A különbözö tanitási és tanulási célok eltérö megközelitéseket kívánnak eszköz és technológiai oldalról is. A disszertáció keretei között maradva, Lorin W. Anderson és munkatársai (2001) által újraértelmezetten, az alábbi,

13. táblázatban azonosíthatom a tanulási célokat. A különböző célokhoz különböző elearning tananyagtípusok alkalmazása javasolt, amelyek mind kialakíthatók a fejlesztési folyamat eredménytermékeként. 


\begin{tabular}{|c|c|c|c|c|}
\hline \multirow[t]{2}{*}{ Elnevezés } & \multirow[t]{2}{*}{ Képesség } & \multicolumn{3}{|c|}{$\begin{array}{l}\text { E-learning } \\
\text { típusok }\end{array}$} \\
\hline & & IMT & SZSZ & THSZ \\
\hline Emlékezés & Hosszú távú memóriából releváns tudás előhívása. & $\bullet$ & o & \\
\hline Értelmezés & Tanítási üzenetek jelentésének értelmezése. & $\bullet$ & $\bullet$ & ○ \\
\hline Felhasználás & Egy adott eljárást használata vagy végrehajtása. & ○ & $\bullet$ & \\
\hline Elemzés & $\begin{array}{l}\text { Az ismereti anyag szétszedése, majd az egyes elemek } \\
\text { közötti kapcsolatok megértése, általános célok } \\
\text { azonosítása. }\end{array}$ & $\bullet$ & & ○ \\
\hline Értékelés & Döntéshozás szabályok alapján. & o & & $\bullet$ \\
\hline Alkotás & $\begin{array}{l}\text { Teljesen eredeti gondolat alkotása, vagy a korábbi } \\
\text { ismeretek újszerü, koherens összeillesztése. }\end{array}$ & ○ & & $\bullet$ \\
\hline $\begin{array}{l}\text { - erős kapcsolat } \\
\text { o gyenge kapcsc }\end{array}$ & $\begin{array}{l}\text { IMT: Interaktív és multimédia } \\
\text { SZSZ: Szoftverszimulációs ta } \\
\text { THSZ: Történet alapú helyzet }\end{array}$ & $\begin{array}{l}\text { tanany } \\
\text { lanyag, } \\
\text { zimulác }\end{array}$ & $\operatorname{tana}$ & \\
\hline
\end{tabular}

13. táblázat - Eredménytermékek a tanulási célok nézöpontjából (saját táblázat 2019)

Az már a korábbi fejezetekből kiderül, hogy e-learning tananyagok tekintetében szigorú megkötéseket fogalmaztam meg, így tulajdonképpen az interaktív és multimédiás tartalom magától értetődő (akár kötelező) részei egy-egy e-learning tananyagnak. A fenti táblázatban és a korábbiakban az „interaktív, multimédiás tananyag” (IMT) tulajdonképpen „tananyagnak” is nevezheto,, de a pontosság kedvéért a hosszabb elnevezéssel hivatkozom. Az irodalomban ettől függetlenül megtalálható, hogy a szöveges, az interaktív és a multimédiás (pl. videós) tartalom külön-külön is értelmezhető (Poór et al., 2016). Ezt a megközelítést a gyakorlati tapasztalat is alátámasztja, azonban ez a nézőpont - meglátásom szerint tévesen sokszor a költség- és időhatékonyság dimenzióiban különbözteti meg a más és más különböző e-learning tartalmakat.

Az IMT-k alapvetően szöveges és illusztrációs tartalom alapúak, fontos kiegészítőik az olyan multimédiás elemek, mint a videók (amely az egyik legnépszerübb irány I2.), hangalámondás stb. Mind az interaktivitás, mind a multimédiás tartalmak mennyiségétől függően meghatározhatunk „alacsony” és „magas” megoldásokat tartalmazó tananyagokat. További pozitívum, hogy ha alkalmaz kerettörténetet az átadni kívánt tudással kapcsolatosan, de ez nem általános. A technológiai keretek lehetőséget adnak a különbözö tanulási útvonalak bejárására, egyéni tanulási utak 
kialakítására. Még további pozitív kiegészítője lehet az ún. „tanulótárs”, aki végig kíséri a tanulót az anyagon, és tanácsokat, segítséget nyújt. Ahogy a fenti táblázatban is látható, a legtöbb esetben minden, a tanulási célnak megfeleltethető tartalom előállítható ilyen formában. Jellemző felhasználási területek: új termékek, szolgáltatásokkal kapcsolatos ismeretek, kötelező képzések (pl. compliance, munkaés tüzvédelem stb.), de cél lehet akár készségfejlesztés is.

A szoftverszimuláció (SZSZ) típusú tananyag a speciális megoldás az ICT eszközök, azok funkcióinak készségszintre emelő tanítására. E tananyagtípuson belül is megkülönböztethetjük az egyszerübb, több képernyővideót és kevesebb interaktív szoftver-szimulációt tartalmazó típust (pl. ahol a tanuló kattintással, billentyűhasználattal kipróbálhatja az adott funkciót), és a fejlettebb, az előzőnél jelentősen interaktívabb formát. E tananyagok jellemzője a feliratozás és a narráció, amely segítheti a tanulást, egyszerre nyújtva vizuális és auditív ingereket is. A jó SZSZ tananyag modulja lehet a szervezet tudásmenedzsment rendszerének is, hiszen a szoftverhasználat (is) sok esetben nem azonnali, hanem visszakeresésre alkalmas tudást igényel. A fenti táblázatból látható, hogy ez a típus sokkal inkább az egyszerübb gondolkodási szintekhez kapcsolódó tanulási célokhoz kapcsolható.

Ugyan SZSZ által általában nem tudunk szemléletet formálni, de a történet alapú helyzet-szimulációs tananyag esetében már sokkal inkább a magasabb gondolkodási szinteket érintő tanulási célok azonosíthatók. Ez a típus sokszor filmes megoldással operál, és egy történetbe és/vagy helyzetgyakorlatba helyezi a felhasználót, ahol a szimulációt a tanulói döntések jelentik, és ezáltal a tanulók befolyásolhatják a történet előrehaladását. Az ilyen típusú tananyagok emelt szintje már közelebb áll egy-egy videójátékhoz, de nem szabad elfelejteni, hogy oktatási célja van. A fenti táblázatban is látható, hogy a magas szintü gondolkodáshoz kapcsolható tanítási célokhoz lehet alkalmazni, gyakorlati felhasználása pl. a szemléletformálás, a készségfejlesztés.

\begin{tabular}{llll} 
Terméktípus & Felhasználási terület & Speciális eszközigény & Speciális szerepe(k) \\
\hline Interaktív és & új termék/szolgáltatás, & e-learning & adott esetekben: \\
multimédiás tananyag & kötelező képzések, & tananyagfejlesztő & programozó, filmes \\
& készségfejlesztés & eszköz vagy egyéb & szakember, \\
& & webes technológiák & játékosítás szakértő, \\
& & animáció tervező
\end{tabular}




\begin{tabular}{llll|}
\hline Szoftverszimuláció & szoftverismeret és & speciális célszoftver & szervezet szakértője \\
\hline $\begin{array}{l}\text { Történet alapú } \\
\text { helyzetszimulációs }\end{array}$ & $\begin{array}{l}\text { szemléletformálás, } \\
\text { készségfejlesztés }\end{array}$ & filmes kellékek & filmkészítéshez \\
tananyag & & kapcsolódó \\
\hline
\end{tabular}

14. táblázat - Terméktípusok összefoglalása (saját táblázat 2019)

Ha a tanuláshoz való viszonyulást és a tanulás értelmezést vizsgáljuk, akkor megkülönböztethetjük Ollé János nyomán (Ollé, 2018) az információközvetitő, a szabályozott és a tudás- és nézetformáló tananyagokat. A fentiek közül az IMT legtöbb esetben információközvetítő: nagy mennyiségü tartalom átadásával kapcsolatosan támogatja és bevonja a tartalom „fogyasztásába” a tanulókat. Konstruktivista elemek alkalmazásával (pl. tanuló aktív bevonása, adaptív megoldások implementálása stb.) az IMT illeszkedhet a nézetformáló célokhoz is. Az SZSZ szabályozott tanuláshoz kapcsolható, egy-egy folyamatot gyakoroltat, és rendelkezik egy jól definiált tanulási útvonallal. A THSZ elsősorban attitűd formálási igénye kapcsán, általában a harmadik szinten van, tudás- és nézetformáló szempontokat tartalmazza. (Ollé, 2018)

A tananyagfejlesztés ökoszisztémájában a termékekhez speciális eszközök és kulcsszerepek kapcsolódnak. Míg az IMT esetében az adott felhasználási területhez, az interaktivitási és multimédiás szinthez kapcsolódik a speciális eszköz és kulcsszereplő igény, addig a szoftver-szimuláció és a helyzet-szimulációs anyagok esetében sokszor egyediek az eszközök és a kulcsszereplök. Ezekre térek ki összefoglalóan a következő fejezetekben.

\subsubsection{A fejlesztés kulcsszereplői - résztvevők és szerepek}

A fentiekben részletezett tananyagok esetében már látható, hogy a különböző fejlesztési célok és tananyagok esetében a résztvevők köre is eltérő. Ettől függetlenül az e-learning tananyagfejlesztés folyamatában azonosíthatók a közös kulcsszerepek. A folytatásban e szerepeket és szereplőket mutatom be, és elemzem a fejlesztésekre gyakorolt hatásukat és kockázatukat - válaszolva a KK4-re. 


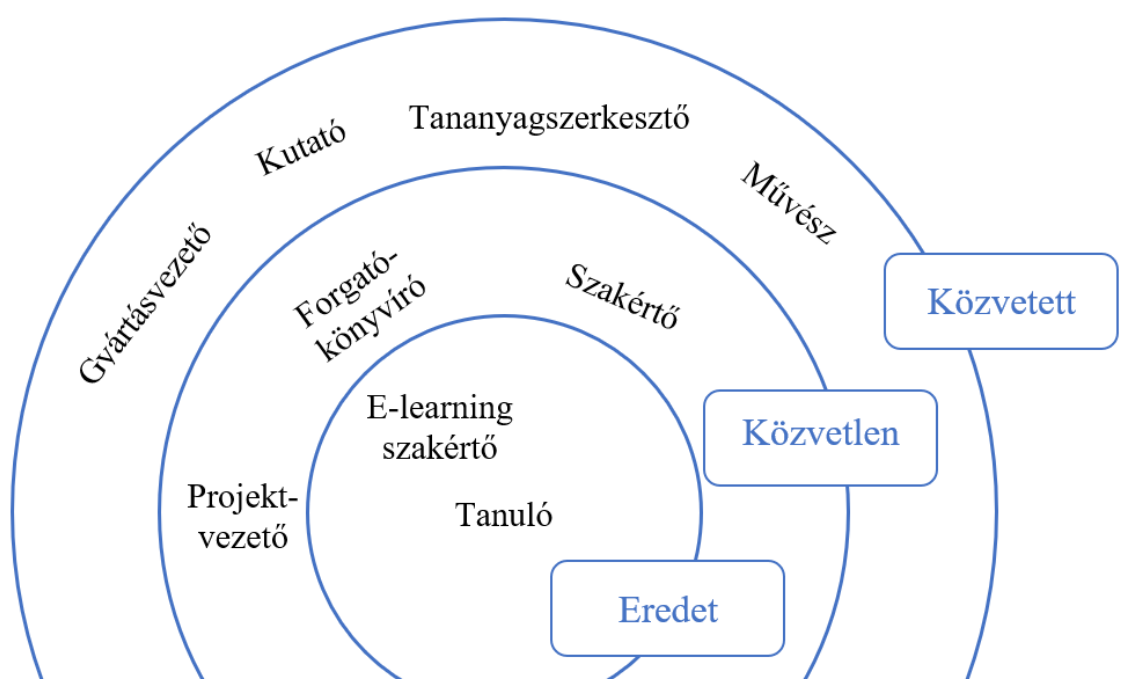

16. ábra - Kulcsszereplők bemutatása és hatásuk (saját ábra 2019)

\begin{tabular}{|c|c|c|c|}
\hline Kulcsszerep & Folyamat szakasz & Kulcskompetenciák & Végzettség \\
\hline E-learning szakértő & $\begin{array}{l}\text { megértés, földre } \\
\text { hozás } \\
\text { kitalálás, tervezés }\end{array}$ & $\begin{array}{l}\text { projektmenedzsment, } \\
\text { UX/UI ismeretek, „puha” } \\
\text { készség }\end{array}$ & $\begin{array}{l}\text { pedagógiai vagy } \\
\text { informatikai felsőfokú }\end{array}$ \\
\hline Forgatókönyvíró & $\begin{array}{l}\text { kitalálás, tervezés } \\
\text { alkalmazás, gyártás }\end{array}$ & $\begin{array}{l}\text { oktatási tapasztalat, } \\
\text { történetmesélési képesség }\end{array}$ & $\begin{array}{l}\text { pedagógiai közép- } \\
\text { vagy felsőfok }\end{array}$ \\
\hline Gyártásvezető & alkalmazás, gyártás & $\begin{array}{l}\text { projektmenedzsment, } \\
\text { webes technológiák, } \\
\text { UX/UI ismeretek }\end{array}$ & $\begin{array}{l}\text { informatikai közép- } \\
\text { vagy felsőfok }\end{array}$ \\
\hline Kutató & $\begin{array}{l}\text { megértés, földre } \\
\text { hozás } \\
\text { mérés, előkészítés }\end{array}$ & $\begin{array}{l}\text { kvalitatív és kvantitatív } \\
\text { módszertani ismeretek, } \\
\text { tanulótípusok ismerete }\end{array}$ & $\begin{array}{l}\text { társadalomtudományi, } \\
\text { pszichológiai } \\
\text { felsőfokú }\end{array}$ \\
\hline Müvész & alkalmazás, gyártás & $\begin{array}{l}\text { adott területhez } \\
\text { kapcsolódó kimagasló } \\
\text { müvészi képességek }\end{array}$ & - \\
\hline Projektvezető & teljes folyamat & $\begin{array}{l}\text { magas szintü } \\
\text { projektmenedzsment } \\
\text { ismeretek, magas szintű } \\
\text { „puha” képességek (pl. } \\
\text { kommunikáció, } \\
\text { időmenedzsment, } \\
\text { csapatmunka stb.) }\end{array}$ & $\begin{array}{l}\text { informatikai vagy } \\
\text { pedagógia felsőfokú }\end{array}$ \\
\hline
\end{tabular}




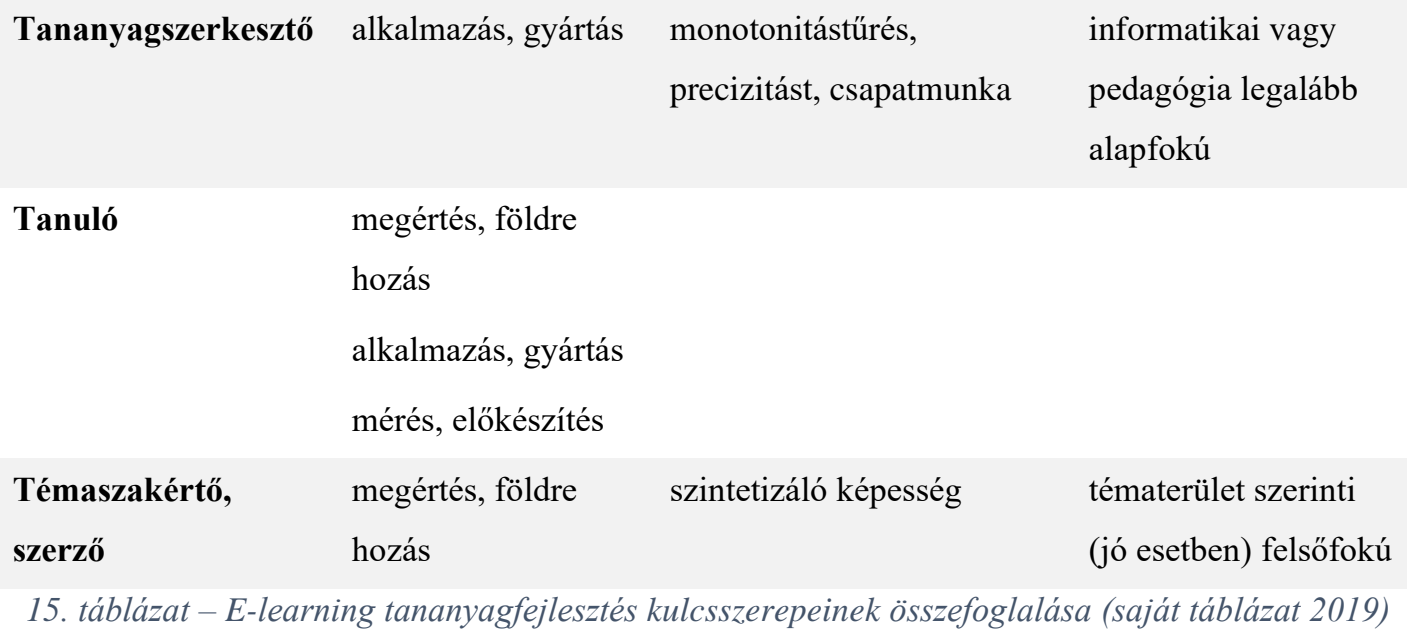

A fentieken a kulcsszereplők abc sorrendjében haladok végig, kifejezve azt is, hogy nincs a szerepek közöttük „fontossági” sorrend. A projektek gyakorlati lefolyását az jellemzi, hogy több kulcsszerepet sokszor ugyanazok a személyek töltik be, pl. az elearning designer és a forgatókönyvíró megegyezik, vagy a projektvezető és a gyártásvezető személyes azonos. Sőt, a legegyszerübb fejlesztések során szinte az összes szerep „mögött” egy személy található. Azonban ahogy a folyamatok elemzésekor, úgy itt is egy idealizált helyzetből indulok ki. Egyfelöl a különböző szerepekhez különböző kompetenciák tartoznak, másfelől ezzel is hangsúlyozom, hogy a tananyagfejlesztés kreatív folyamatában szinte kötelező a csapatmunka (Boyle, 1997; Hughes és Hay, 2001) és a szereplők széles körének bevonása („Több szem, többet lát.”).

A szakirodalomban és az angolszász gyakorlatban ismert az „instructional designer” (ID) - akit módszertani szakértőnek vagy oktatástervezőnek lehetne magyarul hívni. Ez a szereplő tervezi meg, és találja ki a tanulási, tanítási folyamatot. Sok projektmenedzsment, felhasználói felület tervezési, akár forgatókönyvírói és számos „puha” készségre (pl. kommunikáció, csapatmunka stb.) is szüksége van a munkája során. Ezeket kiegészítve (legalább alapszintű) technológia- és eszköz-ismeretekkel, nevezem általánosan e-learning szakértőnek azt a szereplőt, aki a tananyagfejlesztés egy adott szakaszával kapcsolatos minden e-learning szakmai feladatot el tud látni. E kulcsszereplőnek egyben „e-learning designernek” kell lennie, hiszen munkája kreatív és általában a tervezési szakaszokban aktív. Ehhez legközelebb a „learning experience designer” elnevezésű szakértő áll közel az irodalomban (González, 2018). Sok esetben egy-egy szakértő inkább módszertani vagy technológiai oldalról rendelkezik nagyobb 
tapasztalattal, így egy adott projekt esetében érdemes mindkét terület szakértőjére támaszkodni, ami adott esetben e-learning szakértői csapatokat is jelenthet egy-egy projekt esetében.

A klasszikus ID feladatok tágan értelmezve tartalmazzák a forgatókönyvírást is, de a tapasztalataim szerint elönyös, hogy ha külön tudunk azonosítani olyan forgatókönyvírót is, akinek van gyakorlati oktatási tapasztalata és ugyanakkor történetmesélésben jártas, kreatív szakember. Feladatkörének célja, hogy - az elearning szakértővel szorosan együttmüködve - narratívát és keretet adjon a tanulásnak, további feladata, hogy részleteibe menően megtervezze az egyes szöveges tartalmakat pl. párbeszédeket, történeteket.

Gyártásvezetőként olyan szakértőt azonosítottam a folyamatokban, aki az adott eszközöket és technológiát és a gyártási feladatok teljes spektrumát minden részleteiben ismeri. Feladata, hogy segítse a megbízó szakértőit és a tananyagszerkesztőket és a tartalomgyártó „művészeket”.

A kutató kulcsszerepet, mint gyüjtőkategória használom, hiszen a különböző kutatási szakaszokhoz és az azokon belül azonosítható feladatokhoz különböző szakértőkre (pl. pszichológus (I4.), adatbányász stb.) van szükség. A kutató a célok, célközönség megismerésére, majd az eredmények szisztematikus vizsgálatában vesz részt, és szolgáltat olyan eredményekkel, amelyek nélkülözhetetlenek az e-learninges tanítást és tanulást tervezői számára.

A müvész szereplőt is egy gyüjtőkategóriaként alkalmazom, mert számos tananyagelem gyártása kreatív szakemberek részvételével történik, mint grafikus, animáció készítő, filmes forgatókönyvíró, rendező, színész stb. A tananyagok kinézete a tanuló első benyomása, és lehetőséget kell, hogy adjon elmélyülni a tanulásban. Ez az egyik legfontosabb értékelési szempont is (I2., I6., I10.). A „művész” kategóriába tartozhat egy kreatív programozó is, aki informatikai oldalról teszi lehetővé a tanulást. Illetve e „művész” csoportba értelmezhető az előbbiek munkájukat támogató szakemberek, akik ugyanúgy egy-egy tananyagfejlesztés részvevőivé válhatnak: hangmérnök, operatör, sminkes stb. Meglátásom szerint fontos szempont itt is, hogy ők is tisztában legyenek a fejlesztés céljával, és a fejlesztésre vonatkozóan az $e$ learning by design szemlélettel dolgozzanak. Pl. fontos tudni, hogy általában nem célja egy tananyagfejlesztésnek, hogy kisjátékfilm minőségü mozgóképes tartalmak készüljenek, hiszen nem mozivászon előtt tekintik majd meg a tanulók az anyagot, 
hanem pl. a mobil telefonjuk kijelzőjén. Ez keretezheti egy operatőr kreatív feladatait az egyes jelenetek beállítása tekintetében.

A projektvezető az a kulcsszereplö, aki az egész tananyagfejlesztési folyamatot átfogja, és menedzseli a rengeteg szereplőt, továbbá klasszikusan felel a határidők és az erőforrás keretek betartásáért. Tapasztalataim szerint akkor eredményes a munkája, hogy ha projektvezető egyben e-learning szakértői tapasztalatokkal is rendelkezik, ez nagyban segíti a fejlesztések eredményességét és minőségét.

A tananyagszerkesztő, aki elöállítja magukat az e-learning tananyagokat (sajnos gyakran) minimális módszertani ismeretekkel rendelkezik, ami megfigyelésem szerint hiba egy-egy tananyagfejlesztés során. A legjobb koncepciók, forgatókönyvek és tervdokumentációk is tartalmazhatnak „fehér foltokat”, amelyet a gyártás során szükséges „feltölteni”. Ezeket pedig a szerkesztő látják meg elsőként, így érdemes módszertani felkészítésben részesíteni az e szerepet betöltő munkatársakat.

A tanuló, bár neki készül a tananyag, az ő fejlődése talán a legfontosabb mozgatórugó, igen kevés esetben érintett a klasszikus fejlesztési folyamatban. Az általam vázolt folyamatban azonban központi és kulcsszerepet tölt be, nem csak a kutatási, hanem a kreatív-tervezési fázisokban is, mint a design iterációk egyik fajsúlyos értékelöje. Fontos figyelni a „rossz” és a ,jó” tanulókra (I1.), a különböző tanulási szokásokat szükséges figyelembe venni, és beépíteni.

A témaszakértő, szerző is kulcsrésztvevője egy-egy fejlesztési folyamatnak, hiszen az a tudás, az ismeret stb., amelynek átadásán dolgozik egy egész csapat, leginkább az ő fejében van meg eredetileg, ott áll össze, ő tudja definiálni a szakmai kérdéseket, és ő validálja szakmailag a tananyagokat. A témaszakértő lehet egy tutor, egy tréner, egy egyetemi oktató stb. vagy (tipikusan nem az oktatás világa felől delegálva) egy-egy terület szakembere, szakértője. Jellemző szerepére, hogy sokszor inkább sajátjának érez egy-egy fejlesztést, mint a többi résztvevő, pedig a szerep a folyamat egy szakaszára összpontosul. Sok esetben a témaszakértő nem rendelkezik e-learning szakértői tudással, és nehezen valósítja meg az e-learning by design szemléletet. 


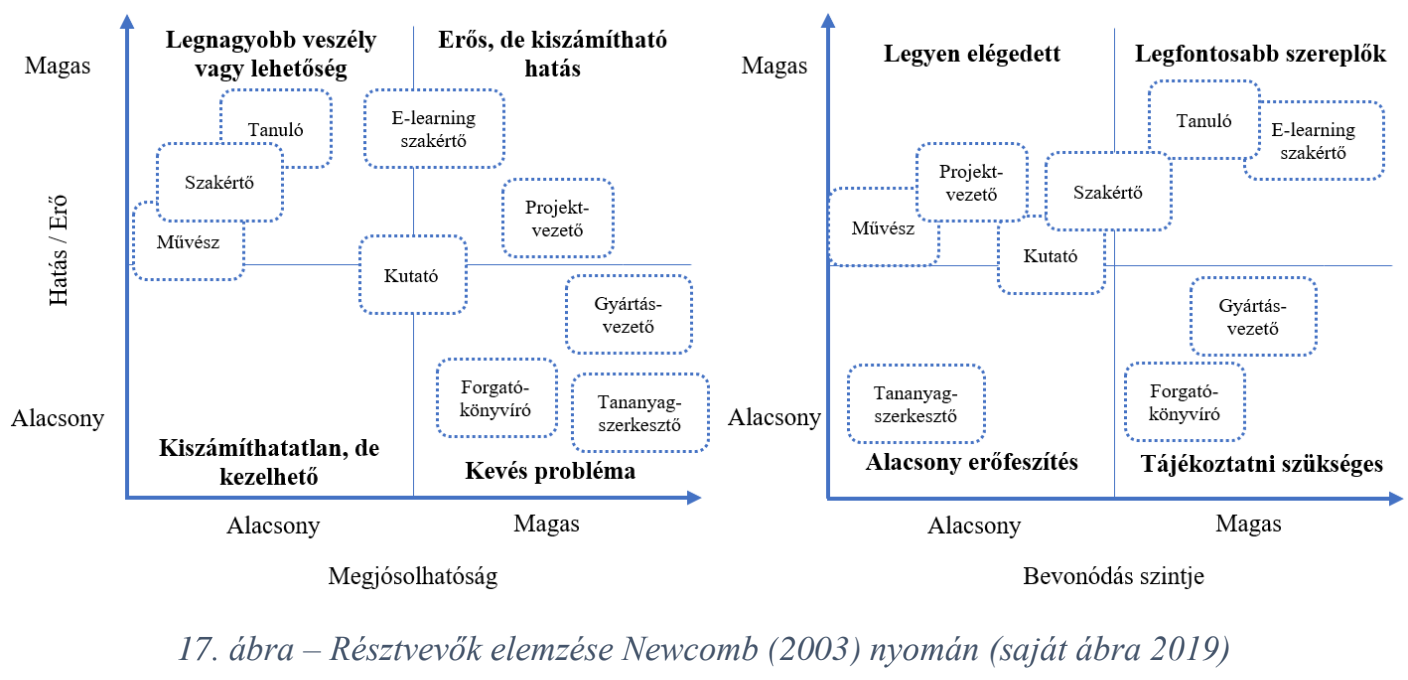

A résztvevők esetében (Scholes et al., 2002) alapján Newcombe három kérdésére kerestem a választ, hogy általános képet rajzolhassak fel a résztvevők erőviszonyaival kapcsolatosan:

a) „Mennyire valószínü, hogy egy adott kulcsszereplö érvényesíti az elvárásait?” (Newcombe, 2003, p.844)

b) Rendelkeznek-e az adott kulcsszereplök azokkal az eszközökkel, amelyekkel érvényesíteni tudják az elvárásaikat?

c) Milyen hatással lehetnek az adott kulcsszereplők elvárásai a későbbiekre? (Newcombe, 2003)

A kérdésekre adott válaszok eredményeként jött létre a fenti 17. ábra, amely egyfelöl az egyes kulcsszereplők esetében azt mutatja be, hogy milyen hatásuk lehet a fejlesztésre, másfelöl pedig a fejlesztésben betöltött szerepükre világít rá. A kockázatok tekintetében a fejlesztésre a legnagyobb kockázatot a tanuló, a témaszakértő és a művész jelenthetik, kisebb mértékben az e-learning szakértő, hiszen hatásuk jelentős, de viselkedésük megjósolhatatlan lehet. Ennek ellenpontján áll a tananyagszerkesztő, forgatókönyvíró, gyártásvezető, akiknek a hatása kisebb és munkájuk megjósolható. Ahogy az ábra jobb oldalán is látható a legfontosabb szerepek a fejlesztés szempontjából a tanuló, az e-learning szakértő és a témaszakértő. Velük a legfontosabb a gyakori kapcsolattartás és véleményük folyamatos bevonása, ők a mindenkori „támogatók”.

A projektvezetőt és a témaszakértők egy részét, a müvészeket és a kutatókat is folyamatosan érdemes bevonni. Cél, hogy ezek a szereplők elégedettek legyenek a 
fejlesztéssel, mert hatásuk igen jelentős, bár az e-learning elkötelezettségük és bevonódásuk alacsony, ők jó esetben a külvilág felé „láthatatlanok”.

Azonban amennyiben elkötelezettségük a fejlesztés iránt növelhető, úgy akár jelentős támogatói, hozzájárulói is lehetnek a végeredménynek. A gyártásvezetőnek és a forgatókönyvírónak általában alacsonyabb hatása van az előző résztvevőknél, de legtöbb esetben igen elkötelezettek és jól bevonhatók a fejlesztésbe, érdemes időrőlidőre kikérni a véleményüket, és benne tartani a folyamatban. Ök lehetnek a projekt „védelmezöi”.

A legkisebb hatása és a legkisebb bevonódása is a tananyag-szerkesztőnek van, mégis a termék minősége szempontjából fontos a munkájuk. Ezért, még ha sok esetben „közönyösnek” is tekinthetők, érdemes azon dolgozni, hogy bevonódásuk magasabb legyen (Mendelow, 1991).

\subsubsection{A fejlesztés eszközei és kapcsolódó technológiák - mivel készítünk e- learning tananyagokat?}

Az e-learning tananyagfejlesztési ökoszisztéma utolsó fontos eleme a tananyagok elkészítéséhez alkalmazható, konkrét szoftveres, informatikai megoldások soksasága, azok számbavétele. Az eszközök nem csak önmagukban érdekesek, hanem általánosan is megfigyelhető, hogy sok esetben a technológiai és a módszertani kérdések „összecsapásából” a technológia kerekedik felül, és a fejlesztés nem a legjobb módszertani, hanem a legjobb technológiai megoldás irányába halad. Ez a fajta technológiai determinizmus kitapintható az e-learning tananyagok fejlesztésével kapcsolatosan, és egyre növekvő az ezzel kapcsolatos kritikus szakirodalom is (Oliver, 2011).

Az elmúlt évek kutatómunkája során több tucat alkalmazást vizsgáltam meg, és értékeltem a folytatásban kifejtett módszertannak megfelelően. Ezek közül az alábbiakban négy olyan komplex tananyagfejlesztő alkalmazást mutatok be, amelyek versenytársai egymásnak, és egyértelmű „nyertest” lehet hirdetni, kapcsolódva ezzel a harmadik kutatási kérdéshez (KK3) is. Az egyes eszközök, szoftverek esetében a terjedelmi korlátot miatt a szoftverek adatlapja a mellékletben található (lásd 6.10.6 fejezet). Az alábbiakban az eredmények összegzése található. 


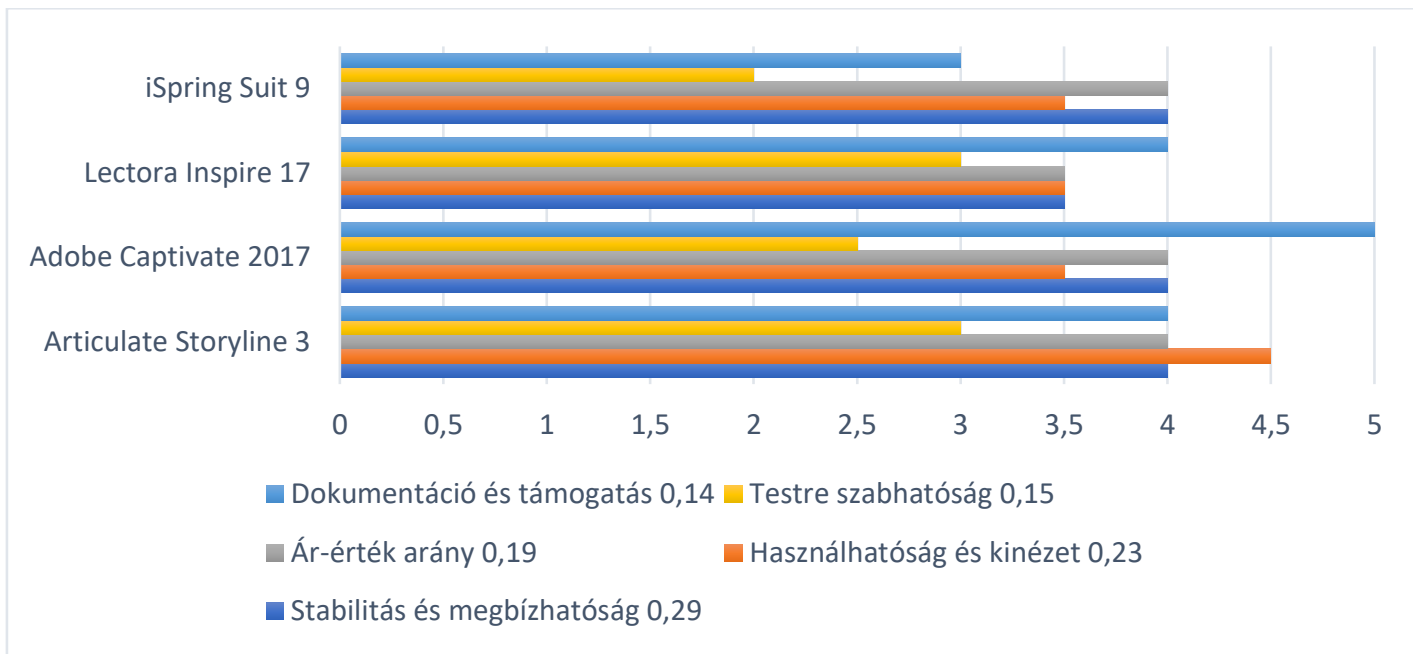

18. ábra - E-learning fejlesztő eszközök összehasonlitása (saját ábra 2018)

A komplex tananyagfejlesztő szoftverek közül a következöket vizsgáltam: Articulate Storyline 3, Adobe Captivate 2017, Trivantis Lectora Inspire 17, iSpring Suite 9.

A 18. ábrán összefoglalt e-learning tananyagfejlesztő eszközök kipróbálása és elemzése azt eredményezte, hogy a korábban bemutatott projektek legtöbb esetben az Articulate Storyline 3-mal készültek. Összeségében elmondható, hogy a fenti eszközök bármelyikével magas színvonalú e-learning tananyagok készíthetök. Mind a négy szoftver a jelenlegi e-learning fejlesztő eszközök legtöbb tudásával felvértezett, legerősebb eszközei közül kerültek ki, és alkalmasságukat bizonyították az elemzések során is.

Ahogy a tananyagok definiálása során is látható volt, úgy az eszközök meghatározása esetében is egy széles és folyamatosan bővülő palettáról lehet választani. Már az elearning fejlesztő eszközök definíciója esetében sem egységes a szakirodalom. Az egyszerübb eszközök és kurzuskészítő (course authoring) megoldások (Guralnick és Levy, 2009) vagy tanulási elemek összeillesztésére alkalmas komplex eszközöket is találunk (Gallego et al., 2013). Ide sorolhatók olyan szoftverek is, amelyek segítségével egy-egy kurzus állítható össze (Elkins és Pinder, 2015). A többség végül sok próbálkozás alapján választ, felsőoktatási környezetben általában nyílt megoldásokat (Giacumo és Conley, 2015).

A fentiek fényében és a saját tapasztaltok alapján, az e-learning fejlesztő szoftver esetében az alábbi jellemzőket találtam kulcsfontosságúnak:

- közvetlenül a polcról elérhető (commercial off-the-shelf, COTS) kereskedelmi megoldás legyen, 
- a fejlesztések eredménye egy LMS-be szabványosan implementálható tartalom legyen (lásd SCORM),

- a szoftver komplexitása révén adjon lehetőséget arra, hogy olyan tartalmat lehessen vele elöállítani,

○ amely alkalmas arra, hogy a tanulók belemélyülhessenek a tanulásba,

○ amely megfelelö felhasználói környezetben, amely megfelel a modern arculati és felhasználói felületektöl elvárt követelményeknek,

○ és amely további tanulási élményt nyújt pl. játékos, multimédiás és interaktív tartalmak révén.

A fenti szempontok betartása garantálja, hogy ilyen, professzionális eszközök alkalmazásával valóban professzionális tananyagok fejlesztésére kerüljön sor. Csak nagyon speciális esetekben van létjogosultsága pl. saját fejlesztésű vagy kifejezetten cél-eszközöket és ezekhez illeszkedő e-learning kereteket alkalmazni. A folytatásban bemutatom azt a kutatási folyamatot is, amely eredményeként kiválasztásra kerültek azok az általános eszközök, amely alapjai lehetnek az e-learning tananyagfejlesztésnek. Továbbá az e hatterében húzódó folyamat (lásd a melléklet 6.10 fejezet) bemutatása mintaként szolgálhat más tananyagfejlesztési projektek esetében a megfelelő szoftverek kiválasztásához.

A megfelelő COTS szoftverek kiválasztásához számos módszertant meghatározott már a szakirodalom, ld. többek között Javed és munkatársai (2012) és Garg (2017) áttekintését. Termesztésen minden megközelítésnek megvannak az előnyei és hátrányai, de sok módszertan indul ki abból, hogy az eszközökkel szemben támasztott követelmények már a vizsgálódást megelőzően rendelkezésre állnak. Jellemző a módszertanokra, hogy egyetlen termék kiválasztását irányozzák elő, valamint „klasszikusnak” tekinthető döntéselméleti módszertanokkal operálnak. Ilyenek pl. a súlyozott pontozási módszer (Weighted Scoring Method, WSM), illetve a többszempontú döntési problémák megoldására alkalmas sajátvektor módszer (Analytic Hierarchy Process, AHP), amely „lehetővé teszi a döntési feladatok logikus rendszerbe foglalását" (Temesi, 2002, p.120) (Garg, 2017). A fenti modellek legtöbb esetben abból a feltételezésböl indulnak ki, hogy egy adott problémára, vagy funkciókészletre keresnek a vállalatok COTS megoldást. A keresés három stratégia mentén valósul meg: 1. rengeteg szoftverből egy iteratív folyamatot követően választjuk ki az alkalmazható eszközt az ún. előremutató szürés (progressive filtering) 
esetében. 2. a keresés az alapok azonosításával kezdődik (keystone identification). 3. egy összerakós elemként tekinthetünk a szoftverre, amennyiben feltételezzük, hogy az illeszkedése központi kérdés, vagyis integrálható-e a szoftver a folyamatba, vagy elkülönül (puzzle assembly) (Javed et al., 2012). A folytatásban kifejtésre kerülő értékelési rendszer ez utóbbiként, egy összerakós rejtvény egyik elemeként tekint a szoftverekre, miközben erősen támaszkodik az alapokra, kevésbé követve az első pontban leírt szürési stratégiát. Az előző fejezetekben definiált tananyag-fejlesztési folyamat lehetőséget kell, hogy teremtsen a puzzle elemek folyamatos felülvizsgálatára, és adott esetben cseréjére.

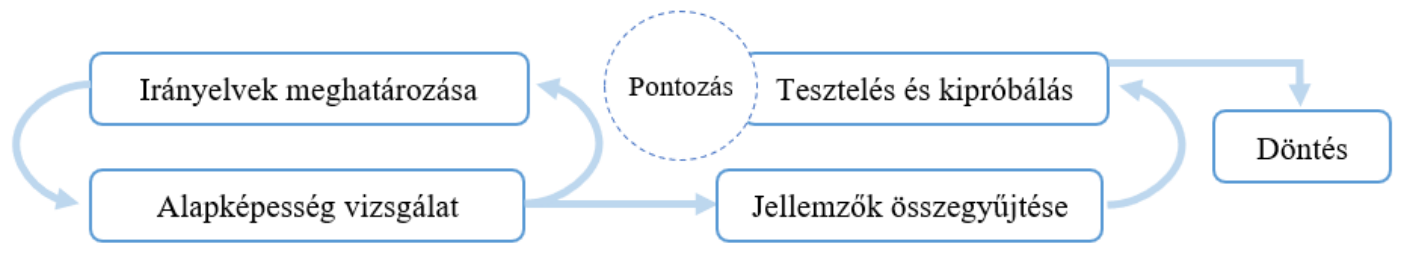

19. ábra-E-learning tananyagfejlesztés eszközeinek kiválasztása (saját ábra 2019)

A folytatásban a 19. ábrán bemutatott, saját módszertan kialakításához figyelembe vettem a PECA (Comella-Dorda et al., 2002) és a STACE modell (Kunda és Brooks, 2003) javaslatait, kifejezetten szem előtt tartva az e-learning tananyagfejlesztési folyamat sajátosságait. Tapasztalataim és a fenti módszertanok alapján az egyes eszközök alkalmasságának megítéléséhez az alábbi folyamatot konstruáltam, amely négy fázisból áll:

1. Alapképességvizsgálat, amely alapján egy rövid ellenőrzőlistával összevetve megállapításra kerül egy eszközről, hogy teljesíti-e azokat az alapvetéseket, amelyeket - többek között - a korábbi fejezetekben részletesen bemutattam:

a. az eszközkompatibilis (Futtatható-e azon az operációs rendszeren és egyéb szoftverkörnyezetben, amelyen alkalmazni kívánjuk?),

b. az eszköz friss (Mivel alapvetően informatikai eszközökről van szó, ezért csak olyan eszközöket vizsgáltam, amelyek az elmúlt 2 évben frissültek legalább 1 alkalommal, így aktív, friss eszköznek tekinthetők.),

c. szabványos tananyagok előállítására alkalmas,

d. a kereskedelmi felhasználás biztosított.

2. Jellemzők összegyüjtése, amely lépés során kategorizálásra kerül az adott szoftver elsősorban a felhasználás szempontjából. Az alábbiakat szükséges 
összegyüjteni: kereskedelmi felhasználás pontos részletei, árazás, gyártó megbízhatóságának értékelése (szakmai múlt és ismertség, verziófrissítés gyakorisága alapján), terméktámogatás formái, alkalmazhatóság vagy felhasználási cél lehatárolása (e-learning tananyagtípus fejlesztéséhez vagy a fejlesztési folyamathoz kapcsolódik-e az adott eszköz), eredménytermék meghatározása.

3. Tesztelés, kipróbálás fázis során vagy minta tartalmakkal, folyamatokkal vagy egy pilot projekt kapcsán demonstrálható az éles müködés. E folyamatban minél több hibát és téves felhasználási megoldást érdemes beilleszteni, mert sok esetben a termékek erre adott válaszai alapján ítélhető meg egy eszköz. Fontos, hogy az adott termék kipróbálásába és tesztelésébe minden olyan résztvevő bevonásra kerüljön, akik alkalmazni fogják az adott eszközt. A szisztematikus vizsgálódás során az alábbi területeken szükséges pontozni az eszközöket:

- stabilitás és megbízhatóság: bonyolult, összetett müveletek, vagy nagyobb adattartalmak kapcsán szükséges ellenőrizni a szoftver müködését.

- használhatóság és kinézet: ma már alapvetés egy szoftver esetében, hogy „könnyen kezelhető” és a felhasználói felület „letisztult”, azonban ezek megléte vagy pontos megvalósulása minden esetben komolyan vizsgálandó és értékelendő. Szükséges figyelembe venni azt is, hogy mennyire könnyü megismerni, megtanulni az adott eszköz használatát.

- ár-érték arány: ez az értékelési pont nagy részben fakadhat a tananyagfejlesztési folyamatban betöltött szerephez kapcsolódóan, illetve általánosan a szoftver felhasználási céljaihoz.

- testre szabhatóság: amennyiben konkrét e-learning tananyag típushoz kapcsolódik, úgy a „végeredmény” egyediségét is érdemes vizsgálni, amennyiben a folyamatot támogató eszközről van szó, úgy fontos a széles szakértői kör minden tagja által használható eszköz biztosítása, és ehhez lehet kulcsfontosságú az eszköz testre szabhatósága.

- dokumentáció és támogatás: feltérképezni és értékelni szükséges az elérhető dokumentációs lehetőségeket, támogató szolgáltatásokat és azt a közösséget, amely egy adott szoftver használ. 
4. Az utolsó fázis a vizsgálódás kiértékelése, és döntés az adott szoftver, eszköz használatáról, amelyben az előző fázisban kalkulált pontérték mellett az egyéni, szubjektív megítélés is fontos faktor.

Maguk az e-learning eszközök legtöbb esetben a tervezés/fejlesztés, kiajánlás/bemutatás és elérés/megjelenés három fö kategóriáiba sorolhatók (Horton és Horton, 2003), amelyek sok esetben nem függetlenek egymástól, és számos olyan eszköz is elérhető a piacon, amely mindhárom területen nyújt szolgáltatásoka. A jelen disszertáció fókuszában szereplő tananyagfejlesztés kapcsán, a folyatásban kifejezetten a tervezéshez és a fejlesztéshez kapcsolódó eszközöket vizsgálom. A fejlesztéséhez az alábbi kategóriákba sorolhatók az eszközök a felhasználás szempontjából: 1. Komplex tananyagfejlesztő szoftverek, 2. Tananyagmodul, -elem fejlesztő szoftverek, 3. Fejlesztési folyamatot támogató szoftverek.

A komplex tananyagfejlesztő szoftverek közé azokat az alkalmazásokat sorolom, amelyek segítségével szabványos, teljes értékü, önmagukban értelmezhető e-learning tananyagok készíthetők. Tananyagmodul vagy -elem fejlesztö szoftvernek tekintek minden olyan eszközt, megoldást, amely segítségével valamilyen tudás reprezentálható, és beépíthető pl. a tananyagfejlesztő eszközök segítségével egy elearning tananyagba. E szoftverek nem kizárólagosan, de sok esetben tananyag tartalom fejlesztésére (is) szánja készítője. Ilyen szoftverek pl. az animáció (pl.Vyond ${ }^{16}$ ), kvízek (pl. GoConqr ${ }^{17}$ ), előadások (pl. Prezi ${ }^{18}$ ), képernyőkép készítő (pl. Camtasia Studio ${ }^{19}$ ), videóvágó (pl. Adobe Premier Pro $^{20}$ ) és szoftverszimulációt rögzítő alkalmazások is. A fejlesztési folyamatot támogató szoftverek listája még talán bővebb is lehet, hiszen ahogy a korábbi fejezetekből látható egy igen összetett és sok résztvevős folyamatról van szó. Így ebbe a kategóriába épp úgy beletartozhatnak a drótváz tervező (pl. MockPlus ${ }^{21}$ ), folyamattervező (pl. Microsoft Visio ${ }^{22}$ ),

\footnotetext{
${ }^{16} \mathrm{https}: / / \mathrm{www} . v y o n d . c o m /$

${ }^{17} \mathrm{https}: / /$ www.goconqr.com/

18 https://prezi.com/

${ }^{19} \mathrm{https}: / /$ www.techsmith.com/video-editor.html

${ }^{20} \mathrm{https}: / / \mathrm{www}$. adobe.com/hu/products/premiere.html

${ }^{21} \mathrm{https} / / / \mathrm{www} . \mathrm{mockplus.com/}$

${ }^{22}$ https://products.office.com/hu-HU/Visio/
} 
projektmenedzsment eszközök (pl. Microsoft Project ${ }^{23}$ ), mint a kommunikációt (pl. Slack $^{24}$ ), tesztelést vagy kollaborációt (pl. Google Docs ${ }^{25}$ ) elősegítő megoldások stb. Jelen disszertációban, a terjedelmi korlátok és az e-learning tananyagfejlesztési fókusz kapcsán, a komplex e-learning fejlesztő eszközökre koncentrálok.

A fenti négy lépcsőből álló kiválasztási rendszer részletes leírása a mellékletben (6.10 fejezet) található. További terjedelmi korlátok miatt nem végzem el akár több száz lehetséges eszköz részletes bemutatást, de többek között Don McIntosh (2018) elearning szállítói gyüjtése áttekintését követően is jól látható, hogy tágabban értelmezve akár több száz, de még szüken értelmezve is több tucat e-learningfejlesztö szoftver létezik.

\subsection{Projektek összefoglalása és értékelése - az e-learning ökoszisztéma tükrében}

A fentiekben röviden (a melléklet 6.1 fejezetében pedig részletesen) bemutattam az egyes projekteket. A projektekkel kapcsolatos információk, adatok elemzése során a szisztematikus gyüjtést és feldolgozást - a DSR módszertannak is megfelelően - több nézőpont, és több forrás alapján készítettem, amelybe beletartoznak egyfelől az AR szemlélet mentén a projektek megfigyelése a kutató aktív közremüködése mellett, másfelől szakértői mélyinterjúk és az egyik projekt esetében szövegbányászati kutatás is. Jelen fejezetben e projekteket helyezem el az e-learning tananyagfejlesztés ökoszisztémája szerinti megállapítások mellett, táblázatos formába rendezve. A vizsgálatokat a szövegbányászati kutatási elem bemutatásával kezdem, amelyet egy szakértő támogatásával végeztem el. Ezt követően összefoglalom a projekteket, a kutatások és mélyinterjúk eredményei alapján pedig bemutatom a tananyagfejlesztés közvetlen és közvetett hatásait.

\subsubsection{Területspecifikus alap- és termékismeretek e-learning tananyag visszajelzéseinek vizsgálata - szövegbányászati kutatási elem}

A kutatáshoz egyik partnerünk LMS rendszerében, kizárólag online formában elérhető képzéséhez kapcsolódó, 1114 visszajelzést tartalmazó kérdőív visszajelzéseit

\footnotetext{
${ }^{23} \mathrm{https} / / /$ products.office.com/hu-hu/project/

${ }^{24}$ https://slack.com/

${ }^{25} \mathrm{https}: / /$ www.google.hu/intl/hu/docs/about/
} 
használtam fel. A kérdőív egy 1-8-ig terjedő likert-típusú skálán mérte fel a tananyaggal kapcsolatos specifikus (pl. grafikára, videókra stb.) és általános visszajelzéseket. Emellett két kérdés szöveges válaszadási lehetőséget is adott a tanulóktól: technikai problémák kifejtése, általános visszajelzés.

A vizsgálódáshoz szükséges volt a rendszerben nem egységesen kezelt kérdőívek összefésülésére, továbbá az esetleges demográfiai következtetésekhez - a személyes adatoktól szigorúan megtisztított - az adatbázisok összerendezésére. A rendelkezésre álló adatbázis, a kitöltők számát tekintve, nagy számosságúnak tekinthető a területen, ezért is választottam a szövegbányászati eljárást, mint elemzési formát. Ilyen mennyiségü visszajelzés átolvasása rendkívül időigényes feladat, azonban a kialakításra kerülő modell segítségével kiválaszthatók azok a visszajelzések, amelyek megismerése már elégséges a hatások elemzéséhez. Az elemzések tervezése során látható volt azonban, hogy szövegbányászati szempontból, a rendelkezésre álló visszajelzés mennyisége a határán mozog az elégséges mennyiségnek. Az adatokat áttekintve az alábbi kutatási kérdések merültek fel:

1. Kimutatható-e szignifikáns összefüggés az egyes résztvevők különböző területeket érintő (pl. kinézet és sebesség) értékelései között? Építhető-e stabil modell a pontozás figyelembe vételével?

2. Készíthető-e olyan modell egy e-learning tananyagértékelő kérdőív esetében, amely megbízható értékelést, kategorizálást nyújt, kizárólag a szöveges értékelések alapján? (Mely alapján elvégezhető a következő kérdés kiértékelése.)

3. Milyen hatások és vélemények ismerhetők meg a szöveges visszajelzések alapján?

A kutatásomat a szövegbányászati és gépi tanulási algoritmusok ${ }^{26}$ megírásával Schnellbach Máté adattudós támogatta.

Az elemzést nehezítette, hogy alapvetően a bemeneti adatokat gyüjtő kérdőív minőségbiztosítási célból készült, nem pedig kutatási célból (pl. a demográfiai adatok gyüjtésére nem fektettek hangsúlyt a gyüjtés során).

\footnotetext{
${ }^{26}$ A kapcsolódó notebook elérhetősége: https://drive.google.com/file/d/1AEKw_eooxIAY9DsrYxfMaAhRXOKrsiLL/view
} 
A szövegbányászati elemzés a Google Colaboratory ${ }^{27}$ (Colab) eszközével készült. Elerning területéröl nem találtam ezt az eszközt alkalmazó kutatást. A Colab a Google egy ingyenes, komoly számítási kapacitás mellett, gépi tanulást nyújtó felhőszolgáltatása, amely segítségével mélytanulási algoritmusok és elemzések futtathatók. A nyílt forráskódú Jupyter projektre épülő Colab böngészőben futtattható, a Phyton nyelvet támogatja. Teljesítményének értékelése alapján (Carneiro et al., 2018) messze alkalmas eszköz jelen kutatás lefolytatásához. A vizsgálatok felhőben történtő futtatása lehetőséget kínál a megosztásra, illetve a későbbi - hasonló adatbázisok - gyors betöltésére, azonnali vizsgálatára.

Az elemzés az adatok további tisztításával és szürésével folytatódott, majd a különböző értékelési szempontokat vizsgálata következett. Ezekböl kiderül, hogy a demográfiai adatok igen hiányosan voltak kitöltve, csak a születési dátum állt rendelkezésre további elemzésre alkalmas mennyiségben. A 20. ábrán látható módon, a Colab-ban vizuálisan is jól követhető az egyes változók közötti összefüggések. Kétkét változó közötti összefüggés vizuális reprezentációja az alábbi:

\footnotetext{
${ }^{27}$ https://colab.research.google.com/
} 

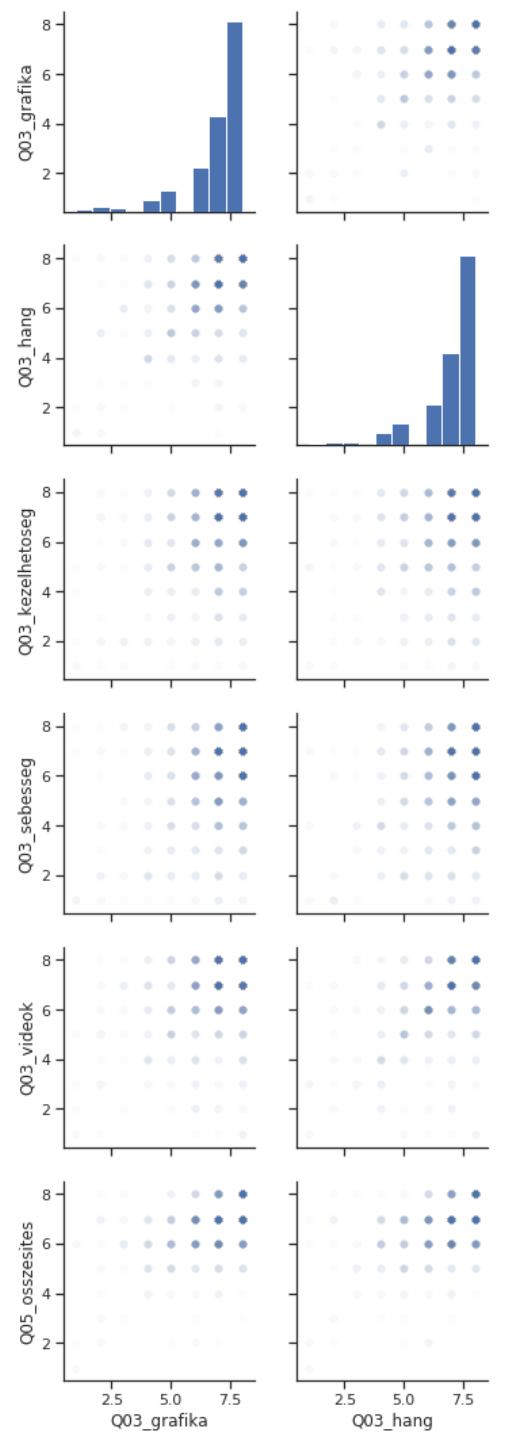

20. ábra - Értékelö kérdőiv pontdiagram (saját ábra 2019)
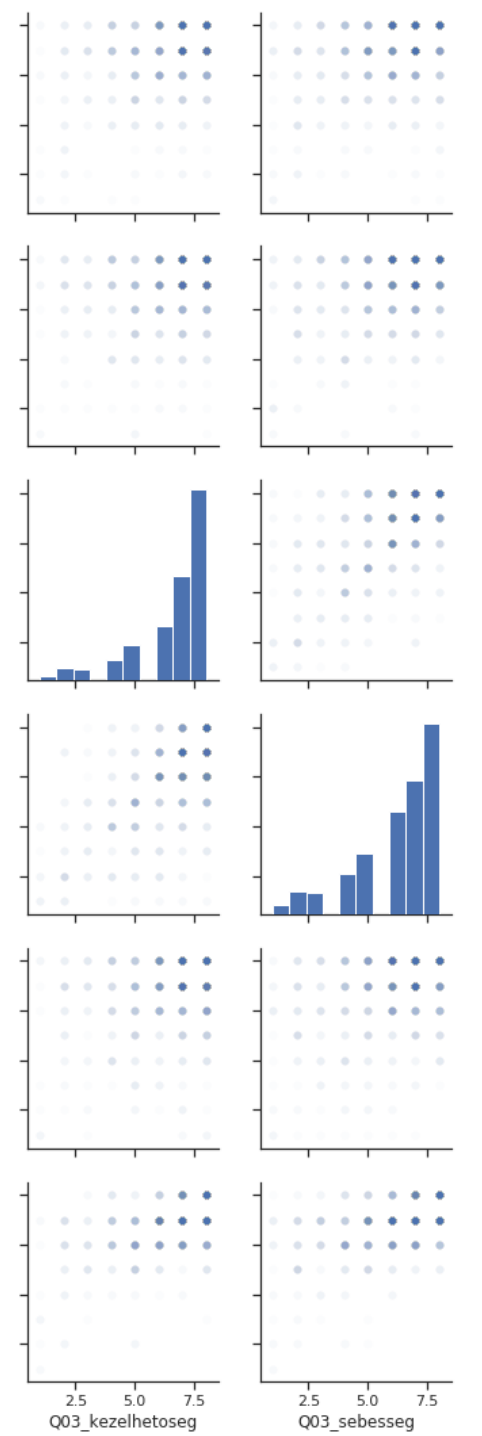
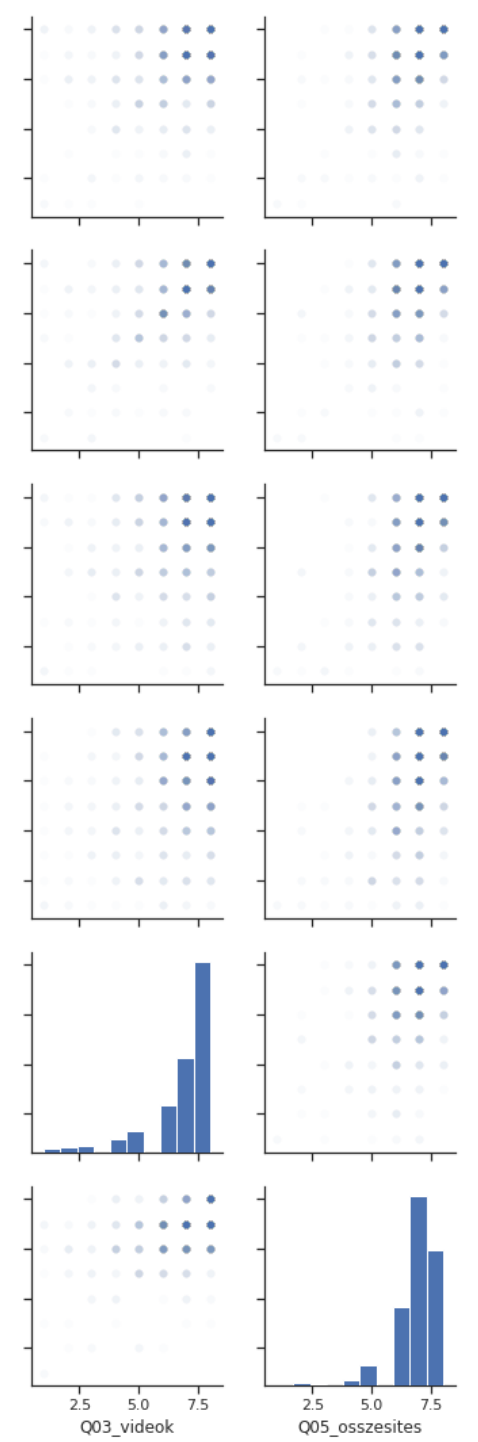

A változó felvett értékeinek gyakoriságát, az átlóban látható hisztogramját jelöli. A modell építéséhez szükséges megvizsgálni a változók közötti korrelációt. Ahhoz, hogy egy logisztikus regresszión alapuló, és stabil modellt tudjuk építeni, fontos, hogy kiszürjük az egymással korreláló változókat. Multikollinearitás vizsgálatával kiderült, hogy az értékelési párok között korreláció nem volt kimutatható. A fentiek alapján az első kérdésre a válasz: nincs két változó között korreláció és olyan eset sincs, ahol több változó alapján megjósolható egy harmadik. Ezek alapján a folytatásban lehetőségünk van egy stabil modell építésére.

Jellemző volt, hogy a tanulók legtöbbször maximális pontszámokat adtak, illetve nem tudták „kihasználni” a skála 8 pontját. Az adatok kategorikussá tételét (binelést) követően kialakultak az egyenletes gyakoriságú kategóriák az egyes változók esetében 
(jellemzően két kategóriába sorolva a visszajelzéseket). „Az ilyen módon transzformált értékek annyiban is megbízhatóbbak, hogy egy 8 fokozatú skála egyes fokozatait egymástól független személyek nagy valószínűséggel egymástól lényegesen eltérően használják, így a 8 fokozatú skála [...] méréselméleti szempontból illúzió csupán.” (Schnellbach, 2019) A pontszámos visszajelzések mellett szöveges válaszokat is megadtak a tanulók. A mélyebb elemzéshez ezeknek a tisztítására volt szükség: kisbetüssé alakítás, speciális karakterek törlése, szótövezés. Ez utóbbi esetében két eljárás ismert: általános (stemming) és lemmatizáló (lemmatization). Míg előbbi nem veszi figyelembe a lexikológiai elvárásokat, addig utóbbi kifejezetten a szótárírói elvárások szerint dolgozik (Endrédy és Novák, 2015). A szógyakoriság vizsgálathoz szükséges volt eltávolítani továbbá a jelentést nem hordozó szavakat (ún. stopwords).

\begin{tabular}{llc} 
Ssz. & Modell elnevezés & AUC érték \\
M1 & Szóelöfordulási mátrix & 0,669 \\
M2 & Szógyakoriság & 0,657 \\
M3 & Relatív szógyakoriság & $\mathbf{0 , 6 7 1}$ \\
M4 & Szópárok & 0,661 \\
M5 & Szótövezés & 0,645 \\
\hline
\end{tabular}

16. táblázat - Alkalmazott regressziós modellek és kapcsolódó (saját táblázat 2019)

Ahogy a 16. táblázatban összefoglaltakból látható, a megfelelő modell megtalálása folyamatos kísérletezésből áll. Tökéletes modellnek (vagyis amely minden esetben jól osztályoz a szöveg elemzése alapján) az ún. igazi pozitív aránya (IPA) 1-gyel, míg az ún. hamis pozitív aránya (HPA) 0 -val egyenlő. Ezt az arányt mutatja be az ún. Receiver Operating Characteristic (ROC) görbe. Ha az algoritmus véletlenszerüen osztályoz, akkor a ROC a fóátló mentén vesz fel értéket. A görbe alatti terület (Area Under the Receiver Operator Curve - AUC) egyszerü mutatószáma annak, hogy összehasonlítsunk modelleket: 0,5 értéknél véletlenszerűen találgat a modell, míg minél közelebbi értéket kapunk az 1-hez, annál pontosabb az osztályzás (Tan et al., 2011).

A legeredményesebbnek tekinthető modell egy olyan logisztikus regressziós modell volt, amely relatív szógyakorisággal vizsgálta az adatokat. Ugyan a modellezési eljárás nem bizonyult teljesen véletlenszerünek, de további forrásadatokra (a szakértői becslés 
szerint kétszer ennyire) lenne szükség a pontosabb, és már valós helyzetben is müködő modell tanításához.

Az elemzés egy könnyen interpretálható logisztikus regressziós modellt alkalmazva, indult, amelyben a szóelőfordulási-mátrix és az általános elégedettséget vizsgáló kérdés (Q05) összevetésének vizsgálata adta a modell alapját. E modell 0,669-as AUC értéket mutatott, amely a legalacsonyabb érték volt a futtatások között, ám ha az osztályzásokat külön megvizsgáljuk, akkor a negatív kategóriába sorolt vélemények esetében nagyon rosszul becsült a modell. A szóelőfordulás helyett a következőkben a szógyakoriság vizsgálata következett, amely javított a modellen, de a tökéletestől távoli eredményt (AUC: 0,657) adott. A további pontosítás érdekében a relatív szógyakoriság módszere következett, amely az ún. term frequency-inverse document frequency (tf-idf) módszerrel volt megvalósítható. Az eljárás lényege, hogy nem csak a szó gyakorisága számít, hanem egy nagyobb adatbázishoz viszonyítva vizsgálandó a gyakoriság (Ramos, 2003). Ez a módszer tovább pontosította a modellt: 0,671-es AUC értékre. A folytatást a szópárok jelentették, előrelépést nem mutatott a modell (AUC: 0,661). Következő lépést jelentett a fent ismertetett szótövezési eljárás (stemming) során kialakított vizsgálat, amely 0,645-es AUC-os eredményt hozott.

Két következtetésre lehet jutni a vizsgálat alapján, amelyeket Schnellbach Máté (2019) is kiemelt:

1. A jelenlegi (legjobb) modell ,éles” környezetben nem alkalmazható, hiszen a 0,6-0,7 közötti AUC értékek nem számítanak kielégítőnek.

2. Az alacsony visszajelzés szám ellenére, mivel az eredmények tartósan jobbak voltak, mint a 0.5-ös AUC érték, így nagyobb esetszám mellett - a fentiekben bemutatott módszertan alkalmazásával - kialakítható egy pontos modell a tananyagok értékelésével kapcsolatosan is.

Fontos lehatárolása a fenti vizsgálódásnak, hogy a Q04-es kérdés alapján valósult meg, és nem az általánosabb Q06-os mentén, mert úgy szignifikánsan rosszabb eredményeket adtak az alkalmazott modellek. Vélhetően a rövidebb, a betanuláshoz nem elegendő hosszúságú szöveges visszajelzések, és az alacsony elemszám miatt adtak rosszabb eredményt az utóbbi adatok vizsgálata során.

További érdekesség, hogy a logisztikus regressziós modell mellett egy ún. gradient boosting modell is futtatásra került, amely lényege, hogy betanuló adaton az 
algoritmus egymást követően végzi az osztályzást és a súlyozott, többségi eredmények alapján határozza meg a kategóriát, mely eljárás igen komoly teljesítménynövekedéssel jár (Friedman et al., 2000). Azonban jelen kutatás alacsony esetszáma miatt, a fenti adatsoron az ilyen típusú modell megbízhatósága nem volt kielégítő. Összefoglalva a kutatás második kérdésére a válasz, hogy lehetséges tanuló modellt kialakítani tananyagok értékelésével kapcsolatosan is, azonban csak több ezres mintán.

A visszajelzések vizsgálatához egyfelől további adattisztítás következett: kikerültek az adatok közül a nagyon rövid visszajelzések (Sok esetben pl. a „Nem volt probléma.” típusú visszajelzések, amelyek ugyan jó visszajelzések az értékelés kapcsán, de közvetett vagy közvetlen hatásokról kevés információt adnak.). Másfelől pedig a fenti relatív szógyakoriságot figyelembe vevő modell vizsgálta meg minden szöveges visszajelzést (nem csak a tanuló-adatokat), és ezek alapján került kiválasztásra a 2020 visszajelzés, amelyek a „legjobb” és „legrosszabb” visszajelzéseket jelentették. Ezekhez került még hozzá a leghosszabb 16 visszajelzés, pontszámtól függetlenül. Ezek értelmezését már nem a tanuló algoritmus végezte el, azonban a több mint 1100 visszajelzés helyett összességében kicsit több mint 50 szöveg visszajelzés alapján kereshetők a hatások.

A tanulók motivációjának megértéséhez, és a visszajelzések értelmezéséhez fontosnak tartom megemlíteni az önmeghatározás-elméletet (self-determination theory, SDT), amely három alapvető szükségletre alapoz: 1. autonómia (autonomy), 2. kapcsolódás/kötődés (relatedness) és 3. kompetencia (competence) (Ryan és Deci, 2000).

\footnotetext{
Szükséglet Tananyagba építhető lehetőségek

autonómia rugalmas határidők, rugalmas formátumok, opcionális elemek, többszöri nekifutási lehetőségek, egyéni tanulási útvonalak, tananyag tartalmak indokoltak

kapcsolódás egyéni tanulási útvonalak, kommunikációs lehetőségek, verseny saját magával, együttmüködési lehetőség a többi tanulóval, csapat feladatok, folyamatos visszajelzés és értékelés, tanulói visszajelzési lehetőség

kompetencia feladatok és tananyag szétbontása kisebb részekre, (kis) hibázási lehetőségek, minden tanulási teljesítmény ,pontot” ér, folyamatos visszajelzés és értékelés, optimális nehézségü feladatok

17. táblázat - Belső motiváció és a tanulási környezet (Aguilar et al., 2015; Niemiec és Ryan, 2009) alapján (saját táblázat 2019)
} 
Az autonómia igénye a szabad, saját elhatározások követésének szükséglete, amely külső tényezőktől mentes. A kapcsolódás szükséglete a másokkal való együttmüködés és mások támogatásának igénye. A kompetencia szükséglete alapján a tanuló számára fontos, hogy értse és befolyásolni tudja a tanulás eredményét, és lehetőséget kell adjon az eredményes tanulásra (Pólya és Martos, 2012). Az SDT elveit a tanulás világába a játékosítási elméleteken túlmutatóan az ún. gameful pedagógia mentén ismerhetjük meg. „A Gameful tervezés azt jelenti, hogy olyan tanulási környezetet tervezünk, amely belsőleg motiváló [a tanuló számára]. Szórakoztató használni, olyan technikák alkalmazásával, amelyeket a játék tervezők használnak, hogy a játékosok elmélyüljenek és elkötelezettek legyenek. Amikor a [videó]játékok a valódi világot modellezik, a tanulási környezeteknek a [videó]játékokat szükséges utánozni, hogy növelje a tanulási motivációt." (Dichev et al., 2015, p.98) Fontos, hogy a gameful tervezés célja nem az, hogy játékokat alakítson ki, de nem is a szórakoztatás a célja. A jó (videó)játékok ugyanis jó tanulási környezetek, hiszen pont akkora kihívásokkal szembesítik a játékosokat, amelyek még éppen kihívást jelentenek, de nem veszik el a kedvüket, folyamatos visszajelzést adnak, és magától értetődően tanítja meg magát a játékot használni. Továbbá az online, közösségi játékok pedig fontos belső motivációt jelentenek a közösséghez tartozás, és a közös kihívások teljesítése révén.

Érdekes volt áttekinteni a visszajelzéseket, mert többségük egyértelműen az SDT által leírt három alapvető pszichológia szükséglet és belső motivációs tényezőre reflektált. A szövegek áttekintése alapján látható, hogy a klasszikus e-learning előnyök (lásd 2.1 fejezet) egyértelműen a tanulást támogatták.

Az autonómia szükséglet kapcsán megemlítendő visszajelzés, hogy a szabad időbeosztás és az ismétlés lehetősége fontos a tanulóknak, és erre lehetőséget adott a tananyag. Azonban sérült az autonómia a visszajelzések alapján a tananyagok kötött sorrendje miatt, és a pontos hátralévő idő ismeretének hiánya okán. A kapcsolódás szükséglete szempontjából fontos volt, hogy ha kértek, akkor gyors és hatékony segítséget kaptak, valamint „tanulási élményként” reflektáltak a kurzusra. Sokszor felmerült a letölthető tartalom hiánya, szükségessége, amely a különböző tanulási stílusokra vezethető vissza. A kapcsolódás szükséglete tetten érhető volt, hogy többen hiányolták a blended megoldások emberi oldalát. Továbbá megfogalmazásra került az azonnali vagy gyorsabb (emberi) visszajelzés hiánya is. A kompetencia szükséglet kapcsán megfigyelhető volt a válaszok között, hogy többen jelezték, hogy olyan 
kérdések is szerepelnek a vizsgában, amelyek nem voltak az tananyagokban. Valamint sok túl hosszú, nagy mennyiségü anyag és túl hosszú vizsga zárta a tanulást. A legsarkosabb megjegyzés még a bemutatott termékek hasznosságát is megkérdőjelezte.

A visszajelzések elolvasását követően elmondható, hogy a negatív megfigyeléseket a technikai problémák (sávszélesség gondok stb.) domináltál, míg a pozitív oldalon jellemzően tetszett a tananyag a tanulóknak elsősorban frissessége és modern tartalmak (videók, játékos feladatok) kapcsán.

\subsubsection{Projektek összefoglalás - szintetizálás és összekapcsolás}

Az alábbi táblázatban összefoglaltam a projektekkel kapcsolatos kvantitatív méröszámokat, amelyek jellemzik az adott fejlesztést.

Ssz. Fejlesztés megnevezése

1. Irodai programokhoz tananyagok fejlesztése

2. Jogszabályok és szervezetek ismertetése

3. Továbbképzési rendszer

4. Közszféra szervezete számára szakmai tananyagok

5. Területspecifikus alap- és termékismeretek

6. Készségfejlesztő tananyagok

Összesen

18. táblázat - A kutatásba bevont fejlesztések összefoglaló táblázata (saját táblázat 2019

$\begin{array}{clc}\text { Tananyagok } & \text { Tanulók }^{28} & \mathbf{I}^{29} . \\ 65+ & \text { Több ezer fö } & 1 \\ 10+ & \text { Több ezer fö } & 1 \\ 100+ & \text { Több tízezer } & 2 \\ & \text { fö } & \end{array}$

Több ezer fö -

Több száz fö

Több száz fö 1

Több, mint

100.000 fó

A 18. táblázat alapján látható, hogy a projektek nagy szervezetek, nagyszámú felhasználói számára készítettek tananyagokat. Mindegyik fejlesztés esetében megfigyelhető volt, hogy nagyon heterogén célközönségnek készültek a tananyagok úgy nem, életkor, mind végzettség, vagy éppen informatikai ismeretek tükrében.

\footnotetext{
${ }^{28}$ Becslés

${ }^{29}$ Kapcsolódó interjúalanyok száma
} 
A 2.2 fejezetben azonosított kapcsolódó társterületek érintettsége az egyes projektek esetében jól magyaráz számos megfigyelést. Éppen ezért az alábbiakban e területek kapcsolódását az alábbi, 19. táblázatban mutatom be.

\begin{tabular}{|c|c|c|c|c|c|}
\hline Ssz. & $\begin{array}{l}\text { Fejlesztés } \\
\text { megnevezése }\end{array}$ & Folyamat $^{30}$ & Termék ${ }^{31}$ & Résztvevö $^{32}$ & Eszköz \\
\hline 1. & $\begin{array}{l}\text { Irodai programokhoz } \\
\text { tananyagok fejlesztése }\end{array}$ & AGY & SZSZ & $\begin{array}{l}\text { tananyag- } \\
\text { szerkesztő }\end{array}$ & $\begin{array}{l}\text { Adobe } \\
\text { Captivate, } \\
\text { HTML }\end{array}$ \\
\hline 2. & $\begin{array}{l}\text { Jogszabályok és } \\
\text { szervezetek ismertetése }\end{array}$ & $\mathrm{KT}, \mathrm{AGY}$ & IMT & gyártásvezető & HTML \\
\hline 3. & Továbbképzési rendszer & $\begin{array}{l}\text { MF, MFH, } \\
\text { KT, AGY, ME }\end{array}$ & $\begin{array}{l}\text { IMT, } \\
\text { THSZ }\end{array}$ & $\begin{array}{l}\text { projektvezető, } \\
\text { gyártásvezető }\end{array}$ & $\begin{array}{l}\text { HTML5, } \\
\text { egyedi } \\
\text { automata }\end{array}$ \\
\hline 4. & $\begin{array}{l}\text { Közszféra szervezete } \\
\text { számára szakmai } \\
\text { tananyagok }\end{array}$ & $\mathrm{KT}, \mathrm{AGY}$ & IMT & $\begin{array}{l}\text { projektvezető, e- } \\
\text { learning szakértő }\end{array}$ & $\begin{array}{l}\text { Articulate } \\
\text { Storyline }\end{array}$ \\
\hline 5. & $\begin{array}{l}\text { Területspecifikus alap- } \\
\text { és termékismeretek }\end{array}$ & $\begin{array}{l}\text { MF, MFH, } \\
\text { KT, AGY }\end{array}$ & IMT & $\begin{array}{l}\text { e-learning } \\
\text { szakértő, } \\
\text { projektvezető }\end{array}$ & $\begin{array}{l}\text { Articulate } \\
\text { Storyline }\end{array}$ \\
\hline 6. & $\begin{array}{l}\text { Készségfejlesztő } \\
\text { tananyagok }\end{array}$ & $\begin{array}{l}\text { MF, MFH, } \\
\text { KT, AGY, ME }\end{array}$ & IMT & $\begin{array}{l}\text { e-learning } \\
\text { szakértő, } \\
\text { projektvezető }\end{array}$ & $\begin{array}{l}\text { Articulate } \\
\text { Storyline }\end{array}$ \\
\hline
\end{tabular}

19. táblázat - Projektek összefoglalása a megoldás konstruálása tükrében (saját táblázat 2019)

A projektek összefoglalásából már látható, hogy az e-learning tananyagfejlesztés folyamatának főbb mérföldkövei már az időrendben első kutatásba bevont projektek esetében is adottak voltak: pl. forrásanyag feldolgozása, gyártás, észrevételezés. Egyfelől ezek a mérföldkövek egészültek ki az évek során a folyamatos visszacsatolások, és a ciklikus tervezési és kutatási folyamatoknak köszönhetően új, lényeges pontokkal. Másfelöl pedig az e mérföldkövek eléréséhez vezető utak, az adott

\footnotetext{
30 megismerés, feltárás (MF); megértés, földre hozás (MFH); kitalálás, tervezés (KT); alkalmazás, gyártás (AGY); mérés, előkészítés (ME).

31 szoftverszimuláció (SZSZ); interaktív és multimédiás tananyag (IMT); történetalapú helyzetszimuláció THSZ

${ }^{32}$ kulcsrésztvevő
} 
szakaszon belüli folyamatok módosítása, kiegészítése, standardizálása, magas szintü dokumentáltsága segítette kialakítani az 5C folyamatot. E mellett az is érzékletes fejlődési folyamat, ahogy a kulcsrésztvevői kör áttevődik a komplex, kreatív szakemberek irányába, de fontos, hogy a teljes folyamat őre, a projektvezetői szerep is kulcsszerep marad. Az alkalmazott eszközök tekintetében az (a termékek tükrében) az IMT tananyagok legjobb eszköze vált egyeduralkodóvá a legutóbbi fejlesztések tekintetében.

\begin{tabular}{|c|c|c|c|c|c|}
\hline Ssz. & $\begin{array}{l}\text { Fejlesztés } \\
\text { megnevezése }\end{array}$ & $\begin{array}{l}\text { PM } \\
\text { modell }\end{array}$ & $\begin{array}{l}\text { Módszertani } \\
\text { megközelítés }\end{array}$ & $\begin{array}{l}\text { Technológiai } \\
\text { háttér }\end{array}$ & $\begin{array}{l}\text { Tudás- } \\
\text { menedzsment }\end{array}$ \\
\hline 1. & $\begin{array}{l}\text { Irodai } \\
\text { programokhoz } \\
\text { tananyagok } \\
\text { fejlesztése }\end{array}$ & vízesés & $\begin{array}{l}\text { értelmezés, } \\
\text { felhasználás }\end{array}$ & $\begin{array}{l}\text { SCORM } \\
\text { tananyagok } \\
\text { HTML } \\
\text { alapokon }\end{array}$ & $\begin{array}{l}\text { rejtett, egyéni, } \\
\text { környezethez } \\
\text { kapcsolódó, } \\
\text { gyakorlati tudás }\end{array}$ \\
\hline 2. & $\begin{array}{l}\text { Jogszabályok és } \\
\text { szervezetek } \\
\text { ismertetése }\end{array}$ & vízesés & $\begin{array}{l}\text { emlékezés, } \\
\text { felhasználás }\end{array}$ & $\begin{array}{l}\text { SCORM } \\
\text { tananyagok, } \\
\text { HTML alapok } \\
\text { és Flash } \\
\text { animációk }\end{array}$ & $\begin{array}{l}\text { explicit, } \\
\text { kollektív, } \\
\text { kodifikált tudás }\end{array}$ \\
\hline 3. & $\begin{array}{l}\text { Továbbképzési } \\
\text { rendszer }\end{array}$ & prototípus & $\begin{array}{l}\text { emlékezés, } \\
\text { értelmezés, } \\
\text { értékelés, alkotás }\end{array}$ & $\begin{array}{l}\text { HTML5 alapok, } \\
\text { egyedi } \\
\text { videólejátszó }\end{array}$ & $\begin{array}{l}\text { explicit, } \\
\text { kollektív, } \\
\text { kodifikált tudás }\end{array}$ \\
\hline 4. & $\begin{array}{l}\text { Közszféra } \\
\text { szervezete számára } \\
\text { szakmai } \\
\text { tananyagok }\end{array}$ & $\mathrm{v}$-modell & $\begin{array}{l}\text { emlékezés, } \\
\text { elemzés, alkotás }\end{array}$ & $\begin{array}{l}\text { SCORM } \\
\text { tananyagok, } \\
\text { HTML5 alapok }\end{array}$ & $\begin{array}{l}\text { explicit, } \\
\text { kollektív, } \\
\text { kodifikált tudás }\end{array}$ \\
\hline 5. & $\begin{array}{l}\text { Területspecifikus } \\
\text { alap- és } \\
\text { termékismeretek }\end{array}$ & $\begin{array}{l}\text { v-modell } \\
\text { és } \\
\text { prototípus }\end{array}$ & $\begin{array}{l}\text { emlékezés, } \\
\text { értelmezés, } \\
\text { elemzés, } \\
\text { értékelés, alkotás }\end{array}$ & $\begin{array}{l}\text { SCORM } \\
\text { tananyagok, } \\
\text { HTML és Flash } \\
\text { tartalom }\end{array}$ & $\begin{array}{l}\text { rejtett, kollektív, } \\
\text { szervezeti } \\
\text { folyamatokban } \\
\text { rejlő tudás }\end{array}$ \\
\hline 6. & $\begin{array}{l}\text { Készségfejlesztő } \\
\text { tananyagok }\end{array}$ & I\&I & $\begin{array}{l}\text { értelmezés, } \\
\text { elemzés, alkotás }\end{array}$ & $\begin{array}{l}\text { SCORM } \\
\text { tananyagok, } \\
\text { HTML5 } \\
\text { tartalom }\end{array}$ & $\begin{array}{l}\text { rejtett, egyéni, } \\
\text { környezethez } \\
\text { kapcsolódó, } \\
\text { gyakorlati tudás }\end{array}$ \\
\hline
\end{tabular}

\footnotetext{
${ }^{33}$ Az újra gondolt Bloom féle taxonómia (Anderson et al., 2001) szerinti tanítási célokhoz illeszkedés alapján (lásd 3.3.2 fejezet)
} 
A 20. táblázatban összefoglaltam az e-learning ökoszisztéma társterületeinek és a projekteknek a kapcsolatait. Amíg elsősorban fejlesztések projektvezetési modelljei mozgatták elsősorban a tananyagfejlesztési folyamat új modelljének kialakítását, ugyanakkor a módszertani és technológiai eredmények összefoglalása viszont leíró jellegü. A tudásmenedzsment kapcsolódás pedig utat mutat a meglévő vagy esetleges innovációs potenciál vizsgálatához. Jelen disszertáció keretein túlmutatnak ezek részletesebb elemzése, de összefoglalás szintjén fontosnak tartottam a kapcsolatot bemutatni.

\subsubsection{Projektek értékelése - a fejlesztésekkel kapcsolatos közvetlen és közvetett megfigyelések, visszajelzések elemzése}

A problémák feltárását és a megoldás konstruálását követően a DSR kutatás harmadik nagyobb lépéseként következik az értékelés, amely a DSR irányelvek között is kiemelten fontos tényező (lásd 1.5.3 fejezet hét irányelve). Az értékelési szakaszhoz kapcsolódó kutatási kérdés (KK4), eredményeként létrejött tananyagok közvetlen, és esetlegesen azokon túlmutató közvetett hatásokra kérdez rá. A folytatásban e hatásokat veszem számba, elsősorban a szakértői mélyinterjúkra, másodsorban saját megfigyeléseimre, harmadsorban pedig a kifejezetten képernyöre fejlesztett „termékspecifikus” (lásd 3.1.5 fejezet) tananyag tanulói által adott szöveges értékelésekre támaszkodva.

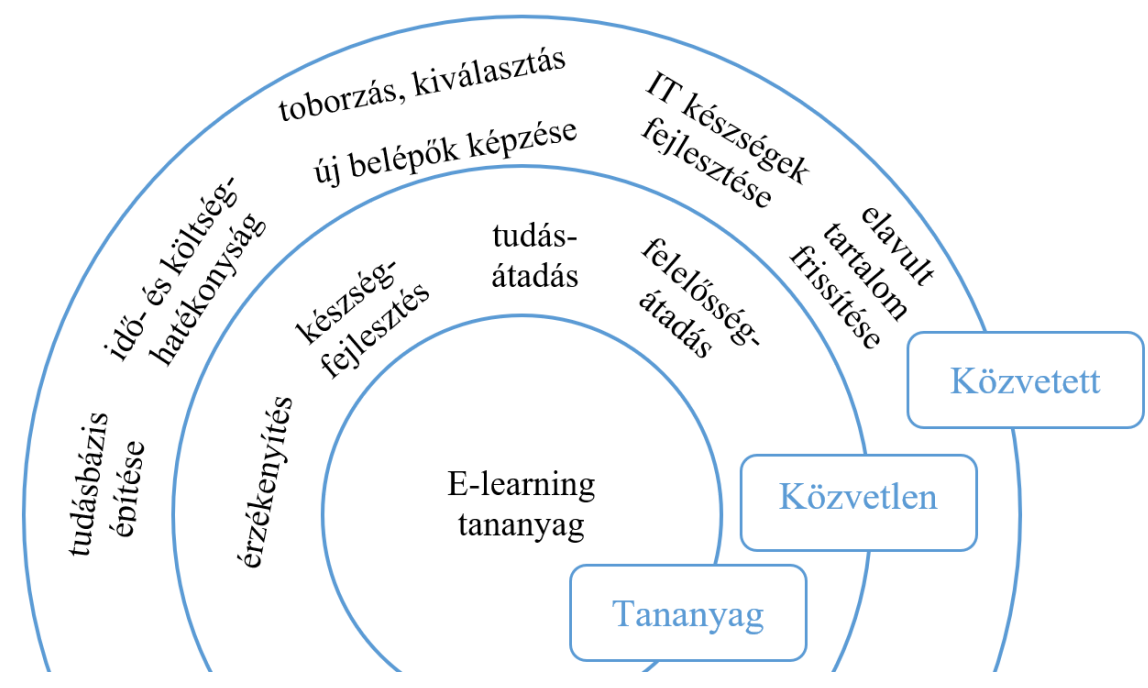

21. ábra-E-learning tananyagfejlesztés hatásai (saját ábra 2019) 


\begin{tabular}{|c|c|c|c|c|}
\hline Ssz. & $\begin{array}{l}\text { Fejlesztés } \\
\text { megnevezése }\end{array}$ & Folyamat $^{34}$ & Közvetlen ${ }^{35}$ & Közvetett \\
\hline 1. & $\begin{array}{l}\text { Irodai } \\
\text { programokhoz } \\
\text { tananyagok } \\
\text { fejlesztése }\end{array}$ & Forgatókönyv & $\begin{array}{l}\text { A részvevő tanulók } \\
\text { megismerték az } \\
\text { Office termékcsalád } \\
\text { eszközeit. }\end{array}$ & $\begin{array}{l}\text { A vállalat számára } \\
\text { kialakításra kerül egy } \\
\text { tudásbázis. Az } \\
\text { alkalmazás magasabb } \\
\text { szintủ használatának } \\
\text { köszönhetően } \\
\text { hatékonyabb a } \\
\text { munkavégzés. (I11.) }\end{array}$ \\
\hline 2. & $\begin{array}{l}\text { Jogszabályok és } \\
\text { szervezetek } \\
\text { ismertetése }\end{array}$ & $\begin{array}{l}\text { Forrásanyag } \\
\text { gyüjtemény, } \\
\text { Forgatókönyv }\end{array}$ & $\begin{array}{l}\text { A tanulók } \\
\text { elsajátíthatták a } \\
\text { szakterületek } \\
\text { specifikus, } \\
\text { jogszabály alapú és } \\
\text { általános (pl. IT } \\
\text { biztonsági) } \\
\text { szakismereteket. }\end{array}$ & $\begin{array}{l}\text { A szervezet egy } \\
\text { visszakereshető } \\
\text { tudásbázist is felépített a } \\
\text { tananyagok } \\
\text { fejlesztésével. Az új } \\
\text { belépők képzése is } \\
\text { egyszerübb lett. }\end{array}$ \\
\hline 3. & $\begin{array}{l}\text { Továbbképzési } \\
\text { rendszer }\end{array}$ & $\begin{array}{l}\text { Tananyagfejlesztési } \\
\text { koncepció, } \\
\text { Forrásanyag } \\
\text { gyűjtemény, } \\
\text { Prototípus(ok), } \\
\text { Forgatókönyv, } \\
\text { Felmérö kutatási } \\
\text { jelentés }\end{array}$ & $\begin{array}{l}\text { A tanulók } \\
\text { megismerhették az } \\
\text { adott szakterület, } \\
\text { sok esetben } \\
\text { jogszabályok } \\
\text { definiálta } \\
\text { ismereteit, továbbá } \\
\text { szemléletformáló } \\
\text { tartalmat is } \\
\text { fogyaszthattak. }\end{array}$ & $\begin{array}{l}\text { A kötelezö képzések } \\
\text { menedzsmentje idö- és } \\
\text { költséghatékonyabbá } \\
\text { vált. Valamint az elavult } \\
\text { oktatási tartalmak } \\
\text { frissítve lettek. }\end{array}$ \\
\hline 4. & $\begin{array}{l}\text { Közszféra } \\
\text { szervezete } \\
\text { számára szakmai } \\
\text { tananyagok }\end{array}$ & $\begin{array}{l}\text { Tananyagfejlesztési } \\
\text { koncepció, } \\
\text { Forrásanyag } \\
\text { gyüjtemény, } \\
\text { Prototípus(ok), } \\
\text { Forgatókönyv }\end{array}$ & $\begin{array}{l}\text { A tanulók } \\
\text { megismerhették az } \\
\text { adott szakterület, } \\
\text { sok esetben } \\
\text { jogszabályok }\end{array}$ & $\begin{array}{l}\text { A kötelező képzések } \\
\text { menedzsmentje idö- és } \\
\text { költséghatékonyabbá } \\
\text { vált. }\end{array}$ \\
\hline
\end{tabular}

\footnotetext{
${ }^{34}$ A fejlesztési folyamathoz kapcsolódó eredménytermékek (lásd 3.3.2 fejezet) felsorolása

${ }^{35}$ Minden esetben az „e-learning tananyagok” is elkészültek természetesen, ezeket külön nem tűntetem fel
} 


\begin{tabular}{|c|c|c|c|c|}
\hline Ssz. & $\begin{array}{l}\text { Fejlesztés } \\
\text { megnevezése }\end{array}$ & Folyamat $^{34}$ & Közvetlen ${ }^{35}$ & Közvetett \\
\hline & & & $\begin{array}{l}\text { definiálta } \\
\text { ismereteit. }\end{array}$ & \\
\hline 5. & $\begin{array}{l}\text { Területspecifikus } \\
\text { alap- és } \\
\text { termékismeretek }\end{array}$ & $\begin{array}{l}\text { Tananyagfejlesztési } \\
\text { koncepció, } \\
\text { Forrásanyag } \\
\text { gyüjtemény, } \\
\text { Prototípus(ok) }\end{array}$ & $\begin{array}{l}\text { A tanulók } \\
\text { megismerhették az } \\
\text { adott termékekhez } \\
\text { és az értékesítési } \\
\text { folyamathoz } \\
\text { kapcsolódó } \\
\text { tudnivalókat, } \\
\text { feladatokat. }\end{array}$ & $\begin{array}{l}\text { A kötelező képzések } \\
\text { menedzsmentje idő- és } \\
\text { költséghatékonyabbá } \\
\text { vált, és megújításra } \\
\text { került a teljes tananyag } \\
\text { szakmai tartalma is. } \\
\text { Továbbá a toborzás és a } \\
\text { kiválasztás is új eszközt } \\
\text { kapott. }\end{array}$ \\
\hline 6. & $\begin{array}{l}\text { Készségfejlesztő } \\
\text { tananyagok }\end{array}$ & $\begin{array}{l}\text { Tananyagfejlesztési } \\
\text { koncepció, } \\
\text { Forrásanyag } \\
\text { gyüjtemény, } \\
\text { Prototípus(ok), } \\
\text { Forgatókönyv }\end{array}$ & $\begin{array}{l}\text { A tanulók puha } \\
\text { készségeket (pl. } \\
\text { kommunikáció, } \\
\text { konfliktuskezelés } \\
\text { stb.) fejleszthetnek. }\end{array}$ & $\begin{array}{l}\text { A puha készségek } \\
\text { fejlesztésének pozitív } \\
\text { hatásai voltak, továbbá } \\
\text { a munkavállalók is } \\
\text { pozitívan értékelik a } \\
\text { képzési lehetőségeket. }\end{array}$ \\
\hline
\end{tabular}

A fejlesztések közvetlen és közvetett hatásait összefoglaló 21. táblázat és 21. ábra alapján megállapítható, hogy az e-learning tananyagfejlesztés közvetlenül a kifejlesztésre került tananyagtartalom tekintetében ad tudást és felelősség-ismeretet, ugyanakkor ha szemléletformáló anyagról vagy puha készségek fejlesztéséről van szó, akkor a közvetlen hatás is ezekhez kapcsolódik. Fontos a közvetett hatások megfigyelése. Általánosan megállapítható, hogy a tananyagok fejlesztésével, és rendszerbe illesztésével kialakul egy visszakereshető, jó esetben a képzési időszakot követően is elérhető tudásbázis, amelyhez a munkatársak vissza-visszatérhetnek. Ez leginkább a SZSZ tananyagok esetében kiemelten fontos, hiszen sok olyan helyzet adódhat - ahogy erre I9. is rámutatott az interjú során - amikor egy-egy funkció használatára (pl. szabadságkivétel) ritkán van egy kollégának szüksége, de a tananyagot visszanézve nem terheli sem felettesét, sem az ügyfélszolgálatokat. Hasonló hatás a jogszabályi ismeretek átadására szolgáló tananyagok esetében is megfigyelhető, hiszen ott is olyan tartalom került feldolgozásra, amelynek összességére nem minden esetben volt szükség készségszinten. Fontosabb volt a 
visszakereshető forma, hogy a részismeretek később is elérhetők legyenek. További általános hatás, hogy a területileg és/vagy időben szétszórt képzések idő- és költséghatékonyabbá válhattak, bár a fejlesztések költségét is figyelembe véve azok évek során térültek meg. Ahol pedig engedélyezték (netán elvárták) a munkaidőn kívüli tanulást, ott pedig a „ki nem eső” munkaidő költségét is érdemes a megtérülési számítások részévé tenni. Ugyancsak megfigyelt hatás, hogy az új belépő munkatársak számára az alapismereteket tartalmazó képzések egyszerübbé, gyorsabbá tették a belépési folyamatot (I7.), amely a toborzásra és a kiválasztásra is hatással lehettek. Olyan szervezetekben, ahol alacsony az IT eszközök használatával kapcsolatos általános tudásszint, ahogy az egyik interjú alanyom (I6.) rámutatott, az e-learninges tananyagok használatával az általános, az IT készségek javulását figyelték meg. A szemléletformáló és puha készségek fejlesztésére kialakított tananyagok esetében pedig - remélhetőleg - magától értetődő a konkrét ismereteken túlmutató hatás, de ezt I6. interjú alanyom meg is erősítette. Jellemző, hogy ebben az esetben is a blended típusú képzések erős hatása emelhető ki. Az ilyen képzés további hatása, amelyet több interjúalanyom (I2., I7.) is említett, hogy pozitív ösztönző a munkatársak számára, akik így szívesebben maradnak. Amennyiben pedig licenszek megszerzéséhez kötött tevékenységet folytat a szervezet, úgy a tananyagtartalom elsajátításának közvetlen hatása lehet az értékesítésre is (I8.).

\subsection{Gyakorlati eredmények összefoglalása - az e-learning by design szemlélet és az e-learning tananyagfejlesztés víziója}

A kutatás gyakorlati eredményeinek bemutatása a DSR fontos eleme (Hevner et al., 2004) (lásd 1.5.1 fejezet), így ennek érdekében itt összefoglalom a dolgozat során már többször megfogalmazásra került „e-learning by design” szemlélet elveit, valamint egy általános víziót az e-learning tananyagfejlesztés ökoszisztémájának vizsgálata alapján.

\subsection{1 „E-learning by design" - szemléletmód az e-learning fejlesztésekhez}

A privacy by design szemlélet (Cavoukian, 2011) logikájára építve, az alábbiakban foglalom össze, hogy mit jelent ha egy tananyagfejlesztési folyamat az e-learning by design elve szerint folyik, ezzel megválaszolva a negyedik kutatási kérdést is (KK4).

1. a teljes képzés vagy tananyag esetében figyelembe vesszük és proaktívan készülünk a képernyő elött való tanulásból fakadó eltérő körülményekre és 
igényekre. Ez egyszerre jelent megváltozott tartalomfogyasztási szokásokat az oktatási tartalom fogyasztása esetében (Guo et al., 2014); ICT eszközök használatával kapcsolatos készségek figyelembevételét (lásd célcsoport elemzés); a tanulás megváltozott fiziológiás körülményeit (Molnár, 2015); és az interperszonális viszonyok megváltozását (pl. egyedül tanulási és csoportos tanulási lehetőségek vizsgálata) (Kuhn, 2015).

2. A fejlesztések azt a nézőpontot tekintik alapvetőnek, hogy a képzések digitális eszközökkel sok különbözö területen támogathatók. Kezdve a különbözö típusú tananyagelemek más és más digitális technológiával történő feldolgozásától, egészen az eltérő tanulási képességek és szokások széleskörü kiszolgálásáig.

3. Már a koncepció kidolgozása során beépüljenek az e-learning megoldások úgy az ICT, mint az oktatás- vagy projektmódszertani területekröl egyaránt. A modern webes technológiák használata mellett, tudatosan alkalmazzunk elearning vagy kevert (blended) oktatásmódszertani elemeket, egy olyan fejlesztési projekt keretében, ahol a különböző területekről érkező szakértők tudása nem egyszerüen összeadódik, hanem szinergia is kialakul. A koncepció korrekt kidolgozása eredményeképpen felmerülhet akár az is, hogy nincs is szükség e-learning támogatásra egy adott képzés kapcsán (I4.).

4. Ebben a szemléletben a jelenléti képzések és az e-learning képzések nem egymás ellenpontjai, hanem a képzések tervezésének pillanatától egymást kiegészítő, erősitő megoldások (akár jelenléti tréningen alkalmazott digitális eszközökröl, akár egy az adminisztrációt segítő rendszerről legyen szó).

5. A tananyagfejlesztés eredményei nem egy szük értelemben vett zárt, egyszeri terméket jelentenek, hanem a képzések teljes életciklusát figyelembevéve kerüljenek megalkotásra (pl. figyelembe vesszük a gyorsan elévülő tartalmakat, a visszakereshetőséget $s t b$.$) .$

6. A fejlesztési folyamat nyitottan és átláthatóan támogassa a széles körből érkező résztvevők igényeit, amely alapján a teljes folyamat jól követhető és dokumentált.

7. Folyamatosan szem előtt tartjuk és a középpontba helyezzük a tanulót és a tanulást, hiszen végeredményként értük, és e folyamat sikeréért vannak a képzések (Cavoukian, 2011). 
8. Szemléletmódjukat tekintve olyan szakembereket alkalmazunk a fejlesztések során, akik számára az e-learning tananyagokkal támogatott, kiegészített tanítási és tanulási helyzetek alapvetőnek számítanak.

9. Olyan eszközöket alkalmazunk, amelyek tervezésük és müködésük szerint elearning megoldások fejlesztésére hivatottak.

\subsubsection{Következtetések és alapvetések - egy e-learning vízió}

A következőkben olyan alapvetéseket kívánok megfogalmazni, amelyek egyfelől a kutatás tapasztalataiból fakadnak, másfelöl pedig olyan meghatározó hozzáállásbéli alapokat jelentenek, amelyek segítik megérteni az e-learning by design, a tanuló- és tartalomközpontú e-learning tananyag és az öt-ciklus folyamat alapjait és kereteit.

1. A tanuláshoz való általános pozitív hozzáállás és a megfelelő szervezeti kultúra nélkül bármilyen, akár tudásmenedzsment alapú, a disszertációban megfogalmazott elvek mentén összeállított képzési rendszer, és a leírt folyamat során kialakított tananyagok is hatás nélkül maradhatnak. Éppen ezért kulcsfontosságú a vezetői elköteleződés a szervezet és az egyének képzése tekintetében.

2. „A tartalom a király.” (Click és Baird, 1974, p.163) írta meg még 1974-ben Click és Baird, de nagy nyilvánosság elött Bill Gates (1996) esszéjét követően lett népszerü. Az akkor még a szárnyait próbálgató internetre gondolva, és 20 év távlatából látjuk, hogy igaza volt. E kitétel helytálló az e-learning esetében is: semmilyen oktatástechnológiai vívmány vagy innováció nem érhet célt a jó tartalom nélkül. Halmozottan igaz ez az e-learning tananyagokra is. Olyan tartalmat szükséges a tanulók elé állítani, amely releváns, befogadható és képernyö elött is értelmezhetö.

3. Ha a tartalom a legfontosabb is, tisztában kell lennünk, hogy hiába a legjobb tartalom, önmagában nem áll meg. Az e-learning világában a tartalom megfelelő értelmezési környezetét legtöbb esetben olyan rendszerek adják, amelyek a tananyagok lejátszása mellett. Ezek az ún. tanulásmenedzsment-rendszerek (Learning management System - LMS) és tanulás- és tartalommenedzsmentrendszerek (Learning Content Management System - LCMS) (Nemeslaki, 2011a). 
4. Alapvetésként fontos kiemelni, hogy a tanuló- és tartalomközpontú tananyagok komplex módon ötvözik és szinergiát jelentenek a technológiai és módszertani elemeket tekintetében. Mindezt olyan megjelenés mellett teszik, amely ösztönzi a tanulókat a részvételben.

5. A tananyagok (egyéni) tanulási környezetekben pedig olyan tanulási és tanítási eszközpark részei lehetnek, amely akár további más szolgáltatásokkal pl. kommunikációs, kollaborációs stb. funkciókkal kiegészítve ún. mashup learning környezet alkothatnak (Auinger et al., 2009), mint ahogy ennek fontosságára mutatott rá az egyik interjúalanyom (I5.).

6. A ,jó”, vagyis tanuló- és tartalomközpontú e-learning tananyagok és e-learninges képzések hármas jellemzője, hogy frissek, vegyesek és kevertek. A frissesség azt jelenti, hogy a teljes tananyagfejlesztési folyamat során figyelemmel vagyunk arra, hogy a tananyagok bizonyos tartalmi elemi időről-időre (gyakrabban vagy ritkábban) felülvizsgálatra, vagy akár teljes cserére szorulnak (pl. jogszabályi környezet változása stb.). Éppen ezért kiemelten fontos, hogy olyan struktúrát és tartalmi elemeket állítsunk össze, amelyek kiállják az idő próbáját: módszertani és technológiai oldalról is frissíthető marad a tananyag.

7. A vegyes tananyagok alkotása azt jelenti, hogy többféle módszertani és technológiai megoldást alkalmazunk az oktatási cél elérése érdekében. Egy jól felépített tananyag esetében ez azért is fontos, mert az eltérő tanulási szokású tanulókat egyaránt ki lehet így szolgálni, másfelöl pedig változatos, hatékonyabb tananyag alakítható ki. Továbbá minden tartalmi elem esetében azonosíthatók azok a módszertanok és technológiák, amelyek a legjobban szolgálják az adott tudás átadását.

8. A kevert (blended) képzéseket egy korábbi fejezetben (lásd 2.1) már definiáltam. Az alapvetések között e megközelítés fontosságára szeretnék hangsúlyt fektetni. Nagyon sok fajtájú és típusú téma feldolgozható digitális eszközök támogatásával, és szinten minden oktatási cél támogatható e-learning tananyagok készítésével. Azonban számos olyan tartalmi elemet, és módszertani megfontolás is figyelembe kell venni az oktatási cél kielégítésekor, amely a tananyagokra, mint eszközként tekint, és aktívan bevonja a képzésekbe az oktatót, trénert, tutort stb.: az adott célhoz legjobban illeszkedő embert. 
Ahogy a disszertáció elején jeleztem (1.2 fejezetben), kutatásaimat nagy szervezetek vonatkozásában végeztem el. Azonban a fent leírt alapvetéseket általános érvényünek tekintem, kisebb szervezetek számára is relevánsak képzések, tananyagok fejlesztése során. 


\section{A KUTATÁS ÉRTÉKELÉSE ÉS A TUdOMÁNYOS EREDMÉNYEK - KÖVETKEZTETÉSEK ÉS KITEKINTÉS}

\subsection{A kutatás értékelése - Design Science szemlélet alapján a kutatásról}

A kutatás értékelését először a feltárt eredmények megoldási területének és a problémák ismertségét vizsgálva a 22. ábrán mutatom be.

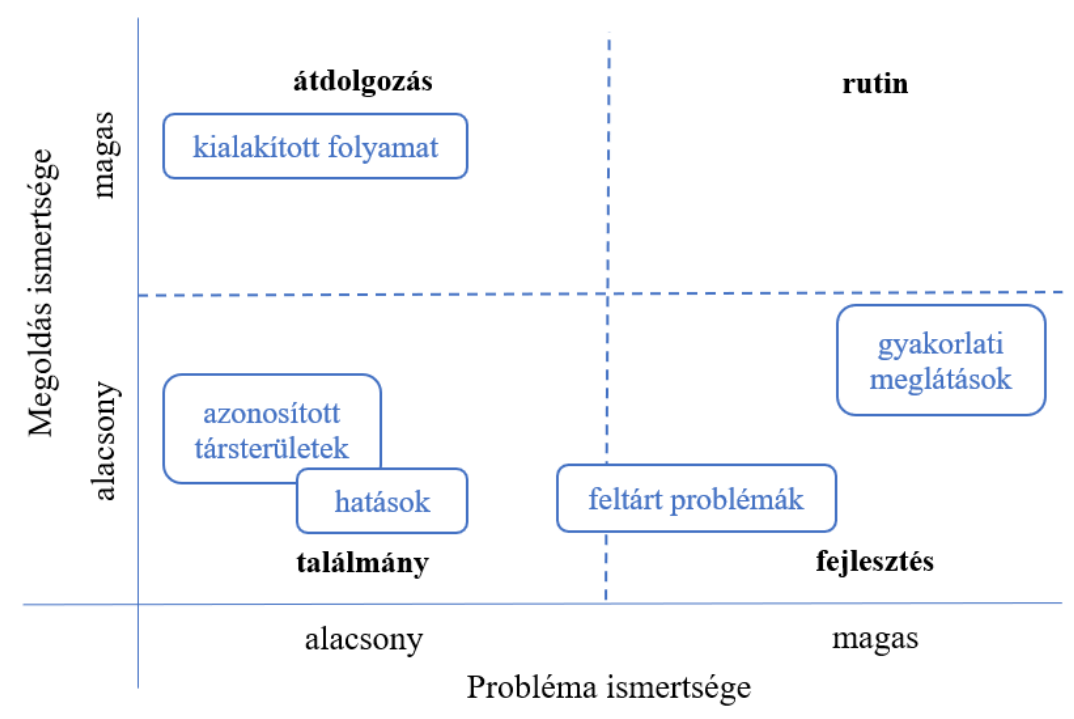

22. ábra - Kutatási eredmények értékelése (Vaishnavi és Kuechler, 2004) alapján (saját ábra 2019)

A Vaishnavi és Kuechler (2004) szerzőpáros által megfogalmazott DSR hozzájárulás alapján (lásd 1.5.3 fejezet), az eredmények az alábbiak szerint kategorizálhatók.

1. Feltárt problémák: a problémák jelentős része már ismert volt a kutatástól függetlenül is, ám az e-learning tananyagfejlesztés szempontú összefoglalása nem volt még ismert, így az eredmény a „fejlesztés” kategóriába esik, hiszen ismert problémák esetében jelent új megközelítést.

2. Azonosított társterületek: az e-learning tananyagfejlesztés szempontjából kevéssé ismert a kapcsolódó társterületek világának elemzése, és nem teljesen ismeretlen, de kevéssé ismert ezek szisztematikus gyüjtése. Ennek megfelelőn tekintek „találmányként” erre az eredményre.

3. Kialakított fejlesztési folyamat, azonosított termékek, résztvevők, eszközök: az „átdolgozás” kategória elsősorban az új, 5C fejlesztési folyamat által határozható meg (a kapcsolódó résztvevőkkel, termékekkel és eszközökkel), 
amely esetében a megoldások ismertsége és számossága igen magas, de a tananyagfejlesztési probléma ismertsége alacsonynak tekinthető.

4. Megismert közvetlen és közvetett hatások: az irodalomfeldolgozás alapján a feltárt problémák, és az ezekre adott e-learning megoldások (még) kevéssé ismertek. Ezek alapján értékeltem „találmányként” ezt az eredményt.

5. Összefoglalt gyakorlati meglátások: a problémák, amelyre megoldást nyújt sok esetben ismertek, de a megoldási tartományban bőven van még hely. Így került a „fejlesztés” kategóriába a gyakorlati meglátások összefoglalása.

Az eredményen túl, magát az egész kutatást értékelve, a Hevner (2004) által lefektetett hét irányelv megvalósulását foglalom össze az alábbi, 22. táblázatban.

Irányelv

1. Tervezés, mint termék

2. Releváns probléma

3. Értékelés

5. Kutatási szigor

6. Tervezés, mint keresési folyamat

7. Kutatás kommunikációja

\section{Disszertáció eredménye}

A kutatás eredménytermékeként feltártam az e-learning tananyagfejlesztés ökoszisztémáját.

Egyfelöl bemutattam az ökoszisztémát ,Az e-learning társterületek azonositása és elemzése - az érintett területek felkutatása és áttekintése" c. fejezetben.

Másfelől pedig a „Megoldás konstruálása - (1.) a tananyagfejlesztési folyamat felépitése, (2.) a termék, (3.) kapcsolódó szerepek és (4.) eszközök bemutatása" c. fejezetekben fókuszáltam magára a tananyagfejlesztésre.

Hat területen, huszonhárom konkrét, releváns üzleti problémákat azonosítottam a „Problémák azonositása a kutatás által megvizsgálni kívánt terület problématérképének felrajzolása" c. fejezetben.

Mélyinterjúk és szövegbányászati módszer alkalmazásával értékeltem a tervezés eredményét a „Projektek összefoglalása és értékelése - az e-learning ökoszisztéma tükrében" c. fejezetben.

A fentiek és a „Design Science - az alapok ismertetés és a disszertációban alkalmazott szempontok kifejtése", az „Akciókutatás és esettanulmány - a disszertáció hátterében „,meghúzódó” kutatásmódszertani startégiáról, szemléletrôl és a miértekről" és a „Háromszögelö vizsgálatok - röviden a dolgozat érvényességével kapcsolatosan" c. fejezetekben bemutatott módszertanok alkalmazása alapján világos és igazolt eredményeknek tekintem a feltártakat, amelyek a szigorú módszertani feltételeket is biztosították.

A kutatás gyakorlati aspektusa nyújtja a környezet törvényszerüségeinek megfelelő figyelembevételéhez.

Az eredmények széleskörü publikálása egy további feladat, amelyhez a disszertáció több ponton is megfelelő alapanyagot nyújthat a fentiekben ismertetett eredmények bemutatására és vitára bocsátása érdekében. 
Összefoglalóan, a hét irányelv szempontjainak megfelel a disszertáció, és a tudományos eredmények tükrében, amelyeket a következő fejezetben mutatok be részletesen, eredményesnek is tekintem a kutatást. A DS kutatás külső értékeléséhez a 6.2 fejezetben található Hevner és Chatterjee (2010) által bemutatott kérdéssor is támpontot adott. Jelen disszertáció keretein túlmutat, de érdemes megemlíteni a DSR kutatásokhoz Venable és szerzőtársai (2016) által kifejlesztett értékelési keretrendszert (Framework for Evaluating Design Science Research - FEDS), amely alapján a későbbiekben gyakorlatba ültethető értékelést lehet érdemes folytatni a disszertáció egyes eredményei tekintetében.

\subsection{A disszertáció tudományos eredményeinek, téziseinek összefoglalása - keretekről és öt pontban az eredményekről}

A disszertáció eredményeinek összefoglalása előtt érdemes megemlíteni azokat a lehatárolásokat, amelyek között a dolgozatban megfogalmazott eredmények érvényesek. Bár a szakirodalom áttekintése során bőven merítettem a nemzetközi tudományos eredményekböl, a kutatás során megvizsgált projektek mind Magyarországon működő szervezetek voltak, még a multinacionális vállalatok esetében is az együttmüködés kiterjedése nem lépett túl az országhatáron. Ehhez hasonlóan a mélyinterjúk alanyai - bár közöttük volt jelentős nemzetközi tapasztattal rendelkező szakértő is - mind hazai környezetben dolgozó kollégák voltak. További lehatárolást jelent, hogy a disszertáció nem vizsgált pénzügyi megtérüléssel vagy kapcsolódó számításokkal összefüggő kérdéseket. A disszertáció az e-learning világon belül is kifejezetten a tananyagfejlesztés kérdéskörét járja körül, és csak érintőlegesen kapcsolódik az e-learning rendszerek (és egyéb eszközök) nélkülözhetetlen elemeihez.

A DSR kutatás eredményeként az alábbiakban összefoglalom a disszertáció elkészítése során kialakított tudományos eredményeket, amelyek választ adnak a kutatási kérdéseimre, illetve alátámasztják az ehhez kapcsolódó hipotéziseket (1.9 fejezet). 
T1: Szövegelemzés és irodalomkutatás során azonosítottam azokat a társterületeket, amelyek lényeges vizsgálati alapját és keretét jelentik az e-learning tananyagfejlesztés ökoszisztémájának. E társterületek pedig a következők: projekt- és szoftverfejlesztésmenedzsment, tananyagfejlesztési pedagógiai és technológiai módszerei, valamint a tudásmenedzsment és a szervezeti innováció tudományos területei.

T2: A kutatás során a részletesen feltárt projektek és a mélyinterjúk eredményei alapján azonosítottam 23 problémát, amelyeket 6 problémakörbe soroltam. E problémák között ún. elvetemült (wicked) problémák is találhatók. Az ökoszisztéma szemlélet alapú tananyagfejlesztés ezek kezelésében segítséget nyújthat.

T3: A megoldás konstruálása során definiáltam az e-learning tananyagfejlesztés ökoszisztémáját az öt-ciklus tananyagfejlesztés folyamatának kialakításával, a kulcsrésztvevők és fejlesztési eszközök azonosításával és elemzésével, valamint a termékek meghatározásával. Ezen eredményeket az akciókutatási kutatási stratégia mentén alakított megfigyelések, interjúk és a szakirodalom feldolgozása alapján támasztottam alá.

T4: A fejlesztési eredmények értékelése során, a mélyinterjúk, a megfigyelések és a szövegbányászati vizsgálat segítségével, feltártam az e-learning tananyagfejlesztéshez kapcsolódóan 4 közvetlen (pl. megvalósult tudásátadás) és 6 közvetett (pl. elavult tartalmak frissítése) hatást. Ezek a hatások (akár) elvetemült problémák kezelésével is összefüggésbe hozhatók.

T5: Az irodalomfeldolgozás, a mélyinterjúk és az empirikus megfigyeléseim alapján összefoglaltam az ún. e-learning by design koncepciót, amelynek lényege, hogy olyan szemléletmódot és gyakorlati meglátásokat, tanácsokat tartalmaz, amelyek biztosítani tudják, hogy az így készült tananyagok megfeleljenek a képernyő előtti tanulás technológiai és módszertani követelményeinek, végső soron pedig az érdekeltek által elvárt tanulási eredményeket nyújtsák.

A disszertációban a társterületek absztrakt vizsgálata felől indulva összefoglaltam a konkrétumokat is meghatározó tanuló- és tartalomközpontú e-learning tananyagok jellemzőit. Továbbá leírtam az általam öt-ciklus tananyagfejlesztés folyamatnak nevezetett tervezési és fejlesztési modellt. A gyakorlati eredményeket pedig a 
szemléletmódot kínáló e-learning by design megközelítésnek a definiálásával foglaltam össze, amely harmonikusan integrálja az e-learning tananyagfejlesztés módszertani és technológiai látásmódjához kapcsolódó gondolatokat.

A lehatárolási feltételek miatt a kutatás nem foglalkozott olyan fontos és további vizsgálatokat elörevetítő kérdésekkel, mint a fenti ökoszisztéma müködésének kiegészítse költségelemzésekkel, és ennek kapcsán megtérülés számítási modellek kialakításával. Kifejezetten érdekes, mélyebben vizsgálatot igénylő munka, hogy az elearning és a tananyagok szerepét megértsük és definiáljuk a szervezeti innovációs folyamatokban. A disszertáció jelen formájában is igen erős gyakorlati nézőpontot fogalmaz meg, azonban az ökoszisztéma egyes részeinek további vizsgálata által, az e-learning tananyagokról mélyebb, a gyakorlatban alkalmazható eredmények is várhatók. Ehhez olyan teljesítmény mutatószámok (KPI) azonosításán át vezethet az út, amelyek konkrét indikátorai lehetnek egy-egy későbbi fejlesztésnek. További kutatási területként azonosítható az öt-ciklus modell jobb és jobb megközelítése érdekében, hogy hogyan müködhet a gyakorlatban egy folyamatosan fejlesztés alatt lévő tananyag, milyen jellemzői vannak ennek az új fejlesztési folyamatnak. Illetve, hogy milyen tanulási eredményeket lehet azonosítani közép- és hosszútávon (pl. 3-6 vagy 12 hónapot követően) (I4.). További kutatások segíthetnek pontosítani az egyes termékek gyártásához kapcsolódó konkrét eljárásrendeket, a legjobb gyakorlatok kialakítását.

Jelen disszertáció egy lépés kíván lenni ahhoz az igen tág diskurzushoz, amely azt vizsgálja, hogy egy IKT alapú fejlesztés, jelen esetben egy e-learning tananyagfejlesztés, hozzájárul-e a szervezetek hatékonyságához, szervesen kapcsolódik-e intézményesített környezetekhez. Ezek mélyebb vizsgálata izgalmas, és bonyolult kihívást jelent. E kutatások célja lehet, hogy szervezetek és vállalatok stratégiájának részévé lehessen tenni a képzési víziót, és a képzési stratégia pedig összhangba kerüljön a vállalat alapvető céljaival, és kialakulhasson a tanulószervezet. 


\section{IRODALOMJEGYZÉK}

Abrahamsson, P., Salo, O., Ronkainen, J., et al. (2002): Agile software development methods. Review and analysis. Espoo: VTT Technical Research Centre of Finland.

Adelman, C. (1993): Kurt Lewin and the Origins of Action Research. Educational Action Research, 1 (1): 7-24. doi:10/dwc8rr.

Adkins, S.S., Parsons, J. és Greer, T. (2017): Metaari’s Learning Technology Research Taxonomy. Research Methodology.

Aguilar, S.J., Holman, C. és Fishman, B.J. (2015): Game-Inspired Design: Empirical Evidence in Support of Gameful Learning Environments. Games and Culture. doi:10/gf6tmj.

Akbari, N. és Ghaffari, A. (2017): Verifying relationship of knowledge management initiatives and the empowerment of human resources. Journal of Knowledge Management, 21 (5).

Allen, M.W. (2016): Michael Allen's Guide to E-Learning: Building Interactive, Fun, and Effective Learning Programs for Any Company. John Wiley \& Sons. (GoogleBooks-ID: 7ibWBgAAQBAJ).

Alonso, F., Lopez, G., Manrique, D., et al. (2005): An instructional model for webbased e-learning education with a blended learning process approach. British Journal of Educational Technology, 36 (2): 217-235. doi:10/c7ddfm.

Aly, D.W.O. (2017): New emerging trends in organizational learning to business enterprises development with special focus on Egypt. Global Journal of Political Science and Administration, 5 (5): 1-16.

Anderson, L.W., Krathwohl, D.R., Airasian, P.W., et al. (2001): A taxonomy for learning, teaching, and assessing: A revision of Bloom's taxonomy of educational objectives, abridged edition. White Plains, NY: Longman.

Andrews, D. (2015): The circular economy, design thinking and education for sustainability. Local Economy: The Journal of the Local Economy Policy Unit, 30 (3): 305-315. doi:10/gfpf8g.

Andriotis, N. (2015): eLearning for Human Resources Management. Elérhetőség: https://www.efrontlearning.com/blog/2015/02/elearning-human-resourcesmanagement.html (Letöltve: 2019.08.13.).

Auinger, A., Ebner, M., Nedbal, D., et al. (2009): "Mixing Content and Endless Collaboration - MashUps: Towards Future Personal Learning Environments." In Stephanidis, C. (ed.): Universal Access in Human-Computer Interaction. Applications and Services. Berlin, Heidelberg: Springer Berlin Heidelberg. pp. 14-23. doi:10.1007/978-3-642-02713-0_2.

Babbie E. (2008): A társadalomtudományi kutatás gyakorlata. Balassi Kiadó. 
Balkányi P. (2015): “Kvíz alapú tanulástámogató mobilalkalmazás fejlesztése.” $\underline{I n}$ Námesztovszki Z. és Vinkó A. (eds.): XXI. Multimédia az oktatásban és II. IKT az oktatásban konferencia kiadvány. Újvidéki Egyetem Magyar Tannyelvü Tanítóképző Kar, Szabadka.

Balkányi, P. és Orbán, Z. (2011): Virtuális információk a fizikai térben: a kiterjesztett valóság jövlHoképe. Információs Társadalom, 11 (1-4): 48-63.

Balkányi P. és Orbán Z. (2012): Aktor alapú társadalom-technológia kapcsolat vizsgálata az e-learning világában. Gazdasági élet és társadalom, (I-II.): 271-287.

Banks, S. (2016): Innovation: Fail Fast or Experiment Quickly? Elérhetőség: https://www.linkedin.com/pulse/innovation-fail-fast-experiment-quickly-simonbanks (Letöltve: 2018.06.22.).

Bartis, E. (2014): Az interpretatív rugalmasság eszközei: az információs rendszeren kívüli felhasználói rutinok. Doktori (PhD): értekezés, Budapesti Corvinus Egyetem. Elérhetőség: http://phd.lib.uni-corvinus.hu/772/ (Letöltve: 2019.03.04.).

Baskerville, R. (2001): "Conducting action research: High risk and high reward in theory and practice." In Qualitative research in IS: Issues and trends. IGI Global. pp. 192-217.

Baskerville, R. és Myers, M.D. (2004): Special Issue on Action Research in Information Systems: Making IS Research Relevant to Practice: Foreword. MIS Quarterly, 28 (3): 329-335. doi:10/gf6crk.

Baskerville, R. és Wood-Harper, A.T. (1998): Diversity in information systems action research methods. European Journal of information systems, 7 (2): 90-107. doi:10.1057/palgrave.ejis.3000298.

Baskerville, R., Wood-Harper, T., Chairman-Kock, N., et al. (1999): "IS action research: can we serve two masters?" In Proceedings of the 20th international conference on information systems. 1999. Association for Information Systems. pp. $582-585$.

Baskerville, R.L. (1997): Distinguishing action research from participative case studies. Journal of systems and information technology, 1 (1): 24-43. doi:10/cfgwrc.

Baskerville, R.L. (1999): Investigating Information Systems with Action Research. Communications of AIS, 2 (19).

Baskerville, R.L. és Wood-Harper, A.T. (1996): A critical perspective on action research as a method for information systems research. Journal of information Technology, 11 (3): 235-246. doi:10.1177/026839629601100305.

Benbasat, I., Goldstein, D.K. és Mead, M. (1987): The Case Research Strategy in Studies of Information Systems. MIS Quarterly, 11 (3): 369-386. doi:10/cwphtn. 
Benbasat, I. és Zmud, R. (2003): The Identity Crisis Within the IS Discipline: Defining and Communicating the Discipline's Core Properties. Management Information Systems Quarterly, 27 (2). doi:10/gf6crs.

Benbasat, I. és Zmud, R.W. (1999): Empirical Research in Information Systems: The Practice of Relevance. MIS Quarterly, 23 (1): 3-16. doi:10/bbqgq9.

Bencsik A. (2014): Miért nem müködik? Tudásmenedzsment, 15 (1): 29-46.

Birkinshaw, J., Bouquet, C. és Barsoux, J.-L. (2010): The 5 Myths of Innovation. MIT Sloan Management Review. Elérhetöség: https://sloanreview.mit.edu/article/the-5myths-of-innovation/ (Letöltve: 2018.06.22.).

Blackburn, G. (2016): In my end is my beginning: Elearning at the Crossroads. doi:10.13140/rg.2.1.5111.4483.

Blass, E. és Davis, A. (2003): Building on solid foundations: establishing criteria for e-learning development. Journal of Further and Higher Education, 27 (3): 227-245. doi:10/bhnth5.

Blichfeldt, B.S. és Andersen, J.R. (2006): Creating a Wider Audience for Action Research: Learning from Case-Study Research. Journal of Research Practice, 2 (1). Elérhetőség: http://jrp.icaap.org/index.php/jrp/article/view/23 (Letöltve: 2018.12.03.).

Bloom, B.S. (1956): Taxonomy of educational objectives. Vol. 1: Cognitive domain. New York: McKay, pp. 20-24.

Bodnár É. (2007): Az e-tanulótípusok tanulási attitüdje. Pécsi Tudományegytem.

Bodnár, É., Csillik, O., Daruka, M., et al. (2017): Varázsszer-e a tükrözött osztályterem? Budapest: Budapesti Corvinus Egyetem Tanárképző és Digitális Tanulás Központ.

Bodnár, É. és Sass, J. (2015): A kognitív stílus mint online tanulási környezetet perszonalizáló tényező, In: Szerk.: Ujhelyi Adrienn, Szerk.: Lévai Dóra VII. OktatásInformatikai Konferencia : tanulmánykötet. Budapest: ELTE PPK Neveléstudományi Intézet

Boland, R.J. és Collopy, F. (2004): Design matters for management. Stanford University Press.

Bondarouk, T. és Ruël, H. (2010): Dynamics of e-learning: theoretical and practical perspectives: Introduction to special issue. International Journal of Training and Development, 14 (3): 149-154. doi:10.1111/j.1468-2419.2010.00348.x.

Boroujerdi, S.S. és Hasani, K. (2013): Relationship between Knowledge Management and Employee Empowerment in the Sport and Youth Organization of Iran. International Journal of Research in Organizational Behavior and Human Resource Management, 1 (4): 195-209. 
Bouhnik, D. és Marcus, T. (2006): Interaction in distance-learning courses. Journal of the American Society for Information Science and Technology, 57 (3): 299-305. doi:10/ffbptg.

Boyle, T. (1997): Design for multimedia learning. Prentice-Hall, Inc.

Bradbury-Huang, H. (2010): What is good action research?: Why the resurgent interest? Action Research, 8 (1): 93-109. doi:10/bj3j45.

Brady, K.P., Holcomb, L.B. és Smith, B.V. (2010): The Use of Alternative Social Networking Sites in Higher Educational Settings: A Case Study of the E-Learning Benefits of Ning in Education. Journal of Interactive Online Learning, 9 (2): 152-170.

Brown, T. (2008): Design thinking. Harvard business review, 86 (6): 84-92.

Brown, T. és Katz, B. (2011): Change by design. Journal of product innovation management, 28 (3): 381-383. doi:10/brrm23.

Bukowitz, W. és Williams, R.L. (1999): The Knowledge Management Fieldbook. London: FT Press.

Burbules, N.C. és Callister, T.A. (1999): The Risky Promises and Promising Risks of New Information Technologies for Education. Bulletin of Science, Technology \& Society, 19 (2): 105-112. doi:10/dqdwh5.

Burkhardt, H. és Schoenfeld, A.H. (2003): Improving Educational Research:Toward a More Useful, More Influential, and Better-Funded Enterprise. Educational Researcher, 32 (9): 3-14. doi:10/c3n76b.

Busstra, M.C., Hartog, R., Kersten, S., et al. (2007): Design guidelines for the development of digital nutrigenomics learning material for heterogeneous target groups. Advances in Physiology Education, 31 (1): 67-75. doi:10/cwh8wh.

Cantoni, V., Cellario, M. és Porta, M. (2004): Perspectives and challenges in elearning: towards natural interaction paradigms. Journal of Visual Languages \& Computing, 15 (5): 333-345. doi:10/dsrhcm.

Capper, J. (2001): E-Learning Growth and Promise. TechKnowLogia, 2 (2): 7-10.

Carneiro, T., Medeiros Da Nobrega, R.V., Nepomuceno, T., et al. (2018): Performance Analysis of Google Colaboratory as a Tool for Accelerating Deep Learning Applications. IEEE Access, 6: 61677-61685. doi:10/gf6crc.

Cassidy, A. (2002): A Practical Guide to Planning for E-Business Success: How to Eenable Your Enterprise. CRC Press LLC.

Cavoukian, A. (2011): Privacy by Design: Origins, meaning, and prospects for assuring privacy and trust in the information era. Privacy Protection Measures and Technologies in Business Organizations: Aspects and Standards, pp. 170-208. doi:10/bs6x $8 \mathrm{~m}$. 
Chang, V. (2016): Review and discussion: E-learning for academia and industry. doi:10.1016/j.ijinfomgt.2015.12.007.

Chen, M. és Purdin, T.D.M. (1990): Systems Development in Information Systems Research. Journal of Management Information Systems, 7 (3): 89-106. doi:10/gdz5rh.

Churchill, D. (2007): Towards a useful classification of learning objects. Educational Technology Research and Development, 55 (5): 479-497. doi:10/bt5wck.

Click, J.W. és Baird, R.N. (1974): Magazine editing and production. Dubuque, Iowa: W.C. Brown Co.

Cobb, P., Confrey, J., diSessa, A., et al. (2003): Design Experiments in Educational Research. Educational Researcher, 32 (1): 9-13. doi:10/fv7rqx.

Cobb, P., Jackson, K. és Dunlap, C. (2016): Design research: An analysis and critique. Handbook of international research in mathematics education, pp. 481-503.

Coghlan, D. (2002): Putting "Research" Back into OD and Action Research: A Call to OD Practitioners. Organization Development Journal, 20 (1): 62-65.

Cole, R., Purao, S., Rossi, M., et al. (2005): Being Proactive: Where Action Research Meets Design Research. ICIS International Conference on Information Systems, Las Vegas, USA, December 11-14, 2005. Elérhetőség: https://research.aalto.fi/en/publications/being-proactive-where-action-researchmeets-design-research(e56704da-2a58-4106-8da3-0588c7651c49)/export.html (Letöltve: 2018.06.15.).

Collins, A. (1992): “Toward a Design Science of Education.” In Scanlon, E. and O'Shea, T. (eds.). New Directions in Educational Technology. NATO ASI Series 1992. Springer Berlin Heidelberg. pp. 15-22.

Comella-Dorda, S., C. Dean, J., Morris, E., et al. (2002): A Process for COTS Software Product Evaluation. In Ottawa, Ontario, 40 2002. National Research Council of Canada. pp. 86-96. doi:10/dwh4xf.

Crossan, M.M., Lane, H.W. és White, R.E. (1999): An Organizational Learning Framework: From Intuition to Institution. The Academy of Management Review, 24 (3): 522-537. doi:10/d2ccm2.

Crowe, M. and Sheppard, L. (2012): Mind mapping research methods. Quality \& Quantity, 46 (5): 1493-1504. doi:10/btv4m3.

Csedő Z., Tóth T., Égler A., et al. (2014): Online képzési stratégiák és módszerek a közszolgálati továbbképzésekben. Információs Társadalom, XIV. (1): 9-28.

Csillag, S. (2016): A kooperatív akciókutatás elmélete és gyakorlata.

Csizmadia, P. (2015): A szervezeti innováció és tudásfelhasználás mintái a magyar gazdaságban. Doktori (PhD): értekezés, Budapesti Corvinus Egyetem. 
Csoma G. (2003): "Hipotézisek az e-learningröl." In Az e-learning szerepe a felnöttoktatásban és -képzésben. Budapest: Magyar Pedagógiai Társaság Felnőttnevelési Szakosztály.

Curley, M. és Salmelin, B. (2017): Open Innovation 2.0: The New Mode of Digital Innovation for Prosperity and Sustainability. Springer.

Davenport, T.H. és Short, J.E. (1990): The new industrial engineering: information technology and business process redesign.

De Smet, A., Lund, S. és Schaninger, W. (2016): Organizing for the future. McKinsey Quarterly, 1: 1-14.

Degryse, C. (2016): Digitalisation of the Economy and its Impact on Labour Markets. doi:10.2139/ssrn.2730550.

Demeter, K. (2009): Szolgáltatások versenyképességének elemzése vállalati példák alapján. Vezetéstudomány-Budapest Management Review, 40 (3): 29-37.

Demeter, K., Szász, L. és Kö, A. (2018): A text mining based overview of inventory research in the ISIR special issues 1994-2016. International Journal of Production Economics, 209: 134-146. doi:10/gf6cqq.

Denscombe, M. (2010): The Good Research Guide: For Small-Scale Social Research Projects: for small-scale social research projects. 4 edition. Maidenhead: Open University Press.

Despa, M.L. (2014): Comparative study on software development methodologies. Database Systems Journal, V (3): 37-56.

Devins, D. és Jones, B. (2016): Strategy for succession in family owned small businesses as a wicked problem to be tamed. Vezetéstudomány / Budapest Management Review, 47 (11): 4-15. doi:10/gf6crm.

Dichev, C., Dicheva, D., Angelova, G., et al. (2015): From Gamification to Gameful Design and Gameful Experience in Learning. Cybernetics and Information Technologies, 14 (4): 80-100. doi:10/gfxm8r.

Diederen, J., Gruppen, H., Hartog, R., et al. (2003): Design of Activating Digital Learning Material for Food Chemistry Education. Chem. Educ. Res. Pract., 4 (3): $353-$ 371. doi:10/gf6cqv.

Dierkes, M., Antal, A.B., Child, J., et al. (eds.): (2003): Handbook of Organizational Learning and Knowledge. New York, NY, USA: Oxford University Press, Inc.

Dror, I. (2008): Technology enhanced learning: The good, the bad, and the ugly. doi:10.1075/pc.16.2.02dro.

Dym, C.L., Agogino, A.M., Eris, O., et al. (2005): Engineering Design Thinking, Teaching, and Learning. Journal of Engineering Education, pp. 103-120. doi:10/gd23pm. 
van Eck, N.J. és Waltman, L. (2010): Software survey: VOSviewer, a computer program for bibliometric mapping. Scientometrics, 84 (2): 523-538. doi:10/cx2w6z.

Elkins, D. és Pinder, D. (2015): E-Learning Fundamentals: A Practical Guide. American Society for Training and Development. (Google-Books-ID: P_tcDwAAQBAJ).

Endrédy, I. és Novák, A. (2015): Szótövesítő programok összehasonlítása és alkalmazásaik. Alkalmazott nyelvtudomáány, 15. (1-2.): 7-27.

Engeström, Y. (2004): “The New Generation of Expertise: Seven theses.” In Rainbird, H., Fuller, A. és Munro, A. Workplace learning in context. Psychology Press.

Evans, M. és Ali, N. (2013): Bridging Knowledge Management Life Cycle Theory and Practice. Proceedings of the International Conference on Intellectual Capital, Knowledge Management \& Organizational Learning, pp. 156-165.

Fallon, K. (2016): Innovation Myth \#2: Fail Fast, Fail Often is the Secret to Innovation Elérhetöség: http://www.pivotalinnovation.com/Blog/ArtMID/564/ArticleID/15/Innovation-Myth2-Fail-Fast-Fail-Often-is-the-Secret-to-Innovation (Letöltve: 2018.06.22.).

Farrand, P., Hussain, F. és Hennessy, E. (2002): The efficacy of the "mind map" study technique. Medical Education, 36 (5): 426-431.

Farrell, R. és Hooker, C. (2013): Design, science and wicked problems. Design Studies, 34: 681-705. doi:10/f5ddfr.

Fehér P. (2004): Tudásmenedzsmentet támogató tényezők szerepe szoftverfejlesztö szervezetekben. Doktori (PhD): értekezés, Budapesti Corvinus Egyetem.

Fehér P. (2018): A digitális átalakulás módszereinek feltárása a közszolgáltatásokban - a design thinking módszertan alkalmazási lehetőségei. Vezetéstudomány / Budapest Management Review, 49 (7-8): 22-31. doi:10/gf6cqp.

Fehér, P. és Varga, K. (2017): Using Design Thinking to identify banking digitization opportunities.

Firestone, J.M. és McElroy, M.W. (2004): Organizational learning and knowledge management: the relationship. The Learning Organization, 11 (2): 177-184. doi:10/fpxfjc.

Flick, U. (2004): Triangulation in qualitative research. A companion to qualitative research, 3: 178-183.

Flyvbjerg, B. (2006): Five Misunderstandings About Case-Study Research. Qualitative Inquiry, 12 (2): 219-245. doi:10/fsd688.

Friedman, J., Hastie, T. és Tibshirani, R. (2000): Additive Logistic Regression: A Statistical View of Boosting. The Annals of Statistics, 28 (2): 337-407. doi:10/dh4m2b. 
Gajdács, M. (2019): A bibliometric analysis of Acta Pharmaceutica Hungarica (19652018). Acta Pharmaceutica Hungarica, 89 (1): 23-29. doi:10/gf6cqm.

Galagan, P. (2000): The E-Learning Revolution.

Gallego, D., Barra, E., Gordillo, A., et al. (2013): "Enhanced recommendations for eLearning authoring tools based on a proactive context-aware recommender." In 2013 IEEE Frontiers in Education Conference (FIE). Oklahoma City, OK, USA, October 2013. IEEE. pp. 1393-1395. doi:10/gf6cq3.

Galloway, D.L. (2005): Evaluating distance delivery and e-learning is kirkpatrick's model relevant? Performance Improvement, 44 (4): 21-27. doi:10/bc95bj.

Gallupe, R.B. (2007): The Tyranny of Methodologies in Information Systems Research1. SIGMIS Database, 38 (3): 20-28. doi:10/dttgk3.

García-Morales, V.J., Llorens-Montes, F.J. és Verdú-Jover, A.J. (2006): Antecedents and consequences of organizational innovation and organizational learning in entrepreneurship. Industrial Management \& Data Systems, 106 (1): 21-42. doi:10/bxqfhq.

Garg, R. (2017): A systematic review of COTS evaluation and selection approaches. Accounting, pp. 227-236. doi:10.5267/j.ac.2017.1.003.

Garrison, D.R. és Kanuka, H. (2004): Blended learning: Uncovering its transformative potential in higher education. The Internet and Higher Education, 7 (2): 95-105. doi:10/b6g4vc.

Gates, B. (1996): Content is king. Retrieved October, 29.

Genemo, H., Miah, S.J. és McAndrew, A. (2016): A design science research methodology for developing a computer-aided assessment approach using method marking concept. Education and Information Technologies, 21 (6): 1769-1784. doi:10/gf6cqn.

Gerring, J. (2006): Case study research: Principles and practices. Cambridge university press.

Giacumo, L. és Conley, Q. (2015): E-Learning Authoring Software Selection: How Do Instructional Designers Gain Competency Using and Selecting Appropriate Digital Media Development Tools? 38th Annual AECT Convention Proceedings, Selected Research and Development Papers: 87-95.

Gibson, J.W., Greenwood, R.A. és Murphy, E.F., Jr (2009): Generational Differences In The Workplace: Personal Values, Behaviors, And Popular Beliefs. Journal of Diversity Management, 4 (3): 1-7.

Gilbert, J., Morton, S. és Rowley, J. (2007): e-Learning: The student experience. British Journal of Educational Technology, 38 (4): 560-573. doi:10/bx2fxv. 
GKI D. (2016): Így vélekedik a munkáról a Z generáció. GKI Digital. Elérhetőség: http://gkidigital.hu/2016/06/15/igy-velekedik-a-munkarol-a-z-generacio/ (Letöltve: 2018.04.20.).

Gleasure, R. (2013): "What is a 'wicked problem'for IS research." In SIG Prag Workshop Tilburg, The Netherlands. 2013.

González, A. (2018): Instructional Design and Learning Experience Design. Elérhetőség: https://medium.com/@alejandroglezf/instructional-design-and-learningexperience-design-5625d91686ca (Letöltve: 2019.08.12.).

Govindasamy, T. (2002): Successful implementation of e-Learning Pedagogical considerations. Internet and Higher Education, 4: 287-299.

Gregor, S. és Hevner, A.R. (2013): Positioning and Presenting Design Science Research for Maximum Impact. MIS Quarterly, 37 (2): 337-355. doi:10.25300/MISQ/2013/37.2.01.

Griggs, K.A., Wild, R.H. és Downing, T. (2002): A framework for e-learning as a tool for knowledge management. Industrial Management \& Data Systems, 102 (7): 371380. doi:10/cc7bsp.

Gunasekaran, A., McNeil, R.D. és Shaul, D. (2002): E-learning: research and applications. Industrial and commercial training, 34 (2): 44-53. doi:10/bf6wrz.

Guo, P.J., Kim, J. és Rubin, R. (2014): "How video production affects student engagement: an empirical study of MOOC videos." In Proceedings of the first ACM conference on Learning @ scale conference - L@S '14. Atlanta, Georgia, USA, 2014. ACM Press. pp. 41-50. doi:10/tp6.

Guralnick, D. és Levy, C. (2009): Enabling Effective E-Learning Creation on a Large Scale: Special-Purpose Authoring Tools. International Journal of Emerging Technologies in Learning (iJET), 4 (s3). doi:10/fw9hvj.

Gutierrez, K. (2017): 5 Business Challenges You Want to Overcome Today (and How to Fix These With eLearning). Elérhetöség: https://www.shiftelearning.com/blog/business-challenges-fix-these-with-elearning (Letöltve: 2019.08.13.).

Habók, A. (2009): Egy térképezö technika hatásának vizsgálata általános iskolában.

Halawi, L.A., McCarthy, R.V. és Pires, S. (2009): An Evaluation of E-Learning on the Basis of Bloom's Taxonomy: An Exploratory Study. Journal of Education for Business, 84 (6): 374-380. doi:10/fswscd.

Hámori, B. (2012): Tanulás és innováció - Elméleti dilemmák és gyakorlati nézöpontok (Learning and innovation - Theoretical dilemmas and practical point of views). 
Hámornik, B.P. és Juhász, M. (2010): Knowledge sharing in medical team: knowledge, knowledge management, and team knowledge. Periodica Polytechnica Social and Management Sciences, 18 (2): 103-111. doi:10/gf6cq7.

Hámornik B.P. és Nagy E. (2018): Munkaerő megtartás lehetőségei a kiberbiztonsági teamekben. Hadmérnök, XIII. (4.): 285-296.

Hanelt, A., Piccinini, E., Gregory, R.W., et al. (2015): Digital Transformation of Primarily Physical Industries - Exploring the Impact of Digital Trends on Business Models of Automobile Manufacturers. 12th International Conference on Wirtschaftsinformatik, pp. 1313-1327.

Harangi L. és Kelner G. (2003): Az e-learning szerepe a felnöttoktatásban és képzésben. Budapest: Magyar Pedagógiai Társaság Felnőttnevelési Szakosztály.

Hellmuth, W. és Stewart, G. (2014): Using Enterprise Information Architecture Methods to Model Wicked Problems in Information Systems Design Research Semantic Scholar. Elérhetőség: /paper/Using-Enterprise-Information-ArchitectureMethods-Hellmuth-Stewart/586110a02847b82ad0f9da6fa993b95feeb61761 (Letöltve: 2018.06.22.).

Hercegfi, K., Csillik, O., Bodnár, É., et al. (2009): “Designers of Different Cognitive Styles Editing E-Learning Materials Studied by Monitoring Physiological and Other Data Simultaneously." In Harris, D. (ed.). Engineering Psychology and Cognitive Ergonomics. Lecture Notes in Computer Science 2009. Springer Berlin Heidelberg. pp. 179-186.

Herendi K. (2017): Iránytüre van szükséged, nem térképre - a Tervezd meg az életed címü könyvet ajánljuk. Pszichoforyou Szívvel. Lélekkel. Neked. Elérhetőség: http://pszichoforyou.hu/tervezd-meg-az-eleted/ (Letöltve: 2018.07.13.).

Herselman, M. és Botha, A. (2015): "Evaluating an Artifact in Design Science Research." In Proceedings of the 2015 Annual Research Conference on South African Institute of Computer Scientists and Information Technologists. SAICSIT '15 New York, NY, USA, 2015. ACM. doi:10/gf6cq4.

Hevner, A. (2007): A Three Cycle View of Design Science Research.

Hevner, A. és Chatterjee, S. (2010): Design Research in Information Systems: Theory and Practice. Integrated Series in Information Systems. Springer US. Elérhetöség: //www.springer.com/us/book/9781441956521 (Downloaded: 15 June 2018).

Hevner, A., March, T.S., Park, J., et al. (2004): Design Science in Information Systems Research., 28.

Holmström, J., Ketokivi, M. és Hameri, A.-P. (2009): Bridging Practice and Theory: A Design Science Approach. Decision Sciences, 40 (1): 65-87. doi:10/crqxds.

Horton, W. és Horton, K. (2003): E-learning Tools and Technologies: A consumer's guide for trainers, teachers, educators, and instructional designers. John Wiley \& Sons. (Google-Books-ID: fyDS2crqAbgC). 
Hughes, G. és Hay, D. (2001): Use of concept mapping to integrate the different perspectives of designers and other stakeholders in the development of e-learning materials. British Journal of Educational Technology, 32 (5): 557-569. doi:10/bwjkvf.

Hung, J. (2012): Trends of e-learning research from 2000 to 2008: Use of text mining and bibliometrics: Research trends of e-learning. British Journal of Educational Technology, 43 (1): 5-16. doi:10/dsb6m9.

I-Chin Wu és Wen-Shan Chen (2013): Evaluating the E-Learning Platform from the Perspective of Knowledge Management: The AHP Approach. Journal of Library and Information Studies, Vol 11, Iss 1, Pp 1-24 (2013), 11 (1): 1-24. doi:10/gf6crd.

Iivari, J. (2007): A Paradigmatic Analysis of Information Systems As a Design Science. Scandinavian Journal of Information Systems, 19 (2). Elérhetöség: http://aisel.aisnet.org/sjis/vol19/iss2/5.

Järvinen, P. (2007): Action Research is Similar to Design Science. Quality \& Quantity, 41 (1): 37-54. doi:10/b8d9hv.

Javed, Z., Sattar, A.R. és Faridi, M.S. (2012): Unsolved Tricky Issues on COTS Selection and Evaluation. Global Journal of Computer Science and Technology Neural \& Artificial Intelligence, 12 (10).

Jung, I. (2011): The dimensions of e-learning quality: from the learner's perspective. Educational Technology Research and Development, 59 (4): 445-464. doi:10/bbp6fg.

Kaplan, R.S. (1998): Innovation Action Research: Creating New Management Theory and Practice. Elérhetőség: https://www.hbs.edu/faculty/Pages/item.aspx?num=3674 (Letöltve: 2018.09.07.).

Kayani, J. és Zia, M.Q. (2012): The analysis of knowledge, knowledge management and knowledge management cycles: A broad review. International Journal of Academic Research in Economics and Management Sciences, 1 (6).

Kelley, B. (2012): Don't Fail Fast - Learn Fast - Innovation Excellence. Innovation Excellence. Elérhetöség: http://innovationexcellence.com/blog/2012/07/16/dont-failfast-learn-fast/ (Letöltve: 2018.06.22.).

Khalil, M.K. és Elkhider, I.A. (2016): Applying learning theories and instructional design models for effective instruction. Advances in Physiology Education, 40 (2): 147-156. doi:10/gf6cqs.

Kimbell, L. (2011): Rethinking Design Thinking: Part I. Design and Culture, 3 (3): 285-306. doi:10/bnj6r6.

Kineo (2013): Getting your head around Design Thinking. Elérhetőség: https://www.kineo.com/insights/getting-your-head-around-design-thinking-learningstrategy-and-design (Letöltve: 2019.03.05.).

King, W.R. (2009): "Knowledge management and organizational learning." In Knowledge management and organizational learning. Springer. pp. 3-13. 
Kirkpatrick, D.L. (1977): Evaluating training programs: Evidence vs. proof. Training Dev J.

Klimkó, G. (2001): A szervezeti tudás feltérképezése = Mapping organisational knowledge. Doktori (PhD): értekezés, Budapesti Corvinus Egyetem. Elérhetöség: http://phd.lib.uni-corvinus.hu/179/ (Letöltve: 2018.04.13.).

Kö, A. (2004): Az információtechnológia szerepe és lehetöségei a tudásmenedzsmentben: Az ontológiaépítés, mint a tudásmenedzsment eszköze. Doktori $(\mathrm{PhD})$ : értekezés, Budapesti Corvinus Egyetem. Elérhetőség: http://phd.lib.unicorvinus.hu/183/ (Letöltve: 2018.10.19.).

Kö, A. (2011): Tudáskodifikáció a gyakorlatban - egy ontológia alapú e-learning rendszer alkalmazásának tapasztalatai.

Kő, A. és Klimkó, G. (2009): Towards a Framework of Information Technology Tools for Supporting Knowledge Management Noszkay, E. (ed.). Elérhetőség: https://www.researchgate.net/publication/280010190_Towards_a_Framework_of_In formation_Technology_Tools_for_Supporting_Knowledge_Management.

Kolko, J. (2015): Design Thinking Comes of Age. Harvard Business Review, pp. 1-7.

Komenczi, B. (2006): Az E-learning lehetséges szerepe a magyarországi felnőttképzésben: Kutatási zárótanulmány. Felnőttképzési Kutatási Füzetek. Budapest: NFI. Elérhetöség: http://mek.oszk.hu/06700/06773.

Koohang, A., Riley, L., Smith, T., et al. (2009): E-Learning and Constructivism: From Theory to Application. Interdisciplinary Journal of E-Learning and Learning Objects, (5): 91-109. doi:10.28945/3321.

Kovács I. (1996): Új út az oktatásban?: a távoktatás. Budapest: BKE Felsőoktatási Koordinációs Iroda.

Kovács, I. (2011): Az elektronikus tanulásról a 21. század első éveiben. Budapest: Szerző. Elérhetőség: http://mek.oszk.hu/09100/09190.

Kuhn, D. (2015): Thinking Together and Alone. Educational Researcher, 44 (1): 4653. doi:10/gfj8jh.

Kunda, D. és Brooks, L. (1999): Applying Socal-Technical Approach for COTS selection. Information Systems, Proceedings of 4th UKAIS Conference: 1-15.

Kurt, S. (2017): ADDIE Model: Instructional Design. Educational Technology. Elérhetőség: https://educationaltechnology.net/the-addie-model-instructional-design/ (Letöltve: 2019.03.05.).

Lam, A. (2000): Tacit Knowledge, Organizational Learning and Societal Institutions: An Integrated Framework. Organization Studies, 21 (3): 487-513. doi:10/c9dhjc.

Lam, A. (2004): Organizational Innovation. Munich Personal RePEc Archive, (11539). Elérhetőség: https://mpra.ub.uni-muenchen.de/11539/. 
Laurillard, D. (2013): Teaching as a Design Science: Building Pedagogical Patterns for Learning and Technology. Routledge. (Google-Books-ID: YNojRK6AEagC).

Lee, A.S. (1989): A scientific methodology for MIS case studies. MIS quarterly, pp. $33-50$.

Lee, M.-C. (2010): Explaining and predicting users' continuance intention toward elearning: An extension of the expectation-confirmation model. Computers \& Education, 54 (2): 506-516. doi:10/d5b5mn.

Lee, T.-S. és Tsai, H.-J. (2005): The effects of business operation mode on market orientation, learning orientation and innovativeness. Industrial Management \& Data Systems, 105 (3): 325-348. doi:10/fqmrq6.

Lengyelné Molnár T. (2013): Kutatástervezés, Médiainformatikai Kiadványok, Eger. Médiainformatikai Kiadványok.

Liao, S. és Wu, C. (2009): The Relationship among Knowledge Management, Organizational Learning, and Organizational Performance. International Journal of Business and Management, 4 (4): 64-76. doi:10/gf8g68.

Liaw, S.-S. (2008): Investigating students' perceived satisfaction, behavioral intention, and effectiveness of e-learning: A case study of the Blackboard system. Computers \& education, 51 (2): 864-873. doi:10/cr6dcm.

Lipman, A. (2019): How Elearning and Online Training Can Help in HR and Hiring | LearnWorlds Blog. Elérhetőség: https://www.learnworlds.com/elearning-traininghr-hiring\%E2\%80\%8B/ (Letöltve: 2019.08.13.).

Loizou, B. (2016): A framework for innovation. Elérhetőség: http://www.billyloizou.com/1/post/2016/01/a-framework-for-innovation-

designthinking.html (Letöltve: 2019.03.12.).

Mahmud, I. és Veneziano, V. (2011): "Mind-mapping: An effective technique to facilitate requirements engineering in agile software development." In 14th International Conference on Computer and Information Technology (ICCIT 2011). Dhaka, Bangladesh, December 2011. IEEE. pp. 157-162. doi:10/gf6cq9.

Mandinach, E.B. (2005): The Development of Effective Evaluation Methods for ELearning: A Concept Paper and Action Plan. Teachers College Record, 107 (8): 18141835. doi:10/chdq9g.

March, S.T. és Smith, G.F. (1995): Design and Natural Science Research on Information Technology. Decis. Support Syst., 15 (4): 251-266. doi:10/bzbxcz.

Margolin, V. (2002): The Politics of the Artificial. Chicago: University of Chicago Press.

https://www.press.uchicago.edu/ucp/books/book/chicago/P/bo3623186.html

(Downloaded: 21 December 2018). 
Margolin V. (2014): A designtanulmányok összetett feladata. Disegno - $a$ designkultúra folyóirata, I. (1.): 46-61.

Margolis, A.R., Porter, A.L. és Pitterle, M.E. (2017): Best Practices for Use of Blended Learning. American Journal of Pharmaceutical Education, 81 (49).

McElroy, M.W. (2002): The New Knowledge Management: Complexity, Learning, and Sustainable Innovation. 1 edition. Hartland Four Corners, Vt: Amsterdam; Boston: Butterworth-Heinemann.

McIntosh, D. (2018): Vendors of Learning Management and eLearning Products. Elérhetőség:

https://teachonline.ca/sites/default/files/.../vendors_of_elearning_products_mar2017. pdf.

Mendelow, A. (1991): "Stakeholder mapping." In Proceedings of the 2nd international conference on information systems, Cambridge, MA. 1991.

Merriam, S.B. (1998): Qualitative Research and Case Study Applications in Education. Revised and Expanded from" Case Study Research in Education.". ERIC.

Merrill, M.D., Drake, L., Lacy, M.J., et al. (1996): Reclaiming Instructional Design. Educational Technology, 36 (5): 5-7.

Milewska, E. (2017): The Design Thinking Method and Its Stages., 6 (6): 247-255.

Millard, J., Shahin, J., Leitner, C., et al. (2006): Towards the eGovernment Vision for the EU in 2010: Research Policy Challenges. Institute for Prospective Technological Studies.

Mohd Alwi, N.H. és Fan, I.-S. (2010): E-Learning and Information Security Management. International Journal for Digital Society, 1 (2): 148-156. doi:10/gf6cq2.

Moisio, A. és Smeds, R. (2004): E-learning: a service offering. Knowledge and Process Management, 11 (4): 252-260. doi:10/dfncpz.

Molas-Castells, N. és Fuertes-Alpiste, M. (2018): E-Learning Research Report 2017. Analysis of the main topics in research indexed articles. Universitat Oberta de Catalunya (UOC). doi:10.7238/elc.report.2018.

Molnár, G. (2015): “Teaching and learning in modern digital environment.” In 2015 IEEE 13th International Symposium on Applied Machine Intelligence and Informatics (SAMI). Herl'any, Slovakia, January 2015. IEEE. pp. 213-217. doi:10/gf6crn.

Monda E. (2018): Az információrendszerek és a jövőkutatás összekapcsolása és értelmezése a döntéstámogatásban. Doktori ( $\mathrm{PhD})$ : értekezés, Budapesti Corvinus Egyetem, Gazdaságinformatika Doktori Iskola. DOI 10.14267/phd.2018031.

Moore, J.F. (1996): The death of competition: leadership and strategy in the age of business ecosystems. New York, NY, USA: Harper Business. 
Myers, M.D. és Venable, J.R. (2014): A set of ethical principles for design science research in information systems. Information \& Management, 51 (6): 801-809. doi:10/gd3vw5.

Nemeslaki, A. (2011a): Advanced blended learning techniques for educating civil servants. Pro Publico Bono Online Támop Speciál. Elérhetőség: http://m.ludita.uninke.hu/repozitorium/handle/11410/1787.

Nemeslaki, A. (2011b): Existing Challenges and Deficiencies of Information Management in the ICT era. Habilitation, Budapesti Corvinus Egyetem.

Nemeslaki, A. (2011c): Tüz és víz határán a gazdaságinformatikában: A technológiai konstruálás és a társadalmi konstruktivizmus összekapcsolásának lehetösége. doi:http://hdl.handle.net/11410/1607.

Nemeslaki, A. (2012): Vállalati internetstratégia. Akadémiai Kiadó.

Nemeslaki, A. (2018): Application of Science-Technology Society studies in Information Security research - Review of journals for theory and advanced research design. Academic and Applied Research in Military and Public Management Science, 17 (1): 87-140.

Newcombe, R. (2003): From client to project stakeholders: a stakeholder mapping approach. Construction Management and Economics, 21 (8): 841-848. doi:10/bdgbp3.

Niemiec, C.P. és Ryan, R.M. (2009): Autonomy, competence, and relatedness in the classroom: Applying self-determination theory to educational practice. Theory and Research in Education, 7 (2): 133-144. doi:10/bmwfzs.

Nonaka, I., Nonaka, I. o, Ikujiro, N., et al. (1995): The Knowledge-creating Company: How Japanese Companies Create the Dynamics of Innovation. Oxford University Press.

Nonaka, I. és Toyama, R. (2003): The knowledge-creating theory revisited: knowledge creation as a synthesizing process. Knowledge Management Research \& Practice, 1: 2-10. doi:10/dfj86c.

Noor, K.B.M. (2008): Case study: A strategic research methodology. American journal of applied sciences, 5 (11): 1602-1604. doi:10/c58ftt.

North-Samardzic, A. (2015): Design science for management education: Developing and testing an online simulation. doi:10.5465/AMBPP.2015.15491abstract.

Noweski, C., Scheer, A., Büttner, N., et al. (2012): "Towards a Paradigm Shift in Education Practice: Developing Twenty-First Century Skills with Design Thinking." In Plattner, H., Meinel, C. és Leifer, L. (eds.): Design Thinking Research. Berlin, Heidelberg: Springer Berlin Heidelberg. pp. 71-94. doi:10.1007/978-3-642-319914_5. 
Offermann, P., Levina, O., Schönherr, M., et al. (2009): Outline of a design science research process. In 2009. ACM Press. doi:10.1145/1555619.1555629.

Oliver, M. (2011): Technological determinism in educational technology research: some alternative ways of thinking about the relationship between learning and technology: Educational technology and determinism. Journal of Computer Assisted Learning, 27 (5): 373-384. doi:10/dknkhk.

Ollé J. (2018): “Oktatástervezés: a tevékenységközpontú digitális tananyag strukturális és módszertani sajátosságai." In Iskolakultúra és környezetpedagógia. Miskolc: Magyar Tudományos Akadémia, Miskolci Akadémiai Bizottság. pp. 59-68. Elérhetőség:

http://www.eltereader.hu/media/2018/07/Olle_Iskolakultura_READER_.pdf.

Orbán Z. és Balkányi P. (2015): E-learning tananyagok fejlesztése a közigazgatásban. Pro Publico Bono: Magyar Közigazgatás, (4): 100-111.

Orlikowski, W.J. (1993): Learning from notes: Organizational issues in groupware implementation. The Information Society, 9 (3): 237-250. doi:10/crs4x5.

Örtenblad, A. (2013): The learning organization: towards an integrated model. The Learning Organization. doi:10/db5n34.

Oyelere, S.S., Suhonen, J., Wajiga, G.M., et al. (2018): Design, Development, and Evaluation of a Mobile Learning Application for Computing Education. Education and Information Technologies, 23 (1): 467-495. doi:10/gf6cqx.

Pandey, S. (2018): 6 Stages of Design Thinking Process \& How To Master It. WPEka Blog. Elérhetőség: https://www.wpeka.com/stages-of-design-thinking.html (Letöltve: 2019.03.12.).

Parsons, J., Gokey, C. és Thorton, M. (2013): Indicators of Inputs, Activities, Outputs, Outcomes and Impacts in Security and Justice Programming. Vera Institute of Justice.

Peffers, K., Tuunanen, T., Rothenberger, M., et al. (2007): A Design Science Research Methodology for Information Systems Research. J. Manage. Inf. Syst., 24 (3): 45-77. doi:10/cxnmc8.

Pólya B. és Martos T. (2012): Why is it good to be a volunteer? The connection between voluntary work and life satisfaction using the Self-Determination Theory. Mentálhigiéné és Pszichoszomatika, 13 (3): 255-271. doi:10/gf6tm6.

Poór, J., Sasvari, P., Nesterowicz, K., et al. (2016): E-learning in Management - Focus on Hungary, Serbia and Slovakia. Journal of Management and Financial Sciences, 9.

Prediger, S., Gravemeijer, K. és Confrey, J. (2015): Design research with a focus on learning processes: an overview on achievements and challenges. ZDM, 47 (6): 877891. doi:10/gf6cqw. 
Probst, G., Raub, S. és Romhardt, K. (2006): Wissen managen: Wie Unternehmen ihre wertvollste Ressource optimal nutzen 5., überarb. A., Wiesbaden: Gabler, Betriebswirt. Vlg.

Ramos, J. (2003): Using TF-IDF to Determine Word Relevance in Document Queries.

Rapoport, R.N. (1970): Three Dilemmas in Action Research: With Special Reference to the Tavistock Experience. Human Relations. doi:10/d4xskk.

Reiser, R.A. és Dempsey, J.V. (2012): Trends and issues in instructional design and technology. Pearson Boston.

Rittel, H.W.J. és Webber, M.M. (1973): Dilemmas in a general theory of planning. Policy Sciences, IV (2): 155-169. doi:10/c8mscz.

Robinson, K. (2011): Out of our minds: Learning to be creative. John Wiley \& Sons.

Rodgers, P. és Yee, J. (2014): The Routledge Companion to Design Research. Routledge. (Google-Books-ID: 1YbZBAAAQBAJ).

Rosemann és Vessey (2008): Toward Improving the Relevance of Information Systems Research to Practice: The Role of Applicability Checks. MIS Quarterly, 32 (1): 1-22. doi:10/gf6crq.

Ryan, R.M. és Deci, E.L. (2000): Self-Determination Theory and the Facilitation of Intrinsic Motivation, Social Development, and Well-Being. American Psychologist, 55 (1): 68-78. doi:10.1037110003-066X.55.1.68.

Sagor, R. (2000): Guiding School Improvement with Action Research. ASCD. (Google-Books-ID: W5VRDwAAQBAJ).

Sántha, K. (2007): A kvalitatív metodológiai követelmények problémái. Iskolakultúra, 17 (6-7): 168-177.

Sargent, P. (1991): Satisfactory Design Theory?

Savage, J. (2000): Participative Observation: Standing in the Shoes of Others? Qualitative Health Research, 10 (3): 324-339. doi:10/bd9brk.

Scheer, A., Noweski, C. és Meinel, C. (2012): Transforming constructivist learning into action: Design thinking in education. Design and Technology Education: An International Journal, 17 (3).

Schnellbach, M. (2019): Elearning-tananyagra adott visszajelzések elemzése. Google. Elérhetöség: https://colab.research.google.com/.

Schoenfeld A.H. (2006): “Design Experiments.” In Elmore I.P.B., Camilli G. és Green J. Handbook of Complementary Methods in Education Research. Washington, DC \& Mahwah, NJ: American Educational Research Association and Lawrence Erlbaum Associates. pp. 193-206. 
Scholes, K., Johnson, G. és Whittington, R. (2002): Exploring corporate strategy. Financial Times Prentice Hall.

Schwaber, K. (2004): Agile project management with Scrum. Microsoft press.

Schwalbe, K. (2015): Introduction to project management. Fifth edition. Minneapolis, MN: Schwalbe Publishing.

Scupelli, P. (2017): Opening a Design Education Pipeline from University to K-12 and Back.

Sein, M.K., Henfridsson, O., Purao, S., et al. (2011): Action Design Research. MIS Q., 35 (1): 37-56. doi:10/gd249s.

Senge, P.M. (1991): The fifth discipline, the art and practice of the learning organization. Performance+ Instruction, 30 (5): 37-37. doi:10/d96w23.

Serrat, O. (2017): "Building a Learning Organization." In Serrat, O. (ed.): Knowledge Solutions: Tools, Methods, and Approaches to Drive Organizational Performance. Singapore: Springer Singapore. pp. 57-67. doi:10.1007/978-981-10-0983-9_11.

Shea, P. (2006): A study of students' sense of learning community in online enviroments. Journal of Asynchronous Learning Networks, 10 (1): 35-44.

Shelton, K. (2010): A quality scorecard for the administration of online education programs: A delphi study. Journal of Asynchronous Learning Networks, 14 (4): 3662.

Shelton, K. (2011): A review of paradigms for evaluating the quality of online education programs. Online Journal of Distance Learning Administration, 4 (1): 1-9.

Sinclair, P.M., Kable, A., Levett-Jones, T., et al. (2016): The effectiveness of Internetbased e-learning on clinician behaviour and patient outcomes: A systematic review. International Journal of Nursing Studies, 57: 70-81. doi:10/f8nbff.

Slater, S.F. és Narver, J.C. (1995): Market Orientation and the Learning Organization. Journal of Marketing, 59 (3): 63-74. doi:10.1177/002224299505900306.

Slézia, J. (2012): Nemzetközi bútordesign irányzatok a 21. század elsö évtizedében. Doktori (PhD): értekezés, NYME. Elérhetőség: http://doktori.nyme.hu/379/ (Letöltve: 2018.07.13.).

Stake, R.E. (1995): The Art of Case Study Research. SAGE. (Google-Books-ID: ApGdBx76b9kC).

Steffe, L. és Thompson, P. (2000): Teaching experiment methodology: Underlying principles and essential elements. In pp. 267-307.

Sullivan, J. (2005): Rethinking Strategic HR. CCH Incorporated.

Susman, G.I. és Evered, R.D. (1978): An Assessment of the Scientific Merits of Action Research. Administrative Science Quarterly, 23 (4): 582-603. doi:10/c4zvqn. 
Swann, C. (2002): Action Research and the Practice of Design. Design Issues, 18 (1): 49-61. doi:10/bwn2cp.

Szabó, Z. (2000): A szervezeti információfeldolgozás strukturális és technológiai tényezőinek összerendelése. Doktori (PhD): értekezés, Budapesti Corvinus Egyetem. Elérhetőség: http://phd.lib.uni-corvinus.hu/212/ (Letöltve: 2019.03.04.).

Szabó, Z. és Fehér, P. (2010): "Management of IT Services-A Snapshot on Hungary." In Proceedings of the Fourth International Conference on Software, Knowledge, Information Management and Applications. Paro: College of Arts, Media and Technology Chiang Mai University. pp. 18-24.

Szimkovics, T. (2016): Online kurzuskészités oktatásának elméleti és gyakorlati kérdései a pedagógusképzésben.

Szokolszky, Á. (2004): Kutatómunka a pszichológiában. Osiris Kiadó, Budapest, pp. 450-453.

T. Osguthorpe, R. és Graham, C. (2003): Blended Learning Environments: Definitions and Directions.

Tan P.-N., Steinbach M. és Kumar V. (2011): Bevezetés az adatbányászatba. Panem. Elérhetőség:

https://www.tankonyvtar.hu/hu/tartalom/tamop425/0046_adatbanyaszat/adatok.html.

Temesi, J. (2002): A döntéselmélet alapjai. Budapest: Aula.

Tibaná-Herrera, G., Fernández-Bajón, M.T. és De Moya-Anegón, F. (2018): Categorization of E-learning as an emerging discipline in the world publication system: a bibliometric study in SCOPUS. International Journal of Educational Technology in Higher Education, 15 (1). doi:10/gf6cqt.

Török, M. (2014): Szervezeti tudás kinyerése üzleti folyamatmodellekből. Doktori $(\mathrm{PhD})$ : értekezés, Budapesti Corvinus Egyetem, Gazdaságinformatika Doktori Iskola. DOI 10.14267/phd.2014077.

Tretsiakova-McNally, S., Maranne, E., Verbecke, F., et al. (2017): Mixed e-learning and virtual reality pedagogical approach for innovative hydrogen safety training of first responders. International Journal of Hydrogen Energy, 42 (11): 7504-7512. doi:10/gf6cq8.

Urh, M., Vukovic, G., Jereb, E., et al. (2015): The Model for Introduction of Gamification into E-learning in Higher Education. Procedia - Social and Behavioral Sciences, 197: 388-397. doi:10/gfgxjh.

Vaishnavi, V. és Kuechler, W. (2004): Design Research in Information Systems.

Varannai, I., Sasvari, P. és Urbanovics, A. (2017): The Use of Gamification in Higher Education: An Empirical Study. International Journal of Advanced Computer Science and Applications, 8 (10). doi:10/gf6crp. 
Varga, K. (2014): A szemantikus folyamatmenedzsment hasznosítási lehetősége az üzleti folyamatok tudásalapú fejlesztésében. Doktori $(\mathrm{PhD})$ : értekezés, Budapesti Corvinus Egyetem, Gazdaságinformatika Doktori Iskola. DOI 10.14267/phd.2014078.

Vas, R. (2007): Educational Ontology and Knowledge Testing. The Electronic Journal of Knowledge Management, 5 (1): 123-130.

Venable, J., Pries-Heje, J. és Baskerville, R. (2016): FEDS: a Framework for Evaluation in Design Science Research. European Journal of Information Systems, 25 (1): 77-89. doi:10/f796x8.

Venable, J.R. (2010): "Design Science Research Post Hevner et al.: Criteria, Standards, Guidelines, and Expectations." In Winter, R., Zhao, J.L. és Aier, S. (eds.): Global Perspectives on Design Science Research. Berlin, Heidelberg: Springer Berlin Heidelberg. pp. 109-123. doi:10.1007/978-3-642-13335-0_8.

Veress, J.L. (2008): Az E-learning és az internetes távoktatásban rejlő lehetőségek fókuszban a fejlesztések sikerességi tényezői. E-conom, 5 (1): 51-64.

Weber, C. és Vas, R. (2015): "Studio: Ontology-Based Educational Self-Assessment." In EDM (Workshops).

Welsh, E.T., Wanberg, C.R., Brown, K.G., et al. (2003): E-learning: emerging uses, empirical results and future directions. International Journal of Training and Development, 7 (4): 245-258. doi:10/c64w5j.

Wentworth, D. (2014): 5 Trends for the Future of Learning and Development. Elérhetőség: https://trainingmag.com/5-trends-future-learning-and-development/ (Letöltve: 2019.04.11.).

Wieringa, R. (2009): "Design science as nested problem solving." In Proceedings of the 4th International Conference on Design Science Research in Information Systems and Technology - DESRIST '09. Philadelphia, Pennsylvania, 2009. ACM Press. doi:10/bn3vzv.

Wiig, K.M. (1993): Knowledge Management Foundations: Thinking about Thinkinghow People and Organizations Represent, Create, and Use Knowledge. Schema Press, Limited.

Wild, R.H., Griggs, K.A. és Downing, T. (2002): A framework for e-learning as a tool for knowledge management. Industrial Management \& Data Systems, 102 (7): 371380. doi:10/cc7bsp.

Wiley, D.A. (2000): Connecting learning objects to instructional design theory: A definition, a metaphor, and a taxonomy.

Wong, A.O. és Sixl-Daniell, K. (2017): Examining the Effectiveness of Corporate ELearning in Global Talent Management. International Journal of Advanced Corporate Learning (iJAC), 10 (2). doi:10/gf6cq5. 
Yazan, B. (2015): Three Approaches to Case Study Methods in Education: Yin, Merriam és Stake. The Qualitative Report, 20 (2): 134-152.

Yin, R.K. (1984): Case study research: design and methods. Sage Publications. (Google-Books-ID: bA1HAAAAMAAJ).

Y1lmaz, Y. (2012): Knowledge Management is e-learning practices. The Turkish Online Journal of Educational Technology, 11 (2): 150-155.

Yoo, S.J., Huang, W.-H. és Da Ye, L. (2012): The impact of employee's perception of organizational climate on their technology acceptance toward e-learning in South Korea., 4 (3): 359-378.

Zawacki-Richter, O. (2009): Research Areas in Distance Education: A Delphi Study. The International Review of Research in Open and Distributed Learning, 10 (3). doi:10/gf6crh.

Zhang, D. (2005): Interactive Multimedia-Based E-Learning: A Study of Effectiveness. American Journal of Distance Education, 19 (3): 149-162. doi:10/bzzt56.

Zhang, D. és Nunamaker, J.F. (2003): Powering E-Learning In the New Millennium: An Overview of E-Learning and Enabling Technology. Information Systems Frontiers, 5 (2): 207-218. doi:10/d4hvk7.

Zimmerman, J., Stolterman, E. és Forlizzi, J. (2010): An Analysis and Critique of Research through Design: towards a formalization of a research approach. proceedings of the 8th ACM conference on designing interactive systems, pp. 310-319.

Zolnai E. (2016): "Kvalitatav módszerek alkalmazási lehetőségei a szakdolgozat megírása során.” In Dr. R Fedor A. és Dr. Huszti É. (eds.): Kutatásmódszertani kézikönyv. Debrecen: Debreceni Egyetemi Kiadó. 


\section{MelléKLetek}

\subsection{Design Thinking}

A Design Thinking (DT), magyarul „design gondolkodás” vagy „tervezői gondolkodás” lényege, hogy a szolgáltatások és termékek (amelyek lehetnek folyamatok, kommunikációs megoldások stb.) ne csak funkcionálisan elégítsék ki az igényeket, hanem értékteremtő tervezést követően hosszútávú, emberközpontú megoldások legyenek. Ehhez pedig a menedzserek számára is fontos a tervezői (design) szemlélet, gondolkodás megértése, alkalmazása úgy szervezeti, mint stratégiai szinten (Boland és Collopy, 2004; Brown és Katz, 2011; Fehér, 2018). A DT és a design körüli gondolkodás már a 1960-as években megindult, leginkább mint kreatív technikák gyüjteménye problémák megoldására. A DT az 1980-as években, mint kognitív stílus hódított teret, és elsősorban rosszul strukturált problémák megoldására fókuszált. A kilencvenes években vált általános tervezési teóriává és célja a fent ismertetett „komisz problémák” (wicked problems) kezelése, amelyekkel kapcsolatosan már a '70-es években is megjelent gondolatok (Rittel és Webber, 1973). A 2010-es évekre már a szervezetekre és üzleti folyamtokra fókuszáltak a szerzők. A cél az innováció lett, mely a megoldhatatlan problémák helyett a szervezeti problémákat kezeli (Kimbell, 2011). A gyakorlatban ez azt jelenti, hogy egy IBM méretü nagyvállalat esetében a felhasználói élmény meghatározása és az üzleti stratégia között nincs különbség. Jon Kolko (2015) azonban rámutat egy másik fontos tartalmi kérdésre is: „... (a DT) segít a szervezeteknek komplex problémák átvágásban, és remek szemlélet az innovációhoz. Rendkívül jól müködik a jövő elképzelésében. De nem nyújt megfelelő eszközkészletet sem az optimális, sem az ésszerü müködtetéshez, sem a stabil üzletmenet fenntartásához.” (Kolko, 2015, p.7) Az e-learning tananyagfejlesztés esetében a DT szemlélet az „e-learning by design” gondolattal egészíthető ki, amelyet a 3.5 fejezetben bővebben kifejtek. A tudás és az ismeretek gyüjtése, felkutatása, rendszerezése fontos alapfeladatok, azonban a tudás reprezentációja, tanulásra érdemes formában történő átadása (vö. interaktív e-learning tananyagfejlesztés) kiemelten fontos üzleti cél is. A DT megjelenik az oktatásban is: számos kutatás során vizsgálták a hatását a mérnöki képzéstől (Dym et al., 2005), a fenntarthatóság oktatásán (Andrews, 2015) át, többek között a készségek fejlesztéséig (Noweski et al., 2012). A DT-t hiányzó láncszemként azonosították az elméleti és gyakorlati megvalósítás kapcsán a konstruktivista pedagógia szempontjából (Scheer et 
al., 2012). A konstruktivista megközelítés fontos elméleti alapokat jelent a kifejezetten elearning-et alkalmazó képzések esetében is. E kapcsolatok bővebb kifejtése túlmutat jelen disszertáció keretein, azonban a kapcsolódást fontosnak tartottam megemlíteni, hiszen a DT szemlélet ennek megfelelően gyakorlati megoldásokat (Koohang et al., 2009) mutat az e-learning tananyagfejlesztés szempontjából is. E gyakorlati megfontolások legfontosabb terepe a tananyagfejlesztés folyamatra is értelmezhető. Fontos, hogy a DT folyamat nem egymást szigorúan követő lépéseket definiál, hanem inkább egymáshoz vissza-visszatérő, folyamatos iterációban lévő tevékenységek rendszere. E rendszer három alapvető területet ölel fel: (1.) inspiráció, amely alapokat jelent a probléma és környezetének megismerésével kapcsolatosan; (2.) ötletelés, amely különböző megoldási lehetőségeket vizsgál, fejleszt és tesztel, pl. prototípusok készítésével és (3.) kivitelezés, amely során kialakul a végső (piaci) termék. Általánosan megfigyelhető, hogy egy adott probléma esetében a területek között folyamatos az átmenet: a DT nem egy lineáris folyamat (Brown, 2008). A Kineo - a világ egyik legnagyobb e-learning-es vállalkozása - az alábbi hét lépést azonosította a DT alkalmazása kapcsán:

1. „Meghatározás: probléma azonosítása, értelmezése.

2. Kutatás: probléma gyakorlati környezetben történő vizsgálata (pl. etnográfia), amely nem általánosan elterjedt a „klasszikus” oktatás tervezés során, általában amikor a megrendelő szakértője definiálja a problémát.

3. Ötletelés: különböző szakértők, különböző megoldási javaslatokat tesznek a megismert probléma kezelésére, legtöbb esetben brainstorming megoldások alkalmazásával.

4. Prototípus: a felmerült megoldási javaslatok egyszerü kipróbálásával pl. drótváztervekkel, egyszerü tananyagokkal. A prototípus ebben az esetben nem a végleges megoldás, hanem egy eszköz a megoldási javaslat erősségeinek és gyengeségeinek vizsgálatához.

5. Kiválasztás: annak a tervnek a kiválasztása, amely produkciós fázisba léphet.

6. Bevezetés: a kialakított terv ebben a stációban léphet egy tanulási eszközzé.

7. Tanulás: fontos a bevezetést követően értékelni és megvizsgálni a megoldás sikerességét, hatékonyságát. A DT szemléletben ezen értékelés elsősorban a végfelhasználóktól érkezik (akár kérdőívek, akár a tanulási adataik vizsgálatával).” (Kineo, 2013) 
A lehetséges lépéseket tekintve számos iskola létezik, pl. a „klasszikus” 5 lépéshez igazodó (Loizou, 2016; Milewska, 2017; Fehér és Varga, 2017), amely választ keres a „Ki?”, „Mit?”, „Miért?”, „Hogyan?, Mikor?” kérdésekre egy folyamaton belül, vagy 6 lépéses szemlélet (Pandey, 2018), amely nagyobb hangsúlyt helyez a kutatás és megértés fázisára. Azonban, amiben mindegyik szemlélet megegyezik, hogy nemlineáris folyamatként gondol az fejlesztésre, lehetőséget teremt a „dobozon kívüli gondolkodáshoz", továbbá felhasználó-centrikus, a felhasználó problémáihoz köti a lépéseket. E gondolkodásmód megjelenik az oktatás világában is, ahol a fentiekhez nagyon hasonló lépések vezetik a tanulókat a design szemlélet (lásd még: „design learning”, „design education”) jegyében (Scupelli, 2017). Úgy gondolom, hogy a DT nem jelenthet önmagában minden fejlesztési projekt esetében egyetlen igazodási pontot, az innováció utópisztikus megközelítését. A fent is leírt elvetemült problémák esetében ugyanakkor jó szemléletmód, és innovatív megközelítés lehet, amely jól illeszkedik a DS valós problémákra megoldásokat kereső szemléletéhez és az e-learning tananyagfejlesztés komplex világába.

\subsection{Design Science kutatás hármas tagolása}

Problémafelvetés: célom, hogy tudományos igényességgel összegyüjtsem az egyelőre szétszórt, akár rögzítésre sem került, kategorizáltalan problémákat. A gyüjtési folyamat és annak kiértékelése eredményezi a problémák azonosítását. A projektek általános lefolyása során a problémák folyamatosan merülnek fel, így a tudományos „problémafelvetés”, amely indító eleme a tudományos vizsgálódásnak, nem más, mint e felmerülő kérdések összefoglalása és elemzése. A jelen disszertáció alapvető kérdésfelvetését is ilyen szempontból indítottam. Többek között ez biztosítja a kutatás relevanciáját is, amely kiemelten fontos szempont (Offermann et al., 2009), hiszen közvetlen gyakorlati kapcsolódást biztosít a résztvevők számára, a várható eredményre fókuszál, és jövőbeli „kézzelfogható” eredmény kutatására ösztönöz (Benbasat és Zmud, 1999).

A problémák szisztematikus gyüjtése mellett ennek része a társterületek azonosítása is. A kutatáshoz az e-learning tananyagfejlesztéshez kapcsolódó területek felkutatása, rövid bemutatása alapozza meg az e-learning tananyagfejlesztési folyamatot.

Megoldás konstruálása: a legjobb gyakorlatok és meglévő megoldások tanulmányozása, a fejlesztési folyamatok tökéletesítése során alakul ki a termék. A megoldás konstruálása 
során kifejtésre kerül az e-learning tananyag fejlesztési folyamata, amely választ nyújt(hat) a problémákra. Offermann (2009) modellje is rámutat, hogy a megoldás konstruálása során kevés útmutató található, inkább általános irányok definiálhatók. Értékelés: a kutatási folyamat harmadik lépése a fentiek alapján kialakított termék, megoldás értékelése. Az értékelésnek számos formája és irányultsága lehetséges. Jelen disszertációban a fókuszt szakértői mélyinterjúk, továbbá szövegbányászati módszerrel e-learning alapú tanulás eredményeinek az átfogó vizsgálata jelentik. Az értékelés során szükségesnek látom megjelölni azokat a problémákat, amelyekre konkrét, gyakorlati választ ad az e-learning tananyagfejlesztés.

\subsection{A Design Science kutatás hármas kutatási ciklusa és ellenőrző listája}

A DSR hármas kutatási ciklusa:

1. Relevancia-ciklus (Relevance Cycle - ReC), amely összekapcsolja a környezetet és a DS tevékenységeket;

2. a Szigorúság-ciklus (Rigor Cycle - RiC), amely kapcsolatot teremt a kutatási tevékenység és a szakirodalom között;

3. Tervezési-ciklus (Design Cycle - DC), amely folyamatos figyelmet irányoz elő a termék elkészítése, értékelése és a kutatási folyamat között (Hevner, 2007).

A két módszertani tartalmat az alábbi ábra szemlélteti egységes szerkezetben, Helmuth és Steward kiegészítésével, amely kiemeli, hogy a „megoldhatatlan problémákat” (a 23. sz. ábrán „W”-vel jelölve) a Relevanciacikluson belül szükséges megtalálni (Hellmuth és Stewart, 2014). 


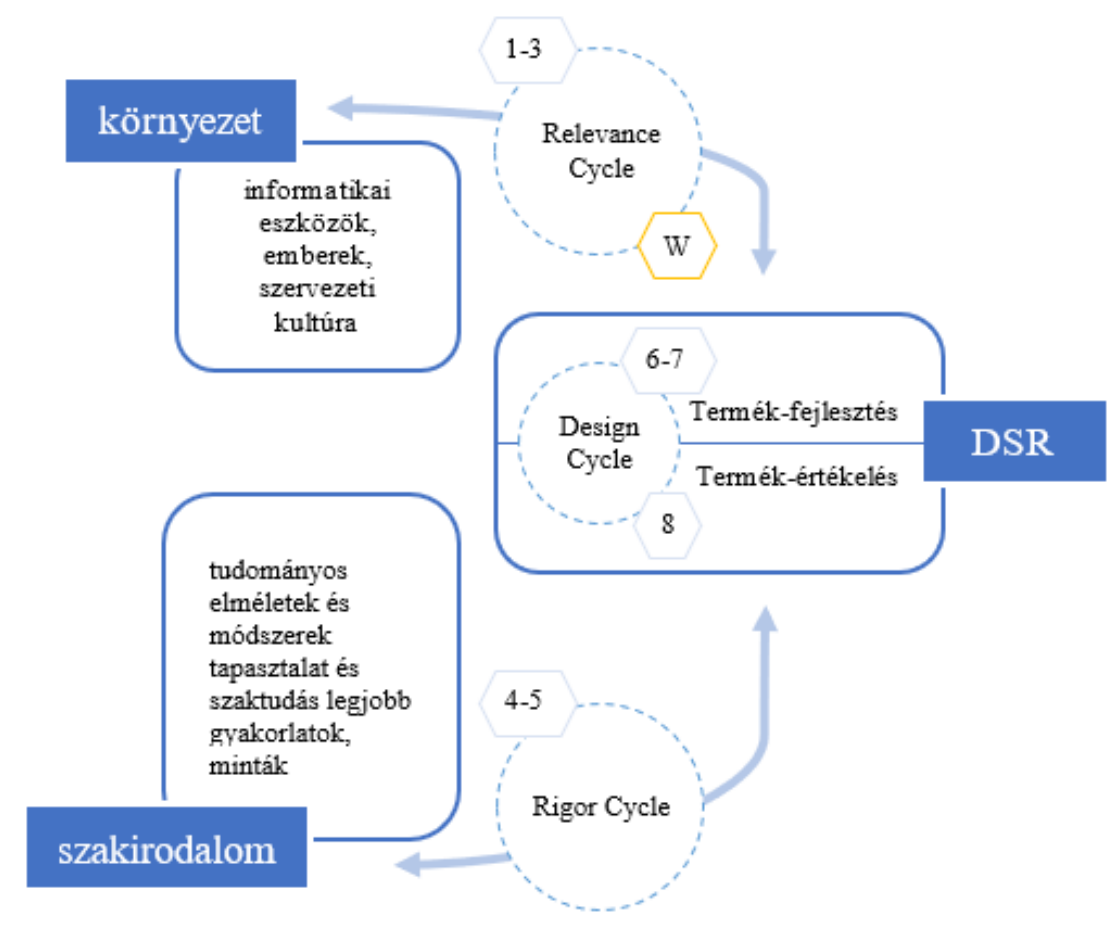

23. ábra - Design Scienc kutatási ciklusok és kapcsolódó ellenörzölista elemek (1-8-ig számozással) (Hevner és Chatterjee, 2010) alapján (saját ábra 2018)

A ReC elsősorban azt tartja szem előtt, hogy a vizsgálódás, kutatás valamilyen probléma vagy lehetőség alapján indul. Hevner (2007) kifejti, hogy a terepkutatások és a visszajelzések gyüjtése során kereshetjük a választ arra, hogy elértük-e a probléma megoldását, és amíg nem, addig az iterációk újra meg újra kell indulnia. A RiC biztosítja a kutatáshoz a korábbi tudományos vizsgálódások eredményét, hogy bizonyos legyen az újszerüség és ne rutinszerü fejlesztés valósuljon meg. Fontos, hogy a szigorú tudományos alap elsősorban a kreativitás kibontakozásának egyik lehetséges forrása legyen, nem pedig olyan elvárt minimum, amely nélkül nem értelmezhető egy DSR. Eredménynek tekinthető, ha korábbi teóriákat kiegészítünk vagy azokat a gyakorlatban alkalmazva elemezzük, és ezek alapján adunk vissza ismereteket mind a tudományos, mind a gyakorló közegnek. Az utolsó ciklus - a DC a központi eleme a kutatásnak: folyamatos iterációt jelent a termék konstruálása, értékelése és a termék továbbifejlesztése között. Az elvárásokat ehhez a ReC, míg az értékelés tudományát a ReC biztosítja. Továbbá Hevner (2007) felhívja a figyelmet, hogy fontos egyensúlyt tartani a konstruálás és a kiértékelés között, nem szerencsés, ha elbillen a kutatás az egyik vagy másik irányba.

A nyolc elemü ellenőrzőlista célja, hogy biztosítja az alapvető DS kutatási szempontok érvényesülését, és lehetőséget teremtsen a kutatás értékelésére. A szakirodalomban 
(Venable, 2010) megjelenik a ciklusok mellett a kutatás lefolytatásához és értékeléséhez kapcsolódó ellenőrző lista is, amely kérdései a következők (Hevner és Chatterjee, 2010).

1. „Mi a kutatási kérdés?

2. Mi a termék (artifact)? Hogy jelenik meg a termék?

3. Milyen tervezési folyamatot alkalmaz [a kutató] a termék létrehozásához?

4. Milyen tudományos elméleti alapokon nyugszik a termék és a tervezési folyamat?

5. Milyen értékelési történt a belső tervezési ciklus (design cycle) során, és milyen fejlesztéseket lehetett azonosítani e ciklusok során?

6. Milyen módon került sor a termék gyakorlati alkalmazására, és hogy tesztelték? Milyen mérési módszereket alkalmaztak [a kutatók] a termék használhatóságával és fejlődésével kapcsolatosan a megelőző verzióhoz képest?

7. Milyen új tudással bővült tudományos háttér és milyen formában?

8. [A kutató] megfelelően dolgozta fel a kutatási kérdéssel?” (Hevner és Chatterjee, 2010, p.20)

A Hevner által javasolt ellenőrző listával kapcsolatosan John R. Venable (2010) meglátásait, eredményeit emelném ki. Venable nem veti el teljes mértékben az ellenőrzőlista logikáját, de inkább egy kumulatív modellt javasol, amely úgy értékel egy DS kutatást, hogy nem csak összeveti az ellenőrző listával, és ez alapján von mérleget, hanem a részeredményeket is fontosnak tartja. Azt a szerző is elismeri, hogy ebben az esetben a kutatás tudományos értéke alacsonyabb, de vitatja, hogy minden kutatás esetben a legmagasabban értékelt folyóiratok szintjét kellene mérvadónak tekinteni.

\subsection{Az action research és a case study stratégiák összehasonlítása}

Alapvetően, és önmeghatározásuk szerint, mindkét kvalitatív módszertani megközelítés alapjaiban támogatja a részvételen alapuló és empirikus, releváns témákat vizsgáló kutatásokat. Miközben, ahogy Coghlan (2002) leírja, nem törekednek univerzális tudás létrehozására, de adott problémákra szabott keretet adnak vizsgálódásra (Blichfeldt és Andersen, 2006). Az AR esetében a cselekvő részvevők végzik a kutatást, kvázi saját maguk javítása, céljuk a probléma megoldása. A CS estében egy olyan empirikus kutatásról beszélünk, amely esetben kontextus és megfigyelt projekt határai összemosódnak (Sagor, 2000; Yin, 1984). Sok esetben az esettanulmányt készítő kutató a „légy a falon” típusú megközelítésben vesz csak részt egy adott projektben és nem aktív 
alakítója a folyamatoknak. A részvételen alapuló esettanulmány alapú kutatás esetében azonban egy bizonyos környezet, egy bizonyos időre vonatkozó megfigyelése esetében a résztvevő kutató is lehet a megfigyelés tárgya (Baskerville, 1997).

A két stratégia közötti különbségeket az alábbi táblázatban foglalom össze.

Szempont

A kutatás célja

Kutató részvétele

Kutatási szigor

Időtáv

Esetek száma

Eredmény publikálása

Elméleti keretek és

általánosítás

\section{Action Research}

Probléma megoldása

Aktív résztvevő

Magas szintü

Hosszú

Több

Gyakorlati résztvevők felé is

Alacsony szintü

\section{Case Study}

Probléma megfigyelése

Passzív résztvevő, vagy csak megfigyelö

Alacsony szintű

Egyszeri

Egy (kevés)

Akadémiai közönség számára

Magas szintü

23. táblázat - Action Research és Case Study módszertanok összehasonlitása (Baskerville, 1997; Blichfeldt és Andersen, 2006) alapján (saját táblázat 2019)

\subsection{AntConc táblázat}

\begin{tabular}{|rrrrll} 
Rank & Freq. & Freq (L) & Freq (R) & Stat & Collocation \\
$\mathbf{1}$ & 7 & 4 & 3 & 5.47450 & personalization \\
$\mathbf{2}$ & 18 & 14 & 4 & 5.37764 & adaptive \\
$\mathbf{3}$ & 40 & 14 & 26 & 4.88055 & system \\
$\mathbf{4}$ & 8 & 7 & 1 & 4.76026 & implementing \\
$\mathbf{5}$ & 9 & 5 & 4 & 4.58915 & intelligent \\
$\mathbf{6}$ & 9 & 3 & 6 & 4.51515 & platform \\
$\mathbf{7}$ & 8 & 3 & 5 & 4.49722 & role \\
$\mathbf{8}$ & 8 & 4 & 4 & 4.49722 & cloud \\
$\mathbf{9}$ & 7 & 5 & 2 & 4.47450 & interactive \\
$\mathbf{1 0}$ & 17 & 11 & 6 & 4.46921 & quality \\
$\mathbf{1 1}$ & 23 & 5 & 18 & 4.46279 & environment \\
$\mathbf{1 2}$ & 9 & 4 & 5 & 4.37764 & integration \\
$\mathbf{1 3}$ & 76 & 27 & 49 & 4.33011 & content \\
$\mathbf{1 4}$ & 18 & 4 & 14 & 4.31351 & systems \\
$\mathbf{1 5}$ & 8 & 2 & 6 & 4.27483 & ict \\
$\mathbf{1 6}$ & 12 & 5 & 7 & 4.16465 & by \\
$\mathbf{1 7}$ & 7 & 5 & 2 & 4.15258 & multimedia \\
$\mathbf{1 8}$ & 10 & 3 & 7 & 4.13110 & information \\
$\mathbf{1 9}$ & 12 & 10 & 2 & 4.12283 & evaluation \\
$\mathbf{2 0}$ & 17 & 7 & 10 & 4.11076 & model \\
$\mathbf{2 1}$ & 8 & 3 & 5 & 3.96671 & inte \\
$\mathbf{2 2}$ & 16 & 7 & 9 & 3.96671 & ease \\
\hline & & & & & \\
\hline
\end{tabular}




\begin{tabular}{|c|c|c|c|c|c|}
\hline 23 & 51 & 32 & 19 & 3.96453 & an \\
\hline 24 & 7 & 4 & 3 & 3.95094 & effectiveness \\
\hline 25 & 7 & 4 & 3 & 3.95094 & developing \\
\hline 26 & 15 & 7 & 8 & 3.93018 & through \\
\hline 27 & 13 & 6 & 7 & 3.87574 & framework \\
\hline 28 & 10 & 5 & 5 & 3.85979 & ehallenges \\
\hline 29 & 24 & 13 & 41 & 3.77638 & using \\
\hline 30 & 12 & 9 & 3 & 3.72855 & management \\
\hline 31 & 37 & 15 & 22 & 3.72686 & development \\
\hline 32 & 18 & 6 & 12 & 3.70779 & material \\
\hline 33 & 107 & 59 & 48 & 3.67052 & for \\
\hline 34 & 155 & 73 & 82 & 3.65325 & in \\
\hline 35 & 16 & 13 & 3 & 3.64478 & approach \\
\hline 36 & 7 & 1 & 6 & 3.61652 & environments \\
\hline 37 & 44 & 22 & 22 & 3.61088 & based \\
\hline 38 & 12 & 5 & 7 & 3.60826 & higher \\
\hline 39 & 17 & 9 & 8 & 3.60486 & medical \\
\hline 40 & 8 & 6 & $z$ & 3.57969 & impact \\
\hline 41 & 44 & 17 & 27 & 3.52667 & en \\
\hline 42 & 50 & 28 & 22 & 3.52310 & education \\
\hline 43 & 15 & 2 & 13 & 3.50795 & technology \\
\hline 44 & 165 & 122 & 43 & 3.48465 & өf \\
\hline 45 & 9 & 4 & 5 & 3.44476 & knowledge \\
\hline 46 & 7 & 1 & 6 & 3.34522 & language \\
\hline 47 & 17 & 9 & 8 & 3.29518 & study \\
\hline 48 & 41 & 4 & 7 & 3.26860 & review \\
\hline 49 & 7 & 1 & 6 & 3.26505 & mobilelearning \\
\hline 50 & 9 & 3 & 6 & 3.22236 & from \\
\hline 51 & 93 & 50 & 43 & 3.22047 & the \\
\hline 52 & 95 & 33 & 62 & 3.21464 & $\mathbf{a}$ \\
\hline 53 & 26 & 13 & 13 & 3.20772 & students \\
\hline 54 & 7 & 4 & 3 & 3.18910 & courses \\
\hline 55 & 20 & 13 & 7 & 3.18172 & * \\
\hline 56 & 8 & 5 & 3 & 3.17530 & science \\
\hline 57 & 38 & 14 & 24 & 3.14029 & te \\
\hline 58 & 14 & 7 & 7 & 3.11695 & design \\
\hline 59 & 116 & 51 & 65 & 3.10939 & and \\
\hline 60 & 14 & 6 & 8 & 3.08219 & student \\
\hline 61 & 41 & 9 & $z$ & 3.06049 & analysis \\
\hline 62 & 7 & 1 & 6 & 2.95094 & teachers \\
\hline 63 & 10 & 4 & 6 & 2.94468 & educational \\
\hline 64 & 7 & 4 & 3 & 2.91994 & research \\
\hline 65 & 7 & $z$ & 5 & 2.85979 & as \\
\hline 66 & 8 & 3 & 5 & 2.80917 & epen \\
\hline 67 & 13 & 9 & 4 & 2.75288 & online \\
\hline 68 & 14 & 6 & 8 & 2.71962 & teaching \\
\hline 69 & 7 & 1 & 6 & 2.66715 & course \\
\hline 70 & 9 & 7 & 2 & 2.64725 & blended \\
\hline
\end{tabular}




$\begin{array}{rrrrrl}\mathbf{7 1} & 9 & 5 & 4 & 2.62762 & \text { e } \\ \mathbf{7 2} & 14 & 9 & 5 & 2.47450 & \text { curriculum } \\ \mathbf{7 3} & 9 & 4 & 5 & 2.46203 & \text { with } \\ 74 & 69 & 35 & 25 & 2.38421 & \text { learning } \\ \mathbf{7 5} & 34 & 17 & 17 & 2.37523 & \text { elearning }\end{array}$

\subsection{VOSViewer táblázat}

\begin{tabular}{|c|c|c|c|c|c|c|c|}
\hline label & $\mathbf{x}$ & $\mathbf{y}$ & $\underset{r}{\text { cluste }}$ & $\begin{array}{c}\text { Link } \\
\mathrm{S}\end{array}$ & $\begin{array}{c}\text { Total link } \\
\text { strength }\end{array}$ & $\begin{array}{c}\text { Occurrenc } \\
\text { es }\end{array}$ & $\begin{array}{l}\text { Avg. pub. } \\
\text { year }\end{array}$ \\
\hline acceptance & $\begin{array}{l}- \\
0.349 \\
3\end{array}$ & $\begin{array}{l}0.498 \\
2\end{array}$ & 1 & 22 & $35^{\circ}$ & 25 & 2014.88 \\
\hline achievement & $\begin{array}{l}0.864 \\
3\end{array}$ & $\begin{array}{l}- \\
0.165 \\
8\end{array}$ & 5 & 25 & 48 & 20 & 2014.55 \\
\hline activity & $\begin{array}{l}- \\
0.526 \\
3\end{array}$ & -0.102 & 8 & 16 & 18 & 16 & 2015 \\
\hline adaptive e & $\begin{array}{l}- \\
0.989 \\
3\end{array}$ & $\begin{array}{l}- \\
0.481 \\
9\end{array}$ & 1 & 15 & 35 & 18 & 2014.9444 \\
\hline adoption & $\begin{array}{l}0.150 \\
2\end{array}$ & $\begin{array}{l}0.949 \\
4\end{array}$ & 6 & 13 & 18 & 14 & 2015 \\
\hline application & $\begin{array}{l}- \\
0.322 \\
8\end{array}$ & $\begin{array}{l}- \\
0.743 \\
7\end{array}$ & 2 & 23 & 31 & 35 & 2014.8286 \\
\hline assessment & -0.209 & $\begin{array}{l}- \\
0.945 \\
1\end{array}$ & 2 & 12 & 14 & 13 & 2014.4615 \\
\hline attitude & $\begin{array}{l}0.413 \\
5\end{array}$ & $\begin{array}{l}- \\
0.269 \\
2\end{array}$ & 3 & 16 & 22 & 14 & 2014.7143 \\
\hline augmented reality & $\begin{array}{l}0.412 \\
5\end{array}$ & $\begin{array}{l}- \\
0.584 \\
3\end{array}$ & 2 & 15 & 22 & 14 & 2014.8571 \\
\hline blended learning & $\begin{array}{l}0.186 \\
9\end{array}$ & $\begin{array}{l}0.192 \\
9\end{array}$ & 3 & 15 & 20 & 21 & 2014.9048 \\
\hline challenge & $\begin{array}{l}- \\
0.658 \\
5\end{array}$ & $\begin{array}{l}0.238 \\
8\end{array}$ & 1 & 16 & 17 & 19 & 2014.7895 \\
\hline classroom & $\begin{array}{l}0.204 \\
1\end{array}$ & -0.493 & 5 & 23 & 34 & 30 & 2014.6 \\
\hline cloud & $\begin{array}{l}- \\
0.713 \\
6\end{array}$ & $\begin{array}{l}0.751 \\
7\end{array}$ & 1 & 7 & 10 & 11 & 2014.5455 \\
\hline cloud computing & $\begin{array}{l}- \\
2.028\end{array}$ & $\begin{array}{l}0.231 \\
4\end{array}$ & 1 & 7 & 8 & 8 & 2014.625 \\
\hline community & $\begin{array}{l}0.018 \\
3\end{array}$ & $\begin{array}{l}0.687 \\
5\end{array}$ & 6 & 12 & 16 & 13 & 2014.9231 \\
\hline content & $\begin{array}{l}- \\
0.162 \\
5\end{array}$ & $\begin{array}{l}- \\
0.413 \\
8\end{array}$ & 2 & 35 & 69 & 71 & 2015.5634 \\
\hline context & $\begin{array}{l}- \\
0.675 \\
4\end{array}$ & $\begin{array}{l}0.051 \\
4\end{array}$ & 8 & 9 & 13 & 14 & 2015 \\
\hline country & $\begin{array}{l}0.096 \\
4\end{array}$ & $\begin{array}{l}1.178 \\
6\end{array}$ & 6 & 9 & 12 & 10 & 2015 \\
\hline curriculum & $\begin{array}{l}- \\
0.667 \\
1\end{array}$ & $\begin{array}{l}0.469 \\
4\end{array}$ & 6 & 17 & 24 & 37 & 2015.4595 \\
\hline
\end{tabular}




\begin{tabular}{|c|c|c|c|c|c|c|c|}
\hline e learning content & $\begin{array}{l}- \\
0.430 \\
4\end{array}$ & $\begin{array}{l}- \\
1.166 \\
1\end{array}$ & 2 & 5 & 6 & 8 & 2015.625 \\
\hline e learning environment & $\begin{array}{l}- \\
0.064 \\
2\end{array}$ & $\begin{array}{l}- \\
0.234 \\
3\end{array}$ & 1 & 12 & 18 & 18 & 2014.7222 \\
\hline e learning system & $\begin{array}{l}- \\
0.112 \\
7\end{array}$ & $\begin{array}{l}- \\
1.256 \\
6\end{array}$ & 1 & 3 & 3 & 12 & 2015.25 \\
\hline educational data mining & $\begin{array}{l}- \\
1.068 \\
4\end{array}$ & $\begin{array}{l}0.270 \\
2\end{array}$ & 1 & 4 & 4 & 8 & 2014.375 \\
\hline effect & $\begin{array}{l}0.791 \\
9\end{array}$ & $\begin{array}{l}- \\
0.024 \\
9\end{array}$ & 4 & 38 & 101 & 67 & 2014.9104 \\
\hline effectiveness & $\begin{array}{l}0.642 \\
1\end{array}$ & $\begin{array}{l}- \\
0.167 \\
5\end{array}$ & 2 & 21 & 33 & 30 & 2014.6667 \\
\hline engagement & $\begin{array}{l}- \\
0.176 \\
6\end{array}$ & $\begin{array}{l}- \\
4\end{array}$ & 7 & 19 & 30 & 20 & 2014.65 \\
\hline evaluation & $\begin{array}{l}- \\
0.038 \\
4\end{array}$ & $\begin{array}{l}- \\
0.381 \\
8\end{array}$ & 2 & 29 & 40 & 27 & 2015.1111 \\
\hline evidence & $\begin{array}{l}- \\
0.204 \\
9\end{array}$ & $\begin{array}{l}0.096 \\
9\end{array}$ & 7 & 19 & 31 & 20 & 2014.8 \\
\hline experience & 0.301 & $\begin{array}{l}0.157 \\
6\end{array}$ & 5 & 35 & 57 & 32 & 2014.9688 \\
\hline flipped classroom & $\begin{array}{l}0.767 \\
4\end{array}$ & $\begin{array}{l}0.096 \\
6\end{array}$ & 4 & 13 & 13 & 12 & 2015.4167 \\
\hline focus & $\begin{array}{l}0.473 \\
1\end{array}$ & $\begin{array}{l}- \\
0.656 \\
5\end{array}$ & 3 & 6 & 9 & 7 & 2015.4286 \\
\hline framework & $\begin{array}{l}- \\
0.428 \\
1\end{array}$ & $\begin{array}{l}0.502 \\
8\end{array}$ & 6 & 31 & 47 & 52 & 2014.8269 \\
\hline future & $\begin{array}{l}- \\
0.539 \\
4\end{array}$ & $\begin{array}{l}0.335 \\
5\end{array}$ & 8 & 4 & 5 & 10 & 2015 \\
\hline game & $\begin{array}{l}0.242 \\
2\end{array}$ & $\begin{array}{l}- \\
0.587 \\
4\end{array}$ & 7 & 27 & 59 & 38 & 2014.8947 \\
\hline gamification & $\begin{array}{l}- \\
0.919 \\
6\end{array}$ & $\begin{array}{l}- \\
0.746 \\
4\end{array}$ & 8 & 7 & 13 & 13 & 2014.7692 \\
\hline ict & $\begin{array}{l}- \\
0.374 \\
6\end{array}$ & $\begin{array}{l}- \\
0.060 \\
9\end{array}$ & 3 & 9 & 9 & 11 & 2014.5455 \\
\hline implementation & $\begin{array}{l}- \\
0.117 \\
7\end{array}$ & $\begin{array}{l}- \\
0.002 \\
3\end{array}$ & 7 & 22 & 24 & 24 & 2015 \\
\hline influence & $\begin{array}{l}- \\
0.627 \\
2\end{array}$ & $\begin{array}{l}- \\
0.245 \\
2\end{array}$ & 7 & 11 & 14 & 10 & 2014.4 \\
\hline instruction & $\begin{array}{l}0.749 \\
4\end{array}$ & $\begin{array}{l}- \\
0.586 \\
9\end{array}$ & 2 & 12 & 17 & 14 & 2015.1429 \\
\hline integration & -0.487 & $\begin{array}{l}0.345 \\
4\end{array}$ & 2 & 17 & 21 & 22 & 2014.7273 \\
\hline interaction & $\begin{array}{l}0.333 \\
6\end{array}$ & $\begin{array}{l}- \\
0.332 \\
7\end{array}$ & 2 & 20 & 28 & 17 & 2014.5882 \\
\hline knowledge & $\begin{array}{l}0.034 \\
9\end{array}$ & $\begin{array}{l}0.258 \\
5\end{array}$ & 3 & 28 & 44 & 30 & 2015.0667 \\
\hline
\end{tabular}




\begin{tabular}{|c|c|c|c|c|c|c|c|}
\hline language & $\begin{array}{l}- \\
0.122 \\
5\end{array}$ & $\begin{array}{l}- \\
1.120 \\
9\end{array}$ & 2 & 11 & 20 & 14 & 2014.9286 \\
\hline learner & $\begin{array}{l}0.072 \\
6\end{array}$ & $\begin{array}{l}- \\
0.776 \\
8\end{array}$ & 1 & 18 & 22 & 17 & 2015 \\
\hline literature & $\begin{array}{l}- \\
0.454 \\
2\end{array}$ & -0.134 & 3 & 5 & 5 & 12 & 2015.0833 \\
\hline management system & $\begin{array}{l}0.472 \\
2\end{array}$ & $\begin{array}{l}0.196 \\
5\end{array}$ & 4 & 19 & 32 & 33 & 2014.4848 \\
\hline medical student & $\begin{array}{l}0.612 \\
7\end{array}$ & $\begin{array}{l}0.804 \\
6\end{array}$ & 5 & 10 & 11 & 10 & 2015.1 \\
\hline meta analysis & $\begin{array}{l}1.330 \\
6\end{array}$ & -0.208 & 4 & 17 & 31 & 17 & 2014.7647 \\
\hline mobile & -0.06 & $\begin{array}{l}- \\
0.027 \\
7\end{array}$ & 7 & 3 & 3 & 7 & 2014.7143 \\
\hline mobile device & 1.764 & $\begin{array}{l}- \\
0.113 \\
6\end{array}$ & 4 & 4 & 8 & 7 & 2015.1429 \\
\hline mobile learning & $\begin{array}{l}0.354 \\
7\end{array}$ & $\begin{array}{l}0.707 \\
6\end{array}$ & 6 & 13 & 19 & 22 & 2014.6818 \\
\hline mooc & $\begin{array}{l}0.140 \\
2\end{array}$ & $\begin{array}{l}0.629 \\
7\end{array}$ & 5 & 13 & 19 & 21 & 2014.7143 \\
\hline moocs & $\begin{array}{l}- \\
0.604 \\
1\end{array}$ & $\begin{array}{l}0.334 \\
3\end{array}$ & 8 & 7 & 8 & 11 & 2015.0909 \\
\hline moodle & $\begin{array}{l}- \\
0.462 \\
3\end{array}$ & $\begin{array}{l}0.471 \\
6\end{array}$ & 1 & 16 & 19 & 11 & 2014.5455 \\
\hline motivation & $\begin{array}{l}- \\
0.269 \\
7\end{array}$ & $\begin{array}{l}- \\
0.310 \\
9\end{array}$ & 8 & 27 & 49 & 26 & 2014.8846 \\
\hline multimedium & 0.945 & $\begin{array}{l}- \\
0.856 \\
8\end{array}$ & 2 & 5 & 7 & 7 & 2015.4286 \\
\hline object & $\begin{array}{l}0.274 \\
4\end{array}$ & $\begin{array}{l}0.848 \\
4\end{array}$ & 5 & 7 & 9 & 11 & 2014.6364 \\
\hline online & $\begin{array}{l}0.229 \\
1\end{array}$ & $\begin{array}{l}0.068 \\
9\end{array}$ & 2 & 12 & 15 & 13 & 2014.3077 \\
\hline $\begin{array}{l}\text { online learning } \\
\text { environment }\end{array}$ & $\begin{array}{l}- \\
0.106 \\
2\end{array}$ & $\begin{array}{l}- \\
0.734 \\
2\end{array}$ & 2 & 8 & 8 & 8 & 2014.625 \\
\hline ontology & -0.541 & $\begin{array}{l}- \\
0.222 \\
1\end{array}$ & 3 & 11 & 15 & 15 & 2014.9333 \\
\hline opportunity & $\begin{array}{l}- \\
0.871 \\
7\end{array}$ & $\begin{array}{l}- \\
0.216 \\
9\end{array}$ & 1 & 11 & 15 & 9 & 2015.6667 \\
\hline performance & $\begin{array}{l}0.951 \\
2\end{array}$ & $\begin{array}{l}- \\
0.016 \\
5\end{array}$ & 4 & 24 & 49 & 36 & 2014.9167 \\
\hline platform & $\begin{array}{l}- \\
0.336 \\
1\end{array}$ & $\begin{array}{l}0.300 \\
2\end{array}$ & 1 & 15 & 17 & 19 & 2014.8947 \\
\hline practice & $\begin{array}{l}- \\
0.402 \\
3\end{array}$ & $\begin{array}{l}0.777 \\
1\end{array}$ & 6 & 16 & 26 & 27 & 2014.7037 \\
\hline problem & -0.953 & $\begin{array}{l}- \\
0.269 \\
1\end{array}$ & 1 & 15 & 21 & 20 & 2015.15 \\
\hline $\begin{array}{l}\text { professional } \\
\text { development }\end{array}$ & -0.746 & $\begin{array}{l}0.894 \\
9\end{array}$ & 6 & 6 & 7 & 8 & 2014.875 \\
\hline quality & $\begin{array}{l}0.303 \\
9\end{array}$ & $\begin{array}{l}0.521 \\
6\end{array}$ & 5 & 19 & 30 & 20 & 2014.8 \\
\hline
\end{tabular}




\begin{tabular}{|c|c|c|c|c|c|c|c|}
\hline recommender system & $\begin{array}{l}- \\
0.332 \\
6\end{array}$ & $\begin{array}{l}- \\
0.353 \\
6\end{array}$ & 3 & 8 & 11 & 19 & 2015.6316 \\
\hline relationship & $\begin{array}{l}1.338 \\
4\end{array}$ & $\begin{array}{l}0.505 \\
3\end{array}$ & 5 & 8 & 16 & 9 & 2015 \\
\hline satisfaction & $\begin{array}{l}0.439 \\
2\end{array}$ & $\begin{array}{l}0.116 \\
4\end{array}$ & 4 & 28 & 50 & 31 & 2014.9032 \\
\hline serious game & 0.218 & $\begin{array}{l}- \\
0.295 \\
7\end{array}$ & 7 & 5 & 8 & 8 & 2015 \\
\hline social medium & $\begin{array}{l}0.039 \\
4\end{array}$ & $\begin{array}{l}1.151 \\
5\end{array}$ & 6 & 7 & 7 & 12 & 2014.9167 \\
\hline state & $\begin{array}{l}- \\
0.831 \\
4\end{array}$ & 0.163 & 1 & 9 & 10 & 9 & 2014.6667 \\
\hline strategy & $\begin{array}{l}0.295 \\
2\end{array}$ & $\begin{array}{l}0.562 \\
1\end{array}$ & 5 & 16 & 20 & 18 & 2015 \\
\hline student satisfaction & $\begin{array}{l}0.594 \\
7\end{array}$ & $\begin{array}{l}- \\
0.412 \\
7\end{array}$ & 2 & 7 & 8 & 7 & 2014.7143 \\
\hline students perception & $\begin{array}{l}1.069 \\
5\end{array}$ & $\begin{array}{l}0.493 \\
8\end{array}$ & 4 & 9 & 11 & 8 & 2014.875 \\
\hline style & $\begin{array}{l}- \\
0.264 \\
5\end{array}$ & -0.665 & 1 & 23 & 35 & 21 & 2014.8571 \\
\hline success & $\begin{array}{l}0.377 \\
3\end{array}$ & $\begin{array}{l}- \\
0.176 \\
1\end{array}$ & 7 & 10 & 13 & 11 & 2015.2727 \\
\hline system & $\begin{array}{l}- \\
0.452 \\
4\end{array}$ & $\begin{array}{l}- \\
0.221 \\
9\end{array}$ & 1 & 43 & 92 & 80 & 2014.95 \\
\hline systematic review & $\begin{array}{l}0.539 \\
1\end{array}$ & $\begin{array}{l}- \\
0.300 \\
1\end{array}$ & 3 & 16 & 28 & 20 & 2014.95 \\
\hline teacher & $\begin{array}{l}- \\
0.170 \\
8\end{array}$ & $\begin{array}{l}0.307 \\
5\end{array}$ & 8 & 13 & 13 & 13 & 2014.8462 \\
\hline tool & $\begin{array}{l}0.375 \\
6\end{array}$ & $\begin{array}{l}0.248 \\
2\end{array}$ & 4 & 25 & 28 & 25 & 2014.72 \\
\hline training & $\begin{array}{l}0.102 \\
9\end{array}$ & $\begin{array}{l}- \\
0.002 \\
8\end{array}$ & 7 & 19 & 22 & 23 & 2014.8696 \\
\hline university & $\begin{array}{l}- \\
0.063 \\
5\end{array}$ & $\begin{array}{l}0.644 \\
9\end{array}$ & 1 & 25 & 33 & 27 & 2014.7037 \\
\hline use & $\begin{array}{l}0.544 \\
7\end{array}$ & $\begin{array}{l}0.319 \\
3\end{array}$ & 4 & 32 & 72 & 52 & 2014.8077 \\
\hline web & $\begin{array}{l}- \\
0.131 \\
2\end{array}$ & $\begin{array}{l}0.429 \\
5\end{array}$ & 3 & 18 & 26 & 26 & 2014.5385 \\
\hline
\end{tabular}

\subsection{Kutatásba bevont projektek részletes bemutatása}

Az egyes projektek elemzése során, szisztematikusan, az alábbi pontokat vizsgáltam meg:

a) Mi volt az adott projekt célkitüzése? Milyen nagyvállalati problémát lehet azonosítani, amelyre megoldást kínál a fejlesztés?

b) A tananyagfejlesztés során milyen megfigyelt, összegyüjtött gyakorlati feladatok valósultak meg? 
c) A fejlesztés során milyen problémák, nehézségek és lehetőségek adódtak technológiai, módszertani, projekt- és tudásmenedzsment szempontból?

d) Az azonosított problémákra, lehetőségekre milyen választ/reakciót adott a projektcsapat a fejlesztés során? Ezek a reakciók/válaszok milyen eredménnyel zárultak?

e) Milyen a tananyagfejlesztési folyamattal kapcsolatos releváns tapasztalatok szürhetők le? Egy-egy szóval milyen új elem került be az 5C tananyagfejlesztési folyamatba a projekt által?

f) Milyen értékelést kapott az adott fejlesztési projekt? Adott-e választ az eredeti nagyvállalati problémára a fejlesztés eredményterméke?

g) Köthető-e szervezeti innováció a projekthez?

\subsubsection{Irodai programokhoz tananyagok fejlesztése}

A projekt alapvető célja volt, hogy nagyvállalati ügyfelek számára készítsen online elérhető, önálló tanulásra alkalmas e-learning tananyagot. Az addig kizárólag jelenléti képzéseken oktatott, igen népszerü irodai programcsomag használatát így tantermi alkalmak nélkül, vagy lényegesen kevesebb jelenléti alkalommal tudták elsajátítani a cégek alkalmazottai. Az alapvető nagyvállalati probléma több részből tevődött össze az irodai programcsomag ismeretével kapcsolatosan:

1. A képzésre egyfelől szükségük volt az új belépők alacsony előképzettsége miatt, másfelől az egyedi, vállalatspecifikus ismeretek átadása kapcsán. Továbbá a szoftver új verzióinak és új funkcióival kapcsolatos információkat is szükséges volt időről-időre átadni.

2. A klasszikus jelenléti alkalmak során hosszú időre kellett kivenni a kollégákat a munkából, alacsony volt a képzések hatékonysága (pl. nem jegyzeteltek, lemaradtak, eltérő tudással ültek be stb.) és több ezer fő esetében komoly logisztikai problémát is okozott a megfelelö mennyiségü terem, gép és oktatói kapacitás előteremtése.

3. A fentiek okán ráadásul igen költséges is egy-egy szoftverátállás oktatása a nagyvállalat több ezer fős alkalmazotti köre számára.

A fejlesztés során a Microsoft klasszikus irodai programcsaládjának az Office-nak négy szoftveréhez (Word, Excel, PowerPoint, Outlook) készült e-learning tananyag több 
szinten és több nyelven. (A több nyelv jelen esetben nem a tananyagok eltérö nyelvét jelentette, hanem a szoftverek eltérő nyelvét.)

A fejlesztési folyamatba kifejezetten a gyártási, tananyag-szerkesztési szakaszban vettem részt, mint projektvezető. A csapatunk feladata volt, hogy előregyártott tananyagelemekből (képek, leírások, videók, szimulációk) forgatókönyv alapján állítsuk össze a végleges tananyagokat. A legnagyobb kihívást a gyártás szervezése és a megfelelö számú szakember munkába állítása jelentette két okból kifolyólag: 1. nagyon nagy mennyiségü tananyag elkészítés volt a feladat: több, mint 150 modult kellett összeállítani (1-1 modul kb. 2 óra tanulási időnek megfelelő tartalmat fedett le), 2. a feladat méretéhez képest igen rövid idő alatt. Ezek mellett kisebb technológiai problémák is felmerültek a szimulációk lejátszása és időzítése kapcsán. A projektmenedzsment nehézségeket elsősorban szoros felügyelettel, és több szintű gyártástámogatási szakértők bevonásával (gyártásvezetői szerepkör) kerültek kiküszöbölésre. A gyártás-szervezési feladatokat pedig egy „manufaktúra rendszer” felállításával lehetett kezelni, amely kialakításával alacsony szintre lehetett szorítani a hibák számát, és fel lehetett gyorsítani a gyártás folyamatát. E manufaktúra rendszer technológiai oldalról előre gyártott html kódok (snippletek) alkalmazását jelentette, szervezési oldalról pedig - a klasszikus gyártási feladatokhoz hasonlóan - az egyes munkafolyamatok aprólékos szétválasztását. A projekt értékelése kapcsán egyértelmüvé vált, hogy e manufaktúra rendszer csak az ilyen jellegü nagy mennyiségü, azonos alkotóelemekből álló, kreativitást nélkülöző tananyagok esetében alkalmazható. Ám ezek esetében rendkívül hatékony és jó megoldás.

\subsubsection{Jogszabályok és szervezetek ismertetése}

A projekt alapvető célja szerint a sok irodával rendelkező szervezet alapinformációkat átadó képzéseit kívánta elektronikus csatornára terelni, a „klasszikusnak” tekinthető elearning által elvárt elönyök reményében: idő- és költségmegtakarítás. A képzést szervező osztály az országos jelenlétből eredő képzésszervezés és utaztatási logisztikai problémákat kívánta orvosolni a fejlesztés által. Továbbá a szervezet vizsgáztatási kötelezettségeit kívánta egyszerüsíteni a tananyag elsajátítását bizonyító adatok felhasználása mellett (lásd teljesítettségi riportok).

Mivel a tananyagok nagy részét jogszabályismeret adta, így a meglévő tartalmak módszertani feldolgozására nem volt lehetőség: a projektben a forgatókönyvírás fázisában lehetett „,belépni”. Ez elsősorban formai forgatókönyvírást jelentett, vagyis a 
feldolgozni kívánt tartalomhoz csak alaki, technológiai (pl. illusztrációt választottunk, egyszerü interakció típusokat készítettünk, alapszintü animációkat fogalmaztunk meg stb.) irányból nyúlhattunk. Majd e forgatókönyvek megírását követően klasszikus gyártási folyamat vette kezdetét. Az alapszintü informatikai infrastruktúra okán a legegyszerübb html alapú tartalmak készültek, és kisebb mennyiségben - az akkori technológiának megfelelően - Flash alapú interaktív elemeket mellett kizárólag illusztrációs multimédiás (egyszerübb képek, folyamatábrák stb.) elemek implementáltunk az anyagokba. A nehézségét elsősorban a kifejezetten száraz (jogszabályi) tartalom jelentette, amely alaki feldolgozása is igen limitált kreativitási lehetőséget jelentett, tartalmi feldolgozásra nem adott lehetőséget a megbízó. Ennek köszönhetően kizárólag az e-learning tananyag alapvető lehetőségei érvényesülhettek (pl. távolról is elérhető). Technológiai oldalról pedig egy elavult szoftveres környezeten (pl. régi böngésző verzió, régi operációs rendszerek, hangkártya vagy hangszóró hiánya stb.) is futtatható tananyagkeret összeállítása okozott technológiai problémát. Míg a módszertani nehézségeket elsősorban gazdag illusztrációs és animációkat tartalmazó interaktív tartalmak beemelésével támogattuk meg, valós elmozdulás a „tankönyv digitalizációjához" képest nem valósult meg. Technológiai oldalról sikerült megvalósítani azt a lejtászómotort, amely a legelavultabb környezetekben is helyt állt, illetve az alapvetően html kódokra alapozó gyártás esetében ismét lehetőség volt ún. gyorskódok alkalmazására, amely egyszerre segítette az egysége formai megjelenést, és a gyártás sebességének fokozását. Ez utóbbira elsősorban azért is szükség volt, mert az előzetes tervektől eltérően a forrásanyagot, amelyet az egyes területi szakértők készítettek, csúszások mellett kaptuk kézhez, miközben a véghatáridő nem volt módosítható. Ez utóbbi helyzet ismételten előhívhatta az előzőekben ismertetett manufaktúra típusú gyártási metódust, annak minden előnyével (gyors, hatékony gyártás) és hátrányával (alacsony módszertani szint, nem igazán képernyőre tervezett tartalmak). Folyamatszintü tapasztalatként azonosítható a projekt alapján, hogy a sok szakértős forrásanyagszerzés esetében is kulcskérdés azonosítani egy vezető szerzőt, aki felelős a határidők és a szakmai tartalom tekintetében. A kifejezetten egyszerü e-learninges tananyagoknak tekinthető végeredmények dacára (vagy éppen ezért) a tananyagok nagy sikert értek el a tanulók körében. Ez elsősorban annak volt köszönhető, hogy a jelenléti alkalmak nehézségeihez képest már elve komoly könnyebbséget jelentettek a digitális 
tananyagok, másodsorban pedig a célközönség kor-összetételéhez és informatikai képességihez megfelelő szintü tananyagból tanulhattak.

\subsubsection{Továbbképzési rendszer}

Jelen elemzésben egy kreditpontot biztosító továbbképzési rendszert új, e-learning alapokra helyező komplex projekt egyik pillérének, az új e-learning tananyagok fejlesztésének a szakmai kutatása áll. A projekt célja egyfelől a teljes képzési paletta tananyaginak e-learning feldolgozása volt, és kizárólag online elérhető oktatási anyagok létrehozása. Az alapvető képzési problémát e projekt esetében (is) a sok-sok, általában kis létszámú, de országos lefedettségü célközönség elérése, utaztatása jelentette. Ez egyik oldalról komoly logisztikai feladatokat, másik oldalról pedig költséges képzéseket jelentett (mind a sok-sok jelenléti alkalom, mind pedig az utazásokhoz kapcsolódó munkaidő kiesés okán). A fentiekben röviden összefoglalt célok eléréséhez több területen dolgoztak együtt szakemberek, fejlesztők. Ebben az összefoglalóban a tananyagfejlesztés aspektusára koncentrálok. Az egyik távlati cél az volt, hogy a 2015-re már sok szempontból kutatott és igen hatékonyan müködő MOOC típusú képzésekhez hasonló tanulási, tanítási környezetet alakítsunk ki a résztvevők számára, elsősorban videós tartalmak bemutatásával. A feladat két nagyobb részből tevődött össze:

1. Az egyik egy olyan tananyaglejátszó-motor kialakítása, amely megfelel a projekt által meghatározott módszertani igényeknek (pl. kérdésekkel megszakított videós tartalom, letölthető szakanyag tartalom, videók feliratozása stb.).

2. A másik pedig magának a tananyagoknak a gyártási folyamatának kialakítása, automatizálása.

Magáról a tananyag technikai részleteiről és a fejlesztési folyamatról részletes publikációnk jelent meg (Orbán és Balkányi, 2015), amely pontosan bemutatja és taglalja azokat a módszertani és technológiai elemeket, amelyeket végigevettünk a projekt sikeres elvégzéséhez. Jelen elemzésben az ehhez kapcsolódó következtetéseket kívánom bemutatni. A tananyagmotor kialakítása egy klasszikus informatikai fejlesztési projektnek tekinthető, hiszen a módszertani szakértőktől érkező ,üzleti igények” alapján készült el az a funkciókban igen gazdag lejátszó, amely arculati keretet is jelentett a tananyagok számára. Míg a gyártási folyamat egyik legjelentősebb kihívása az volt, hogy kevesebb, mint háromnegyed év alatt kellett több, mint 100 tananyaghoz kapcsolódó több száz videós tartalmat előállítani. Egy-egy videós anyag forrása négy fő komponensből 
tevődött össze: 1. stúdióban rögzített, ún. greenbox felvétel az előadóról; 2. az előadó mögé bevágásra került előadás; 3. az elhangzottak szöveges leirata; 4. megszakító kérdések és válaszok. A fentiekhez forrásanyagként sorban egy videófájl, egy ppt fájl, egy szöveges dokumentum és egy táblázat készült el. Ilyen mennyiségü tananyag gyártása, a rendelkezésre álló idő alatt kizárólag „kézi” szerkesztés által, nem lett volna megvalósítható. Ezzel kapcsolatosa a projekt során több prototípus készült el, tesztelve egyfelől a módszertani és technológiai fejlesztéseket, másfelől pedig felmérve az egységre eső gyártási igényt (szakértők és gyártási idő oldalról egyaránt). A korábban már jól bevált manufaktúra típusú gyártási metódus elsősorban emberi erőforrások hiányában nem lett volna megvalósítható.

Az első feladatokhoz (tananyag motor fejlesztése) kapcsolódóan a sikeres fejlesztést a prototípus fejlesztések, és ezek folyamatos interaktív javítása jelentette, agilis projektvezetési és programozási szempontok szerint. Míg a második feladatkör esetében (gyártás) egy olyan folyamatot alakított ki a csapat, amely segítségével több számítógépen párhuzamosan volt lehetőség futtatni azt a programot, amely a fent említett elemekből, minimális emberi beavatkozás mellett, összeállította a tananyagokat: összeillesztette a stúdiófelvételeket a ppt-böl html alapokon animált elöadásokkal, majd a videók alapján időzítette a legépelt szövegkönyveket is, amelye később feliratként lehetett olvasni az egyes tananyagok esetében (illetve indexálás követően e szövegek jelentették a beépített kereső kulcsszavait is). Továbbá e folyamat során az automata rendszer illesztette a megfelelő helyekre a különböző típusú megszakító kérdéseket is. Ehhez hasonló innovatív tananyaggyártási megoldásra nem találtam egyéb, akár nemzetközi példát sem. A fentiek alapján világossá vált, hogy az e-learning tananyagfejlesztés esetében is megvalósítható olyan megoldás, amely „ipari” mennyiségben képes átlagos minőségü, de magas módszertani elvárásoknak megfelelő tartalmakat előállítani. Ehhez szükséges volt egyfelől az automatizálható gyártási folyamatot lefejlesztő szakértők beemelése a projektbe, másfelöl a folyamat és a tartalom standardizálására, a kapcsolódó sablonok rigorózus alkalmazására. E második kikötés azonban ugyancsak fontos megállapítás lett, hiszen függetlenül az igen széles funkcionalitással bíró lejátszótól, és a hatalmas mennyiségü anyagtól, tartalmi oldalon igen komoly kihívásokkal küzdöttek a tartalmak. Ennek egy része a tömeggyártásból eredő egységesített módszertani eszközkészlet alkalmazása (pl. mindig ugyanaz az öt típus feladat szakította meg a videókat, az összes tananyag igen hasonló arculati világgal 
készült el, az egyedi kerettörténeket teljes hiánya), a másik tényező pedig az alacsony előadói színvonal (I4.). Módszertani oldalról ugyanis teljesen egyértelművé vált, hogy videós tananyagelőadó bárkiből nem vállhat. A fentiek mellett a fejlesztés kifejezetten sikeresnek mondható, egyfelől a tanulói értékelések alapján is, másfelől pedig azért is, mert a teljes szakmai tartalmat sikerült egy projekt keretein belül feldolgozni. Ezen a ponton fontos megjegyezni, hogy az ilyen típusú tartalmak (pl. sok jogszabályértelmezés) esetében a tartalom folyamatos hatályosítása elengedhetetlen feladat, illetve ennek örvén számos lehetőség adódik a tömeges gyártásból eredő hátrányok folyamatos fejlesztéséhez. A projekt utóélete más irányba formálta e tananyagokat.

\subsubsection{Közszféra szervezete számára szakmai és szemléletformáló tananyagai}

A projekt egyik célja olyan újszerü e-learning tananyagok fejlesztése volt, amelyek túlmutattak a megbízó által már ismert egyszerü, szöveges anyagok formai és módszertani keretein. Másfelől pedig az alapvető cél volt szakmai továbbképzést nyújtani távoktatás keretén belül a résztvevők számára. Az induló fejlesztési igényt (megoldandó problémát) a kötelező vizsgázási előírás, a résztvevők nagy létszáma és a szervezetek országos jelenléte jelentette, amely az ismert szervezési és utazási problémákat jelentette. A fejlesztés során az adott anyag koncepciójának kidolgozásától kezdve, a forgatókönyvek készítésén át, a teljes gyártási és átadási folyamat a feladat része volt, ami lehetőséget teremtett, hogy módszertani szempontból is megfelelő, és technológiai újításokat is tartalmazó fejlesztés valósuljon meg. A projekt lefolyása során az egyik nehézséget a forrásanyagok (szakanyagok) igen eltérő (pl. sok szerző, más-más stílusok stb.) minősége okozta. Illetve a tudásanyag sok esetben kaotikus formában állt csak rendelkezésre. Ennek megfelelően sok időt igényelt a forrásanyagok feldolgozása, a szakértőkkel folytatott egyeztetés. A projekt során több témában készült 1-1, egymástól eltérő technológiai és módszertani szemléletü tananyag, jellemzően a technológiai korlátok és téma feldolgozhatósága kapcsán. Az anyagok több modulból (tananyagegységből) álltak, és mindegyik estében a célközönségről elmondható volt, hogy igen heterogén társaság számára kellett formát és tartalmat fejleszteni mind életkor, mind informatikai felkészültség szempontjából. Az anyagok közül volt, amelyet kifejezetten alacsony IT infrastruktúrára kellett már az első pillanattól kezdve tervezni (elavult böngészők, operációs rendszerek, alacsony sávszélesség stb.). Míg a többi téma kapcsán, a technológiai oldalról biztosabbnak tűnő háttér okán, multimédiás tartalomban gazdagabb tartalom készült, három szempont szerint: 1. a tanulási élmény fokozása 
érdekében; 2. a témák között voltak olyanok, amelyek esetében kifejezetten segítette a feldolgozást a videós formátum; 3. a játékos és magasan interaktív tartalmak az elmélyülést és a figyelem fenntartását célozták. A projektek értékelése során azonban kiderül, hogy a (tervezetten) ,jobb” IT eszközök sem minden esetben jelenteken valójában teljes körben megfelelő infrastruktúrát. Így nehézségekbe ütközött több olyan - a szakmai szempontokat és módszertani megoldásokat, amelytől egy tananyag ,jó”, vagyis tanuló- és tartalomközpontú e-learning anyag -elérhetővé tétele is. Ettől az utólagos értékeléstől függetlenül minden anyag esetében törekedtünk, hogy keverjük a különböző formákat, hogy az eltérő tanulási szokásokkal rendelkező résztvevők mindegyike számára nyújtsanak az anyagok lehetőséget az elmélyült és hatékony tanuláshoz. Feljegyzendő újítás volt a tananyagokhoz illeszkedő ún. tananyag indítópult (dashboard) kialakítása, amely egyfelől bemutatta az anyag egyedi alaptörténetét (amelyhez kapcsolódhattak később az arculati elemek, példák, illusztrációk, feladatok stb.), másfelől pedig összefogta az eltérő tartalmi elemeket és vezette a tanulót.

A később használatba kerülő anyagok - amennyiben eltekintünk a technológiai buktatóktól - úgy kifejezetten pozitív fogadtatást kaptak, hiszen olyan formai és módszertani új elemeket ismertek meg általa a részvevők. E lehetőségek addig ismeretlenek voltak számukra, és a többnyire szöveges e-learning tartalmakhoz szokott, és ettől (értehető módon) erős negatív attitüddel rendelkező tanulók is meglátták a kötelező képzéseken túl is a tanulási, önfejlesztési lehetőséget. A projekt rámutatott egyfelől a prototípusfejlesztés fontosságára, másfelől pedig a sokkal szisztematikusabban gyüjtött, és részletesebb technológiai kritériumokat is tárgyaló ellenőrzőlisták fontosságára.

\subsubsection{Területspecifikus alap- és termékismeretek átadása}

A projekt alapvető célja volt, hogy a meglévő több napos tantermi képzést teljes egészében online csatornára terelje át. Emellett célként definiáltuk még a tananyag általános szakmai, tartalmi felülvizsgálatát (frissesség, hatályosság stb.), valamint a kifejezetten képernyő előtt való tanulásra átdolgozását. Partnerünk az alábbi problémákra kereste a választ az e-learning tananyagok fejlesztésével: 1. országos lefedettségű képzést kellett biztosítania; 2. a képzésre jelentkezők száma nem volt egyenletes; 3. nehezen volt mérhető a képzések hatékonysága; 4. vizsgáztatás papír alapon zajlott (lassú volt a kiértékelés és az adminisztráció); 5. sokan lemorzsolódtak, de nem volt világos, hogy mikor, miért és hogy lehetne ez ellen tenni. 
A projektben a koncepcióalkotástól vettünk részt, amely jelen esetben egy több napos mühelymunkát jelentett a képzés szervezői, szakértőivel (pl. trénerek) és szakmai irányítóival. E közös alkalmak során építőelemeire bontottuk az egész képzést, és teljes mértékben a képernyő előtti tanulás szempontjai szerint építettük újra. Fontos volt, hogy egy jól követhető, később akár bővíthető kerettörténetet készítettünk, amely visszaköszönt módszertanilag, kinézetét tekintve a teljes tananyagfejlesztés során. A koncepció kidolgozásakor kifejezetten törekedtünk arra, hogy elsődleges szempont legyen a tanulók tanulási élménye, és a heterogén célcsoport minden tagja megtalálja a számára befogadható technológiai és módszertani megoldásokat. A koncepcióalkotást követően a téma szakértői segítségével elkészültek a forgatókönyvek, és prototípusok az egyes interaktív és multimédiás tartalmak tekintetében. A szisztematikus előkészítő munkának köszönhetően - bár komoly gyártási feladatot jelentett - gördülékeny gyártás zajlott, amelyet kisebb technológiai problémák ugyan megakasztottak, de összességében nem voltak kiemelkedő nehézségek azonosíthatók. Számos interaktív, játékos megoldást implementáltunk a tananyagban, valamint nagy mennyiségü videós tananyag is gazdagította a képzést. Minden témát a kerettörténetnek megfelelően, és az ezzel kapcsolatos tematika mentén dolgoztunk fel. Továbbá a vállalat (igen egyedi) arculati elvárásaihoz is maximálisan illeszkedő kinézetet készítettünk.

A megrendelővel folytatott szoros közös munka, és az általa is a projekthez biztosított komoly erőforrások kifejezetten a tananyagok előnyére váltak: komplex, a kor technológiai és módszertani elvárásainak megfelelő, látványos képzést alakítottunk ki. Egy fontosabb kritikus pontot már a fejlesztés során azonosítani lehetett, ez pedig a képzés kizárólag online csatornára történő átterelése, amelyhez partnerünk ragaszkodott. A tananyag értékelése kapcsán vált világosság, hogy érdemes lett volna, ha csak kisebb részben is, de bizonyos tartalmi elemek tekintetében kevert képzési formát megvalósítani, akár egyéb digitális eszközök pl. online fogadóóra bevezetésével.

\subsubsection{Készségfejlesztő tananyagok}

Elsősorban nagyvállalati ügyfelek számára, kifejezetten alapozó szinten, több témában készültek el készségfejlesztő tananyagok, hiszen komoly piaci érdeklődés mutatkozott mind munkavállalói, mind képzésfejlesztési oldalról a kifejezetten készségfejlesztő (pl. tárgyalástechnika, kommunikáció, prezentációs technikák, projektmenedzsment stb.) digitális tananyagok iránt. Másodsorban pedig e fejlesztés lehetőséget nyújtott arra, hogy számos projekt- és tanulásmódszertani és technológiai elképzelést kipróbáljunk, és ennek 
kapcsán vizsgáljak egy teljes egészében a saját elvek alkalmazása mellett készülő tananyagok esetében. Természetesen időbeli és anyagi korlátjai voltak a fejlesztésnek, de számos olyan szempontot figyelembe lehetett venni, amelyet egy megrendelésre készülő fejlesztés esetében nem lehet, és így elkészíthető volt a tanuló- és tartalomközpontú elearning tananyag. A fejlesztés célja tehát, egy heterogén, de az adott területen akár még alap tudással sem, vagy csak alacsony szintủ szakmai tudással rendelkező nagyvállalati munkavállalók számára, kb. 2-3 órás tanulási idővel kalkuláló, 8 témát feldolgozó készségfejlesztő tananyagcsalád fejlesztése. A problémák, amelyekre reflektálni kívánt a fejlesztés az alábbi elemekből állt:

1. Új belépők: Sok és igen eltérő kompetenciákkal rendelkeznek az új belépő (pl. pályakezdő), vagy területet váltó munkavállaló, akik számára az alapvető információk átadása, a kollégák „szintre hozás” jelentős szervezési feladat és költséges.

2. Tréninghatékonyság: A készségfejlesztés legtöbb esetben jelenléti alkalmak során valósul meg, amelynek első - akár több órás - része az alapinformációk, szakszavak, definíciók átadásával telik. Ez a nem túl hatékony, legtöbbször frontális elem fölöslegesnek és időpazarlónak (ezáltal költségesnek) tekinthető. Ezt helyettesítheti egy egységes alaptudást megcélzó tananyag, amely által az alapvető ismeretek elsajátíthatók egyéni tanulással. Amennyiben kapcsolódik hozzá jelenléti alkalom (pl. tréning), úgy ott több lehetőség marad a célzott (egyéni és/vagy csoportos) fejlesztésekre.

3. Mérési nehézség: Nehezen mérhető a tréningek hatékonysága, és ezt jól ki lehet egészíteni digitális eszközökkel.

4. Fiatal kollégák elvárásai: Elsősorban a Z-generáció képviselői el is várják az egyéni fejlesztési lehetőségeket, leginkább olyan területeken, amelyek általános kompetenciákat fejleszt, és nem kizárólag az adott cég számára fontos (pl. belső szoftver használatának ismeret stb.), hanem a munkavállalót, mint egyént is fejleszti (ilyenek legtöbbször a készségfejlesztő témák). Fontos a fókuszált figyelem fenntartása, a ,videóklipszerü tartalom” (I1.). 


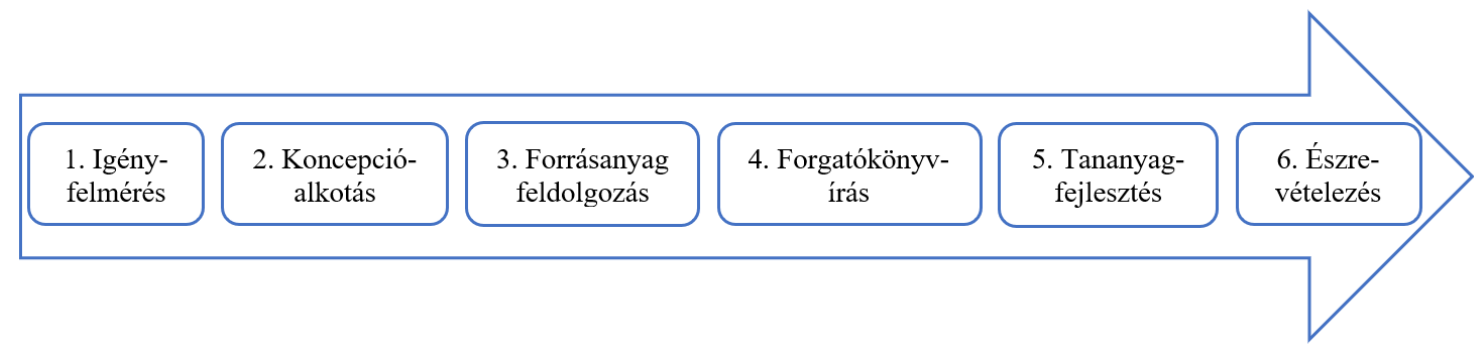

24. ábra - Alkalmazott tananyagfejlesztési folyamat (saját ábra 2019)

A saját fejlesztés kapcsán a feladatok sorát a teljes tananyagfejlesztési folyamat (lásd 24. ábra) lefedése jelentette: a koncepció kialakítása, amely elsősorban a fent részletezett célkitüzések mentén, a fent részletezett problémák kezelésére reflektál. Másodsorban pedig tartalmazza mindazokat a módszertani és technológiai elemeket, amelyek definiálják a tanuló- és tartalomközpontú e-learning tananyagot. A forrásanyagfeldolgozás során egyetemi környezetből érkező, szakmai anyagokból indult ki a fejlesztés, melyek nem az „e-learning by design” szemléletben készültek, és ez jelentett is később nehézségeket (I2.). A forgatókönyvírás során olyan a tréningekben és e-learning tananyagok fejlesztésében is jártas szakértők készítettek el, akik a tananyagot már a megfelelő szemlélet szerint készítették. Ez alapján tervezték meg az egységes kerettörténetet, amely nem csak tananyagok, de tananyagcsaládon belül is végig kíséri azokat a tanulókat, akik akár több témával is találkoznak. Továbbá számos multimédiás (pl. videók, narrált szituációs feladatok) és interaktív (fogd és vidd típusú tudásmélyítő feladatok, kérdőívek stb.) elemet terveztek a tananyaghoz. A gyártás során lehetőség volt alkalmazni, és tesztelni azokat a projektmódszertani (prototípus készítés, ellenőrzőlisták alkalmazása) és gyártástechnológiai (előre definiált interakciók, egységes narráció- és videófelvételi technikák stb.) megoldásokat, amelyek mind-mind támogatták a célként megfogalmazott tanuló- és tartalomközpontú e-learning tananyag fejlesztését. E projekt esetében az is megvalósult természetesen az észrevételezési szakaszban, amelyben reflektálni lehetett a fejlesztés egészére, és javítani a kisebb technikai hibákat. Ekkor volt lehetőség kiegészíteni a tartalmat még olyan elemekkel, amelyek tovább erősítették koncepciót.

A fejlesztés nehézségei - belső jellege okán - a projekt időbeli tervezésével és menedzsmentjével kapcsolatosan merültek fel, egyfelől a belső erőforrások allokációja, másfelől a külső szakértők bevonásával összefüggésben. A tervezéssel több időt kellett volna tölteni (I2.). 
A projekt alapján egyértelmüvé vált, hogy az a standardizált és dokumentált gyártási folyamat, amely támogatta a tananyagfejlesztést, jól müködik, és egyszerre nyújt gyorsaságot, relatív alacsony hibaszámokat és mind formai, mind módszertani oldalról is igényes, a tanuló- és tartalomközpontú e-learning tananyag kritériumainak megfelelő tartalmak előállítását támogatja. Ebből a nézőpontból a fejlesztés sikeresnek mondható.

\subsection{Mélyinterjúk bemutatása}

A disszertáció majd mindegyik kutatási kérdésével kapcsolatosan szükségesnek láttam, hogy szakértők véleményével, tapasztalatával egészítsem ki a saját megfigyeléseket, vagy konkrét vizsgálatokat. A szakértőket - a korábban már részletezett - félig strukturált interjú környezetben kérdeztem meg. Három területről merítettem: 1. nagyvállalatok képzési területén dolgozó vezető munkatársak; 2. „e-learning szakértők”, akik az elmúlt évek vagy évtizedek során rengeteg tananyagfejlesztési projektben vettek részt elsősorban módszertani és elméleti oldalról. 3. az e-learning tananyagfejlesztést a gyakorlatban müvelö szakértők.

Az interjúalanyok egy része anonimitást kért, mert jellemző volt, hogy a beszélgetés kapcsán titoktartási kötelezettségük alá eső kérdések is szóba kerültek.

A részvevőkkel félig strukturált mélyinterjúkat készítettem, amelyek általában 60-120 percesek voltak. A módszertannak megfelelően nem minden kérdést tettem fel minden résztvevőnek, illetve nem kötött sorrendben haladtunk, de az alábbi kérdéseket jártuk körül:

a) Milyen általános problémákkal találkozik a képzési/emberi erőforrás területen?

b) Mi a meglátása, milyen szervezti vagy egyéni problémákat, kihívásokat lehet megoldani kifejezetten a tananyagfejlesztés által?

c) Miért merült fel Ön szerint, hogy e-learning tananyagot fejlesszen a szervezete?

d) Milyen problémák, nehézségek jellemeznek egy-egy tananyagfejlesztési folyamatot a szervezet részéről?

e) Milyen az Ön által idealizált e-learning tananyagfejlesztési folyamat? Ön, mint szakértő/megbízó/stb. mely ponton tud/kíván/stb. becsatlakozni?

f) Hogyan értékelnek egy e-learning-es tanuláson alapuló képzést?

g) Milyen kulcsrésztvevőket azonosít egy-egy tananyagfejlesztési folyamatban?

h) Mi a tapasztalata a különböző tananyagtípusok tekintetében? Mely típusok népszerüek, és miért? 
i) Van-e tapasztalata valamilyen elégedettségméréssel és eredményességméréssel kapcsolatosan? Amennyiben igen, úgy mi az?

j) Alkalmaznak-e Önök valamilyen vállalati tudásmenedzsment megoldást? Amennyiben igen, úgy van-e kapcsolódási pont a digitális tananyagokkal?

k) Milyen eredményeket tud azonosítani egy-egy tananyagfejlesztés által?

1) Az Ön meglátása szerint, a fejlesztés konkrét eredménytermékén (pl. tananyag) túl van-e hatása egy-egy ilyen projektnek a nagyvállalat müködésére, fejlődésére?

m) Mi a tapasztalata a kifejezetten képernyőre készített tananyagok tekintetében?

n) Mennyire tartja fontosnak a tananyagok megjelenését, kinézetét?

o) Van-e tapasztalata Z-generációs munkavállalók tanulási szokásaival kapcsolatosan?

Az interjúk eredményeit a disszertáció különböző pontjain mutatom be, mindenhol a releváns kérdéshez kapcsolódóan.

Az interjúalanyok bemutatása (több alany név nélkül kívánt megjelenni titoktartási kötelezettsége okán):

Ssz. Név

I1. Csillik Olga

I2. Csuvár Fruzsina

I3. Iszlai Ádám

I4. Mongyi

Zsolt

I5. Nagy

Zoltán

I6. név nélkül budapesti tréning cég vezetője közigazgatási területen e-learning

szakértő

\section{Munkahely, pozíció}

felsőoktatási intézmény

tanárképzéssel és digitális tanulással

e-learning fejlesztő kisvállalkozás

projektvezetője

telekommunikációs vállalat

munkatársa

e-learning fejlesztő kisvállalkozás

projektvezetője foglalkozó központ munkatársa

\section{Kapcsolódás és tapasztalat}

felnőttképzésekkel kapcsolatos

módszertani szakértelem és gyakorlati ismeretek

sok éves e-learning tananyagfejlesztői tapasztalat, mint gyártásvezető, projektvezető és e-learning szakértő nagyvállalat képzési területén szerzett több éves tapasztalat sok éves e-learning tananyagfejlesztői tapasztalat, mint gyártásvezető, projektvezető és e-learning szakértő számos nagy szervezetek számára készülő e-learning fejlesztések módszertani szakértője sok éves tapasztalat a képzési és fejlesztési terület kiszolgálásával kapcsolatosan 


\begin{tabular}{|c|c|c|c|}
\hline I7. & név nélkül & $\begin{array}{l}\text { multinacionális vegyipari vállalat } \\
\text { munkatársa }\end{array}$ & $\begin{array}{l}\text { új belépők és munka- és tüzvédelmi } \\
\text { képzésekkel kapcsolatos széleskörü } \\
\text { tapasztalatok }\end{array}$ \\
\hline I8. & név nélkül & $\begin{array}{l}\text { multinacionális vállalat képzésért } \\
\text { felelős vezetője }\end{array}$ & $\begin{array}{l}\text { területspecifikus és értékesítési hálózat } \\
\text { képzésével kapcsolatos tapasztalat }\end{array}$ \\
\hline I9. & név nélkül & japán autóipari vállalat munkatársa & $\begin{array}{l}\text { képzési területért felelős munkatársként } \\
\text { felnőttképzési területen szerzett sok éves } \\
\text { tapasztalat }\end{array}$ \\
\hline I10. & név nélkül & $\begin{array}{l}\text { multinacionális vállalat képzési és } \\
\text { fejlesztési főosztály vezetője }\end{array}$ & $\begin{array}{l}\text { sok éves tapasztalat képzési területért } \\
\text { felelős vezetőként nagyvállalati } \\
\text { környezetben }\end{array}$ \\
\hline I11. & $\begin{array}{l}\text { Orbán } \\
\text { Hajnalka }\end{array}$ & $\begin{array}{l}\text { korábban e-learning fejlesztésekkel } \\
\text { foglalkozó vállalat projektvezetője és } \\
\text { szakértője }\end{array}$ & $\begin{array}{l}\text { sok éves e-learning tananyagfejlesztői } \\
\text { tapasztalat, mint projektvezető és e- } \\
\text { learning szakértő }\end{array}$ \\
\hline I12. & $\begin{array}{l}\text { Szani } \\
\text { Ferenc }\end{array}$ & Infotér szakértő & $\begin{array}{l}\text { számos közigazgatási fejlesztésben e- } \\
\text { learning fejlesztések módszertani } \\
\text { szakértője }\end{array}$ \\
\hline
\end{tabular}

\subsection{Tananyagfejlesztés folyamatának részei részletesen}

\section{Megismerés, feltárás}

$\begin{array}{ll}\text { Szempont } & \text { Leírás } \\ \text { Gyakorlati } & \text { Megfigyelhető, hogy e lépést nagyon röviden, és leegyszerüsítve jelenik meg a } \\ \text { megvalósulás } & \text { fejlesztések során. Kevés a résztvevők széles körét bevonó, alapos előzetes } \\ & \text { kutatás. Inkább a vezetői elvárások és célok összefoglalása, definiálása jelenik } \\ & \text { meg. } \\ \text { Részfolyamatok } & \text { Legfontosabb eleme, hogy a fejlesztéshez megértsük a problémákat, amelyeket } \\ & \text { sok esetben szisztematikus kutatással lehet megismerni (lásd interjúk, } \\ & \text { fókuszcsoportos beszélgetések stb.). } \\ & \text { Ellenőrzőlista alapján a fejlesztési igények rögzítése támogatható, ez írásbeli, } \\ & \text { jobb esetben személyes egyeztetés(ek) során alakul ki a megbízói oldal aktív és } \\ & \text { minél széleskörü közremüködésével. További részfolyamat az igények } \\ & \text { strukturálása, összefoglalása, valamint a projektalapító dokumentáció } \\ & \text { létrehozása. } \\ & \text { megbízó képviselő(i), tanulók (munkatársak), projektvezető, e-learning szakértő } \\ \text { (opc.), gyártásvezető (opc.) }\end{array}$

${ }^{36}$ Szakmai felelős aláhúzva 


$\begin{array}{ll}\text { Átfutás idő } & 1-2 \text { hét } \\ \text { Kockázatok } & \text { Nincs lehetőség (erőforrás vagy idő kapcsán) a problémák pontos feltárása, a } \\ & \text { szervezet megismerésére. } \\ & \text { Megbízó oldaláról nem egyértelműek a fejlesztési igények, ebben az esetben } \\ & \text { tanácsadás keretében érdemes közösen gondolkozni a képzési célok alapján. } \\ & \text { A képzés tárgyát képező rendszer, termék stb. még nem készült el. Kisebb } \\ & \text { egységekre érdemes felbontani a teljes fejlesztési folyamatot. Itt segíthetnek a } \\ & \text { modern projektmenedzsment szemléletek agilis nézőpontjai. } \\ & \text { Későbbi kulcsfejlesztési elemet nem azonosítottunk az igények felmérése során. } \\ & \text { Ellenőrző listát szükséges kiegészíteni, és lehetőség szerint ismét a fejlesztés } \\ & \text { általános folyamatát érdemes más szemlélet szerint folytatni. } \\ & \text { igényfelmérő előzetes átadása, eredménytermék: projekt alapító dokumentum. } \\ \text { A képzési cél alapján mind módszertani, mind technológiai szempontból } \\ \text { nincsenek vagy nagyon kevés „fehér folt” azonosítható, vagyis jól definiáltak a } \\ \text { problémák és világos a tananyagfejlesztés célja, hatóköre, általános menete, } \\ \text { lefolyása. }\end{array}$

\section{Megértés, földre hozás}

Szempont

Gyakorlati

megvalósulás

\section{Leírás}

Az előző szakasz függvényében alakul e pont gyakorlati megvalósulása. Jellemző, hogy a vezetői célok túlsúlyba kerülnek, amely a projektek sikerességét kevésbé, a tananyagok minőségét viszont befolyásolják. További jellegzetesség, hogy a megrendelöi oldal ezen a ponton kevés támpontot ad.

Részfolyamatok

A fejlesztés nagyságától és komplexitásától függően alapvetően a pár órás egyeztetéstől a több napos mühelymunkáig terjedhet időben fejlesztési koncepció kidolgozása.

E munkában szükséges bevonni az összes - a későbbi folyamatokban érintett terület - szakértőt. Itt kiemelten fontos a több körös egyeztetés. A tervek pontosítása követően kerül véglegesítésre és jóváhagyásra a megbízó által a tananyag koncepciója. További kiemelendő a vezetői, és nem csak a szakértői jóváhagyás fontossága (I11.), amely jó esetben támaszkodik utóbbira.

A forrásfeldolgozás jelentheti a megbízótól érkező szakanyagok részletes áttekintését, feldolgozását, ami megegyezik a szakmai anyag vásárlásával. De ebbe a szakaszba értendő akár új szakmai tartalom létrehozása. Fontos, hogy a korábban kialakított forrásanyaggal szemben megfogalmazott elvárásoknak megfelelö anyagokkal dolgozzunk. 
A feldolgozás során sokszor alacsony szinten strukturált tartalmaknak szükséges új, az e-learning by design szemlélet és a koncepció alapján átrendezni, újra értelmezni. Sok esetben ebben a fázisban egyeztetés történik a forrásanyag szerzőjével, az adott szakma képviselőjével, akitől - adott esetben - további forrásanyagok kérhetők.

Amennyiben új tartalom fejlesztésére kerül a sor, úgy abban az esetben eleve lehetőség van és szükséges is az e-learning by design elveit érvényesíteni. Ez sok esetben a szerzők (egyéni vagy csoportos) felkészítését és módszertani támogatását is jelenti (pl. gondolattérkép technika alkalmazása, korábbi tananyagokból minták bemutatása stb.).

A megfelelő forrásanyag megfelel a karakterkorlátoknak, jól kiolvasható belőle a tananyag adott tartalomhoz illeszkedő struktúrája (segíti a gondolattérkép), kulcsinformációk és fö üzenetek azonosíthatók, szakmailag és nyelvhelyesség szempontjából kifogástalan.

Résztvevők

Átfutás idő

Kockázatok e-learning szakértő, szerző, forgatókönyvíró (opc.), gyártásvezető, megbízó, projektvezetö (opc.)

2-4 hét (teljesen új tartalom esetén hosszabb)

A nem kellő körültekintéssel, és/vagy túl kevés szakterület bevonásával készült koncepciók gyakran tartalmaznak olyan „lukakat”, amelyek később a kivitelezés során komoly idő- és költségnövekedést eredményezhetnek. E kockázatot szükséges kivédeni: körültekintő projektvezetés mellett e kockázatok minimalizálhatók.

További kockázat, hogy a megbízó számára nem világosak a koncepcióban meghatározásra kerülő fogalmak, alkalmazni javasolt technológiák. E kockázatot érdemes a következő fázisban minél több látványtervvel, drótváztervvel, minták bemutatásával mérsékelni. Általánosan megfigyelhető, hogy - a partner elearning tapasztalatától függően - még a legvilágosabb keretek között meghatározott projektek esetében is lesznek az eltérö értelmezésből fakadó későbbi nehézségek.

A kockázat további csökkentésére fejlesztői oldalról ellenőrzőlisták alkalmazása, megbízói oldalról sablon dokumentumok jöhetnek szóba.

Nagyon alacsony színvonalú forrásanyag igen komoly probléma lehet, ami nem csak gyenge felépítést, de adott esetben szakami színvonalát tekintve is problémás tartalmat jelent. E kockázatot előzetesen kezelni kifejezetten nehéz, magát a kockázatot el lehet hárítani (akár e-learningben jártas) másik forrásanyagszerző bevonásával, aki kiegészíti vagy átírja a meglévő anyagot.

A rossz forrásanyag mellett megfigyelhetö, hogy túl sok anyagot bocsátanak feldolgozásra, miközben a koncepcióban egy sokkal rövidebb képzés elkészítése 
a feladat. Ez a kockázat egyszerüen mérsékelhető, hiszen számos mérő- és mutatószám a projektvezető rendelkezésére áll, hogy összevesse a forrásanyag mennyiségi paramétereit a végtermékhez kapcsolódó elvárásokkal. Tovább mérsékelhető a kockázat a forgatókönyvírás során. A fő problémát a szakértő szerző „makacssága” jelentheti, amennyiben nem hajlandó csökkenteni vagy átstrukturálni a tartalmat.

Az átadott anyagok még jól felépítettek, átláthatók, szakmailag magas színvonalúak is kifejezetten tankönyviek (pl. nyelvezetük, felépítésük stb.), amelyek ebben az esetben teljeskörü módszertani átdolgozáson kell, hogy átessenek.

Általános kockázatnak tekinthető, de ebben a fázisban jelentős kockázatot jelent, hogy késve kerül átadásra a meglévő vagy akár az új tartalom. Ez a kérdéskör szoros projektvezetés mellett, és előre, jól definiált, határidőkhöz kötött átadásátvételi pontok alkalmazásával támogatható.

Átadás-átvétel aktuális tananyagfejlesztési koncepció, forrásanyag gyüjtemény

Sikerkritériumok A képzési célhoz illeszkedő, a megbízó számára is világosan átadott, mind módszertani, mind technológiai oldalról végiggondolt koncepció mentén indítható a konkrét tananyagok tervezés, kivitelezése.

\section{Kitalálás, tervezés}

\section{Szempont Leírás}

Gyakorlati A koncepcióalkotás során a tervezés megvalósul, az ötletek, újdonságok részletes megvalósulás kifejtésére, átbeszélésére, ötletelésre, innovációra nem marad idő.

Részfolyamatok Ötletelési lépéseket követően kialakíthatók a prioritások és azok a technológiai és módszertani megoldások, amelyek végsősoron segíteni fognak a koncepcióban lefektetett tananyagok elkészítésében az e-learning by design szemlélet mentén.

E szakasz a megértett célok és problémákra adható válaszok összegyüjtése, rendszerezése és végül kiválasztását tartalmazza. Ezek alapján készülhetnek el azok a tervek, akár design koncepciók, amelyek már tartalmazzák mindazokat a formai és módszertani elemeket, amelyekből a tananyag felépül majd. Fontos, hogy meghatározásra kerüljenek a tananyag hosszúságára vonatkozó elvárások is. Bár egyszerủen összefoglalható folyamat szakaszról van szó, mégis a végeredmény szempontjából kulcsfontosságú, kreatív eleméről van szó a fejlesztésnek, amelynek része kell, hogy legyen a megszerzett tudás visszamérés rendszerének kitalálása is.

Résztvevők e-learning szakértő, e-learning designer, grafikus, gyártásvezető, megbízó, projektvezető (opc.)

Átfutás idő 2-3 hét 
Kockázatok

Átadás-átvétel

Sikerkritériumok

4. Alkalmazás, gyártás

\section{Szempont \\ Gyakorlati \\ megvalósítás}

Részfolyamatok
Rosszul kerülnek meghatározásra a prioritások, és ezért sok olyan terv és ötlet készül el, amely sok időt emészt fel, de mégsem jelentenek megoldást, illetve továbblépésre lehetőséget.

végleges tananyagfejlesztési koncepció

Egy olyan tananyagfejlesztési koncepció készül el, amely minden elemében megfelel az e-learning by design szemléletnek, és megoldást nyújt az azonosított problémára, miközben figyelembe veszi és meghatározza a fejlesztés az emberi (mert végül tanulni kellene az anyagokból) tényezőket is.

\section{Résztvevők forgatókönyvíró, grafikus, e-learning szakértő, megbízó, gyártásvezető, tananyag szerkesztő, projektvezető (opc.) \\ Átfutás idő 2-4 hét \\ Kockázatok Az arculati tervezés kapcsán komoly kockázatot jelenthet két tényező: 1. az arculat igen szubjektíven megítélhető kérdéskör, minden résztvevőnek lesz róla véleménye, mert ízlése (valamilyen) mindenkinek van. A kockázat azonban csökkenthető: mivel a többség számára a látványterv az első „kézzelfogható találkozás" a tananyaggal, így fontos, hogy letisztult, az aktuális (webes)}


trendeknek megfelelö legyen. 2. Jellemzö kockázat még, hogy nem minden esetben lehet a vállalati arculathoz jól illeszteni a kívánt tartalmi elemeket, vagy az adott megbízó/vezető (szubjektív véleménye miatt) nem szeretné, ha illeszkedne. Ezek később, más osztályok bevonása során jönnek felszínre. A kockázat kezelésére egyértelmü átadás-átvételi pontokat szükséges itt is rögzíteni, és felelős döntéshozót szükséges bevonni. További kockázat, hogy rengeteg idő míg elkészül a mindenki számára elfogadható arculat, hiszen - mint fent esztétikai véleménye mindenkinek van. E kockázat szoros projektmenedzsmenttel, és részletes ütemezéssel kezelhető.

A prototípus kapcsán ismert kockázat, hogy olyan technológiai elemet tartalmaz, amely a pontos, részletekre is kitérő igényfelmérés ellenére nem lejátszható az adott környezetben. Kockázatkezelési oldalról ezért a prototípus véglegesítésére minden esetben szükséges fejlesztési időt allokálni. Tovább általános kockázat, hogy a prototípus során találkozik sok esetben érdemben először a megbízó interaktív és/vagy multimédiás tartalmakkal, és az elmondott (akár bemutatott) elemekhez képest más elképzelései vannak. E kockázat ugyancsak komoly, itt is a véglegesítésre allokált (a tervezéskor még fölöslegesen tűnő) fejlesztésiidő allokáció, és a koncepcióban rögzített elemek részletes (lehetöleg kattintható bemutatóval támogatott) specifikációja lehet a megoldás.

A forgatókönyvek kapcsán a leggyakoribb kockázat azok időbeli elcsúszása. hiszen a forgatókönyvírás igen kreatív feladat. A kockázatot elsősorban olyan ütemezés kialakításával lehet mérsékelni, amely nem akarja elkapkodni e előkészítő feladatot. További kockázat, hogy a forgatókönyv összeállitása során derül fény a szakanyag (addig feltáratlan) hibáira vagy terjedelmi problémáira (pl. túl hosszú, túl rövid egy adott tartalomhoz képest). E kockázatot e-learning szakmai oldalról más módszertani és/vagy technológiai megoldások (és kapcsolódó szakértők) bevonásával lehet mérsékelni az iteratív ciklusok folyamatos fenntartásával, ütemezésével.

$\mathrm{Az}$ átadásra kerülő anyag kapcsán megfigyelt kockázat, hogy technológia probléma merül fel hiába a gondos tervezés. Itt a rugalmas gyártástechnológia kiválasztásával lehet megoldást találni.

Átadás-átvétel arculati és látványterv, prototípus, forgatókönyv, tananyag

Sikerkritériumok Olyan komplett előkészítési dokumentáció áll össze, amely alapján egyfelől a gyártási feladatok további komplikációk nélkül elvégezhetők. Másfelől pedig a megbízó pontos képet kap arról, hogy milyen lesz az átadásra kerülő végleges tananyag formai, technikai és tartalmi oldalról egyaránt.

\section{Mérés, előkészítés}

\section{Szempont Leírás}




\begin{tabular}{|c|c|}
\hline $\begin{array}{l}\text { Gyakorlati } \\
\text { megvalósulás }\end{array}$ & $\begin{array}{l}\text { Megfigyelések alapján elmondható, hogy ez a folyamat inkább tesztelési és } \\
\text { észrevételezési tartalommal kerül feltöltésre, és nincs folytatása az egyes } \\
\text { projekteknek, így nem is elökészület, hanem kifejezetten lezáró szakasz. }\end{array}$ \\
\hline Részfolyamatok & $\begin{array}{l}\text { Az elkészített megoldások átadását követően észrevételezi és teszteli a megoldást } \\
\text { a megbízó. Fontos, hogy ne csak klasszikus technológiai tesztelés valósuljon } \\
\text { meg, hanem legyenek mérhető adatok a tananyag minőségével, a tanulás } \\
\text { eredményességével kapcsolatosan is. Kérdőíves vagy akár fókuszcsoportos } \\
\text { módszerek alkalmazásával. } \\
\text { Ezek az ismeretek építhetők bele a folytatás során kialakításra kerülő frissített } \\
\text { tananyagokba, itt kerülnek definiálásra az új problémák, vagy a tananyag által } \\
\text { lesznek pontosabban értelmezhetők a korábban feltártak. }\end{array}$ \\
\hline Résztvevők & 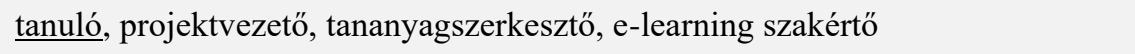 \\
\hline Átfutás idő & 1-2 hét, majd az után követes 3-6-12 hónap \\
\hline Kockázatok & $\begin{array}{l}\text { Kevés erőforrás áll rendelkezésre az éles indítást megelőzően, ezért nem derülnek } \\
\text { ki a problémák. Más technológiai környezetben valósul meg végül a projekt, mint } \\
\text { ahol a tervezés és a vizsgálódások zajlottak, így számos technikai probléma } \\
\text { adódik, ami komolyan ront a felhasználói élményen. }\end{array}$ \\
\hline Átadás-átvétel & mérési jegyzőkönyvek \\
\hline Sikerkritériumok & $\begin{array}{l}\text { Akkor tekinthetjük sikeresnek az előkészítés fázisát, hogy ha elégséges és jó } \\
\text { minőségü bemeneti információt tartalmaz a tananyag további fejlesztéséhez. Ez } \\
\text { igaz lehet mind technológiai, mind módszertani kérdések esetében. Ehhez } \\
\text { szükséges megfelelő időtávon az után követes. }\end{array}$ \\
\hline
\end{tabular}

\subsection{Tananyagfejlesztő eszközökről részletesen}

\subsubsection{Alapképesség vizsgálata}

Az alapképességek ellenőrzése során az alábbi szempontokat szükséges megvizsgálni, és bármelyik esetében a nemleges válasz az adott eszköz esetében azt jelenti, hogy nem tudjuk alkalmazni a fejlesztések során. Ennek megfelelően a vizsgálódás sorrendjének kötöttségére is érdemes figyelni. PECA elvek mentén ezek tekinthetők a kemény elvárásoknak. (Comella-Dorda et al., 2002) Az alapképességek vizsgálatához első lépésként szükséges felállítani az adott tananyagfejlesztés informatikai, felhasználási és funkcionális irányvonalait.

Informatikai irányelvek meghatározása során az alábbiakat szükséges meghatározni: fejlesztéshez alkalmazott operációs rendszer(ek), futtatás során alkalmazni kívánt böngésző(k) és verzió(k), reszponzivitási elvárások, hang-lejátszási képesség (igen/nem), 
általánosan a sávszélességről (alacsony/megfelelö/magas), elvárás a naprakészséggel kapcsolatosan.

Felhasználási irányelvek elsősorban jogi szempontból relevánsak, e kérdések technológiai és módszertani szempontból nem tünnek fontos tényezőnek, azonban sok esetben mégis erös, akár döntési pontként értelmezhető hatással vannak a tananyagfejlesztésre. Tipikusan a jogi megfelelőséget firtató kérdések azok, amelyek ritkán kerülnek be egy tananyagfejlesztési (vagy bármilyen egyéb) fejlesztési folyamatba. Jelen esetben is e tényező kiemelése nem véletlen, hanem kifejezetten valós fejlesztési tapasztalatként került kifejtésre.

Funkcionális irányelvek meghatározása során egyfelöl figyelembe kell venni az adott szoftvertől elvárt eredményt, másfelől pedig három kategóriába sorolandók a szoftvertől elvárt képességek: kötelező, hasznos, ,,jó, ha van”. Az alapképességek vizsgálata során a „kötelező” kategória elemei vizsgálandók.

Az irányelvek meghatározását követően eldöntendő kérdésként az alábbi szempontok vizsgálandók.

\begin{tabular}{|c|c|c|c|}
\hline Ssz. & Terület & Kérdés & Meghatározás \\
\hline 1. & $\begin{array}{l}\text { Kompatibilis } \\
\text { vizsgálata }\end{array}$ & $\begin{array}{l}\text { Az informatikai } \\
\text { irányelveknek megfelelö } \\
\text { tananyag fejleszthető-e az } \\
\text { eszközzel? }\end{array}$ & $\begin{array}{l}\text { Legtöbbször gyorsan megállapítható, hogy egy } \\
\text { adott szoftver futtatható-e egy bizonyos } \\
\text { környezetben, amely elsősorban az operációs } \\
\text { rendszert, másodsorban pedig a kiegészítő } \\
\text { szoftvereket jelenthet: pl. Adobe Flash, Java stb. } \\
\text { Legtöbb esetben a kifejezetten Machintosokra } \\
\text { készített alkalmazások esnek ki ilyen esetben, } \\
\text { hiszen a legtöbb fejlesztési környezet alapját } \\
\text { Windows-os környezet jellemzi. }\end{array}$ \\
\hline 2. & $\begin{array}{l}\text { Funkciók } \\
\text { vizsgálata }\end{array}$ & $\begin{array}{l}\text { Tartalmazza-e a kötelező } \\
\text { funkcionális elvárásokban } \\
\text { megfogalmazottokat az } \\
\text { adott szoftver? }\end{array}$ & $\begin{array}{l}\text { A fejlesztési folyamatban betöltött vagy elvárt } \\
\text { szereptől függően meghatározható egy olyan } \\
\text { funkcionális minimumkövetelmény lista, amely } \\
\text { alapvető döntési pontként jelenhet meg egy adott } \\
\text { szoftver alkalmassága esetén. }\end{array}$ \\
\hline 3. & $\begin{array}{l}\text { Naprakészség } \\
\text { vizsgálata }\end{array}$ & $\begin{array}{l}\text { Új vagy az informatikai } \\
\text { irányelvekben } \\
\text { meghatározottak szerint } \\
\text { naprakésznek tekinthető-e } \\
\text { az eszköz? }\end{array}$ & $\begin{array}{l}\text { Mivel alapvetően informatikai eszközökröl van } \\
\text { szó ezért technológiai szempontból a naprakész } \\
\text { eszközök használata elengedhetetlen szempont. }\end{array}$ \\
\hline
\end{tabular}




\begin{tabular}{|c|c|c|c|}
\hline 4. & $\begin{array}{l}\text { Szabvány } \\
\text { vizsgálat }\end{array}$ & $\begin{array}{l}\text { Szabványos tananyagok } \\
\text { (vagy tananyagelemek) } \\
\text { elóállítására alkalmas-e az } \\
\text { eszköz? }\end{array}$ & $\begin{array}{l}\text { Az e-learning tananyagok az korábbiakban már } \\
\text { bemutatott SCORM szabványnak szükséges } \\
\text { megfelelniük. Azonban itt nem csak ezt, hanem } \\
\text { adott tananyagelemek (pl. animáció) esetében } \\
\text { azok szabványossága is vizsgálandó. }\end{array}$ \\
\hline 5. & $\begin{array}{l}\text { Kereskedelmi } \\
\text { felhasználás } \\
\text { vizsgálata }\end{array}$ & $\begin{array}{l}\text { Az eszköz által készített } \\
\text { tananyag vagy } \\
\text { tananyagelem megfelel-e } \\
\text { a felhasználási } \\
\text { irányelveknek } \\
\text { megfelelöen? }\end{array}$ & $\begin{array}{l}\text { Ritkán, de elképzelhető, hogy egy eszköz } \\
\text { fejlesztője nem engedélyezi az eszközzel } \\
\text { készített tartalmak kereskedelmi felhasználását, } \\
\text { hanem pl. csak felsőoktatási terjesztést } \\
\text { engedélyez. Illetve a kereskedelmi felhasználás } \\
\text { formája is korlátozva lehet pl. területileg vagy } \\
\text { időben. Ezeket a szempontokat is érdemes } \\
\text { előzetesen felmérni, és ha nem egyezik a } \\
\text { felhasználási irányelvekkel, úgy az adott eszköz } \\
\text { használatát elvetni. }\end{array}$ \\
\hline
\end{tabular}

Elképzelhető, hogy a válaszok is hatással lehetnek az irányelvekre, így a fenti folyamatot minden esetben egy iteratív, önmagát akár több körben újra vizsgáló folyamatként érdemes tekinteni. Amennyiben a fenti négy kérdésre az adott eszköz esetében igen válaszok születnek, úgy érdemes tovább vizsgálni.

\subsubsection{Jellemzők összegyüjtése}

Amikor megbizonyosodtunk, hogy egy eszköz alkalmas lehet, utána következik egy leíró szakasz, amely során mélyebben vizsgálhatjuk az adott szoftver tulajdonságait. Az eredmények bemeneti információként szolgálnak majd a következő fázisok számára. E vizsgálódás során az 25. táblázatban összefoglalt területek érdemes részletesen megvizsgálni, és leíró jelleggel összegyüjteni az információkat.

\begin{tabular}{|l|l|l|}
\hline Ssz. & Terület & Meghatározás \\
\hline 1. & $\begin{array}{l}\text { Alkalmazhatóság } \\
\text { lehatárolása és } \\
\text { eredménytermék }\end{array}$ & $\begin{array}{l}\text { Fontos pontosan lehatárolni, hogy az adott szoftver milyen feladatra } \\
\text { vagy feladatokra alkalmas, illetve, hogy milyen célok elérésére kívánjuk } \\
\text { alkalmazni. Jellemző, hogy egy adott termék multifunkciós eszközként } \\
\text { rosszabb értékelést kap, mint egyes részei, amelyek sokkal } \\
\text { alkalmasabbak bizonyos feladatok ellátására, mint a versenytársak } \\
\text { eszközei. Ennek megfelelően elképzelhető, hogy egy adott szoftver több } \\
\text { értékelési területen is megjelenik, mint különálló megoldás. }\end{array}$ \\
\hline
\end{tabular}




\begin{tabular}{|c|c|c|}
\hline 2. & Árazás & $\begin{array}{l}\text { A felelös döntés egyértelmü része egy adott szoftver esetében is a } \\
\text { kapcsolódó költségek feltérképezése. Ismert árazási megoldások között } \\
\text { az egyszeri licenc díjak és a per felhasználó szerinti kalkulált havi/éves } \\
\text { licencdíjak. }\end{array}$ \\
\hline 3. & Funkcionalitás & $\begin{array}{l}\text { Az eszköz adott fejlesztési folyamatban betöltött szerepe szerint } \\
\text { szükséges meghatározni azokat a funkcionális szempontokat, amelyek } \\
\text { az alábbi kategóriákba esnek: kötelezö, hasznos, „jó, ha van”. A } \\
\text { szükséges funkciók meghatározásához az amerikai Association for } \\
\text { Talent Development non-profit szervezet gondozásában megjelent e- } \\
\text { learning alapvetéseket tartalmazó könyvhöz készült eszköz } \\
\text { ellenőrzőlistát vettem alapul (Elkins és Pinder, 2015). }\end{array}$ \\
\hline 5. & $\begin{array}{l}\text { Kereskedelmi } \\
\text { felhasználás pontos } \\
\text { részletei }\end{array}$ & $\begin{array}{l}\text { Amennyiben a felhasználási irányelveknek meg is felel egy adott } \\
\text { szoftver, érdemes részletesen megismerni a felhasználás formai és } \\
\text { tartalmi elemeit. }\end{array}$ \\
\hline 6. & $\begin{array}{l}\text { Terméktámogatás és } \\
\text { gyártó } \\
\text { megbízhatósága }\end{array}$ & $\begin{array}{l}\text { A végső döntés meghozása szempontjából fontos elem lehet a termék } \\
\text { gyártójának megbízhatósága, a piacon betöltött szerepe, illetve a } \\
\text { terméktámogatás formája és mikéntje. }\end{array}$ \\
\hline
\end{tabular}

Ahogy az alapképességek vizsgálata is egy iteratív folyamat, úgy a fenti területeken folytatott további információgyüjtés és döntéselőkészítési lépések esetében is fontos, hogy a leírt megállapítások tükrében újra és újra visszatérjünk egy-egy korábbi területhez (Comella-Dorda et al., 2002). Az információk begyüjtésének számos módja ismert és végrehajtható dokumentáció áttekintésétől kezdve, internetes fórumok olvasásán és szakértői elemzések áttekintésén keresztül, bemutató megoldások megtekintésével, a gyártóval történő kapcsolatfelvételig, vagy akár az adott szoftvert alkalmazó kolléga, ismerős megkérdezéséig (Kunda és Brooks, 2003). Az e-learning tananyagfejlesztési folyamathoz illeszkedően az alábbi információforrásokra támaszkodik ez a fázis: 1. gyártó honlapja, 2. szakértői fórumok és blogok, 3. videós bemutatók megtekintése. Az egyes funkciók gyüjtéséhez és elemzéséhez kialakított ellenőrzőlista nyújtott segítséget, amely ugyancsak a mellékletben érhető el (Elkins és Pinder, 2015).

\subsubsection{Tesztelés és kipróbálás}

A következő lépés az eszközök értékelésében azok kipróbálása, amelyek a fenti két lépés alapján megfelelők lehetnek. Általában a kipróbálást 7 napos vagy 30 napos ún. próbaverziók ingyenes telepítése biztosítja a fizetős alkalmazások esetében. Az előző 
pontban gyüjtött információkat értékelve és kiegészítve a tesztelés és kipróbálás eredményeit pontozzuk, és súlyozás segítségével alakítjuk ki egy szoftver végleges értékelését. E pontszám még nem reprezentálja a döntést egy adott eszköz alkalmazhatóságával kapcsolatosan, de megkerülhetetlen alapja. A széleskörü és igen különböző felhasználási szcenáriók okán, egy magasra értékelt eszköz pont úgy lehet a legjobb választás, mint végül egy elvetett eszköz.

A pontozási módszertan alapja a szakirodalomban részletesen feldogozott páronkénti összehasonlító és Delphi technika (Comella-Dorda et al., 2002), amelyek egyfelől lehetőséget biztosítanak az egyes szempontok egymáshoz viszonyításában, másfelől pedig az e-learning tananyagfejlesztés esetében már sokszor kiemelt, különbözö nézőpontú résztvevők több körös, visszacsatolásokban gazdag, egyeztetési metódusához jól illeszkedik. E vizsgálódások esetében a személyes egyeztetés sokat gyorsít az amúgy a módszertanban rejlő elnyúló értékelési folyamat kockázata tekintetében.

A pontozást 1-5-ig terjedő skálán (ahol az 1-es a legrosszabb, és az 5-ös a legjobb érték), a fentiek tükrében az alábbi táblázatban bemutatott súlyozások mellett javasolt végrehajtani. A kifejtett szisztéma kialakítása több éves finomhangolás eredménye. Természetesen egyes speciális körülmények esetében megfontolandó, hogy eltérjünk ezektől a súlyozási szorzóktól, pl. amennyiben egy-egy fejlesztés kiemelten költségérzékeny, úgy értelemszerűen az ár-érték arány súlyértékét érdemes megemelni, de csak kis mértékben.

\begin{tabular}{|l|l|c|}
\hline Ssz. & Szempont & Súlyozás \\
\hline $\mathbf{1 .}$ & Stabilitás és megbízhatóság & 0,29 \\
\hline $\mathbf{2 .}$ & Használhatóság és kinézet & 0,23 \\
\hline $\mathbf{3 .}$ & Ár-érték arány & 0,19 \\
\hline $\mathbf{4 .}$ & Testre szabhatóság & 0,15 \\
\hline 26. táblázat - Pontozási szorzók szoftverek értékelése során (saját táblázat 2018)
\end{tabular}

A pontozási értékeknél az egyes szempont esetében kidolgozott iránymutatás a melléklet folytatásában megtalálható. A pontozás eredményeit pedig, az 1-5-ig terjedő pontokat, egy sugár diagramm segítségével érdemes ábrázolni, hiszen fontos ugyan a „végső” (ugyancsak 1-5 közötti) pontérték is, de a döntést nem szabad, hogy ez az egy érték befolyásolja. 


\subsubsection{Döntés}

Az előző pontokban összegyüjtött és kiértékelt eredmények alapján lehetőségünk van kiválasztani az adott feladatokkal kapcsolatosan legjobbnak bizonyult szoftvert. Azonban a gyakorlat során nem ilyen jellegü összehasonlításra, hanem sokkal inkább a folyamatosan fejlesztett, illetve az újabb és újabb szoftverek megjelenésére alkalmazható a fenti metódus, úgy hogy gyors döntést lehessen hozni egy eszköz alkalmazásával vagy egy másik lecserélésével összefüggésben.

Maga a döntési folyamat azonban nem csak egy igen-nem változó mentén kell, hogy eredményt mutasson, hanem egy összefoglaló adatlap készül el az adott szoftver, adott verziójáról, hiszen a folyamatosan változó és fejlődő, átalakuló projektigények mentén még a legjobbnak ítélt szoftverek sem biztos, hogy alkalmazhatók egy adott fejlesztési folyamatban. Illetve ugyanígy elképzelhető, hogy egy alacsonyabbra értékelt eszköz mégis alkalmazható egy másik szituációban. Éppen ezért kiemelten fontos gyűjteni, és szisztematikusan vizsgálni, majd dokumentálni az eszközöket.

\subsubsection{Tananyagfejlesztő szoftverek értékeléséhez iránymutatás}

\begin{tabular}{|c|c|c|c|}
\hline Ssz. & Szempont & Pontszám & Értékelési segéd \\
\hline \multirow[t]{5}{*}{1.} & \multirow[t]{5}{*}{$\begin{array}{l}\text { Stabilitás és } \\
\text { megbízhatóság }\end{array}$} & 1 & $\begin{array}{l}\text { Az adott szoftver összeomlik egy nagy méretü tartalom (pl. } \\
\text { 2GB-nál nagyobb videó) betöltését követően. Vagy az egy } \\
\text { munkanapra eső összeomlások száma meghaladja az ötöt. }\end{array}$ \\
\hline & & 2 & $\begin{array}{l}\text { Az adott szoftver összeomlik egy nagy méretü tartalom (pl. } \\
\text { 1GB-nál nagyobb videó) betöltését követően. Vagy az egy } \\
\text { munkanapra eső összeomlások száma meghaladja a hármat. }\end{array}$ \\
\hline & & 3 & $\begin{array}{l}\text { Az adott szoftver nem omlik össze, de igen komoly lelassulás } \\
\text { tapasztalható a komplex feladatok elvégzése során. }\end{array}$ \\
\hline & & 4 & $\begin{array}{l}\text { Az adott szoftver nem omlik össze, de észrevehető lelassulás } \\
\text { tapasztalható a komplex feladatok elvégzése során. }\end{array}$ \\
\hline & & 5 & $\begin{array}{l}\text { Az adott szoftver nem omlik össze, és komplex feladatok } \\
\text { elvégzése során sem tapasztalható lassulás. }\end{array}$ \\
\hline \multirow[t]{2}{*}{2.} & \multirow[t]{2}{*}{$\begin{array}{l}\text { Használhatóság és } \\
\text { kinézet }\end{array}$} & 1 & $\begin{array}{l}\text { A kezelőfelület elavult és/vagy komoly nehézséget jelent } \\
\text { megtalálni a legegyszerűbb funkciókat is. }\end{array}$ \\
\hline & & 2 & $\begin{array}{l}\text { A kezelőfelület elavult és/vagy nehézséget jelent megtalálni } \\
\text { vagy elvégezni a legegyszerübb funkciókat is. }\end{array}$ \\
\hline
\end{tabular}




\begin{tabular}{|c|c|c|c|}
\hline & & 3 & $\begin{array}{l}\text { A kezelőfelület nem elavult, de nem is felel meg a legújabb } \\
\text { elvárásoknak. A funkciók egy része nehezen érhető el vagy } \\
\text { végezhető el. }\end{array}$ \\
\hline & & 4 & $\begin{array}{l}\text { A kezelőfelület modern, és nem jelent kihívást megtalálni és } \\
\text { elvégezni az egyszerübb funkciókat sem. }\end{array}$ \\
\hline & & 5 & $\begin{array}{l}\text { A kezelöfelület kifejezetten modern, jól vezeti a felhasználót, } \\
\text { és könnyű elvégezni a bonyolultabb funkciókat is. }\end{array}$ \\
\hline \multirow[t]{5}{*}{3.} & \multirow[t]{5}{*}{ Ár-érték arány } & 1 & $\begin{array}{l}\text { A szoftver által nyújtott funkcionalitások száma messze } \\
\text { nincs összhangban a szoftver (a versenytársak } \\
\text { viszonylatában) árával. }\end{array}$ \\
\hline & & 2 & $\begin{array}{l}\text { A szoftver által nyújtott funkcionalitások száma nincs } \\
\text { összhangban a szoftver (a versenytársak viszonylatában) } \\
\text { árával. }\end{array}$ \\
\hline & & 3 & $\begin{array}{l}\text { A szoftver által nyújtott funkcionalitások száma nagyjából } \\
\text { összhangban a szoftver (a versenytársak viszonylatában) } \\
\text { árával. }\end{array}$ \\
\hline & & 4 & $\begin{array}{l}\text { A szoftver által nyújtott funkcionalitások száma összhangban } \\
\text { van a szoftver (a versenytársak viszonylatában) árával. }\end{array}$ \\
\hline & & 5 & $\begin{array}{l}\text { A szoftver által nyújtott funkcionalitások száma kiemelkedik } \\
\text { a szoftver (a versenytársak viszonylatában) árával szemben. }\end{array}$ \\
\hline \multirow[t]{5}{*}{4.} & \multirow[t]{5}{*}{ Testre szabhatóság } & 1 & $\begin{array}{l}\text { A szoftver egyáltalán nem nyújt lehetőséget a funkciók testre } \\
\text { szabására. }\end{array}$ \\
\hline & & 2 & $\begin{array}{l}\text { A szoftver lehetőséget nyújt a funkciók testre szabására, de } \\
\text { nem a lényeges funkciók tekintetében. }\end{array}$ \\
\hline & & 3 & $\begin{array}{l}\text { A szoftver lehetőséget nyújt a funkciók testre szabására } \\
\text { kielégítő mértékben. }\end{array}$ \\
\hline & & 4 & $\begin{array}{l}\text { A szoftver lehetőséget nyújt a lényeges funkciók testre } \\
\text { szabására is. }\end{array}$ \\
\hline & & 5 & $\begin{array}{l}\text { A szoftver kiemelkedő lehetőségeteket nyújt a funkciók } \\
\text { testre szabására. }\end{array}$ \\
\hline \multirow[t]{2}{*}{5.} & \multirow[t]{2}{*}{$\begin{array}{l}\text { Dokumentáció és } \\
\text { támogatás }\end{array}$} & 1 & $\begin{array}{l}\text { Szinte semmilyen dokumentáció vagy terméktámogatás nem } \\
\text { található. Sem fejlesztői közösség, sem a fejlesztő sem } \\
\text { található. }\end{array}$ \\
\hline & & 2 & $\begin{array}{l}\text { Nagyon alapszintủ dokumentáció és/vagy terméktámogatás } \\
\text { található, amely leginkább az alapfunkciókra korlátozódik. } \\
\text { Fejlesztői közösség nincs. }\end{array}$ \\
\hline
\end{tabular}




\begin{tabular}{|c|c|l|}
\hline & 3 & $\begin{array}{l}\text { Alapszintü dokumentáció és/vagy terméktámogatás található, } \\
\text { amely nem csak az alapfunkciókra korlátozódik, minimális } \\
\text { fejlesztői közösséggel. }\end{array}$ \\
\hline 4 & $\begin{array}{l}\text { Magas szintül dokumentáció és/vagy terméktámogatás } \\
\text { található, amely széles körben lefedi a funkciókat, } \\
\text { általánosan kisebb, de nem elhanyagolható fejlesztői } \\
\text { közösséggel. }\end{array}$ \\
\hline 5 & $\begin{array}{l}\text { Magas szintű dokumentáció és gyors reagálású } \\
\text { terméktámogatás található, amely széles körben lefedi a } \\
\text { funkciókat, sok esetben erös fejlesztői közösséggel. }\end{array}$ \\
\hline 27. táblázat - Értékelési segédlet (saját táblázat 2018)
\end{tabular}

\subsubsection{Tananyagfejlesztő szoftverek adatlapjai}

\subsubsection{Articulate Storyline}

\begin{tabular}{|l|l|l|l|}
\hline Szoftver gyártója: & Szoftver neve: & Verzió: & Alkalmazási kategória: \\
\hline Articulate & Storyline & 3 & Komplex tananyagfejlesztő szoftver \\
\hline
\end{tabular}

\begin{tabular}{|c|c|}
\hline Jellemzők & Jellemzők leírása \\
\hline $\begin{array}{l}\text { Alkalmazhatóság lehatárolása } \\
\text { és eredménytermék }\end{array}$ & $\begin{array}{l}\text { Szabványos e-learning tananyagok előállítására alkalmas, Amerikai } \\
\text { Egyesült Államokban fejlesztett, funkciókban gazdag } \\
\text { tananyagfejlesztő szoftver. }\end{array}$ \\
\hline Árazás & Éves licenc díjas, 1,299 USD ${ }^{37}$ / év / két felhasználó \\
\hline Funkcionalitás & $\begin{array}{l}\text { Articulate szoftvercsalád része, arculati és tartalom elrendezési } \\
\text { sablonok kezelése, beépített karakterek, szövegszerkesztés, idővonal, } \\
\text { eseménykiváltók és rétegek kezelése, diaminta, nagyítás, tartalom } \\
\text { importálás (pl. Microsoft PowerPoint), animáció és interakciók } \\
\text { készítése, változók és pontszámok kezelése, integrált kiegészítők } \\
\text { (gombok, jelölők, hotspot--ok, lightbox-ok, beviteli mezők, } \\
\text { egérmegjelenítés, görgethető panelek), képernyőkép felvétel, } \\
\text { szoftverszimuláció, multimédiás tartalom importálása, feliratok } \\
\text { kezelése, web- és Flash tartalmak kezelése, feladatok kezelése } \\
\text { (ürlapok, kérdések importálása, negatív pontozás, kérdésbankok, } \\
\text { eredményképernyő, kvízek), reszponzív megjelenítés, html5 kezelés, } \\
\text { akadálymentes tartalomgyártás, szabványos exportálás: } \\
\text { - videó, }\end{array}$ \\
\hline
\end{tabular}

${ }^{37}$ Forrás: https://articulate.com/pricing, éves előfizetési díj cégek számára. 


\begin{tabular}{|c|c|}
\hline & 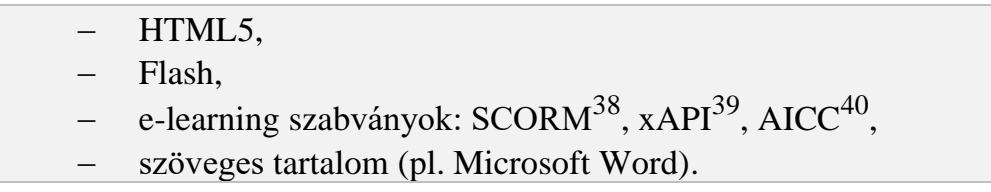 \\
\hline $\begin{array}{l}\text { Kereskedelmi felhasználás } \\
\text { pontos részletei }\end{array}$ & $\begin{array}{l}\text { A szoftverrel készített tananyagok felhasználási joga átadható a } \\
\text { végfelhasználóknak, és ők is tovább értékesíthetik. Részletek: } \\
\text { https://articulate.com/terms }\end{array}$ \\
\hline $\begin{array}{l}\text { Terméktámogatás és gyártó } \\
\text { megbízhatósága }\end{array}$ & $\begin{array}{l}\text { Az Articulate } 2002 \text { óta nyújt tananyagfejlesztő szoftvert, globális } \\
\text { jelenléttel, és igen széles terméktámogatással mind a dokumentáció, } \\
\text { mind a közösségek tekintetében. Megbízható gyártónak tekinthető. }\end{array}$ \\
\hline
\end{tabular}

\begin{tabular}{|l|c|c|c|}
\hline $\begin{array}{l}\text { Pontozási } \\
\text { kategóriák }\end{array}$ & $\begin{array}{c}\text { Kategória } \\
\text { jel }\end{array}$ & Pontszámok \\
\hline $\begin{array}{l}\text { Stabilitás és } \\
\text { megbízhatóság }\end{array}$ & $\mathrm{A}$ & 4 & Sugár diagram \\
\hline $\begin{array}{l}\text { Használhatóság és } \\
\text { kinézet }\end{array}$ & $\mathrm{B}$ & 4,5 \\
\hline Ár-érték arány & $\mathrm{C}$ & 4 & \\
\hline Testre szabhatóság & $\mathrm{D}$ & 3,97 \\
\hline $\begin{array}{l}\text { Dokumentáció és } \\
\text { támogatás }\end{array}$ & $\mathrm{E}$ & \\
\hline Súlyozott pontszám & & $\mathrm{C} ; 4$ \\
\hline
\end{tabular}

\subsubsection{Adobe Captivate}

\begin{tabular}{|l|l|l|l|}
\hline Szoftver gyártója: & Szoftver neve: & Verzió: & Alkalmazási kategória: \\
\hline Adobe & Articulate & 2017 & Komplex tananyagfejlesztő szoftver \\
\hline
\end{tabular}

\begin{tabular}{|l|l|}
\hline Jellemzők & Jellemzők leírása \\
\hline $\begin{array}{l}\text { Alkalmazhatóság lehatárolása } \\
\text { és eredménytermék }\end{array}$ & $\begin{array}{l}\text { Szabványos e-learning tananyagok előállítására alkalmas, Amerikai } \\
\text { Egyesült Államokban fejlesztett, funkciókban gazdag } \\
\text { tananyagfejlesztő szoftver. }\end{array}$ \\
\hline
\end{tabular}

\footnotetext{
${ }^{38} \mathrm{https} / / / \mathrm{scorm} . c o m / \mathrm{scorm}-\mathrm{explained} /$

${ }^{39}$ https://xapi.com/overview/

${ }^{40}$ https://en.wikipedia.org/wiki/Aviation_Industry_Computer-Based Training_Committee
} 


\begin{tabular}{|c|c|}
\hline Árazás & Havi vagy örök licenc: 30 EUR $^{41}$ / hó vagy 1099 EUR / év \\
\hline Funkcionalitás & $\begin{array}{l}\text { Az Adobe szoftvercsalád része, kifejezetten széleskörü } \\
\text { funkcionalitással: beépített arculati megoldások (pl. dobozok), nem } \\
\text { mobil képernyöre tervezett tartalom automatikus átalakítása, } \\
\text { képernyőkép rögzítő funkció (iOS is), szoftverszimuláció készítés, } \\
\text { PowerPoint importálás, akadálymentes tartalomgyártás, összetett } \\
\text { események kezelése, széles LMS és egyéb (pl. HTML5, SCORM) } \\
\text { exportálási lehetőségek, több állapotú objektumok kezelése, integrált } \\
\text { Adobe termékek (pl. Creative Cloud, Captivate Prime, Captivate Draft, } \\
\text { Typekit), összetett kvízek, reszponzív tartalom kezelés, audio-video } \\
\text { szinkronizáció, hozd és vidd típusú interakciók, diaminta nézet. }\end{array}$ \\
\hline $\begin{array}{l}\text { Kereskedelmi felhasználás } \\
\text { pontos részletei }\end{array}$ & $\begin{array}{l}\text { A szoftverrel készített tananyagok felhasználási joga teljes egészében } \\
\text { a tartalom készítöjét illeti meg: „Az Ön által létrehozott Tartalmak } \\
\text { tulajdonjoga Önt illeti meg. Az Ön által létrehozott Tartalmakkal } \\
\text { szemben semmilyen tulajdonjogi követelésünk nincs." }{ }^{42} \text { Részletek: } \\
\text { https://www.adobe.com/hu/legal/terms.html }\end{array}$ \\
\hline $\begin{array}{l}\text { Terméktámogatás és gyártó } \\
\text { megbízhatósága }\end{array}$ & $\begin{array}{l}\text { A Captivate szoftver még más elnevezéssel (Flashcam, Robodemo), és } \\
\text { lényegesen kevesebb funkcióval } 2002 \text { óta érhető el. Az Adobe 2006- } \\
\text { ban vásárolta fel a Macromedia szoftverfejlesztő céget, és e felvásárlás } \\
\text { keretében került hozzá az akkor már Captivate néven futó szoftver is. } \\
\text { Tavaly a szoftver 10. verzióját adták ki } 2017 \text { néven. Az Adobe } \\
\text { kifejezetten megbízható gyártónak tekinthető. }\end{array}$ \\
\hline
\end{tabular}

\begin{tabular}{|l|c|c|c|}
\hline $\begin{array}{l}\text { Pontozási } \\
\text { kategóriák }\end{array}$ & $\begin{array}{c}\text { Kategória } \\
\text { jel }\end{array}$ & Pontszámok & Sugár diagram \\
\hline $\begin{array}{l}\text { Stabilitás és } \\
\text { megbízhatóság }\end{array}$ & A & 4 & \\
\hline $\begin{array}{l}\text { Használhatóság és } \\
\text { kinézet }\end{array}$ & B & 3,5 & \\
\hline Ár-érték arány & C & 4 & \\
\hline Testre szabhatóság & D & 2,5 & \\
\hline $\begin{array}{l}\text { Dokumentáció és } \\
\text { támogatás }\end{array}$ & E & 5 & \\
\hline
\end{tabular}

${ }^{41}$ Forrás: https://www.adobe.com/hu/products/captivate/buying-guide.html

${ }^{42}$ Forrás: Adobe Általános Szerződési Feltételek, 4. Az Ön által létrehozott tartalmak. 4.2 Tulajdonjog pont: https://www.adobe.com/hu/legal/terms.html 


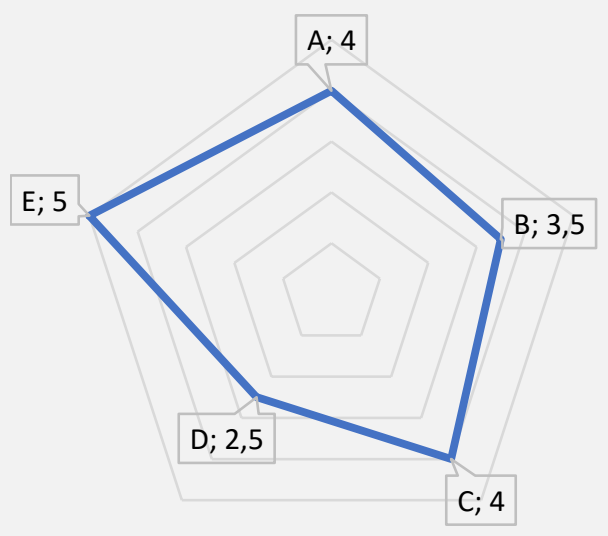

\subsubsection{Trivantis Lectora Inspire}

\begin{tabular}{|l|l|l|l|}
\hline Szoftver gyártója: & Szoftver neve: & Verzió: & Alkalmazási kategória: \\
\hline Trivantis & Lectora Inspire & 17 & Komplex tananyagfejlesztő szoftver \\
\hline
\end{tabular}

\begin{tabular}{|c|c|}
\hline Jellemzők & Jellemzők leírása \\
\hline $\begin{array}{l}\text { Alkalmazhatóság lehatárolása } \\
\text { és eredménytermék }\end{array}$ & $\begin{array}{l}\text { Szabványos e-learning tananyagok előállítására alkalmas, Amerikai } \\
\text { Egyesült Államokban fejlesztett, funkciókban gazdag } \\
\text { tananyagfejlesztő szoftver. }\end{array}$ \\
\hline Árazás & $\begin{array}{l}\text { Licenc: } 2595 \text { USD (számos egyéb szolgáltatással együtt, pl.: Camtasia, } \\
\text { Snagit, E-learning Brothers előfizetés stb.) }\end{array}$ \\
\hline Funkcionalitás & $\begin{array}{l}\text { A Lecotra szoftvercsalád része, széles funkcionalitással az alábbi } \\
\text { területeken: széleskörü megoldások reszponzív tartalom készítésére, } \\
\text { horgony funkció, mobil kurzus készítés, média tartalmak } \\
\text { szinkronizációja, Camtasia (videóképrögzítés) integráció, változók } \\
\text { kezelése, státuszállapotok kezelése, oldalelrendezések, kvízek } \\
\text { részletes beállításokkal, előrehaladás jelzők, likert tábla kérdéstípus } \\
\text { kezelése, képek szerkesztése, gombok és effektek beillesztése, listák } \\
\text { kezelése, akadálymentes lehetőségek, széleskörü exportálási } \\
\text { lehetőségek. }\end{array}$ \\
\hline $\begin{array}{l}\text { Kereskedelmi felhasználás } \\
\text { pontos részletei }\end{array}$ & $\begin{array}{l}\text { A szoftverrel készített tananyagok felhasználási joga teljes egészében } \\
\text { a tartalom készítójét illeti meg. Részletek: } \\
\text { https://www.trivantis.com/terms-of-use }\end{array}$ \\
\hline $\begin{array}{l}\text { Terméktámogatás és gyártó } \\
\text { megbízhatósága }\end{array}$ & $\begin{array}{l}\text { A Lectora korábbi verziói már } 1999 \text { óta érhetők el. Az Inpire néven } \\
\text { futó verzió folyamatosan fejlesztett szoftver, széleskörü } \\
\text { terméktámogatással. A Trivantis megbízható gyártónak tekinthető. }\end{array}$ \\
\hline
\end{tabular}




\begin{tabular}{|l|c|c|c|}
\hline $\begin{array}{l}\text { Pontozási } \\
\text { kategóriák }\end{array}$ & $\begin{array}{c}\text { Kategória } \\
\text { jel }\end{array}$ & Pontszámok & \\
\hline $\begin{array}{l}\text { Stabilitás és } \\
\text { megbízhatóság }\end{array}$ & $\mathrm{A}$ & 3,5 & Sugár diagram \\
\hline $\begin{array}{l}\text { Használhatóság és } \\
\text { kinézet }\end{array}$ & $\mathrm{B}$ & 3,5 & 3,5 \\
\hline Ár-érték arány & $\mathrm{C}$ & 3 & $\mathrm{C} ; 3,5$ \\
\hline Testre szabhatóság & $\mathrm{D}$ & 3,5 & \\
\hline $\begin{array}{l}\text { Dokumentáció és } \\
\text { támogatás }\end{array}$ & $\mathrm{E}$ & & \\
\hline Súlyozott pontszám & & & \\
\hline
\end{tabular}

6.10.6.4 iSpring Suite

\begin{tabular}{|l|l|l|l|}
\hline Szoftver gyártója: & Szoftver neve: & Verzió: & Alkalmazási kategória: \\
\hline iSpring & Suite & 9 & Komplex tananyagfejlesztő szoftver \\
\hline
\end{tabular}

\begin{tabular}{|c|c|}
\hline Jellemzők & Jellemzők leírása \\
\hline $\begin{array}{l}\text { Alkalmazhatóság lehatárolása } \\
\text { és eredménytermék }\end{array}$ & $\begin{array}{l}\text { Szabványos e-learning tananyagok elöállítására alkalmas, Microsoft } \\
\text { PowerPoint alkalmazásba beépülő eszköz, amelyet Oroszországban } \\
\text { fejlesztenek a } 2000 \text {-es évek eleje óta. }\end{array}$ \\
\hline Árazás & Öröklicenc: 770 USD \\
\hline Funkcionalitás & $\begin{array}{l}\text { Az iSpring Suite, mint a Microsoft PowerPointba beépülő szerkesztő } \\
\text { szoftver más filozófia mentén müködik, mint egy önálló rendszer, és } \\
\text { funkcionalitás tekintetében is alacsonyabb szinten áll, de } \\
\text { végeredményképpen komplex e-learning tananyagok fejleszthetők } \\
\text { által. Funkcionalitás: PowerPoint konvertálás, videós narráció felvétel, } \\
\text { interaktív feladatok, képernyővideók készítése, dialóguskészítés, } \\
\text { interakciók, LMS exportálási lehetőségek, reszponzív lejátszó, mobil } \\
\text { alkalmazás. }\end{array}$ \\
\hline $\begin{array}{l}\text { Kereskedelmi felhasználás } \\
\text { pontos részletei }\end{array}$ & $\begin{array}{l}\text { A szoftverhez elérhető tartalom könyvtár használata esetében nem } \\
\text { lehet kizárólagos és tovább értékesíthető tartalom felhasználását } \\
\text { nyújtani. } \quad \text { Részletek: https://www.ispringsolutions.com } \\
\text { /legal/ispring_eula.html }\end{array}$ \\
\hline $\begin{array}{l}\text { Terméktámogatás és gyártó } \\
\text { megbízhatósága }\end{array}$ & $\begin{array}{l}\text { A Microsoft PowerPoint átalakítóként indul szoftver a } 2000 \text {-es évek } \\
\text { eleje óta elérhető. A terméktámogatás gyors, de limitált az elérhető } \\
\text { tartalom. Megbízható a szállító. }\end{array}$ \\
\hline
\end{tabular}




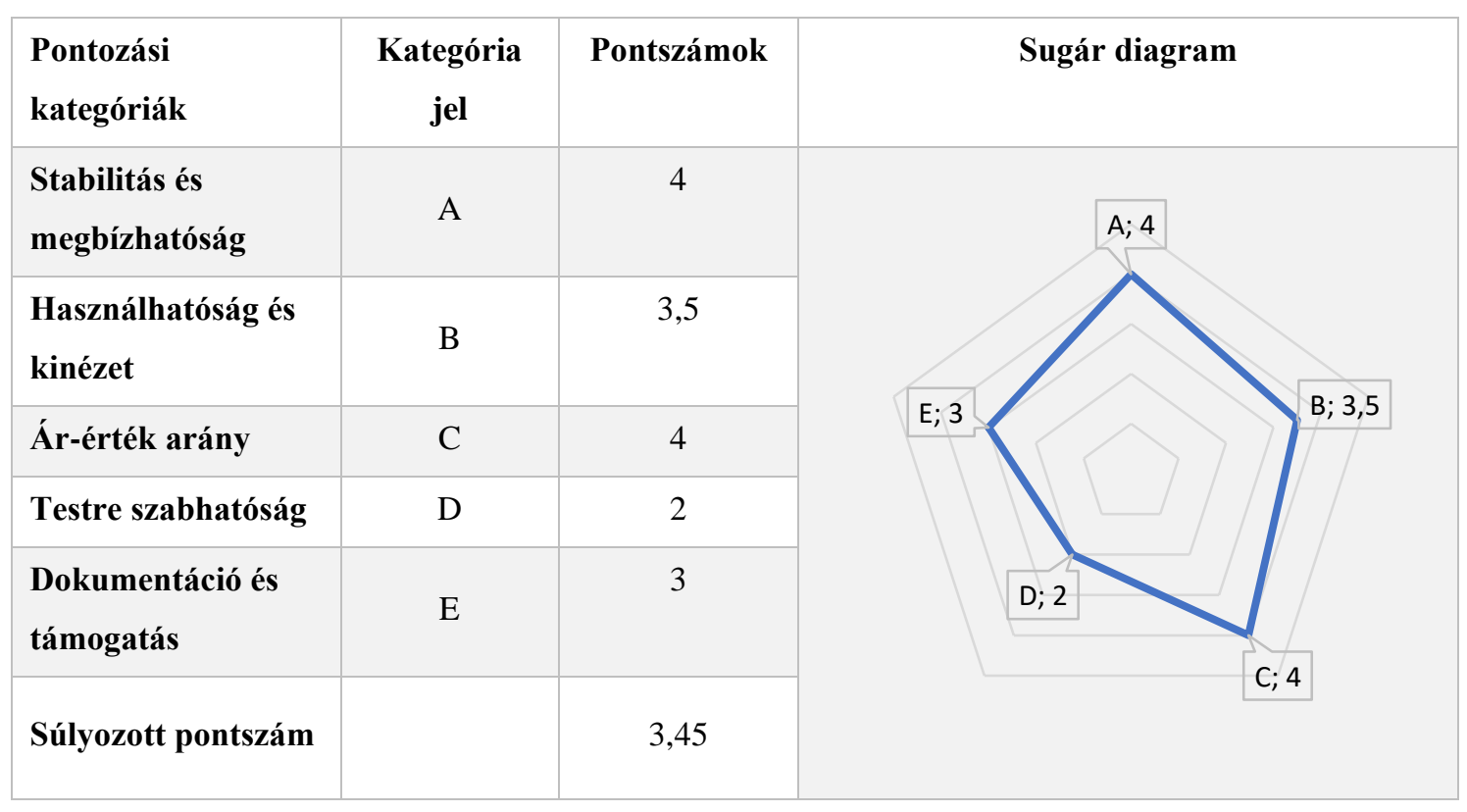

\subsection{Szövegbányászati vizsgálat}

A kérdőív releváns kérdései:

- Q03: „Kérjük az alábbi szempontok alapján értékeld 1-8 ponttal a tananyagot! (1 pont: egyáltalán nem megfelelő; 8 pont: teljes mértékben megfelelő)”

- Q04: „Kérjük amennyiben volt, írd le nekünk milyen technikai problémád volt a tanulás során!"

- Q05: „Összességében hogyan értékeled a tananyagot 1-8 pontig terjedő skálán? (1 pont: egyáltalán nem megfelelő; 8 pont: teljes mértékben megfelelő)"

- Q06: „Kérjük írd le egyéb észrevételeidet, megjegyzéseidet és javaslataidat a tananyaggal kapcsolatban!” 


\section{Publikációs lista}

Nemeslaki A., Samodai D., Labancz G, Gazsi N., Balkányi P., Szabó B. (2008): On-Line Innovációk Adaptációjának Sikertényezői A Magyar Pénzügyi Szektorban Pp. 1-141.

Füleki D., Theiss-Balázs Zs., Balkányi P., Pocsarovszky K. (2008): A Magyar Webes Piac Technológiai Architektúrái. Vezetéstudomány, Vol. 39. No. 12., ISSN: 0133-0179, Pp. 39-50.

Balkányi P., Orbán Zs. (2011): Virtuális Információk A Fizikai Térben: A Kiterjesztett Valóság Jövőképe. Információs Társadalom, Vol. 11. No. 1-4., ISSN: 1587-8694, Pp. 6480 .

Orbán Zs., Balkányi P. (2011): Digitális Tananyagfejlesztési Pályázat A Budapesti Corvinus Egyetemen: Szervezeti És Technológiai Lehetőségek És Korlátaik. Moodlemoot 2011 Konferencia. Szent István Egyetem, Gödöllő, 2011. Június 23-25.

Balkányi P., Nemeslaki A. (2011): A Budapesti Corvinus Egyetem Tudományos Versenyképességének Erösítése: TÁMOP- 4.2.3- 08/1/KMR-2009-0004: Zárótanulmány. Budapesti Corvinus Egyetem. Pp. 1-24., 24 P.,

Balkányi P. (2012): E-Learning Aktorok. In: Raffai, Mária; Dobay, Péter; Pozna, Claudiu Radu (Szerk.) 9. Országos Gazdaságinformatikai Konferencia. Pp. 40-41., 2 P.

Orbán Zs., Balkányi P. (2012): A Kiterjesztett Valóság Fogalma És Alapjai. In: Nemeslaki András. Vállalati Internetstratégia. 271 P. Budapest: Akadémiai Kiadó, 2012. ISBN:978-963-05-9189-8. Pp. 167-189.

Orbán Zs., Balkányi P. (2012): One Way Or Another? - Analyzing The Pragmatic Process Of Implementing An E-Learning Environment With Scientific Methods. Magyarország. CEMS Doctoral Consortium "Methodology és Rigour In Enterprise Networks, Innovation és ICT Research", Budapesti Corvinus Egyetem, Budapest, February 15-17. 2012

Balkányi P., Orbán Zs. (2012): Aktor Alapú Társadalom-Technológia Kapcsolat Vizsgálata Az E-Learning Világában. Gazdasági Élet És Társadalom. (1-2) Pp. 271-287. (2012). ISSN 2060-7466

Balkányi P., Orbán Zs. (2013): Social Constructivism In Public Administration IT Development: Case Analysis Of An E-Learning Project. In: Tarczali Tünde (Szerk.). 4th Annual Conference Of The European Decision Sciences Institute (EDSI). Konferencia Helye, Ideje: Budapest, Magyarország, 2013.06.16-2013.06.19.Pp. 1-8.

Orbán Zs., Balkányi P. (2015): E-Learning Tananyagok Fejlesztése A Közigazgatásban. Pro Publico Bono: Magyar Közigazgatás, No. 4., ISSN: 2063-9058, Pp. 100-111.

Orbán Zs., Balkányi P. (2015): Kihívások És Sikerek A Videós Tananyagok Tömeges Alkalmazásában. In Ujhelyi, A., Lévai, D. (Szerk.) VII. Oktatás-Informatikai Konferencia, ISBN: 978-963-284-598-2, Pp. 325-340., ELTE PPK Neveléstudományi Intézet, Budapest 
Balkányi P. (2015): Kvíz Alapú Tanulástámogató Mobilalkalmazás Fejlesztése. In Námesztovszki, Zs., Vinkó, A. (Szerk.) XXI. Multimédia Az Oktatásban És II. IKT Az Oktatásban Konferencia, ISBN: 978-86-87095-54-0, Pp. 46-51., Újvidéki Egyetem Magyar Tannyelvü Tanítóképző Kar, Szabadka

Orbán Zs., Nagy V., Balkányi P. (2015): E-Learning Based Education és E-Skill Development At The Public Service. In Balthasar, A., Golob, B., Hansen, H., Kőnig, B., Müller-Török, R., Prosser, A. (Szerk.) Central és Eastern European E|Dem és E|Gov Days 2015: Time For A European Internet? ISBN: 978-2-85403-308-0, Pp.579-594., Andrássy Gyula Budapesti Német Nyelvű Egyetem, Budapest

Balkányi P., Orbán Zs., Nagy V. (2015): The Role Of The Social Media In Civil Initiatives. In Balthasar, A., Golob, B., Hansen, H., Kőnig, B., Müller-Török, R., Prosser, A. (Szerk.) Central és Eastern European E|Dem és E|Gov Days 2015: Time For A European Internet? ISBN: 978-2-85403-308-0, Pp. 465-478., Andrássy Gyula Budapesti Német Nyelvü Egyetem, Budapest

Balkányi P., Orbán Zs., Nagy V. (2016): Nagyvállalati E-Learning - A Képzésmenedzsmenttől Az Infotainment-Ig. In Hülber, L. (Szerk.) I. Oktatásszervezési És Oktatásinformatikai Konferencia, ISBN: 978-615-5621-14-7, Pp.48., Eszterházy Károly Egyetem, Eger

Balkányi P., Mongyi Zs. (2018): Moodle bevezetés nagyvállalati környezetben. MoodleMoot 2018 konferencia. Debreceni Egyetem. 2018. október 4.

Balkányi P. (2019): Szövegegyezőségvizsgálat és a Moodle - Tapasztalatok a Budapesti Corvinus Egyetemröl. MoodleMoot 2019 konferencia. Debreceni Egyetem. 2019. június 24.

Balkányi P., Orbán Zs. (2019): Institutional Adoption of a Learning Management System in Higher Education: A Case Study of the Corvinus University in Budapest. Academic és Applied Research in Public Management Science, ISSN: 2498-5392 - Befogadott közlemény 